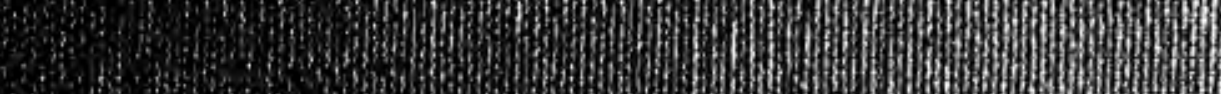

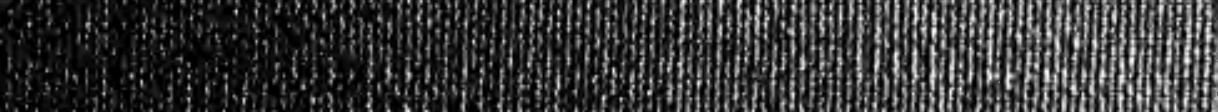
S. (1)

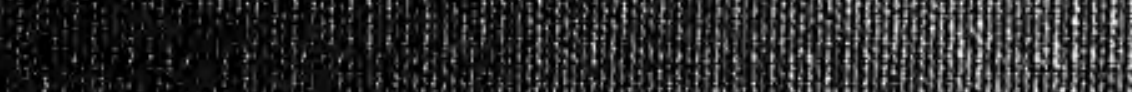

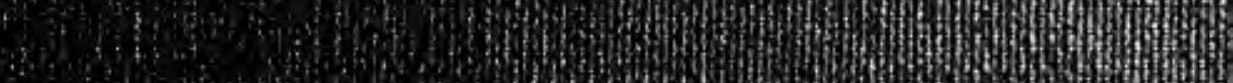

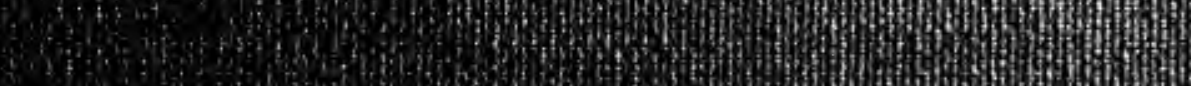

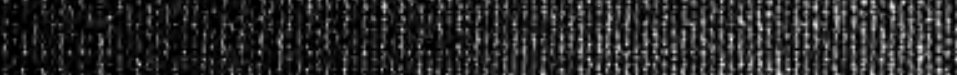

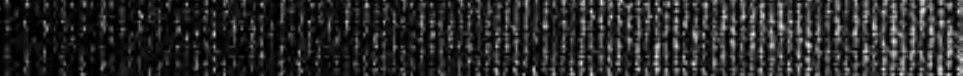
020 s. tons

(3)

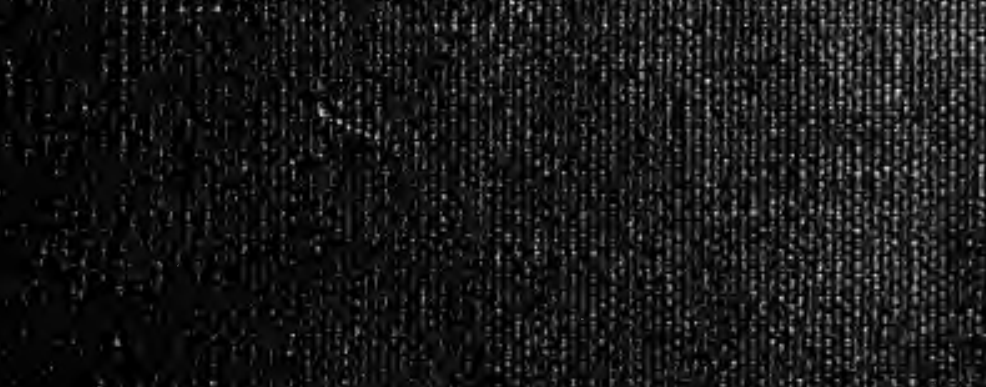

.

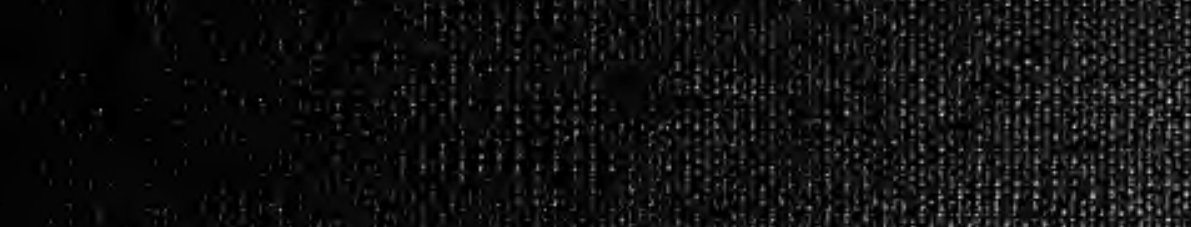

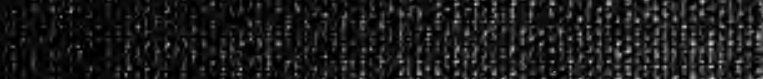
W

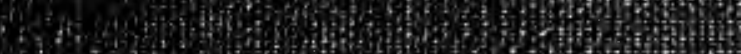

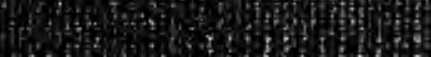
W. ${ }^{2}$ (6) mons 3.13 2. 29 s.

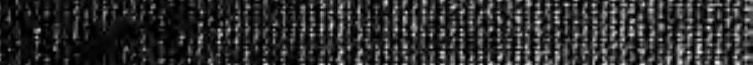

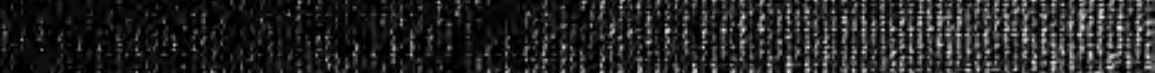

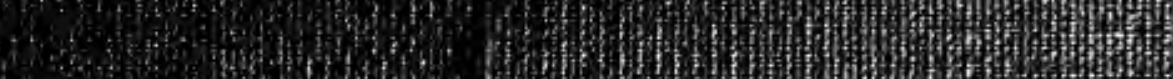

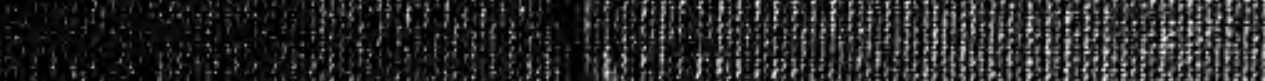
2. 4. (150) 3.

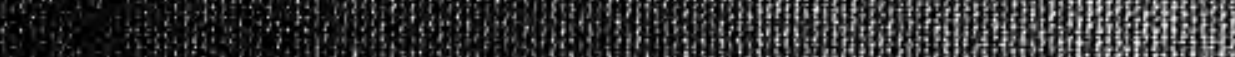

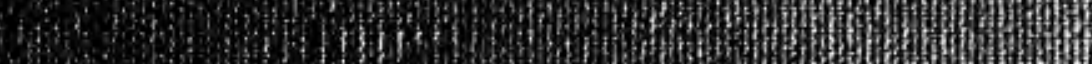

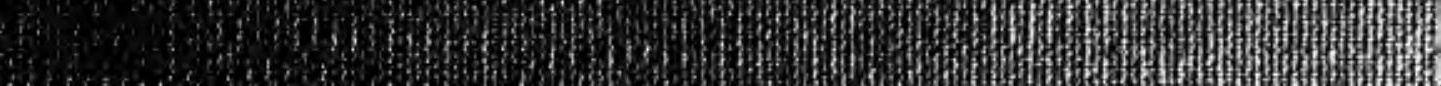







$\Lambda N$

\section{AUTHENTIC ACCOUNT}

OF

\section{AN EMBASSY}

F ROM

\section{THE KING OF GREAT BRITAIN TO THE EMPEROR OF CHINA;}

INCLUDING

CURSORY OBSERVATIONS MADE, AND INFORMATION OBTAINED, IN TRAVELLING THROUGH THAT ANCIENT EMPIRE, AND A SMALL PART OF CHINESE TARTARY.

TOGETHER WITH A RELATION OF

\section{THE VOYAGE UNDERTAKEN ON THE OCCASION}

BY HIS MAJESTY'S SHIP THE LION, AND THE SHIP HINDOSTAN, IN THE EAST

INDIA COMPANY'S SERVICE, TO THE YELLOW SEA, AND GULF OF PEKIN;

AS WELL AS OF THEIR RETURN TO EUROPE;

WTH

Yotiges OF tHe SEVERAL PIAGES WHERE THEY STOPPED IN THEIR WAY OUT AND HOME;

BEING THE ISLANDS OF MADEIRA, TENFRIFFE, AND ST.JAGO; THE PORT OF RIO DF.

JANEIRO IN SOUTII AMERICA; THE ISIANDS OF ST. IIELENA, TRISTAN

D'ACUNIIA, AND AMSTERDAM; TIE COAST OF JAYA, AND SUMATRA,

TIE NANKA ISLES, TULO CONDORE, AND COCHIN-CHINA.

TAKEN CHIEFLY FROM THE PAPERS OF

His Excellency the EARL OF MACARTNEY, Knight of the Bath, His Majesty's

Embassador Extraordinary and Plenipotentiary to the Emperor of China; Sir ERASMUS GOWER,

Commander of the Expedition, and of other Gentlemen in the several departments of the Embassy.

\section{BY SIR GEORGE STAUNTON, BIRONET,}

Honorary Doctor of Laws of the University of Oxford, Fellow of the Royal Society of London, his Majesty": Secretary of Embassy to the Emperor of China, and Minister Plenipotentiary in the absence of the Embassador.

In Two Volumes, with Engravings; beside a Folio Volume of Plates.

VOL.I.

LONDON :

PRINTEN BY W. BULMER AND CO.

FOR C. NICOL, BOOKSELLER TO HIS MAJESTY, P ILI-MAL.

MDCCXCYII. 


\section{ADVERTISEMENT.}

THE following sheets were composed in obedience to the prublic voice. The circumstances that led to an Embassy to China, the preparations that were made, the route that was fursued, the comntries that were visited, the transactions that took place, all excited a curiosity, which the Minister, who originated the measure, was well disposed to gratify. And it was thought most likely to be satisfactory that the materials for this purpose should be entrusted to a person who had been himself acquainted, from the beginning, with evory particular of the expedition; and who, afterwards, was present at every thing that passed during the progress of it. He has endeavoured to acquit himself of this duty, with all the diligence that the ill health under which he laboured would allow, in the expectation that, from the necessary delay of the Engravings, the Public would not have to wait for his part of the performance; and in the hope, likewise, that his efforts would be received with greater allowance, than if he had come forward from the suggestions of his own mind, and with a conscionsness of talent and literary attcinments, which might enable him to defy the severity of criticism. 



\section{TABLE OF CONTENTS}

OF THL

FIRST VOLUME.

\section{CHAPTER 1.}

OCCASION OF THE LMBASSY.

InTroduction.-Privileges granted by the Chinese government to the Portugueae, who were the first Europeans that visited China by sea.-Favour sheron to the Dutch, in consequence of certain services rendered by them.-Missionaries for the propagation of Christianity in China promote the interest of their respective conntries-general character of the missionaries, - First attempt of the Englisb to establisb a commercial intercourse witb the Clinese at Canton, through the means of the Portugueze at Macao, as taken from a manuscript account of the expedition-bow Engtish treated by the Portugueze-quarrels with the Chinese government-bostile attacks-unfavourable impression of the Englisb in the minds of the Cbinese-ostensible motives of the latter for permitting foreign nations to trade to Canton-their indifference as foreign trade-grievances suffered by Europeans, and more particularly by the English, at Canton-Sucb grievances unknown to the Emporornecessity of representing them to bim-first suggestion of an embassystrengthened by a consideration of the relative situation of Cbina and neighbouring possessions of the English in Hindostan-additional motires.-Fatal acident at Canton-misrepresented at the court of Pekin - critical state of trade to Canton-its importance-account of the first introduction of tea in Europe-rapid increase of its consumption in VOL. I. 
England.-Possibility of securing an intimate connection with the Cbinese empire-adrantages of such a connection-plan of the present Embussy-cautions to be observed in the choice of an embassador.

page 1 to 29 .

\section{CHAPTER II.}

PREPARATIONS FOR THE EMBASSY.

Thoughts on patronage-safely exercised in favour of popular charuters-instanced in the case of Lord Macartney-bis conduct in former siluations-appointed Embassador to China.-All the persons composing the Embassy recommended by bim-names, qualifications, and stations of most of them-diffculty of filling up the appointment of interpreter-two Chinese qualified for that purpose found at Naples, and brought to England.-Interpreters aseful in the selection of presents for the Emperor-nature of them.-Intention of the Embassy announced in a letter from the Cbairman of the East India Company, sent by Commissioners to Canton-extract of that letter-false alarm taken at the secret rien's of the Embassy byone of the diplomatic corps.Real intent of sucb mission, as appears in bis Majesty's private instructi ins to bis Embassador-also in bis letter to the Emperor of China.Discretionary powers gizen to the Embassador to visit otber countries in the East.-All the persons belonging to the Embassy meet at Portsmoutb in readiness to cmbark-tbeir general disposition.

page $3^{\circ}$ to $5^{2}$.

\section{(HAPTER HI.}

PASSAGE TO MAIEIRA. NOTICES OF THIT ISL IXND.

Slips sail from P' rtsmoulb-Yackatl tender separaled from themare forced to anchor in Torbay.-Conveniences experienced in large ships-reflections on the situation of passengers at sea-sea-sickness- 
midshipmen.-Ships depart from Torbay-nautiol remarks.-Arricial and reception at Madeira-road and andworage of Finabal - cursory remarks upon the island-story of an Englishman, the supposed discoverer of Madeira-survey of the island by Mr. Yohnstoneindolence of the stronger, and industry of tbe weaker sex-agriculture-produce of Madeira-chief irade in bands of the Englisl,-tbeir bospitality-introduce freemasonry at Funcbal-tbat fraternity persecuted till relieved by an edict from Lisbon-influence of the clerry wn the decline-population of the island-diseases most frequent-exarsion to the crater of an extinct volcano-geological remarks.-Defences of Madeira-its military establishment._-Sbips depart from Fumchal.

page 53 to 85 .

\section{CHAPTER IV.}

PASSAGE TO TENERIFEE; TO ST. JAGO. NOTICES OF THOSE ISI.ANDS.

Conjectures relative to the origin of islands lying off the coast of Africa-currents running between them.-Different appearances of the peak of Teneriffe-coast of tbat island.-Road of Sant a Cruz.-Peril to roluich the gallantry of Admiral Blake must bave exposed him there in the last century-general vicw of Santa Crũ and neigbbonrbood-conversation between a native of the island and a gentleman of the Embassy.-Excursion into the country-inland capital-females imprisoned there.-Excursion continued to the town of Oratava-General use of British manufactures.-Fourney towards the peak-Tempestuous weatber-return witbout attaining the summit-some account of the town and port of Oratava. - Narrative of $M r$. 'Fobnstone's successful ascent to the peak. Inbabitants of the island supplied witb ice tbrougbout the yearfrom neigbbourbood of tbe peak.-Religious labbits of the people.-Escape of a young lady from a convent during the preparations for ber taking the veil. Wealtb of the bisbop of the Canary island: 
-his application of it-character.-Commerce of the Canaries.-Rerenue of the crown-monopolies. - Volcanic appearances of Teneriffeextent-climate.-Descendants of original inbabitunts, veryfew-c.rises of their decrease.-Canary birds-population of the several Canary islands.-Route to the Cape de Vorde islands. - Arrival at Port Praya in the island of St. Yago-distress of an Englisb sailur found upon the beacb-his account of the avretched state of the island frum drought-general view of the port and neigbbourbood-vegetation - tree of vast size. - Miserable condition of the governor, inbabitants, and cattle, in all the Cape de Verde islands-prescut reduced population-same acconnt of barbours in these islands.-Geological remarks in the island of St. Yago-town of St. Yago in ruins.-Fessets in Port Praya.-Scene of action between Admiral Suffren and Commodore Gobnstone.-Instance of political morality.-Monopoly of slave trade in St. Yago-little whlue of money there.-Ships sail from Port Praya.

page 86 to 141 .

\section{CHAPTER V.}

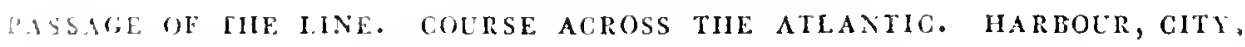
ANI COUNTRY OF RIO DE JANEIRO.

Observations on the relative position of the African and American continent.-Precantins observed by commander of the Lim for the preservation of bis crew.-Reflections on origin of ceremony in crossing the Line-bow performed.-Remarks on winds and currents in crossing the Atlantic.-Island of Frio.-Directions for entering into, and observations on, barbour of Rio de Yaneiro-general view of city and barbour of Rio-shops full of Britisb manufactures-canse of unbealtbiness of Rio-gay disposition of its inbabitants-external ceremonic's of religion observed-dress, manners, customs, - public walksbotanic garden-cochineal insect, and plant on which it feeds, with. 
manner of preparing the dye-manufactory for whale oil-slave trade - situation and disposition of thse imported into Rio.-Character of original inbabitants of the Brasils-face of the country bebind Rio, and its produce.-Valley of Tijouca._Division of the Bra ills into several governments - condition of each-productions-grievances of the settlers - conspiracyformed bysome of the principal among them-alteration in their disposition-views of independence.-False policy of Portugueze government towards the Brasils. - Defences and military establishment of Rio-attention of viceroy to the Embassador-imminent danger of the Lion in sailing out of the barbour.-Departure. page 143 to 191.

\section{CHAPTER VI.}

PASSAGE TO THE SOUTHERN PART OF THE ATLANTIC, AND OF THE INDIAN,

OCEAN. YIEW OF THE ISLANDS OF TRISTIN D'ACUNIA IN TIE FORMER,

AND OF THOSE OF ST. PAUL AND AMSTERDAM IN TUIE LATTER.

Uniformity of the zeinds witbin and near the tropics-preparations made against bad rueather apprebended beyond them.-Uncommon effects of sea-sickness on one gentleman on board the Lion.-Languror bow avoided by passengers at sea-accupations.-Distinctions observed in ships of war. - Arrival at, and view of, islands of Tristan d'Acunbapart, probably, of a chain of subaqneous mountains.-Plans formerly in contemplation for forming a settlement on Tristan d'Acunba.-Ships proceed from thence to the eastivard. - Currents near the Cape of Good Hupe-bard gale of wind.-Arrival at the islands of St. Paul and Amsterdam-men unexpectedly perieived on the latter.-Narrative of Perron and bis companions-tbeir occupation there-abundance of seals and sea lions.-Dimensions of a cove opposite the anchorageboiling springs round its sides-a great crater-wole island volcanic-part still in a state of inflammation-extent of the island-fish and fowl abundant.-Perron conducts some of the gentlemen round 
the island-in the mean time is despoiled of part of lis property.Sbips depart from island of Amsterdam.

page 191 to 227 .

\section{CHAPTER VII.}

LNTR.ANGE INTO THE STRAITS OF SUND.. VISIT TO DATAVIA AND BANTAM

I. THE ISLAND OF JAVA. VIEW OF TIE SOUTHERA EXTREMITY OE THE

ISLANO OF SUMATRA. IASSAGE THROUGH TIIE STRAITS OF BANKA TO

PLIG-CONDORE.

Lion and Hind stan separale in altempting to discozer vessels bound for Europe.-Symptoms of scuroy make their appearance in the crews - pains taken against it._. Tico of islands on entering into the straits of Sunda.-Different parts of the earlb differently produced.-Gradations in the seale of animated nature.-Aquatic animals-marine substances.-Sbips proced to Batavia-reception of Embassador there-dispatches from Conmissioners at Canton, favourable to the views of the Embassy-contents communicated to the Dutch government-entertainment given by Governor General-beantiful appearance of country immediately about Batavia-yet extremely unbealtby to Europeans-saying on the occasion-diseases to wbicb Europeans are subject there-state of the atmosphere-little diminution of the beat at night-uniformity of temperature favourable to the preservation of the teeth-singular custom of Yavanese with regard to theirs-difficulty of filling employments by proper persons-necessity of procuring military recruits from Germany-tbeir miserable condition at Batavia-defence and military establisbment there-commerce of that place with Cbina-climate not bostile 10 Clinese settlers -industry and moderation of the latter, contrasted with indolent and luxurious liwes of the Dutch aho reside there-bow the latter spend their time-manners, dress, and disposition of the Dutch ladies at Batavia-bow power of the Datch maintained. - State of the native 
Gavanese-of imported slaves-these clbiefly females-Emperor of Fava's female military guard-other sorereigns in . Fara-passion of Favanese for gaming - fatal consequences-running a muck.-Revolt of the Chinese settlers against the Dutch governinent-many of them put to death-apology made to the Emperor of China-remarkable reply of bis Imperial Majesty-Cbinese at Batavia retain their nutive customs-instanced in the veneration for their ancestors, and manner of burying their dead-utility of Cbinese settlers at Batavia-Descendants of Portugue a in Batavia retain their language, but cbange their religion for that of Calvin.-Dutch management of the spice trade.-Description of the nutmegplant-clone-cimamon-pepperarecanut-report of Upas, or poison tree-Mangrosteen, and otber fruits. -River of Batavia abounding in erocodiles-superstitions notions of the Favanese concerning them-similar to those of the Egyptiansculture about Batavia-description of the town-population of Batavia, and of the districts round it belonging to the Dutch.-Slips sail from Bataria.-Lion struck upon an unknown rock-necessity of purchasing the Clarence as a tender.-On return to straits of Sunda, unexpectedly find there the Fackall brig-some of the gentlemen survey the mouth of the straits-ascertain longitude of several places-in one place discover caves filled witb the swallow nests, higbly prized in Cbina-Yavonese method of taking those nests.-Description of Malays on the coasts of Yava and Sumatra-instance of apparent civilization in these people, follow'ed by another of savage inhumanityvarious remarks in the straits of Sunda-iisit to Bantam-enteriainments of the Gavanese-luxuriance of regetation in Fava.-Squadron sails for the straits of Banca.-Floating islands.-Mines of tin in the island of Banca, profitable to Dutch East Intia Company-Arrival at Pulo-condore-bay on eastern side described-latitude and longitude of the island ascertained by observation-inbabiants-dread of the squadron-desert their bouses-leave a letter in one of them for 
the squadron-answer from the squadron, with a present left in the same place-bad weather-danger in a boat-accident on board the Hindostan-departure of the squadron.

page 298 to 317 .

\section{CHAPTER VII.}

COCHIN-GHINA.

Sickly state of the squadron.-Turon bay in Cocbin-china a desirable place to refresb at-route thither-pilot taken out of a boat upon the coast of Cocbin-cbina-bis astonisbment and alarms-directions for entering into Turon barbour-zobere squadron anchors-suspicion of bostile intentions on the part of the squadron-late revolutions in Cocbin-cbina-arrival of a person of rank from the sovereign of the neigbburing country, with presents to the Embassador-harbour and town of Turon-dimner given by the Governor of the place-agility of the natives-sbuttlecock played with the feet-ingenuity of natives exemplified-method of purifying sugar-transfer of females on easy terms-oppressive conduct of the upper, bumiliating situation of the lower ranks-music cultivated in Cocbin-cbina-entertainment and play given to the Embassador-British manufactures in use among the natives-bow supplied-military establishment of the countryelephants trained for war-killed for food-precious metuls found in the mountains of Cocbin-cbina-other commodities-seldom brought down to the plains since the troubles-inhabit ants of the former a different race from the latter-of these the diet-dress-industry-corrupt judicature.-Curious insect found near Turon-description, and geometrical admeasurement, of that barbour-climate-periodical inundations-danger of trading to coast of Cocbin-china witbout a protecting settlement-instanced in the narrow escape of a vessel sent thither from Bengal.-Description of the island of Callao.-Adranlages of a settlement at Turon.-Deatb of the purser of the Lion- 
master of the Lion detained for some days by the natives in an attempt to explore some part of the country-lics account of wabat be saw and suffered.-Extent of Cocbin-cbinese dominions.-Departure of the squadron announced to the sovereign of Turon-further presents from. bim._-Squadron sails. page 318 to 382

\section{CHAPTER IX.}

PASSAGE TO THE LADRONE ISLANDS NEAR MAOAO; AND TIIINGL TO CIIU-SAN. TRANSACTIONS AND OBSERVATHONS TIHERE.

Conjectures on beigbt and irregularity of tides in gulf of Tung-quin.Arrival at Ladrone islands-some account of them.-Brigs ordered to Macao.-One of the Chinese interpreters withdraws from the service of the Embassy-bis conduct contrasted with that of bis colle ague. Information obtained at Macao from the Commissioners, relative to the impression made on the officers of government at Canton, on the Embassy being announced to them-their conduct in consequencetheir eagerness to obtain a list of the presents-to find out the view's of the Embassy.-Two Cbinese merchants ordered from Canton to Pekin to serve as interpreters-bow and why prevented.-European missionaries formerly appointed to that office by the Cbinese conrtnatives now preferred.-Squadron in proceeding tbrough the straits of Formosa meets with mucb bad weather-reasons for supposing such weather to be frequent there.-Reacb the Quee-san islands-multitude of Chinese vesselsunder sail-former chart of Chu-san islands correctedClarence dispatched to town of Chu-san-general description of Cbusan islands. -Visit to island of Lowang. - Cbu-san barbour.-Fisit to governor of Chu-san-to neiglbbouring city of Ting-bai-its streeisbouses-markets-dress of the people-feet of the women crampedconjectures on the origin of such a custom.-Why Europeans more offected by bot weatber than Chinese.-Governors ball of andience.VOL. 1 . 
number and variety of bandsome lantborns-large lantborns entirely made of born-art of making sucb, - dwarf trees in ball of audienceArt of dwarfing trees.-Pilots procured to conduct the squadron through the Yellow sea.-Governor's visit to the Clarence-Cbinese physician's attendance on a sick person on board-mode of feeling the pulse.-Departure of Clarence from Chu-san barbour._-Alarming ishirlpool.-Clarence joins the ships.-Embassador declines an invitation to go ashore:-Squadron sets sail.

page 383 to 437 .

\section{CHAPTER X.}

NAYIGATION TIROUGH THE YELLOW SEA. MMBASSADOR'S ENTRANGE INTO THE RIVER LEADING TO TIEN-SING.

Extent of the Chinese coast.-Boundaries of the Yellow sea.-Conduct of Cbinese pilots.-Low state of navigation among the Cbinese,canses there of.-Chinese compass described -its advantages.-Opinions of the Cbinese regarding magnetic attraction.-Reflections of Canngshee, Emperor of China.-Progress of the squadron tbrough the rellow sea-meets the Endeavour brig.-Account of Mr. MrCluer's stay at one of the Pelew islands-disposition of the people there-of those of New Guinea.-Continuance of the squadron's navigation.Conjectures on the formation of a large island near the east coast of Cbina.-Several islands discovered through the Tellow sea.-Peninsula of Shan-tung-bays upon its nortbern shore.-City and road of Ten-cboo-foo.-Instance of Chinese manners.-Proclamation of the Embassador-its effect.-Strait of Mi-a-tau-extraordinary direction of the tides-canses thereof.-Captain Campbell's report of the bay of Mi-a-tau.-Squadron enters the gulf of Pekin.-Arrives outside the bar before the river Pei-bo.- Yackall dispatched in quest of a promised barbour - none found-reasons why no good burbour in that gulf.-Mr. Hither's account of the shore.-Arrival of two manda- 
rines on board the Lion-description of them.-Presents of provisions sent for the squadron.-Peculiar difficulty for foreigners to pronounce or understand the Chinese language.-Description of some of the presents intended for the Emperor.-Presents transbipped into Cbinese vessels, in order to cross the bar-particulars concerningthose vessels.Instructions to Sir Erasmus Gower, during the Embassador's stay on shore.-Parting of bis Excellency and suite from the sbips-crossing the bar-entrance into the river Pei-bo.-Arrival at Tacoo.

page $43^{8}$ to 518 . 



\title{
A LIST OF THE PLATES
}

\author{
CONTAINED IN THE FOLIO VOLUME.
}

No.I. A general chart, on Mercator's projection, of the track of the ships from England to the gulf of Pe-che-lee, or Pekin, and of their return to England; containing also the limits of the Chinese empire, as extended by the conquests of the present Emperor Chien-lung.

II. A view of the eastern side of the island of Amsterdam, in the Indian ocean, taken from the anchorage about a mile distant from the shore; also sketches of the island, and a plan of the great crater. This island, of volcanic origin, is still in a state of inflammation. It lies in latitude thirty-eight degrees forty-two minutes south, and longitude seventy-six degrees fifty-four minutes east of Greenwich.

III. A chart of part of the coast of Cochin-china, including Turon harbour, and the island of Callao; to which is added, a view of the cntrance into Turon bay, the southern peak of the peninsula Tien-cha, bearing west by north, distant ten miles.

On approacling this peninsula from the southward or westward, the entrance in:o the harbour appears to lie between it and a curious group of marble rocks, which in fact are connected by a very low and narrow isthmus, not visible from the deck at the above distance of ten miles. The entrance is round the northern point of the peninsula.

IV. A chart on Mercator's projection, containing the track and sound- 
ings of the Lion, Hindostan, and tenders, from Turon bay in Cochinchina to the mouth of the Pei-ho river in the gulf of Pe-che-lee, or Pekin.

As a great part of this track, namely, from the Chu-san islands to the western extremity of the gulf of Pe-che-lee, or Pekin, was never before navigated by European vessels, at least no accounts are extant of such navigation, particular pains were in this instance taken to ascertain the squadron's exact situation at noon of each day, as to latitude by meridional, or, when the weather was unfavourable for these, by double altitudes; and as to longitude, either by the mean of several time-keepers, whose rate of going had been determined near Nicholas point on the island of Java; or by observations of the distance of the moon's limb from the sun or fixed stars, taken by several persons at the same time, whenever the weather and situation of the objects would admit of it. Several sets of these being taken directly opposite, and in sight of, the bold projecting promontory of Shan-tung, and also when the squadron was afterwards at anchor near the mouth of the Pei-ho in the gull of Pekin, it may be presumed that these situations, as well as indeed the whole track, are laid down with a tolerable degree of exactness.

V. A chart of several clusters of islands lying on the eastern coast of China, usually called the Chu-sin islands, with the track of the Glarence from the southernmost group, called the Quee-sans, to the luarbour of Chutsan. This plate contains also a sketch of the harbour of Chu-san, taken with the compass from the ancliorage of the Clarence, and the appearance of the surrounding lands, as seen from the same spot.

Or these islands a chart had formerly been published; but the situation of the Holdemess rock, tho taken exactly from the journal of the ship of that name, is very erroneonsly marked upon it; and it is of ma. terial consequence to know its exact position; nor is any notice taken in that chart of the rock on which the Hindostan struck; nor the proper 
track laid down, thro the very intricate passages amongst those numerous islands. It was therefore thought that a now chart, with these and other alterations and additions, might not be useless to the future navi. gator.

VI. A sketch by compass of the coast of the promontory of Shan-tung, with the track of the slips, and the soundings, from the place of first making the land to the strait of Mi-a-tau.

From the great extension of this promontory, or bold point of land into the Yellow sea towards the kingdom of Corea, beyond the rest of the Chinese coast, it was conceived there might be a considerable degrce of danger and difficulty in sailing round it into the gull of Pckin. The squadron, however, standing well in towards the coast, doubled the promontory in sight of the land the greatest part of the way, which furnished an excellent opportunity of marking down the different points, and the depth of water. It was of importance to have determined that there was no harbour fit for large ships in the strait, or among the islands of Mi-a-tau, as had been supposed from the information of Chinese pilots, and to have discovered an excellent bay on the northern coast of the promontury of Shan-tung, where none had been expected. This bay, and the whole coast, is laid down with as great accuracy as circumstances would allow.

VII. Views of the land which forms the eastem extremity of the pro. montory of Shan-tung.

This land, or an island near it, being the first likely to be seen by ships sailing thro the Yellow sea, and bound for the gulf of Pekin; it was thought expedient to ascertain the exact position of the same, and to give names to such parts as were not so distinguished in the charts of the Chinese empire. This plate contains also a view of the coast near, and part of the city wall of Ten-choo-foo, taken from the anchorage of the Hindostan, in the strait of Mi-a-tau. 
VIII. A sketch of the Pei-ho, or White river, from its entrance into the gulf of Pekin to the city of Ten-choo-foo, in which are marked down the cities, towns, principal villages, and military posts situated upon its banks. This plate contains also a sketch of the road from Pekin to Zhe-lool, in Chinese Tartary; in which are situated, at certain distances, six different palaces and gardens for the accommodation of the Emperor of China, when travelling between those two places.

IX. A sketch of a journey from Zhe-hol in Tartary, by land, to Pekin, and from thence by water to Hang-choo-foo, in China.

X. A sketch of a journey from Hang-choo-foo to Quang-choo-ioo, or Canton, in China.

These two plates comprehend all that extent of country lying between the town of Zhe-hol, in Chinese Tartary and the city of Canton, at the southern extremity of the enıpire, a distance not less than fifteen hundred miles. The rivers and canals that open a direct communication between the capital and the port of Canton; all the cities of the first, second, and third order, with many considerable towns and villages, situated upon the banks of those canals and rivers; the general surfaces, as well as produce, of the different parts of the country that occurred in this route; with the temperaturc, as shewn by Fahrenheit's thermometer, at the time they were passed, arc marked down on these sketches.

XI. A plan of the city and harbour of Macao, a colony of the Portugueze, situated at the southern extremity of the Chinese empire; containing references to all the forts, colleges, convents, and other public buildings and places of note; and also the depth of water, and nature of the ground, in every part of the inncr harbour, as well as in the space between the peninsuld and the northem entrance into the Typa; taken fiom an accurate surrey made by a genteman long resident on the spot. 
XII. A leaf of the cactus opuntia, or prickly pear, with the cochineal insects that feed upon it. The male and female of those insects in the different stages of their existence and growth; and a fly, lound in uumbers upon the same plant, and supposed to feed upon the cochineal insect; accurately delineated from nature, at Rio de Janeiro, in Soutl America.

XIII. The fire-backed pheasant of Java, a new species thus described by Doctor Shaw. Black pheasant with a steel-blue gloss; the sides of the body rufous; the lower part of the back fiery-ferruginous; the tail rounded; the two middle feathers pale yellow-brown.

XIV. View of a village on the borders of Turon bay, in Cochin. china, with a group of the natives amusing themselves with a game of shuttlecock, which they strike with the sides and soles of their feet instead of battledores.

XV. View in Turon bay, taken from the point of a small island, on which a few of the natives are assembling for the purpose of making an offering to the deity in a humble temple, consisting only of a few poles that support a thatched roof. The boat approaching the island, with the rowers standing, is one belonging to the governor of the district. The Lion and Hindostan are seen at anchor in the bay.

XVI. A mandarine, or magistrate of Turon, attended by his pipebearer. These, with few variations, are the usual dresses worn by the natives of Cochin-china, and differ little in their general appearance from those of China.

XVII. A Chinese military post. Military posts of a similar kind, but various in their form and plan of construction occur at certain distances, greater or less as may be deemed necessary, for the internal peace of the vol.I. 
empire, for the protection of travellers on the public roads, and of ressels on canals and rivers. Each contains in general from six to twelve men, who are drawn out in their best military attire, as represented in the plate, whenever a person of consequence passes by. Their dress is then taken off, and haid "p carefully till a future occasion. The soldier on the top of the fort gives the signal, by striking a brazen instrument, called by the Chinese, Loo, of the approach of the person to be saluted, that the men may be prepared. Near to the military post there is frequently a small temple, as at the end of the wall in the present plate, in which is contained, among other deities, the god of was.

XYIII. Chinese military drawn out in compliment to the Embassador, and falling on their knees, to receive him, where he is supposed to be about to land. Beside the military posts, mentioned in the last number, a considerable establishment of troops is kept up in every city of the empire. When the walls of any of these were approached by the barges of the Embassy, about three hundred soldiers were drawn up along the bank of the river or canal, in a single rank, the officer's tent was pitched, the military band began to play, and a salute of three small petards, placed perpendicularly in the ground, was fired off when the barge of the Embassador, or those which carried Chinese men of rank, passed before the officer's tent.

XIX. Instruments of war used by the Chinese.

These may serve" as a specimen of a few amongst the many binds in use among the militaly of China.

XX. Vicw of one of the westem gates of the city of Pekin.

The nine gates of this city resemble cach other res nearly: except that the projecting wall in some is square, in others circular. The two lofty buildings are pretty unch the same in all. The ditch, which in liact is a framele ol a siver, rums alderg the sonthern and western walls only of the 
city, and on these sides divides it from the suburbs, which are very considerable at each gate, and a bridge of communication at those by which the river passes. The small two-wheeled carriage crossing the bridge, and drawn by one horse, is of the sane kind as those which stand for hire in the streets of Pekin, as do hackney coaches in England, and is the only kind of carriage used in the comntry.

XXI. Plan of the hall of audicnce, and of the three courts leading to it, at the palace of Yuen-men-ynen, in the neighbourhood of Pekin, with the arrangement of some of the presents, as they were placed for the Emperor's inspection.

XXII. A view of the front of the hall of audience at the palace of Yuen-men-yuen. This plate will serve to convey a general idea of the superior kind of buildings in China, which are always erected on platforms of stone-work, and their large projecting roofs are supported on columms of wood.

XXIII. Plans, sections, and elevations of the great wall of China, and of some of the towers near the pass of Con-pe-koo. The wall appears to be generally of an uniform construction and dimensions throughout, but the towers differ in their plan and strength, according to their situation; those erected across a pass, or upon a river, so as to be easily approached by an enemy, are the lighest and strongest. Some consist of one, and others of two stories, beside the platform on which the parapet stands and that part which is below the terrace of the wall, this being either of solid masonry or brick-work, or retaining walls only, with the intermediate space filled with earth.

XXIV. A view of part of the great wall of China, called by the natives Van-lee-ching, or wall of ten thousand lee, taken near the pass of Con-pe- 
koo. At this place the wall is carried over the summits of the highest mountains, some of which are not less than three thousand feet in perpendicular height, and appear to be almost inaccessible. Some of the towers are in ruins, as that in the fore-ground of the view; but others, which more immediately command the passes, are kept in good repair. This wall, according to the cliarts of the empire made from actual surveys, is more than fifteen hundred miles in length, and in many places it is double, and cren triple, for the better defence of the passes. The masonry and brickwork in the towers alone exceed those of all London.

XXV. The approach of the Emperor of China to his tent in Tartary, to receive the British Embassador.

This tent was erected for the purpose, in a part of the grounds belonging to the palace, and called Van-shoo-yuen, or garden of ten thousand trees. Before the tent were arranged in two ranks, a great number of persons, consisting of tributary princes, representatives of sovereigns, ministers of state, governors of provinces, officers of the tribumals, and other mandarines of rank, waiting the approach of the Emperor, who is borne in an open chair supported by sixteen men. The British Embassador and his suite stood at the front of the rank, on the right hand side, in advancing towards the tent.

XXYI. Plan, section, and clevation of Poo-ta-la, or great temple in which the lamas worship, near Zhe-hol, in Tartary. The roof of the middle part of this immense building is said to be covered with tiles of solid solil.

Sxvil. A view of Poo-ta-la, or great temple, near Zhe-hol, in Tarsoly: with the town of Zhe-hol in the distance, aken from a hill in the Empuror's park. The sualler buildings which surround this large fubric we the hubitations of the priests, or lamas, about eight hundred of which are attirlecel to this temple. 
XXVIII. Punishment of the Tcha. This, usually called by Europeans the Cangue, is a common punishment in China for petty offences. It consists of an enormous tablet of wood, with a hole in the middle to receive the neck, and two smaller ones for the hands, of the offender, who is sometimes sentenced to wear it for weeks or months together. He is suffered, provided his strength will enable him, to walk about; but the burden is so great, that he is generally glad to seek for a support of it against a wall or a tree. If a servant, or runner of the civil magistrate, trkes it into his head that he has rested too long, he beats hin with a whip made of leathem thongs till he rises. Near the gate of the Embassador's hotel, in Pekin, half a dozen of these instruments were placed in readiness, to clap upon the shoulders of any of the Chinese servants who should happen to transgress.

XXIX. A view in the gardens of the imperial palace of Pekin. This is an artificial mount thrown up round the palace of Pekin, and is that on which the last of the Chinese Emperors, before the accession of a Tartar family, on hearing that the usurpers had entered his capital, first hanged his daughter, and then stabbed himself. The mountains at a distince are those behind the palace of Yuen-men-yuen.

XXX. A dramatic scene on the Chinese stage. The principal story of the piece, of which this scene represents a part, is taken from the ancient history of the country. It opens with the account of an emperor of China and his empress, who, in the midst of perfect felicity and apparent security, are surprised by a sudden revolt among their subjects. A war ensues; many battles are fought upon the stage; and at length the archrebel, a general of cavalry, characterized on the stage by a whip in his hand, overcomes his sovereign, whom he slays with his own land. The captive empress appcars in all the agonies of despair naturally resulting from the loss of her husband, as well as of her state and dignity, and indeed danger of her honour Whilst she is uttering lamentations, and rending 
the shies with her complaints, the conqueror enters. Of this scene the plate is a represcntation. He approaches her with respect, addresses her in a gentle tone, attempts to soothe her sorrows, talks of love and adoration; and, like Richard the Third and Lady Anne in Slakspeare, in less than half an hour prevails on her to dry up her tears, to forget a dead hushand, and to console herself with a living one. The persuasions of her own officers and attendants in fuvour of the general, have more weight with the lady than the supplicating priest, who, prostrate on the ground, intreats her not to marry the murcierer of her lusband. The piece concludes as usual with the nuptials, and a grand procession.

The dresses wom by the ancient Chinese are still preserved in the drama. The band of music hus its situation on the back part of the stage; there is no change of scene; and, in general, the front of the theatre is exposed to the open air.

XXXI. View of a Pai-too, or, as it has usually been called, a triumphal arch. These sort of ornamented buildings are common in every part of China; some of stone, and others of wood. Most of them have been erected at the public expence, for perpetuating the memory of such persons as have rendered public services to their country, but many have been raised lior the mere gratification of persomal vanity. On some erections of a similar kind, the characters denote them to be of no further use than to point out, like ont guide-posts, the distances of places from the spot on which they stand. The building on the right hand corner of the plate is a cower or fortress, and that on the lelt, a place for theatrical representations, whichare always entirely open in front. In the centre, near the foot of the trimmphat anch, the punishment of the bastinado, or bamboo, is inflictiog on a person lor mishehaviour, by order of a civil magisuate.

XXXII. A Onan, or Mandanine, learing a letter from the Emperor of Chind. 'These may be comidered as exact portaits of beth nuan and horse. 
The letter bound across his shoulders in a wooden case, covered with silk, was one from the Enmper or of Chima to the King of Great Britain, and was caried hefore the Embassador ate ng the pavel roat liom P'ekin to Tong-tchoo. All passengers on the road, on meeting the ollicer cladrged with this imperial letter, were obliged to shew a proper respect to it, by stepping off the paved road, and if on horselsack, by dismomnting, while it passed.

XXXIII. A view near the city of Lin-tsin, on the banks of the grand canal. The principal building in this view is a $\mathrm{Ta}$, or Pagoda, as it has usually but improperly been called. These buildings generally consist of five, seven, or nine stories, and as many projecting roofs; and their height is from four to seven of their diameters. They are never intended for places of religious worship, as the Indian term given to them seems to imply, and as has been generally imagined; but have either been crected as momuments to the nuemory of some great person or event, or is merely as oljects for the termination of a view; and for this latter pupose they very frequently crown the summit of the highest hills. The buildings on each side of the plate, with pillars erected in front, are houses inhabited by public officers of the district; and the figures are gromps of peasantly assembling on the banks of the canal, to see the barges of the Embassy pass.

XXXIV. Plan and section of a sluice, or floodgate, on the grand canal of China, and of an inclined plane between two canals of different levels. The canals of China have no locks, like those of Europe; and their floodgates are totally different. These consist merely of a few planks let down separately one upon another, by grooves cut into the sides of the two stone abutments that project from each bank, leaving a space in the midklle just wide enough to admit a passage for the largest of their vessels. As few parts of a Chinese canal are level, but have a current one way or the other, the use of these sluices, assisted by other's cut through the sides of the hanks, is to 
regulate the quanticy of water in the canal. The glacis, or inclined plane, is had recourse to only where the surface of the country is too uneven to admit of a continued canal. The vessels are forced up these planes by means of capstans fixed on each pier; and if one machine on each side be found insulficient, holes are ready made on the top of the pier for receiving others. By the assistance of a number of men, who obtain a livelihood by constantly attending at those places, vessels are made to pass from one canal to another with great expedition.

XXXV. Chinese barges of the Embassy passing througl a sluice, or foodgate on the grand canal. When the planks that form these floodgates are first drawn up, and the surface of the water on one side happens to be considerably higher than that on the other, the vessels are carried through by the current with great rapidity. Tho the Chinese are rery dexterous in the management of their vessels thus shooting thro sluices, yet to prevent the possibility of accident, the soldiers that are stationed at small military posts, usually crected on the abutments, attend on each side with fenders of leather stuffed with wool, or some other sofi substance, to prevent the barge from striking against the stone pier. The double-roofed building on the left pier is a temple of religious worship, of which kind there are great numbers in almost every part of the country.

XXXVI. View across the lake Pao-yng, shewing its separation from the grand canal by a strong embankment of earth. In this lake an extensive fishery is carried on, principally by means of the Pelicanus Sinensis, or fishing corvorant of China. These birds are here trained up to the exercise of fishing, and sent from hence to all parts of the empire. At this place the barges of the Embassy halted, while their large single nasts were taken down and others erected in their stead, consisting each of two poles meeting together at the top, and extending at the bottom to each side of the vessel, where they tum on swivels, and may thus be lowered down speedily, so as 
to permit the barges to pass thro the arclies of bridges, which are very fre. quent in the southern part of the grand canal.

XXXVII. The Pelicanus Sinensis, or fishing corvontut of China. This bird appears to be a different species from any hitherto described by naturalists. Its specific character may be thus distinguished. Brown pelican, or corvorant, with white throat; the body whitish beneath, and spotted with brown; the tail rounded: the irides blue; the bill yellow.

XXXVIII. View of the suburbs of a Chinese city. The double-roofed building on the right hand side of the print is a temple of religious worship. The small box supported on four poles, and ascended by a ladder, a look-out house, one of which is erected at almost every military post; and the building with the gateway thro it serves as a repository for arms, clothes, and other military stores. The method of fishing with a net stretched out by four pieces of bamboo, and suspended to a long pole, as in the hands of the figure sitting on the bank of the river in the fore-ground, is an universal practice throughout the empire.

XXXIX. A view of the Chin-san, or golden island, in the Yrang-tsékiang, or great river of China. This island, situated in the middle of the Kiang where the width is near three miles, is the property of the Emperor. It is interspersed with pleasure-houses and gardens, and contains a large monastery of priests, by which the island is almost entirely inlabited. $A$ vast variety of vessels in form and size are constantly moving about on this large river. That on the left side of the print is an accurate portrait of a Chinese ship of war.

XL. Chinese barges of the Embassy preparing to pass under a bridge. Tho some of the bridges in China are sufficiently high to admit of vessels to pass through their arches without striking their masts, yct as there are vol. 1. 
others of a lower construction, the masts of all their barges are contrived to lower down occasionally. To prevent carriages from passing over those bridges that are intended only for the accommodation of foot passengers, they are ascended by steps, as appears upon that on the left side of the print, under which a communication is formed between the grand canal and another branching off from it, without any inconvenience to foot passengers, or those people whose employment is to track the barges.

XLI. View of the Lake Ser-hos, and tower of the thundering winds, aken from the Vale of Tombs. This lake, on the borders of which stands the wealthy and extensive city of Hang-choo-foo, with the surrounding scenery, is accounted one of the grandest, as well as most beautiful. spots in all China. The Lui-fung-la, or tower of the thmodering winds, standing on the point of a promontory jetting into the lake, forms a bold object. It is said to have been built in the time of the philosopher Confucius, who lived three centuries before the Christian aera. In the Vale of Tombs the variety of monuments is almost infinite. Abundance of naked coftins lie scattered upon the ground; and the sides of the hills that rise from the vale are thickly set with groups of sarcophagi, in the shape of small houses, uranged in such a mamer as to look like so many Lilliputian villages.

XLII. Economy of time and labour, cxemplified in a Chinese waterman. In the river Chen-tang-chiang, near Hang-choo-loo, very lusge boats are frequently managed by one man, who with great dextericy will mus thro a whole fleet of vessels, stecring his own boat with one hand, managing the sail with the other, and pulling a large oar with his loot; and at the same time smoking lis pipe with the greatest ease and indifference.

XLIII. The rok of Oung-yin, with an excavation near its base, serving as a temple and dwelling for several priests of Fo. This rock is composed of one solid mass of grey marbte, rising out of the margin of the 
river to a height exceeding six hundred feet. In a large rent near the base is a temple of two stories, ascented by flights of steps hewn out of the sides of the cavern. The faces of the rock on the side next the river are so step, that this dreary mansion can only be approached by water.

XLIV. The Scoop-wheel of China, for lifting water upon the banks of rivers for agricultural purposes. These wheels, which are very common in the southern provinces, are nude entirely of bamboo, are put together without a nail, and are from fifteen to forty feet in diameter. They come nearest to the Persian or bucket-wheel, but are materially different in the principle and construction. A wheel thirty feet in diameter will lift, in the course of twenty-four hours, near seventy thousand gallons of water. 


\title{
A LIST OF THE ENGRAVINGS
}

\author{
CONTAINED IN THE TWO QUARTO VOLUMES.
}

\section{IN THE FIRST VOLUME.}

1. Frontispiece. Chien-Lung, Ta-whang-tee, or Chien-Lung, the great Emperor of China, habited in the dress in which he usually appears when giving audience.

II. The Adansonis, or Baobab, sometimes called in English, the monkey bread-fruit tree of St.Jago, whose trunk at the base measures fifty-six feet in girth.

111. View of the largest of the islands of Tristan d'Acunha, whon bearing north, and distant three or four miles.

IV. A Cochin-chinese boat of ten pair of oars, belonging to the governor of the district of Turon.

V. Curions insects found on a particular plant growing on the borders of Turon bay, and suppose. to be those from which the white wax of the East is oltaincd.

VI. The fect and ankles of a Chincse lady, dressed with the bandages and shocs, such as are in gecneral worn; and also the leet undressed, to shew the manner of bending all the toes, except the great one, under the sole of thefoot. 
VII. The Chinese mariner's compass, with the divisions, Instactire, and circles, generally marked upon such as are to be applicd to muntical purposes; this engraving is the size of the instrument from which it was taken.

\section{IN THE SECOND VOLUME.}

VIII. Frontispicce. Portrait of his Excellency the Earl of Macartney, Embassador extraordinary from the King of Great Britain to the Emperor of China.

IX. The Hai-vang, or Neptune of the Chinese, as he appears in Haiching-miau, or temple of the sea god at Ta-coo. In one hand he holds a magnet, as emblematic of security; and a dolphin in the other, to shew his sovereignty over the inhabitants of the sea; his head, beard, and hair, are evidently intended as a personification of water.

$X$. Two men throwing water out of a river into a reservoir on the bank, by swinging a basket with a pair of ropes fixed to its opposite sides. The bucket that is suspended at the end of a pole, which turns upon another fixed upon the bank, is drawn by hand to be filled with water; it is then more than counterpoised by the weight which is fixed to the other extremity of the pole, and consequently drawn up without further trouble. Such machines are frequent along the banks of the Pei-ho, and other rivers of China, for raising water for the grounds.

XI. A female divinity in the temple of Tong-choo-foo, taken from a figure of wood. From the eye depicted on a brass plate, which is held in her hands, it is probably intended as a personification of Prudence. In a bronze vessel standing near her are burning some matches made from the dust of sandal wood, and mixed with other perfumes. 
XI1. A bronze vessel, five or six feet in height, standing on a hexagonal pedestal of stone in the middle of one of the courts of the temple at Tongchoo-foo. In tripods such as these, perfumed matches, pieces of tin foil, gilt and painted paper, or any other kind of burnt offerings, are placed by those who visit the temple, for the purpose of consulting their destiny.

XIII. The method by which large and heary packagges are transported from one place to another on men's shoulders. The plan will explain the manner of fixing the poles so that thirty-two men may apply themselves (two at each extremity of the poles, that are parallel to the sides of the package) with an cqual division of the burden.

XIV. The method of carrying sedan chairs belonging to persons of rank.

$\mathrm{XV}$. The manner of crushing rice and other grain or pulse, by raising a lever with the foot, at the opposite extremity of which is fixed a coneshaped stone, that falls into a semicircular bason of the same material.

XVI. A statue of bronze, intended as a representation of a lion, one of which is placed at each side of the great gateway of the first court leading to the hall of audience, at the palace of Yuen-men-yuen.

XVII. The Throne of the Emperor of Ghina in the hall of audience at Yuen-men-yuen. This throne is of carved wood, somewhat darker than, but much resembling, mahogany. The platform is covered with English scarlet broadcloth, and the imperial chair with yellow silk. The characters on the parallelogram above it, are epithets in praise of the Emperor, and that in the lozenge is that of foo, which signifies felicity, a character in high estimation among the Chinese. This character, written by the hand of the Emperor, is sometimes purchased by the curious Chinese at a very ligh price. 
XVIII. A carved Sceptre of jade stone, cmblematical in China of pas and felicity. One of the same figure, but of agate, was sent to his Magesty, one was presented to the Embissador, and another to the Minister Plenipotentiary; the purse annexed to the sceptre was given by the Emperor to the Embassador's page.

XIX. An Agate of extraosdinary size, supported on a mable pectestal in one of the Emperor's palaces in the gardens at Zhe-hol. This angate is four feet in length, is carved into a landscape, and bears a copy of verses written by the present Emperor.

XX. A mass of indurated earth and gravel, cemented together so as to have the appearance of solid rock; it is pyramidal, and stands on its smalles base on one of the hills near the town of Zhe-hol. Its height is about tivo hindied feet.

XXI. The Lui-shin, or spirit that presides over thunder, the Jupiter of the Chinese. This figure has the wings, beak, and talons of an eagle. In his right hand be bolds a mallet, to strike the kettle-drums with which he is surrounded, whose noise is intended to convey the idea of thumder, whilst his left is filled with a volume of undulating lines, very much resembling those in the hands of some of the Grecian Jupiters, and evidently meant to convey the same idea, namely, that of the thunderbolt, or lightning.

XXII. Two fishermen bearing their boat on their shoulders towards a lake in which they mean to fish, with the species of corvorant, that the Chinese have rendered docile and expert in that kind of employment.

XXIII. The manner of drawing up a large net upon the deck of a frshing boat. Many fishermen with thes families have no other habitation but boats such as these. 
xxxiv

A LIST OF THE ENGRAVINGS, de.

XXIV. An exact portrait of a Chinese bridge, and a barge with its masts struck, or lowered down, to enable it to pass under the arch.

XXV. One of the methods used in China for working the chain-pump, to raise water for agricultural purposes, out of one reservoir to another.

XXV1. Chinese plough, such as are most generally in use throughout the conntry. It has but one handle, and no coulter, this last being deemed unnecessary, as there is no lay-ground, and consequently no turf to cut thro in China.

XXVII. The Camelia Sesanqua, called by the Chinese Tcha-wha, or flower of tea, a plant which grows in great abundance, and without much cultivation, on the hills of the southern provinces. From the nut, or berry, of this plant, very much resembling, but larger than, the tea-seed, the Chinese express a very fine esculent oil, which is in high estimation with them.

XXVIII. The Cave of Camoëns at Macao, in which this poet is said to have composed his famous poem of the Lusiad: the column that appears to support the immense overhanging rock is modern, and perfectly unnecessary, the stone having for ages continued to lang without the aid of the pillar. 


\section{EMBASSY TO CHINA.}

\section{CHAPTER I.}

OCCASION OF THE EMBASSY.

$\mathbf{I}_{\mathrm{T}}$ has justly been observed, that the interests and pursuits of so active and opulent a portion of the comthe Embassy. munity as is engaged in trade throughout the British dominions, occupy, at all times, much of the attention, and, in the proper spirit of a commercial nation, influence many of the measures of the government. It was naturally supposed, therefore, when the determination was known of sending an embassy to Ghina from Great Britain, that it was undertaken for commercial purposes. In fact, the intercourse between the two countries was carried on in a manner that required a change. No circumstance had occurred, either when it was first attempted by the English, or since it has been established, that could tend to place it on a more advantageous footing for them. The natives of other European countries, who undertook to trade in China, were generally; in this respect, more fortunate.

The Portugueze were the first who frequented the Chinese coasts upwards of two centuries ago, and about 
Occasion of the period of their most brilliant exploits, as well as of the Embassy. the fame which necessarily followed them. They had rendered such signal services to the empire of China, that, in return, lands for building a town, near to a safe harbour at the southern extremity of the country, with several collateral advantages, were granted to them ; and notwithstanding the decline of their power and reputation has gradually led to an encroachment upon their privileges, the recollection of a long and useful connection contributes to procure them still, on the part of the Chinese, a more familiar and confidential reception, and, indeed, a marked preference, in particular instances, before other Europeans.

The Dutch, in consequence of assistance supplied by them for the reduction of a formidable rebel, named Coshing-ga, whose fleets infested the eastern coasts of China towards the middle of the last.century, were, for a time caressed by the established government; and invited even to Pekin, where the first emperor of the Man-choo Tartar race was then sitting on the throne. His successor, the great Cam-hi, or, as more accurately pronounced, Caung-shee, during a long and prosperous reign, received, very favoumbly, any forcigners skilled in such arts and sciences as were better understood in Europe than by his own subjects. He admitted many of those foreigners into his service and confidence; and employed some of them in political negotiations. They 
all happened to belong to different religious societics of the Roman Catholic persuasion, founded in different

parts of the continent of Europe; and were men, who being inspired with zeal for the propagation of the principles of their faith among distant nations, had been sent abroad for that purpose by their respective superiors. Several of those who arrived in China, acquired considerable esteem and influence, as well by their talents and knowledge, as by uncommon strictness of morals, disinterestedness, and humility: qualities and a conduct that leave little room for clashing, at least in temporal affairs, with the views of other men; and command the veneration even of those who are not disposed to imitate the example. By means like these, they not only gained proselytes to their religion, but gave a favourable impression of the countries from whence they came: thus, and by personal solicitations, serving the cause of such of their countrymen as were engaged in pursuits of commerce in any Chinese port.

But the English had no opportunity of rendering themselves acceptable by public services; nor had they any other means of securing respect for their character, or protection for their trade. Mercantile speculations, to other distant countries; from England, had indeed been encouraged, and assisted by the special countenance and recommendation of the sovereign upon the throne.

"Queen Elizabeth" according to the history of com- 


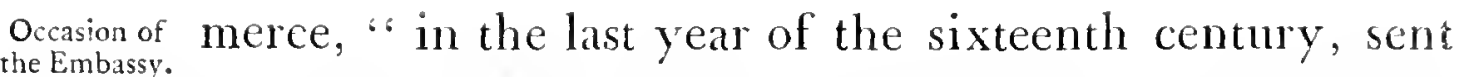
the Embassy. "out John Mildenhall over land from Constantinople "to the court of the Great Mogul for obtaining certain "privileges for the English, for whom she was then " preparing a charter. He was long opposed by the arts " and presents of the Spanish and Portugueze Jesuits at " that court; and it was some years before.he could " entirely get the better of them." It is recorded, that the same wise princess wrote strong recommendatory letters to the emperor of China, to be delivered by the chiefs of an expedition intended for that country in her time; but misfortunes at sea prevented the ships from ever arriving there. Nor does it appear that any regular trade was afterwards attempted with that empire, to which the Portugueze seem to have long arrogated the exclusive privilege of resorting, until the year 1634 , when a truce and free uade to China, and all other places where the Portugueze were settled in India, was agreed to between the viceroy of Goa and several English merchants, to whom a license for trading to the East Indies had been granted by King Charles the First, notwithstanding the exclusive charter of Queen Elizabeth to others.

Several ships were fitted out by these grantees, under the command of Captain Weddell, who thought it sufficient, in conseruence of the agreement made at Goa, to bring letters for the governor of Macao, in order to be ellectually assisted in his projected intercourse with the 
Chinese at Ganton. But according to the manuscript account of that voyage, which seems to have been drawn the Embassy. up without disguise, "the procurador of Maccow soon " repaired aboard the principal ship of the English, " and said, that for matter of refreshing, he would pro"vicle them; but that there was a main obstacle to their " trading, which was the non-consent of the Chineses, "who, he pretended, held his (the Portugueze) people " in miserable subjection. The English determined, " however, to discover the river of Canton; and fitted " out a barge and pinnace with above fifty men, which, " after two days, came in sight of the mouth of the " river, being a very goodly inlet, and utterly prohi" bited to the Portugals (Portugueze) by the Chineses, " who do not willingly admit any strangers to the view " of it, being the passage and secure harbour for their " best jounckes, both of war and merchandize; so that the "Portugal traffic to Canton was only in small vessels, " through divers narrow shoaled straits, amongst many " broken islands adjoining to the main. The barge an" choring for a wind and tide to carry them in, a jouncke " of those that accustom to fish was descried early in the " morning, whom Thomas Robinson followed, (a te" dious chase by reason of their many oars) hoping to " have found some aboard that might have stood either " of a pilot or interpreter ; but finding neither, having " used them with all courtesy, dismissed them, contrary 
Occasion of "to their timorous expectation; and afterwards, for the the Embassy,

" same causes, and with the same success, spake with " another; but after a delay of several days a small boat " made towards the pinnace; and having sold some re" freshing, signs were made to carry some of the English " to Canton, and bring them to the speech of the man" darines; which the boatmen accepted of: but the next " day, the pinnace being under sail with a fair wind " and tide, after having passed by a certain desolate " castle, a fleet of about twenty sail of tall jounckes, com" manded by the admiral of the sea's deputies, passing "down from Canton, encountered the English; and, " in courteous terms, desired them to anchor, which ac" cordingly they did; and presently John Mounteney, "and Thomas Robinson, went aboard the chief man" darine, where were certain Negroes, fugitives of the "Portugalls, that interpreted.

"At first the Chinese began somewhat roughly to ex" postulate what moved them to come thither, and dis" cover the prohibited goods, and concealed parts and " passages of so great a prince's dominions? also, who "were their pilots? Thomas Robinson replied that they " were come from Europe, to treat of such capitulation, " as might conduce to the good of both princes and sub" jects, hoping that it might be lawful for them, as well "as for the inhabitants of Maccow, to exercise a free "commerce, paying duties as the others; and as for 
" pilots, they had none; but every one was able, by his

" art, to discover more difficult passages than they had

" found. The Ghinese hereafter began to be more affable,

" and, in conclusion, appointed a small jouncke to carry " up Captain Garter, Joln Mounteney, and Thomas Ro"binson, or whom else they pleased to the town (of "Canton), if the English would promise that the pin"nace should proceed no further; for though each of " these vessels was well furnished with ordnance and " treble manned, yet durst they not all to oppose her in " any hostile way. The same night Captain Carter, "Thomas Robinson, and John Mounteney, left the " "pinnace, with order to expect their return; and, being " embarked in a small jouncke of thirty tons, proceeded " towards Canton, with intent to deliver a petition to " the viceroy, for obtaining of license to settle a trade in "those parts. The next day they arrived within five "leagues of Canton, whither it seems the rumour of their " coming, and fear of them, was already arrived; so that " they were required in a friendly manner to proceed " no further, but to repair aboard their own ships, with " promise of assistance in the procuring of license for " trade, if they would seek it at Maccow by the solici" tation of some they should find there; and would in": stantly abandon the river: the which (having satisfied " themselves with this discovery, and willing to remove " the anxiety which their long absence might breed 
Occasion of " in the rest of the fleet) they readily performed. In a
theEmbassy. the Embassy. " little time the Portugalls' fleet of six small vessels set "sail for Japan; upon whose departure it was expected " that license of trade would have been permitted, ac" cording as they still had borne in hand the English; " but being then freed of their conceived fear lest Cap" tain Weddell and his men should have surprised their " vessels, they instantly flouted the simple credulity (the " inseparable badge of folly) of the nation; and, at last, " having assembled a council of purpose, sent the Eng" lish a flat denial. The same day at a consultation "called aboard the admiral (Weddell) to that purpose, " Captain Carter, John Mounteney, and Thomas Robin" son, delivered to the whole council, together with a " draught of the river, the sum of their attempts, success, " and hopes; which being well pondered, it was gene" rally consented, that the whole fleet should sail for the " river of Canton. They arrived, in a few days, before " the forementioned desolate castle; and being now fur" nished with some slender interpreters, they soon had " speech with divers mandarines in the king's jounckes, " to whom the cause of their arrival was declared, viz. " to entertain peace and amity with them, to traffic freely " as the Portugalls did, and to be forthwith supplied for " theirmonies, with provisions for their ships: all which " those mandarines promised to solicit with the prime " men resident at Canton; and in the mean timedesire an 
"expectation of six days, which were granted; and the "English ships rode with white ensigns on the poop; " but their perfidious friends, the Portugalls, had in all "that time, since the return of the pinnace, so beslan" dered them to the Ghinese, reporting them to be rogues, "thieves, beggars, and what not, that they became very " jealous of the good meaning of the English; insomuch "that, in the night time, they put forty-six of iron cast " ordnance into the fort lying close to the brink of the "river; each piece between six and seven hundred "weight, and well proportioned; and after the end of "four days, having, as they thought, sufficiently forti" fied themselves, they discharged divers shot, though " without hurt, upon one of the barges, passing by them, " to find out a convenient watering place. Herewith the " whole fleet, being instantly incensed, did, on the sud" den, display their bloody ensigns; and, weighing their " anchors, fell up with the flood, and birthed themselves " before the castle, from whence came many shot; yet " not any that touched so much as hull or rope; where"upon, not being able to endure their bravadoes any " longer, each ship began to play furiously upon them "with their broadsides; and, after two or three hours, "perceiving their cowardly fainting, the boats were "landed with about one hundred men; which sight " occasioned them, with great distractions, instantly to a" bandon the castle and fly ; the boats' crews, in the mean VOL. I. C 
Occasion of " time, without let, entering the same, and displaying
theEmbassy. "his Majesty's colours of Great Britain upon the walls, " having, the same night, put aboard all their ordnance, "fired the council-house, and demolished what they "could. The boats of the fleet, also, seized a jouncke " laden with boards and timber, and another with salt. "Another vessel, of small moment, was surprised, by " whose boat a letter was sent to the clief mandarines at "Canton, expostulating their breach of truce, excusing "the assailing of the castle, and withal, in fair terms, "requiring the liberty of trade. This letter, it seems, "was delivered; for, the next day, a mandarine of no "great note, some time a Portugal Christian, called Paulo "Noretty, came towards the ships in a small boat with " a white flag, to whom the English, having laid open " the injuries received, and the sincere intent they had " to establish fair trade and commerce, and were no way " willing (but in their own defence) to oppose the China " nation, presented certain gifts, and dismissed him to " his masters, who vere some of the chief mandarines, " ridingabout a point of land not far from the ships, who, " being, by him, duly informed thereof, returned him "again, the same night, with a small jouncke, and full "authority to carry up such, as should be appointed, to "Canton, there to tender a petition, and to conclude "further upon the manner of their future proccedings. "John Mounteney and Thomas Robinson passed up the 
"river, and, the next evening, arrived at the city, an-

"choring close under the walls, in sight of the palace of

"Champin, the admiral-general, and, on the morrow,

" having procured a petition to be formally drawn up, by

" the means of the said Noretty, they were called ashore.

" and, passing through a treble guard, and, at length,

"coming in sight of the chiefs assembled, they were

"willed, according to the custom of the country, to

" kneel; and Thomas Robinson, holding the petition at

" large extended upon his head, delivered it to Noretty

" to carry up to Champin; the contents whereof be so

" reasonable, as before specified, he presently consented

"unto, and promised his utmost assistance; blaming

" the treachery of the Portugalls, whom he taxed as au-

" thors, by their slanders, of all the precedent incon-

"veniences: they returned from Canton fully satisfied,

" and hereupon the Chinese guns were landed and de-

"livered into their hands; their jounckes freely dis-

" missed, and a seeming peace on all sides ensued."

The whole of this relation marks the moderation of the Chinese towards strangers, or, perhaps, the weak and unsteady administration of a declining dynasty; but shews, at the same time, under what adverse auspices, the English were first introduced in China: these rash adventurers appearing as if not belonging to any nation, or avowed by any power, and misrepresented by those on whom they had placed dependance: nor had they 
Occasion of been preceded by any English traveller, actuated by mo-
the Embassy. tives of piety or curiosity, who might announce, at least, the name of his country to some advantage. It continued to be so little known, even after the English had begun to traffic at Canton, that they were long distinguished, only, by the contemptuous appellation of Hoongmoze-zhin, which, as nearly as can be translated, may answer to that of carotly-pated race.

When the vast increase of the shipping of the English at Canton, and the eclat of their victories in Hindostan, as well as their conquest of the Philippine Islands in the Chinese seas, had attracted the attention of the court of Pekin, the answers, to inquiries concerning them, from the missionaries, being the only Europeans to be consulted there, probably partook of the national and religious prejudices imbibed, until of late, by persons of that description, against the English. It must have required a long course of very reserved and cautious conduct on their part, to efface any unfavourable impressions given of them by other natives of Europe. But with such a conduct it was sometimes difficult to reconcile the independent spirit and freedom of action, resulting from the nature of the British government; and which might, hovever justifiable, have sometimes worn the appearance of presumption in the eyes of the supercilious and abbitary magistrates of China, especially when observable in persons of a mercantile pro- 
fession, which happens to be the lowest class in estimation there. Its more frequent, and worse consequences proceeded from the abuse of liberty in the valgar and uninstructed minds of British seamen, and other persons in inferior stations. Their passions and caprices, being in great measure unrestrained, they exhibited such scenes of excesses and irregularities as were peculiarly disgusting and offensive to a people, whose minutest actions are controlled by specific regulations.

From these causes, of all foreigners frequenting the port of Canton, the English were certainly depicted in the most unfavourable colours to the government of the country; and probably treated with the greatest rigour upon the spot. And thus the imperial officers, under whose immediate inspection they were placed, were in little danger of reprehension for any ill treatment of their persons, or impositions upon their trade. Their complaints were considered as frivolous or ill-founded; and attributed to a restless and unreasonable disposition. Effectual measures were, likewise, taken to avoid a repetition of their remonstrances, by punishing such of the natives as were suspected of having assisted in translating the papers which contained them, into the language of the country. The few English, who were in any degree acquainted with that language, being necessarily brought forward for the purpose of communicating their grievances, became particularl y obnoxious: 
and this circumstance contributed to deter others from any attempt to acquire it; and, indeed, to teach it to them was found to be a service of some danger. They were, thus, under the necessity of trusting entirely to the native merchants themselves, with whom they had to deal ; and who found their account in acquiring, at least, as many English words as were necessary for carrying on their mercantile concerns. Besides, the vast superiority of rank, over all merchants, assumed by persons in authority in China, became an obstacle to all social or familiar intercourse between them, and the only Englishmen who went there. And, notwithstanding a British factory had been established upwards of an hundred years, not the least approach was made towards that assimilation of manners, dress, sentiments, or habits, which, in similar institutions elsewhere, tends so much to facilitate the views of commerce, as well as to promote the comforts of those immediately engaged in it.

Under such circumstances, the ancient prejudices against all strangers, always great in proportion as there is little communication with them, could scarcely fail to continue in their full force: those prejudices, not only operating upon the conduct of the Chinese, but reduced into a system, supported on the fullest confidence in the perfect state of their own civilization; and the comparative barbarism of every other nation, suggested the 
precaution of making regulations to restrain the conduct of all Europeans frequenting their coasts; as if aware of the necessity of preventing the contamination of bad example among their own people. One port only was left open for foreign ships; and, when the season came for their departure, every European was compelled to embark with them, or leave, at least, the Chinese territories: thus abandoning his factory and unfmished concerns, until the return of the ships in the following year. There was little scruple in laying those restrictions on foreign trade, the government of Ghina not being impressed with any idea of its importance to a country including so many climates, and supplying within itself, all the necessaries, if not all the luxuries, of life.

Tho the natives, immediately engaged with foreigners in mercantile transactions, have been very considerable gainers by such an intercourse, the body of the people is taught to attribute the admission of it, entirely, to motives of humanity and benevolence towards other nations standing in need of the produce of China, agreeably to precepts inculcated by the great moralists of the empire; and not to any occasion or desire of deriving reciprocal advantage from it.

For a considerable period, indeed, there was litte demand for European goods at the Chinese markets; and the consequent necessity of paying for the surplus 
Occasion of value of their commodities in money, an object so
the Embassy. the Embassy. to remit cash elsewhere, was thought, in Ghina, where such a want seldom could occur, to be productive of little other alteration than to increase the relative weight of the metal representing property; and which increase was in that respect considered rather an inconvenience than a benefit.

With such an opinion of foreign trade, those, who presided over it, being indifferent to its progress, and suffering it, rather than seeking for it, there was a very slender chance of favourable attention, or even common justice, towards the strangers who carried it on ; especially the English at Ganton, who had not the faculty of asserting their own cause upon the spot; and were entirely without support at the capital, where their hardships might be redressed. They were, in fact, subjected to many oppressions in their dealings, and insults upon their persons. They did not, however, conceive that such treatment was authorized by the Emperor of China, or even known to him; and therefore several of the East India Company's agents, employed in the Chinese trade, suggested the propriety of an cmbassy to his Imperial Majesty, to represent their situation, in the hope that he might issue orders for the removal of the grievances under which they laboured. Intelligent men, who had resided at Pekin, 
and being, as mathematicians or artists, in the service of the court, had occasionally an opportunity of observing the Embassy. the disposition of those who composed it, were of opinion that such a measure, properly supported, could not fail of having a good effect. The English, hitherto, were scarcely known there, except through the prejudiced medium of their adversaries or rivals. Those who resided at Canton were merely considered as individuals, who, not having been recommended, or expressly avowed by their own sovereign, might not be thought entitled to any particular protection. It was urged, that a British Ambassador would be a new spectacle; and his mission a compliment, that would probably be well received. Upon general reasoning, it appeared, that every motive of policy or commerce, which led to the maintenance of ministers from Great Britain, at European courts, and even in Turkey, applied, with equal strength, to a similar establishment, if practicable, at Pekin. The trade between the subjects of the two countries amounted, annually, to some millions sterling; and, tho the kingdom of Great Britain be distant several thousand miles from the capital of the Chinese empire, the dependent territories of each state approached each other within about two hundred miles, on the side of Hindostan. Much of the intermediate space between the eastern boundary of the British government of Bengal, and the western limits voL. 1 . 
Occasion of of the Chinese province of Shen-see, was occupied by
the Embassy. $\stackrel{\text { the Embassy. }}{=}$ petty princes, frequently at variance with each other; but intimately connected with, or dependent upon, one or other of their two powerful neighbours. Such a relative situation must, in the common progress of events, give rise, as has already been experienced, to discussions, which might, without the interposition of persons in a public and confidential character, lay the foundation of dangerous differences between the two courts.

A similar evil appears not less to be apprehended, in the course of an extensive commercial intercourse, in another extremity of China. An accident, indeed, happened at Canton, not many years ago, which is said to have very much endangered the continuance of its foreign trade. On some occasion of compliment, or rejoicing, the guns were fired from one of those vessels which navigate between the British settlements in India and Canton, but not in the employment, or under the regulations or discipline, of the English East India Company: through want, no doubt, of sufficient precaution on the part of those who directed the fring, two Chinese were killed in a boat, lying near the vessel, in the river of Canton. The crime of murder is, certainly, less frequent, and excites sensations of deeper horror in China, where it is never pardoned, than it does in wany parts of Europe. The viceroy of the province, 
feeling the utmost indignation at the supposed atrocity, or wantonness, of an act, by which an Ruropean deprived two Chinese of life, instantly clemander the person of the gunner who committed the fact, or of him who ordered it; the latter, already, had absconded; and the former, merely acting in obedience to his superior, was consequently considered as guiltless by the English factory, and was endeavoured to be protected by it. Remonstrances were made, stating the unfortunate event to have been entirely accidental. Nevertheless the viceroy, prepossessed by an ill opinion of the English, as prone to every kind of wickedness, would not be satisfied without a victim to expiate the mischief that had happened, and insisted upon the man's being delivered up to him; and, to secure that object, seized upon the person of one of the principal supercargoes. This extraordinary step alarmed the other factories, and united them with the English, as in a common cause. The European ships, then lying in the Canton river, were in considerable number and force; their commanders and the individuals of the factories seemed to collect together, and to dispose themselves for resistance to the intentions of the viceroy; who immediately ordered vast numbers of his troops to line the banks of the river, and prepared to obtain his purpose by compulsion. He was, perhaps, the less cautious or backward in taking this strong measure. 
as its justification would depend upon his own statement of the facts to the Emperor, who might thus easily be brought to feel resentment, and approve of vengeance against the English; they having, at the Imperial court, no means of disputing the representation of the viceroy, or of averting the execution of his designs. Extremities were avoided only by the delivery of the unhappy gunner, with some vain hope that he should not be made to suffer.

If any conflict had taken place, the loss of those who might fall on both sides, upon the occasion, would not, perhaps, be the only ill consequence resulting from it. Very serious apprehensions were entertained, lest the Chinese government, which easily takes alarm, and foresees the possibility of the remotest evils, should be disposed to prevent effectually the return of such a scene; and avoid the chance of exposing the lives, or disturbing the tranquillity, of its subjects, by putting a total stop to foreign trade.

It is not merely the privation of the profit that would be sustained by the East India Company, or of the duties payable to the state, that would be felt by the cessation of the trade to China; nor even the stagnation, in this respect, in the sale of British manufactures in that country; where the East India Company, by sacrifices which individuals could not make, have succeeded in carrying it to an unexpected extent. Notwithstand- 
ing the violence of the shock, which such a stoppage would create, other openings might gradually be struck out for commerce; which will gemerally be found to make its way, and flourish, at length, under the auspices of a good government, nearly in proportion to the capital, industry, and ingenuity of the people inclined to carry it on.

But, independently of every consideration of gain, it happens, in fact, that one of the chief articles of import from China, and not to be had elsewhere, was become a necessary of life in most of the ranks of society in England. Until teas, of similar qualities with the Ghinese, could be procured from other countries, in equal quantities, and at as reasonable a price as they were then imported from China, no precaution was to be neglected, which could secure the usual supply of that article from thence, while the desire of its daily use continued undiminished in Great Britain.

Tea, it is true, was not known in any part of Europe before the commencement of the last century. Some Dutch adventurers seeking, about that time, for such objects as might fetch a price in China, and, hearing of the general usage, there, of a beverage from a plant of the country, bethought themselves of trying how far an European plant, of supposed great virtues, might also be relished by the Chinese, and thereby become a saleable commodity amongst them; and, accordingly, 
Occasion of introduced to them the herb sage, so much once exthe Embass. tolled by the Salernian school of physic, as a powerful preservative of health: the Dutch accepting, in return, the Chinese tea, which they brought to Europe. The European herb did not continue, long at least, in use in Ghina; but the consumption of tea has been gradually increasing in Europe ever since. In England, about the middle of the last age, the infusions of it were already sold in houses of public entertainment; and became an object of taxation to the legislature. The annual public sales of teas, by the East India Company, did not, however, in the beginning of the present century, much exceed fifty thousand pounds weight, independently of what little might be then, perhaps, clandestinely imported. The Company's annual sales, now, approach to twenty millions of pounds; being an increase of four hundred fold, in less than one hundred years, and answers to the rate of more than a pound weight each, in the course of the year, for the individuals of all ranks, sexes, and ages, throughout the British dominions, in Europe and America.

No substitute, that could be offered, would prevent the sudden deprivation of an article, in such universal consumption and request, from being considered as a calamity. Steps have, indeed, been taken for the purpose of introducing its cultivation in those parts ol the 
British territories in Hindostan, of which the soil and climate are supposed most congenial to its growth; and in the island of Corsica, a small plantation of it is the Embassy. said, actually, to be flourishing; but at an expence, in the preparation of it, exceeding the value of the produce. The probability is, lowever, strong, that the supply of this article, at a reasonable price, may, at a future time, be secured without depending upon the will of a foreign power. But prudence required to guard against its failure in the mean time, by endeavouring to form such a connection with the court of Pekin, as might, in its consequences, tend to place the British trade to China upon a less precarious, and more advantageous footing, than hitherto it had stood; as well, also, as to prevent the difficulties, and allay the jealousies, which the intrigues and misrepresentations of the respective dependents or allies of China and Great Britain, might be likely to occasion on the side of Hindostan.

It was not to be expected that such a connection could, on a sudden, be brought abont; or its objects be at once completed. The court of Pekin was understood to be guided by maxims peculiar to itself, little fond of a promiscuous intercourse with foreign states, and inclined, in some measure, to consider its subjects as placed in the vale of happiness, where it was wise to seclude them from a profane admixture with other men. The 
Occasion of exception to such a rule was not likely to be made, at the Embassy. once, in favour of a nation, of whose wealth, enterprize, and power, the Emperor and mandarines were sufficiently persuaded; but of whose virtues they had little heard.

A succession of British subjects, residing in a dignified station at Pekin, whose cautious conduct and courteous manners would be calculated to gain the esteem of the upper, and the respect of the lower classes of the Chinese, might, by dissipating their prejudices, and conciliating their good will, produce the confidence necessary to a desirable alliance with them. The admittance of such, however, in the first instance, might be a matter of some difficulty and liazard. A British subject in the service of the East India Company, who had attained the language of the country, by having been sent to Canton at a very early age, and had remained long in it, was punished, by express order from Pekin, for having attempted to penetrate to tlat capital, with a view of presenting, in obedience to his superiors, a memorial of grievances from the British factory.

It was presumed, that better success might attend an envoy of rank, invested with a royal commission, which commands respect in cvery civilized society; and a person of noble birth, and distinguished merit, undertook to make the experiment. He was accompa- 
nied by gentlemen of ability and knowledge; but the expedition was interrupted by his premature decease the Embassy. in the course of the voyage out. This event retarded, but did not prevent, the prosecution of the measure originally intended. Fresh circumstances occurred to press its execution. A more comprehensive view, also, was taken of the subject; and considerations of humanity and philosophy were superadded to those of policy and commerce. Among the transactions which give lustre to the present reign, some of the most memorable were the voyages undertaken under the immediate auspices of the Sovereign, whereby the boundaries of science were enlarged, and the globe was circumnavigated, without the incentives of gain or conquest. But advantages were obtained more durable, and more worthy of elevated minds. One man, chosen by government, as fitted for arduous undertakings, by intrepidity and judgment, as well as by the extent of his acquirements, was enabled to make considerable improvements in navigation and geography; and, after successive trials, to determine points of much previous doubt and curiosity, as well as of general importance; while another, stored with the knowledge of whatever former naturalists had observed, and making, for the sake of further researches, a voluntary sacrifice of the enjoyments of fortune, at an early age, to encounter the extremities of opposite climates, and the perils of unvol. I. 
Occasion of known routes, succeeded in enriching the history of $\stackrel{\text { the Enbass. }}{\longrightarrow}$ nature in its several departments. Enterprises sucl as these were so much above the usual course of things, and the motives of ordinary actions, that, in the midst of war, they were held sacred by an admiring enemy; and, without solicitation, were excepted from the danger of the hostile attacks, to which every other English property and person was exposed.

As individuals, growing into affluence, derive just praise from generous exertions in behalf of the community; so kings and nations, in prosperity, cannot, with greater glory, avail themselves of their situation, than by directing a part of their attention towards enlightening mankind; and promoting the general happiness of the human race. Nor is such a conduct barren of direct advantage to those who hold it: no state can flatter itself with abounding so much in the riches of nature, or of being already arrived to such perfection in the arts of applying them to the purposes of life, as not to be susceptible of any further augmentation or improvement. If countries, little advanced in civilization, are capable of sometimes supplying valuable information, it is probable that much more might be collected, from the recorded or traditional experience of the most ancient socicty, and the most populons empire existing amongst men.

The few, who had hitherto found means to penetrate 
into China, had contributed rather to raise the attention of other persons, than to satisfy their enquiries. Of the accounts given of it, some were contradictory, and some suspicious; but all concur in ascertaining that, in respect to its natural and artificial productions, the policy and uniformity of its government, the language, manners, and opinions of the people, their moral maxims, and civil institutions, and the general economy and tranquillity of the state, it is the grandest collective object that can be presented for human contemplation or research. The obstacles to a familiar investigation of it arose, no doubt, on the part of the Chinese government, from the fancied danger of communicating with strangers prone to disturbance or immorality. This opinion could be corrected only by such strangers affording examples of a contrary tendency.

But it might not be safe to trust to the effect of examples of ordinary rectitude, without the concomitant qualifications for moving in a scene so novel, and amidst prejudices so inveterate. An Embassador once admitted, the success of the general plan would, certainly, much depend on the impression he and his attendants would make, during his journey through the country; and his visit to the court. If he should have the method of rendering himself acceptable to the people; if he could gain the good opinion of the mandarines; thus operating, in fact, a favourable change 
Occasion of in the ideas that had been entertained of the nation
the Embassy. which had sent him ; and, lastly, conld excite a wish for the regular residence of succeeding ministers contrary to the former usages of the Chinese, the immediate object of this first attempt would be accomplished, and a firm foundation laid for the attainment of every good which might result from an intimate intercourse with all parts of China. This, however, could only be the work of time, and might be retarded by aiming at too much in the beginning. Some of the most judicious directors of the East India Company, tho perfectly aware of all the hardships under which its commerce laboured at Canton, but feeling how much more the Company would suffer by its absolute discontinuance, recommended the utmost precaution to be used in the early periods of negotiation; lest, by eagerly contending for the redress of grievances, or prematurely insisting upon further privileges, the government of Ghina should take alarm or offence; and think it time, effectually, to prevent the danger of encroachment, or dispute, by shutting its ports entirely against foreigners.

It behoved the British administration, therefore, to select a person of tried prudence, as well as of long experience in distant courts and comntries, to enter upon a business of such delicacy and difficulty; and who would be contented with securing future success, without enjoying the splendour of instant advantages. 

It was an office, of which it could not be suspected that Occasion of it would be conferred through personal favour, or parliamentary influence. The minister, indeed, had already in several instances of great and responsible enployments connected with the East India Company, shewn the example of recommending, from the sole consideration of the qualifications requisite to fill them; and appointments the most valuable and important were made where they were neither solicited nor expected. A proper person was thus, in like manner, to be sought for on the present occasion; but some time elapsed before the choice was ultimately fixed. 


\section{CHAPTER II.}

PREPARATIONS FOR THE EMIBASSY.

Preparations for the

However flattering patronage may be considered Embassy. to a minister, it becomes, on occasions of importance, a duty nice and difficult to perform. He is not more answerable for the measures he adopts, than for the choice of those to whom he confides their execution. As to the former, he may have credit given to him for the exercise of his judgment without any particular predilection; but, in suiting persons to employments, it behoves him, in order to escape censure, to be equally on his guard against his own partialities, and the solicitations of his most intimate connections; and he finds himself perfectly secure, only, when his private opinion coincides with the general voice.

Such was the case in the appointment of an Embassador to China. Lord Macartney was in the number of those whose reputation was established for talent, integrity, and an aptitude for business. Few men had been tried in a greater variety of situations; and he was, perhaps, the only man whose conduct (on his return from a high station in India) the opposite parties in the legislature, united in applauding; and his friends en- 
joyed the satisfaction of hearing his eulogy pronounced, Preparation, on the same day, from the mouths of the two great op- Embassy. posing leaders in the House of Commons. While he was formerly his Majesty's Envoy at Petersburg, he concluded, with that court, a commercial treaty to subsist for twenty years, on such advantageous conditions, that the sovereign of Russia, at length, perceiving the balance to be too much in favour of Great Britain, refused, for a considerable time, to renew it. His Lordship had other occasions, afterwards, to exert both address and prudence, for the public advantage, in different quarters of the globe. He had since, indeed, declined the government-general of Bengal, of which the power and the profit exceed, no doubt, that of any other within the recommendation, or the gift, of ministry. But a visit to the court of Pekin was, on other accounts, so uncommonly inviting; it presented so much to an ardent and inquisitive mind, that, upon the first intimation, he readily engaged in the attempt.

His Lordship made no stipulation with government, on accepting this employment; but Mr. Dundas, Secretary of State, who planned and undertook the whole of this measure, and to whom, whatever advantage may ultimately result from its adoption, must, certainly, be attributed, very readily offered to allow a friend of Lord Macartney (who, in negotiating the peace with Tippoo Sultaun in 1784, had some opportunity of acquiring 
Preparations experience) to accompany his Lordship as his Majesty's
for the Embassy. Secretary of the Embassy, and eventual successor to the Embassador. His Lordship's recommendations were accepted in every other department of the Embassy.

By what route the expedition should proceed to China, could not long admit of doubt. Tho Pekin lies on the same side of the equator as London, with a difference of only eleven degrees of latitude; and tho a direct line from one capital to the other, passes over very little sea, and through countries which nature has rendered pleasant, and where the atmosphere is mild and healthy; yet the state of human civilization, through this long tract of 5790 English miles, is, in many parts, too imperfect to admit of travelling with ease, safety, or dispatch. The passage by sea, therefore, was alone found practicable, notwithstanding it is so circuitous, as to be more than thrice the actual distance between China and Great Britain.

On this occasion the first Lord of the Admiralty, thinking one of his Majesty's ships could not be better employed in time of peace, determined that a sixty-four gun ship should carry the Embassador out and home; and was pleased, also, to leave it to Lord Macartney to nominate the commander. This nomination was far from being a matter of indifference; for, beside the proper qualifications to conduct any very long voyage, with salety and comfort to the passengers and crew, still 
more might, possibly, be requisite in an undertaking Preparations in which a new tract of sea was to be explored; as it Eimbassy. became a part of the plan to sail directly for the harbour next to the capital of China, through the Yellow sea and the gulf of Pekin, for a space of ten degrees of latitude, and more than half that quantity of longitude; of no part of which there was any recorded account, by European navigators. As this sea is, except at its entrance, bounded by the eastern and nothern coasts of China, and by those of Tartary and Corea, dependent on that empire, no fairer occasion could offer for penetrating into it, and adding so much to marine knowledge, without creating suspicion, or giving offence, to the court of Pekin; since the avowed and justifiable object of the mission led directly through it. Besides, nothing could be more expedient than to pursue this route in preference, on the present occasion, to that of landing at Canton, in the southern extremity of the Chinese empire, and proposing to proceed from thence, through the interior of the country, to the capital, at the distance of about one thousand and four hundred miles. For it was, certainly, more desirable to prevent than to experience the delays which, in so long a journey, the Embassador might be made to undergo; the obstacles that might be thrown, purposely, in his way; and the intrigues, for which so long a journey would afford ample opportunities. Such vOL, I. 
Preparations intrigues were to be expected on the part of the magis-
for the Embassy. trates and inhabitants of Canton, from their apprehension that the Embassy would, eventually, affect the situation of the former, on a representation of their oppressions, or the profits of the latter, in their exclusive tracle with foreigners.

To every branch of the sea service Captain, now Sir Erasmus Gower, was known to be fully equal. Independently of the military exertions of this spirited and able officer, he had, twice, at an early age, been round the world, having suffered, and materially contributed to surmount, the vast variety of evils incident to such perilous and protracted voyages; by which his mind was inured to, and provided with resources against, the accidents of untried routes. At Lord Macartney's desire, he was appointed to the command of the Lion man of war, and gratified with the choice of his own officers, whom he selected from a personal knowledge of their merit. Numberless applications were made to serve under him upon the present interesting occasion; and young gentlemen, of the most respectable families, glowing with all the ardour and enterprise of youth, were admitted in the Lion, considerably beyond the customary complement of midshipmen.

A military gnard was allowed, also, to attend the person of the Embassador, as practised in Eastern embassies ; seldom, indeed, for the purposes of safety, but as adding 
dignity to the mission. Lord Macartney's guard was not numerous, but consisted of picked men from the infantry, as well as from the artillery, with light field pieces, the rapid exercise of which, agreeably to the recent improvements, together with the various evolutions of the men, might, in these respects, convey some idea of the European art of war, and be an interesting spectacle to the Emperor of China; who is said to pride himself as a conqueror of extensive territories, and of many Tartar tribes. It was, however, an indispensable precaution, to determine on maintaining strict discipline among these men, with a view, especially, of preventing them from committing excesses of any kind; which, of however slight consequence elsewhere, might appear so scandalous in the eyes of the orderly Chinese, as to confirm the prejudices, already imbibed, against the English.

This object was secured by putting the guard, chosen for this purpose, under the command of an attentive and good officer, Major, now Colonel, Benson; assisted by Lieutenant, now Gaptain, Parish ; and Lieutenant, now Lieutenant Colonel, Crewe. It will appear, in the course of this work, that Captain Parish, who is a very able draughtsman, has contributed to the gratification of the curiosity of the public, by the sketches he took of some remarkable objects throughout the route. There were, indeed, attached to the Embassy, a painter and a 
Preparations draughtsman by profession, of whose merit sufficient
tortte Embassy. specimens will accompany the present publication.

In Doctor Gillan, the Embassy was provided with a skilful physician: a circumstance desirable, not only for persons destined to pass through a variety of climates, but also, from the consideration that, after his arrival in China, the successful exercise of his profession among a people, supposed to be far behind Europeans in every kind of science, might excite their admiration as well as gratitude; and, thus, contribute to advance the general purposes of the mission. The Doctor was likewise deeply versed in chemistry, which being the foundation of many of the arts most useful in society, the knowledge of it capacitates for judging and comparing to what degree of perfection they are carried in the different countries where they are attempted. Doctor Scot, a gentleman of abilities and experience, was appointed to be surgeon, having long served in that capacity in the navy.

Doctor Dinwiddic and Mr. Barrow, both conversant in astronomy, mechanics, and every other branch dependent upon the mathematics, were likely to be useful upon such an expedition as the present.

Mr. Acheson Maxwell, who had formerly resided in India with Lord Macartney, and was much in his confidence, was taken from one of the public offices to sere, now, as Secretary to his Lordship, in conjunction 
with Mr. Edward Winder, a young gentleman from the university.

Mr. Henry Baring, lately appointed a writer in the East India Company's service, was allowed to accompany the Embassy to Pekin, as qualified to improve his residence there, to the purpose of becoming afterwards more serviceable to his employers, at Canton.

In the train of the Embassador, also, was a page, of years too tender not to have still occasion for a tutor, who was a foreign gentleman of parts and erudition; and, it will be seen that, neither he or his pupil proved useless to the public.

It is to be regretted, that to this list cannot be added any professed naturalist, who might have made the most of the opportunities for observation, which such a voyage afforded. The youngest of the party was, perhaps, the least ignorant in this respect. Mr. Afzelius, a Swede, then in England, and eminent for his knowledge in most branches of natural history, was once intended to be employed on this occasion; but he, already, had engaged himself to go to the new settlement at Sierra Leone, on the coast of Africa.

The zeal of naturalists was not, however, wanting; and two botanic gardeners were provided, one at the public charge, and one at the expence of an individual of the Embassy, for the purpose of collecting specimens 
Preparations of whatever productions nature might furnish in the
for the for the
Embassy. course of the expeclition.

One office more was still vacant, which was as necessary, as it was difficult to fill up; that of Chinese interpreter and translator. No man, capable of that employment, then existed throughout the British dominions. From what is mentioned in the first chapter, less surprise will be felt that the supercargoes of the English East India Company return, after several years residence in China, without having made any proficiency in the language. One man, Mr. Flint, who had been an exception to the rule, and continued his attachment to the country, tho he had been imprisoned, and afterwards banished by the Chinese government, for attempting to reach Pekin, was lately dead in England. Another, of the name of Galbert, a native of France, who had long resided at Canton, where he applied with great assiduity to the acquisition of the Chinese tongue, was to have been employed as interpreter on a preceding occasion; but died before the present.

It was by no means advisable to depend on finding fit persons at Canton for serving in that capacity. Some of the natives there had just enough of an European language, either Portugueze or English, to interpret for foreign merchants, in mere matters of sale and purchase; but would be embarrassed to make out a conversation 
upon any other subject; nor is the dialect of the Chi- Preparations nese, usually spoken by them, intelligible at Pekin; and Embassy. experience had taught to doubt as much of their fidelity as of their knowledge. Recourse, therefore, was rather to be had to a search upon the continent of Europe, for such trust-worthy persons, returning from China, as had happened to acquire the language of the mandarines, during their residence in that country; or for the few Chinese who had left it, and had since learned any of the European languages; if either such were, any where, to be found. It was known that, of the missionaries who are publicly tolerated at Pekin, under the immediate protection of the Emperor, it seldom happens that any are, afterwards, allowed to leave the country; but others, who penetrate in disguise into it, have occasionally returned home. Some Chinese men of letters had found their way to Rome, where they were employed in the care and examination of Chinese books and manuscripts in the Vatican; and zeal for Christianity had founded a college at Naples, dedicated to the education of young Chinese, whom the European missionaries contrived to get away from China.

Among all these, whether any were fit and willing to be employed, upon the present occasion, was, indeed, uncertain; but it was the best resource. And, accordingly, the intended Secretary of the Embassy set out in 


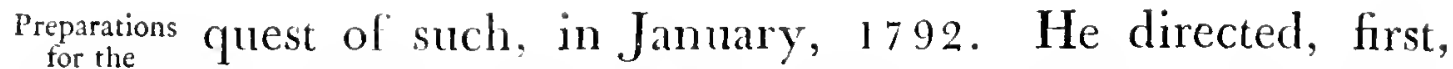
Embassy. his route to Paris, where two foundations for foreign missions still subsisted, the Maison de Saint Lazare, and the Maison des Missions Etrangeres. The former was said to contain, at that time, none who had ever been in China. At the Missions Etrangeres was one, who had returned, near twenty years before, from thence. He retained but a faint remembrance of the language, and was not disposed to visit that distant country again, upon any terms.

It was necessary, therefore, without delay, to pursue the journey, at a most inclement season, over the Alps, to Italy. Tho it happened that the learned Chinese of the Vatican were no longer in existence, a visit to Rome was, in other respects, of use. By the means of Cardinal Antonelli, prefect of the congregation for propagating the faith, letters of powerful recommendation were obtained to the Italian missionaries in China, as well as to the curators of the Chinese college at Naples. On arriving, soon after, at this capital, the college was found to contain several young men from China. Some had already resided in that college many years; and the Latin and Italian languages were sufficiently familiar to them. Due care had been, at the same time, taken, that they should not, by disuse, forget their own: they being all intended for the priesthood, and to be sent back to undertake the cure of the souls of their coun- 
trymen, of the same faith, as well as to endeavour at Preparations persuading others to embrace it. A few having com- Enbassy. pleted their education, and, being in sacred orders, were ready for embarkation; but the curators of the college, true to the purport of its original institution, and watchful, like matrons against temptations in the way of young persons under their care, were particularly cautions by what conveyance to trust their pupils, lest any circumstance should happen, in the course of it, to divert them from their pious destinations.

By the assistance, however, of Sir William Hamilton, his Majesty's minister at Naples, who had on some former occasion obliged the college, and of Don Gaetano d'Ancora, a respectable Neapolitan in the confidence of the curators, every scruple was removed; and two Chinese, of amiable manners, and of a virtuous and candid disposition, as well as perfectly qualified to interpret between their native language and the Latin or Italian, which the Embassador understood, accompanied the Secretary of the Embassy, on lis return to England, in May, 1792, in order to embark for China.

They began, early, to be of use in suggesting, from what they knew and recollected of their own country, some of the fittest preparations for an expedition thither. In the choice of presents, according to Eastern manners indispensable, for the Emperor and his court, vol. I. 
Preparations they mentioned what they thought might be most
forthe Embassy. acceptable. On this head something, also, was to be collected from what was known to be in the greatest demand, and to bring the highest profit, at Canton. Extraordinary pieces of ingenious and complicated mechanism, set in frames of precious metal, studded with jevels, and producing, by the means of internal springs and wheels, movements apparently spontaneous, had, often, borne excessive prices. They were, indeed, of no sort of use; but the imagination of the governing mandarines had been struck by them; and an intimation often followed to the native merchants to procure them, no matter at what price. This mandate it was dangerous to disobey; and the machines were afterwards accepted, formally, as gifts; or a sum, small and disproportionate to the cost, was given in return for them, in order that the transaction might have the appearance of a common purchase. Toys of this kind, or sing-songs, according to the corrupt jargon of Canton, to the enormous value of, at least, a million of pounds sterling, were, in this manner, introduced by private traders into China. Most of these expensive articles found their way, finally, into the palaces of the Emperor, and his ministers. Having been obtained by the mandarines of Canton for little other consideration than the promise of protection to their inferiors, they were, after a short time, transmitted without reluctance, by them, to Pekin, 
in the hope of thereby securing the favour of their Preparations superiors.

It would have been vain to think of surpassing, in public presents of this kind, either as to workmanship or cost, what had already been conveyed to China through private channels; and it was to be hoped that the momentary gratification, produced by those gaudy trifles, had been satiated by the accumulation of them. But it was thought that whatever tended to illustrate science, or promote the arts, would give more solid and permanent satisfaction to a prince, whose time of life would, naturally, lead him to seek, in every object, the utility of which it was susceptible.

Astronomy being a science peculiarly esteemed in China, and deemed worthy of the attention and occupation of the government, the latest and most improved instruments for assisting its operations, as well as the most perfect imitation that had yet been made of the celestial movements, could scarcely fail of being acceptable.

Specimens of the best British manufactures, and all the late inventions for adding to the conveniences and comforts of social life, might answer the double purpose of gratifying those to whom they were to be presented, and of exciting a more general demand for the purchase of similar articles.

The East India Company appointed one of the 


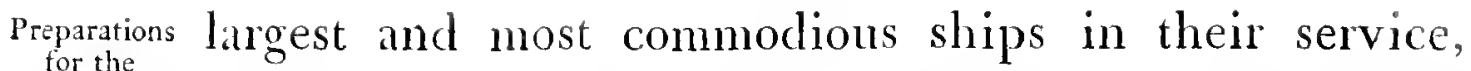
Embassy. under the command of an experienced and judicious officer, Gaptain Mackintosh, to carry out those presents, together with such persons, belonging to the Embassy, as could not be conveniently accommodated on board the Lion. A smaller vessel was, also, provided as a tender. Intelligence being frequently conveyed from foreign ports to China, an account of these preparations could not fail of reaching it before the Embassador.

It became proper, therelore, to take an early opportunity of announcing the Embassy, regularly, to the Chinese government: thus securing the effects of first impressions; lest, otherwise, the undertaking might, through error or design, be made to assume a warlike or suspicious appearance, and the Embassador's reception, thereby, be rendered dubious. Three commissioners had lately been selected by the East India Company, among their most approved servants, to regulate their affairs at Canton. To these it was entrusted to communicate, there, with due solemnity, the intended mission of Lord Macartney, and to deliver a letter, expressive of this intention, from Sir Francis Baring, then Chairman of the Court of Directors, in so public a manner to the Viceroy of Canton, as to prevent the possibility of its being kept from the knowledge of the Emperor, if such should be the Viceroy's inclination.

In this letter Sir Francis stated that, " his most gra- 
" cious Sovereign, having heard that it had been ex- Preparations

"pected his subjects, settled at Canton, should have

"sent a deputation to the court of Pekin, in order to

"congratulate the Emperor on his entering into the " eightieth year of his age, but that such deputation had

" not been immediately dispatched, expressed great " displeasure thereat; and, being desirous of cultivating " the friendship of the Emperor of China, and of im" proving the connection, intercourse, and good corres" pondence between the courts of London and Pekin, " and of increasing and extending the commerce be" tween their respective subjects, had resolved to send " his well-beloved cousin and counsellor Lord Macart" ney, a nobleman of great virtue, wisdom, and ability, " as his Embassador Extraordinary and Plenipotentiary "to the Emperor of China, to represent his person, and "to express, in the stongest terms, the satisfaction he "should feel if this mark of his attention and regard " should serve as a foundation to establish a perpetual "harmony and alliance between them; and that the "Embassador, with his attendants, should soon set out " upon the voyage; and, having several presents for "the Emperor, from his Britannic Majesty, which, "from their size, and nicety of mechanism, could not "be conveyed, through the interior of China, to so "great a distance as from Canton to Pekin, without the " risk of damage, he should proceed, directly, in one of 
Preparations " his Majesty's ships, properly accompanied, to the
for the Embassy. "port of Tien-sing, approaching, in the first instance, " as near as possible, to the residence of the Emperor " of China." And Sir Francis ends the letter by "re" questing the information, thus given, to be conveyed " to the court of Pekin, trusting that the Imperial orders " would be issued for the proper reception of the King "of Great Britain's ships, with his Embassador and " suite, as soon as they should appear at Tien-sing, or " the neighbouring coasts."

The presents mentioned in that letter were, indeed, so choice and valuable, as, to some persons, to denote a very extraordinary purpose. The members of the diplomatic corps, who consider it as a duty incumbent upon them to be alive to every transaction of the government where they are directed to reside, were particularly attentive on this occasion. One of these, who still held to the exploded prejudice of the jealousy of commerce, not being, it seems, aware that the world was wide enough for all who chose to embark in that kind of life, and that it flourished best by reciprocation, failed not to attribute to the British administration, and East India Company, a design of engrossing the total trade of China, by the exclusion of all other foreigners; and proposed a counter cmbassy, to avert the evil. So far, however, was the impracticable project of an attempt at a monopoly of the Chinese commerce removed from the mind of 
those, who thus were suspected of it, that the republic Preparations of the United Provinces being then in alliance with Embassy. Great Britain, and coming next to it in the proportion of the traffic carried on with the Chinese, a communication of the intended Embassy was expressly made to the states general of that republic, with offers of service, to be performed by the Embassador, in case that any circumstance, in the commercial position of the Dutch factory at Canton, should call for his particular interposition.

The general scope of the present mission cannot, indeed, be better ascertained than by his Majesty's private instructions to his Embassador, signified to him through one of the Secretaries of State; in which it is observed, that "a greater number of his subjects, than " of any other Europeans, had been trading, for a "considerable time past, in China; that the commer" cial intercourse between several other nations and " that great empire had been preceded, accompanied, " or followed, by special communications with its "sovereign. Others had the support of missionaries, " who, from their eminence in science, or ingenuity " in the arts, had been frequently admitted to the fami" liarity of a curious and polished court, and which " missionaries, in the midst of their cares for the pro"pagation of their faith, were not supposed to have " been unmindful of the views and interest of their 
Preparations " country; while the English traders remained un-

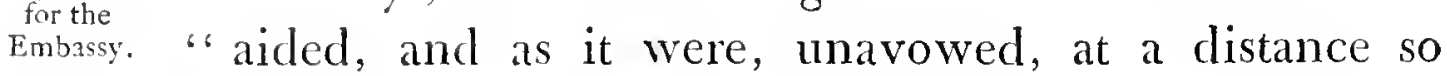
" remote as to admit of a misrepresentation of the na" tional character and importance; and where, too, their " occupation was not held in that esteem, which might "be necessary to procure them safety and respect;" that, " under these circumstances, it became the dignity " and character of his Majesty to extend his paternal " regard to these his distant subjects, even if the com"merce and prosperity of the nation were not con"cerned in their success; and to claim the Emperor "of China's protection for them, with that weight "which is due to the requisition of one great sovereign " from another;" that, "a free communication with a " people, perhaps the most singular upon the globe, " among whom civilization had existed, and the arts " been cultivated, through a long series of ages, with "fewer interruptions than elsewhere, was well worthy, "also, of being sought by the British nation, which " saw with pleasure, and with gratitude applauded, the " several voyages undertaken already, by his Majesty's " command, and at the public expence, in the pursuit "of knowledge, and for the discovery and observation "of distant countries and manners;" but that, "in "seeking to improve a connection with China, no "views were entertained except those of the general "interests of humanity, the mutual benefit of both 
"nations, and the protection of commerce under the Preparations

"Chinese government."

In the same spirit, it is said in his Majesty's letter to

the Emperor of China, that, "the natural disposition of "a great and benevolent sovereign, such as his Im" perial Majesty, whom Providence had seated upon " the throne for the good of mankind, was to watch "over the peace and security of his dominions; and to "take pains for disseminating happiness, virtue, and "knowledge among his subjects; extending the same "beneficence, with all the peaceful arts, as far as he "was able, to the whole human race." That his Britannic Majesty, " impressed with such sentiments from "the very beginning of his reign, when he found his "people engaged in war, had granted to his enemies, " after obtaining victories over them in the four quar"ters of the world, the blessings of peace, upon the " most equitable conditions;" that, " since that period, " not satisfied with promoting the prosperity of his " own subjects, in every respect, and beyond the ex"ample of all former times, he had taken various "opportunities of fitting out ships, and sending, in "them, some of the most wise and learned of his own "people, for the discovery of distant and unknown "regions; not for the purpose of conquest, or of en"larging his dominions, which were already suffici" ently extensive for all his wishes, nor for the purpose vol. I. 
Preparations " of acquiring wealth, nor even for favouring the comEmbassy. "merce of his subjects; but for the sake of increasing " the knowledge of the habitable globe, of finding out "the various productions of the earth; and for com"municating the arts and comforts of life to those " parts, where they lad hitherto been little known; " and" that " he had since sent vessels, with animals "and vegetables most useful to man, to islands and " places where, it appeared, they had been wanting;" that "he had been still nore anxious to inquire into "the arts and manners of countries, where civilization " had been improved by the wise ordinances and vir" tuous examples of their sovereigns, through a long " series of ages; and felt, above all, an ardent wish to " become acquainted with those celebrated institutions "of his (Ghinese) Majesty's populous and extensive "empire, which had carried its prosperity to such a " height, as to be the admiration of all surrounding "nations." That " his Britannic Majesty being then " at peace with all the world, no time could be so pro" pitious for extending the bounds of friendship and " benevolence, and for proposing to communicate and " reccive the benefits which must result from an un" reserved and amicable intercourse between such great " and civilized nations as China and Great Britain."

The object of the Embassy was, indeed, so little conlined to mercantile concerns at Canton, that Lord 
Macartney had discretionary authority to visit, beside Proparations China, every other country (in that division of Asia tor the which may be termed the Chinese Archipelago,) from whence-utility or important information was to be derived; and he had, accordingly, embassadorial powers addressed to the Emperor of Japan, and the King of Cochin-china, as well as a general commission to all princes and states, where he might have occasion to touch in the Chinese seas.

At length, every thing being ready, and the ships at Portsmouth, all those, who were to accompany, or attend the Embassador, to the amount of near one humdred persons, including some musicians and artificers, beside soldiers and servants, joined his Excellency there in September, 1792, in order for embarkation; and meeting all together, perhaps, for the first time. They were, in future, to compose, in effect, one fitmily united by a common destination, and by the ties of interest and duty. Independently of those whose thoughts were concentrated in "the care of living," and who were passive and indifferent to all things else, the rest might be considered as entering into a new period of existence. They had just quitted their former stations, oldest habits, and most close comnections, to engage in a hazardous, but interesting, enterprize. They were not Argonauts, indeed, actuated by the hope of obtaining a golden fleece; but, impelled by 
Preparations the strong incentive of curiosity, and eager to indulge
for the Embassy. the spirit of enquiry, they already contemplated China at a distance, while objects and topics, occupying the attention, and agitating the minds, of those about them, and formerly their own, seemed to lose the interest they had hitherto excited; and a more captivating, tho distant prospect, appeared rising from the horizon to take posscssion of their thoughts.

They, thus, willingly withdrew from the consideration of Europe, and its events; and felt no regret, except where the affections of nature intervened, when it was announced that the wind and weather were favourable for departure. 


\section{GHAPTER III.}

PASSAGE TO MADEIRA. NOTICES OF THAT ISIAND.

$\mathrm{T}_{\mathrm{HE}}$ Lion and Hindostan, having on board the Passage to Madeira. Embassador and his suite, set sail from Portsmouth on the 26th of September, 1792, as did also the Jackall brig intended to serve as a tender to the Lion. At this season of the year, when the earth's relative position to the sum occasions equal day and night throughout the globe, and the change of the sun's declination is most rapid, a sensible effect is frequently produced, likewise, upon the atmosphere, in which sudden and violent commotions, termed equinoctial gales, render navigation, at this period, more hazardous than at any other. But the degree of improvement to which the nautical art is brought, at present, and the expertness and hardihood of those who practise it, enable them to combat, successfully, tempests happening at a distance from the shore, wherever, according to the marine phrase, there is plenty of sea room; and leave them little apprehension, at any season, if the moment of setting off be fair.

The course of the voyage to China, immediately from Portsmouth, leading, in the first instance, through the British Channel to the westward, required a wind, 
Passage to which is observed to blow there less frequently than
Madeira. $\underline{\text { Madeira. }}$ others, and for a shorter continuance. Sir Erasmus Gower availed himself of such a wind, thercfore, as soon as it took place; and the Embassador, anxious to have the whole benefit of it, to clear the Channel, resisted his inclination, notwithstanding the invitation sent to him to stop at Weymouth, where their Majesties then were, with most of the royal family. The weather, however, did not long continue moderate: the ships, in the darkness of the night, soon lost company of the tender, and they were, themselves, forced to take shelter in Torbay. In the delay of a couple of days here, which an adverse wind made necessary, the arrangements for the future voyage were made, to the general satisfaction.

They, who measure the inconveniences to be felt in traversing the ocean in modern times, by the specimen of what most persons, not accustomed to the sea, often suffer during their passage in small and crowded packets, between England and the Cintinent, would be agreeably disappointed on embarking in such ships as were now in the service of the Lmbassy, where every comfort was provicled. In the Lion, notwithstanding its being burthened with the baggage and usual incumbrances of travellers, as well as with warlike stores, and those required for navigation, likewise every article of sustenance for four hundred men, including passengers and 
crew, for a considerable time to come, together with the materials requisite to prepare such articles for use, yet room was left for procuring several of the advantages of a dwelling upon land. A considerable space was allotted, and distributed into regular apartments, and separate chambers, for the principal passengers and officers, where they might partake of society, or withdraw to privacy, at their option; and the deck formed an open area, sufficiently spacious and convenient to allow the enjoyment of air and exercise. Even that sickness, so little dangerous, but so excruciating, to which persons first going to sea are subject, particularly in small vessels, is less felt in those of considerable size, and in fewer instances. It, generally, happens likevise that men bound on a distant expedition, conscious of the length of time during which, tho they are constantly moving forward, they are to move in the same vehicle, dispose their minds to render it as pleasant to themselves as possible, as well as to be reconciled to what they cannot alter for the better.

It must be confessed, indeed, that landsmen, reflecting on their situation when at sea, may be sometimes conscious of their inferiority to those, under whose direction they have placed themselves, on this new element. Unacquainted with the structure of the capacious and complicated machine that holds them, and on whose solidity and successful movements depends 
Passage to the preservation of their lives, as well as their arrival
Madeira. Madeira. at the place of their destination; idle and unintelligent spectators of the methods and efforts practised to forward and regulate those movements for the common good; necessarily passive and obedient to those who understand and act upon the occasion; they may, at times, regret their own temporary inutility, and dependence. Such impressions, however, probably, are slight and transitory; and scarcely damp that happiness of which a passenger's life at sea is certianly susceptible. Whatever was his situation before he quitted land cannot be amended, now, by the further application of his thoughts to the means of effecting such an alteration; and the train of his labours and solicitudes, at least, suspended, his mind experiences that calm and rest, to which it had, perhaps, been hitherto a stranger. Now satisfied with receiving and communicating the gratifications of social converse, or partaking in any amusement which fancy may suggest; without being disturbed by the common cares and ordinary incidents of the voyage; and implicitly confiding in the skill and diligence of those to whose management it had been cntrusted; as little affected by the apprehension of calamities, to which all voyages are liable, while no accident intervenes to present danger to the imagination, as by the consciousncss of mortality in the fullness of health; he is entircly open to the enjoyment of the 
present hour; until the view of other shores shall sti-

mulate to fresh pursuits, and agitate again his breast with hopes and fears.

Of the passengers in the Lion and Hindostan, very few felt severely from sca sickness, notwithstanding the roughness of the weather. A distinction appeared, upon this occasion, in the temperaments of men, which nothing in their appearance could have previously denoted. The two gentlemen, who were now most sick, were of an adult age, of a frame sufficiently robust, had generally been healthy, and had already been at sea; while another, the honourable Mr. West, who was going in the Lion, in his way to try the climate of Madeira for a consumption, to which he has fallen since a victim, was not affected by the utmost motion of the ship. None of the midslipmen, tho they had no other lodging, by the regulations of the navy, than that of swinging in hammocks over the coilings of the cables, near that part of the ship which is called the cockpit, and where hot and confined air, and even, sometimes, noisome scents, might be apt to provoke nausea in the stomach, seemed to suffer from sea sickness; tho some of them were of very tender years, now on their first voyage, and of a constitution apparently delicate. They, probably, were preserved, in some measure, from every complaint, by their extraordinary activity and exertions in the performance of their new duty, and by the vol. I. 
Passage to elevation of their spirits, on being liberated from the
Madeira. Madeira. shackles of a school, and gratified with a subordinate authority in the ship. They were the first to ascend the tops of the masts, or to clamber on the beams, called yards, suspended across them, holding only by a rope, and in such apparent peril, that a young spectator, reflecting on the quick alarms of maternal tenderness, exclaimed, in the language usually spoken to the Ghinese interpreters, - si matres nunc viderent! were their mothers to see them in that posture!

On the first of October the ships set sail again, taking their last departure out of England, from Torbay, and stretching over from the hilly coast of Devonshire, came soon within view of Britany, and the flat isle of Ushant, after which they saw, for nine days, no land. However usual such a situation is to every navigator, since the invention of the mariner's compass, it is an awful spectacle to him, who gets into it for the first time; and the mind contemplates, with some degree of admiration, the ingenuity of man, in applying the quality of a particular fossil (which under a certain form, and properly suspended, points always towards the same portion of the heavens) to the purpose of directing his way through the trackless ocean. When out of sight of land a pleasurable sensation is always felt on meeting with other vessels. Several were perceived availing themselves of the same wind to go different 
routes; but the English having then no enemy to ap-

prehend or to attack, the progress of the present voyage was not impeded by efforts to approach to, or avoid them; and Sir Erasmus Gower continued to steer, with favourable gales, in a direction parallel to, tho not in sight of Spain, Portugal, the Straits of Gibraltar, and the northern part of Africa.

Sir Erasmus observed, that "all ships, bound from "Europe for the island of Madeira, will discover that " their way is influenced by a current, or set, from the "Western ocean into the Bay, formed between Ushant " and Cape Finisterre, and into the Mediterranean, and, " as well as his observations, in five visits to Madeira, " could enable him to ascertain, such current should be " estimated to set south-east, about eleven miles in fifty " leagues."

The ships, steering their course agreeably to this estimate, and assisted for the correction of the log reckoning, as to longitude, by several time-keepers and lunar observations, found themselves on the tenth of October in sight of the islands of Porto Santo and Madeira. When abreast of Porto Santo, Madeira appeared as one great mountain, whose summit was hidden in the clouds. Shortly, afterwards, appeared three very small islands, called the Desertas, of which the two most distant were little better than pointed rugged rocks. The third, called the Table Deserta, was elevated, but 
Passage to flat, and in some state of cultivation. Near it is a sin-

gular rock rising perpendicularly out of the sea.

Sir Erasmus advises " all ships bound for the island " of Madeira to endeavour to make or steer for Porto "Santo, and then proceed for the Brazen-head, or east" ern point of the road of Funchal, the capital of the " island, by going between it and the Desertas, off the " northernmost of which is a high rock frequently "mistaken for a sail. The passage is about nine miles "wide, but without soundings, except in very deep " water, close to Madeira. The latitude of the road is " thirty-two degrees thirty-seven minutes thirty seconds " north, and the longitude, ascertained by several eclip"ses of the satellites of Jupiter, and by an eclipse of the "sun on the fourth of Jume, 1788 , is seventeen degrees "five minutes west of Greenwich. The compass had " eighteen degrees thirty-five minutes variation to the " westward of the pole. The tide flows, at the full and " change of the moon, north-north-west and south-south" east; spring tides rise perpendicularly seven feet; " neap tides five feet. The flood sets to the eastward; " the regulations of the port require all ships, before, "or immediately on anchoring, to send to acquaint " the governor of the island with an account of what "they are, and their reasons for stopping there. Men "of war are not to send their boats to vessels coming "into the road, until they are visited by the pratique- 
" boat, or boat whose business is to enquire lest any " infectious disorder should be on board. The same is

" to be observed respecting vessels that are departing, " which are not to be boarded after the visiting officer " has been to search for natives leaving the island " clandestinely, and for prohibited goods: English men " of war salute with thirteen guns, after receiving an "assurance of a return of an equal number. " Ships' boats may land on the beach during the "summer montlss; but when there is no landing of " goods to make it necessary, it is better to be avoided, " at all seasons, both for the safety of the boats, which " are driven by a violent surge on a shingly shore, and "for preventing the common men from having the op" portunity of frequenting the disorderly houses in the " neighbourhood of the beach, and drinking the per" nicious spirituous liquors vended thereabouts. The " landing near the Loo rock, being defended from the "surge, is very safe and easy; and tho there are cot" tages near to it, the boat's people may casily be kept "from them. Caution is necessary, likewise, against " the shore boats coming on board, under pretence of "selling fish, fruits, and vegetables; for their chief ob" ject is the sale of the worst spirituous liquors, and "often concealed goods. Fresh beef, water, and vege" tables are to be procured here for the ship's company, " and are sent on board in boats belonging to the place. 

Passage to "The British government allows the contractor five
Madeira.

"shillings a ton for water, and sixpence a pound for "beef, for the use of the crews of his Majesty's ships " of war. The contract wine is of a weak quality, and "will not keep: and the price is sixteen pounds for a "ton, containing one hundred and twenty gallons. A " fleet of twenty sail of men of war may be amply sup" plied with refreshments here, if their stay should not " exceed ten days.

"The road is open from the west to the south-south" east. The winds blow strongest here from south-west "to south-east. Ships obliged to anchor in the winter " in Funchal road should be very attentive to the dark "gloomy appearance of the weather to the southward, " with a swell setting in; for it is very dangerous re" maining at anchor with those prognostics."

It has been thought a harbour might be constructed, tho at a considerable expence, by uniting the Fort de Itheo, commonly called the Loo castle, with a rocky neck of land that jets into the water towards it, distant about one liundred and twenty yards. 'The depth of water, through this narrow passage, is from six to seven fathoms: so that it would require an immense mass of stone work, of which the materials are, indeed, at hand, to withstand the heavy sea, which almost perpetually tumbles in when the wind is blowing from the southward; and which has frequently been known to break 
over the Loo castle, a height presumed to be no less Madeira. than eighty feet. Such a harbour would, indeed, contain but a very few vessels, beside the craft employed in carrying commodities from the capital to the smaller ports, and bringing from thence to it the produce of the island. During the stormy season, those vessels moor within the Loo rock, and are secured by additional cables to the shore; and thus, when tempests threaten, they are entirely left to take their chance, being quitted by the crew, who seek refuge upon land.

The island of Madeira, at first view, appeared rocky, barren, and uncultivated; but its beauties expanded to the eye on a nearer approach; and nothing could be more picturesque and inviting, than the appearance of Funchal and its adjacent hills, when observed from the ships at anchor. The town is situated in the midst of a verdant valley, in which churches and other buildings, white on the outside, being interspersed, make an agreeable contrast with the ever-green trees and plantations. Spring and summer may be said to be the only seasons, as it is known that the cold or heat here are seldom so great as to be unpleasant. During the Embassador's stay, Fahrenheit's thermometer was from sixty-nine to seventy-two degrees, in the shade, at noon. It is seldom found to exceed seventy-five degrees in the autumn, in the middle of the vintage; and, in January, it is about sixty-four in Funchal, tho the tops of the hills, in sight 
Madeira. above it, are then covered with snow. The ships having left England in the beginning of October, when vegetation, in some instances, already began to fade, and to announce the speedy droop of nature, its wild luxuriance in Madeira was the more striking to natives of northern regions, landing, so soon afterwards, on that island. The whole creation seemed there alive. Myriads of insects were buzzing in the air; swarms of lizards moving along the ground in every direction. Scarcely a plant without fruit or flower; every tree in leaf; some of the humble herbs of Europe growing here into the habit and size of shrubs. Nothing appeared languid or declining, except, perhaps, man might be so considered. Most of the common people had dark complexions, forbidding features, were under the middle size of Europeans, with little of the spirit and activity of the original inhabitants of Africa, or of the colder parts of Europe. The offspring of the latter, transferred to southern countries, often become, it seems, enervated and listless.

Every honour and attention, due to the representative of a friendly and powerful sovereign, was paid, by order of the Portugueze Governor, to the Embassador, as well on board the Lion, as on his going ashore, and after he was landed. His Excellency declined a military guard; but yielded to the solicitation of the Governor to partake of an entertainment, which was indeed 
sumptuous; and to which also were invited, beside the Madeira. gentlemen in the suite of the Embassador, and officers of the Lion and Hindostan, the merchants of the British factory, the chief officers of government and of the garrison, and several of the principal inhabitants of the island, in all about two hundred persons; but not one lady was present, except, in the beginning, the Governor's daughter, about ten years old, who was dressed in all the formality of a woman, and did the honours of the table without embarrassment; and at the desert, which was laid out in fresh and cool apartments, when the Governor's wife presided, she being too much indisposed to be present at the whole entertainment. She was addressed by the name of Donna Louisa, and her daughter by that of Donna Maria, it seeming to be the custom of the Portugueze of rank, to use only the baptismal name preceded by a title, tho they bear several surnames. The Governor had those of Pereira, Forjas, and Coutinho, probably belonging to the most distinguished families from which he was descended.

In the hall of the government house was painted the popular and interesting, but doubtful, story of the first discovery of Madeira by an Englishman, called Robert Macham, who lived towards the end of the reign of the third Edward. This man, it is said, of obscure birth, had fallen in love with a young damsel, called Anne d'Arfet, of exquisite beauty, and of a noble family, vor. I. 
Madeira. which, disdaining so low an alliance, tho Macham had gained her affections, obtained a warrant from the king to keep him in a prison, until the lady was persuaded to marry a nobleman, who took her immediately to his seat near Bristol. Macham, sometime afterwards, being released, found means to convey the lady on board a vessel provided to carry them to France. A storm suddenly arising, and the ship being ill manned, they were driven far to sea, and tossed, for thirteen days, at the mercy of the waves, out of sight of any land. At length, however, they thought they descried something like it, which redoubling their efforts to approach, they perceived an island, overgrown with wood. The vessel was soon at anchor; and Macham and the lady, with a few attendants, went on shore, and sought shelter by building a kind of hut under the branches of a large spreading tree. In the course of the night a tempest drove the vessel from her anchors, and carried her to the Barbary coast, where she was wrecked, and the seamen made captives by the Moors. The lady was so affected by this fresh disaster, that she died in a short time; and Macham, through grief, soon followed her. Their attendants, rendered desperate by the loss of their conductor, quitted the island, and betaking themselves to their open boat, put out to sea, without knowing even what course to steer. After a series of adventures, these men fell in with a Spaniard, who, delighted with 
their story, communicated it to Gonzales Zarco, sent by the king of Portugal on a voyage of discovery, and preMadeira, vailed upon him to sail in search of the island. However imperfectly its situation had been described by the English sailors, it was in a little time found out by him.

The particulars of this story have, indeed, the testimony of Alcafarado, a contemporary author, who, at the instance of Henry, Prince of Portugal, composed a book entitled, A Relation of the first Discovery of the Island of Madeira ; but De Barros, the Livy of the Portugueze, ascribes it entirely to Gonzales Zarco and Tris$\tan$ Vas.

Another native of Great Britain, Mr. William Johnstone, lately a merchant in Madeira, who joined the pursuits of science to the avocations of his profession, by an union less rare in the present than in any former age, made a geometrical survey of this island. He found it to be in the form of, nearly, a parallelogram, the mean length of which, from west-north-west to east-southeast, was about thirty-seven miles, and mean breadth eleven miles, containing an area of four hundred and seven square miles, or two hundred and sixty thousand four hundred and eighty acres. It is divided into thirty-seven parishes, and is said to contain about eighty thousand inhabitants; so that there are near two hundred persons for every square mile, and, on an average, 
Madeira. every individual might possess upwards of three acres of land.

A great part of Madeira, however, seems incapable of cultivation; the sides of the hills being steep and rugged, and almost destitute of soil. The waters, in their descent from the mountains, form a number of narrow vallies, in all of which small patches of cultivated ground appear, and in many of them pleasant little villages are situated. The sides of the hills are so thinly covered with soil, that necessity has compelled the cultivators to endeavour to add to it, by breaking such pieces of the scattered rock, as contain vegetable matter, into smaller parts, over which the rills, from the heights, being made to flow, the fragments soon are found to crumble and become a fertile mould. This is, perhaps, the strongest instance of their industry. Indolence is predominant, particularly with the men; who often lie basking in the sun, or stretched at their length upon their floors, while their wives and daughters are sent to the distance of some miles, up the mountains, to cut down broom, which they carry in loads to Funchal, where it is bought for fuel. These women, notwithstanding the roughness of the roads, travel constantly barefooted. The poorness of their food, consisting chiefly of pumpkins and salt fish, added to the severity of their labour, and the warmth of the climate, give them the appearance of age at an early period of life. 
The chief produce of the island is the grape, from Madeira: which are made, annually, upon an average, nearly twenty-five thousand pipes of wine of one hundred and twenty gallons each; half of which is exported to England, North America, and the East and West Indies; the remainder is consumed by the natives, in its original state, or in that of spirit distilled from it. The grape of Madeira is generally white, and produces a juice of the same colour; but there are others which yield a deeper coloured juice, forming a red wine, called Tinto, of which a mixture with the former, in a small proportion, serves to give it a darker tinge.

There is, likewise, a red skinned grape, called Bastarda, of which the juice is white. In some few soils another grape is raised, remarkably rich and sweet, from which is produced the celebrated Malmsey wine. Of this the average quantity made is said to approach five hundred pipes, and sells at about sixty pounds a pipe. Of the other wine, which, in contradistinction, is called dry or hard Madeira, the highest price charged, when new, to dealers in that article, seldom exceeds thirty-two pounds a pipe. From other persons, according to the custom in every branch of trade, a larger sum always is demanded. For old wine an addition of twenty shillings a pipe, or more, is made for every year it has been kept, as an equivalent for leakage, evaporation, and interest of the capital remaining unemployed. 
Madeira. The average price on every kind of wine is fourteen pounds, or thereabouts; and reduces the whole export value considerably under two hundred thousand pounds; part of which serves to pay for manufactures from Great Britain, flour and salt fish from America, and corn from the western isles, belonging, as well as Madeira, to the crown of Portugal.

It is not uncommon for the merchants of Madeira to purchase British goods, brought there, at the rate of twenty-five per cent. profit on the original price, as set forth in the bill of parcels. The bill, indeed, is sometimes altered in the passage between England and Madeira, and higher prices annexed, as having been paid for every article. This unwarrantable practice is so well known, as to have given the name of salt-water invoices to such fabricated accounts; by which, however, the consumers are the only sufferers, as the Madeira merchant puts, generally, the same proportionate advance, beyond what he pays, on the commodities he has for sale.

The government of Portugal imposes a duty upon all imports into Madeira, except provisions, as well as upon wine exported; and levies, likewise, internal taxes: yet the whole is said to net no more than eight thousand pounds, after all the civil and military expences are defrayed. The profits, accruing from that island, are undoubtedly more considerable to Great Britain than to 
its parent state, in consequence of the trade carried on to it, and the British factory settled in it, consisting now Madeira. of upwards of twenty commercial houses, and whose acquired fortunes centre in Great Britain. Other nations share but little with them in the Madeira trade. Even the Portugueze, who have attempted to vie with them, are seldom found to prosper, having, it is supposed, less commercial knowledge, as well, probably, as a smaller capital and credit, and fewer foreign connections.

The British merchants attach to their interest the cultivators of the vine, by supplying in advance to all their wants, in the intervals of the vintage, and in the seasons when it fails. Their dealings with the Portugueze inhabitants of Funchal must also be extensive; independently of which, there does not appear much social intercourse between them.

Enough, however, has subsisted to introduce, among the latter, those associations of affected secrecy, called fraternities of Free-masons, which in England are devoted, certainly, to good fellowship, and, frequently, promote the purposes of charity; but in countries where, from the nature of the government, freedom of conversation is constrained, such societies may favour, from the privacy of their meetings, an unreserved communication of sentiment, rendered, on that account, suspicious. 
Madeira. The Roman Catholic clergy, observing the fervour of devotion slackened among the laity, to the degree of rendering it difficult to recruit their convents with proper subjects, were apt to attribute so alarming a decline of zeal to the propagation of free-thinking among Freemasons, and applied to the arm of the inquisition for their punishment and expulsion. A persecution ensued agdinst many of the principal Portugueze resident in Madeira, which was likely to be attended with very serious consequences, had not the present minister of foreign affairs at Lisbon, the Chevalier de Pinto, a man of a liberal mind, and much in the confidence of the Prince of Brazils, regent of the Portugueze dominions during the indisposition of his mother, procured an edict, by which it was ordained, that "all the inquisitors "and judges of the tribunal of the inquisition should, " as soon as any information were given to the said tri" bunal, immediately investigate the same; and, when " the culprit was in custody, should appoint advocates "for the defence of the aforesaid culprit; and whenever " sentence should be pronounced against him, the pro" ceedings should be sent, immediately, under cover, " to the secretary of state, Don Jose de Scabra, in order "to be presented to the regent, that his highness might " determine thereupon what he should think fit; and "that the proceedings should be so sent within two " months after seizure of the culprit, it not being the. 
"regent's intention that any Portugueze subject should Madeira. "suffer for years in a rigorous prison."

The spirit that dictated this edict, as well as the provisions it contains, are found sufficient to arrest the tyranny of the inquisition. Nor is it upheld, as formerly, by the superstitious attachment of the people: even the women are said to be less religious. None have taken the veil in Madeira during the last twenty years. The influence of the Portugueze clergy was formerly without bounds: they governed every private family. Something of this sway was still perceptible at the governor's entertainment, where a forward and drunken friar walked round the tables, commanding attention, and impertinently interfering, without interruption or reprimand.

The British factory has always been protected against any attacks of the inquisition; and is on good terms with the governor and chief judge, to each of whom a small salary, by way of compliment, is allowed, out of a contribution levied, by the factory, on the freight of goods from England, and on wine exported by them. This contribution is authorized, in part, by an act of the British parliament, and partly by an internal regulation of the factory, and serves to support such British seamen, as happen to be left through sickness, or any other accident, on the island, as well as to pension such YOL. I. 
Madeira. of its own body, as shall have, through misfortunes, declined in their circumstances.

The commercial houses in Madeira are all open for the reception of the passengers, stopping for refreshments there, in their way to Asia or America, if they bring the slightest introduction from any friend in Europe; and when the ships arrive in fleets with many passengers, there is a continued round of entertainments and festivity: the houses are spacious in proportion. Hospitality of this kind, so little known in crowded European cities, at the same time that it brings business to the merchant, is peculiarly grateful to strangers landing from a voyage; and often an intimacy quickly ensues between the host and guests, to be suddenly, however, broken off by a call announcing the departure of the ships; and with little likelihood of being renewed, as Madeira lies far out of the track of the same persons on their return home.

Amongst the food most relished at Madeira, is the hog; these agimals are permitted to range wild amid the mountains, when young, after being marked by their respective owners; they feed on nutritious roots, frequently of the fern; and are aficewards hunted and caught by $\log s$.

In the neighbouring isle of Porto Sinto, partridges, with which that island abounds, are caught alive by 
the inhabitants, stationing themselves round where the Madeira. covies spring, and chasing them on all sides, until the birds, alarmed wherever they attempt to rest, are at length exhausted with fatigue, and suffer themselves to be taken by their pursuers.

No noxious animal is known to exist in Madeira; no serpents, whether venomous or innocent; no hares, or foxes: no oysters or herrings on the coast; other fish not rare. But the greatest consumption among the poor is of the salted cod, imported from America. Its excessive use contributes, it is supposed, together with other bad provisions, to the scorbutic eruptions on the skin, so common among the lower orders of the people here. They are much afflicted, also, with rheumatisms. The middle and higher classes are subject to paralytic affections, supposed to be occasioned by indolence, repletion, and want of sufficient exercise. The small-pox is said to be most dangerous in summer; inoculation is rare on account of religious scruples. Intermittent fevers are not known upon the island, where, indeed, there are no marshes to produce them; the country is too hilly, and high winds are too frequent, to admit the stagnation of noxious vapours; the gusts, coming down the mountains upon the town of Funchal, are so violent as sometimes to unroof the houses; to prevent which, recourse is had to the awkward shift of placing heavy stones upon the tiles, without attending to the 
Madeira. danger of their rolling off upon the people in the streets. This peril, or any other, does not, however, deter gallants from giving, according to the custom of the mother country, nightly serenades under the latticed windows of the fair.

The town, notwithstanding the advantage of streams ruming down the streets, is not kept clean. It is, in other respects, improving. An almeycla, or mall, with handsome rows of trees, has been lately finished there, through the influence of the present governor. He, sometimes, has encouraged other buildings, by procuring subscriptions for that purpose, from the principal Portugueze inhabitants, as well as the foreign merchants; in the payment of which the latter, only, are found punctual.

The town is said to contain about fifteen thousand people. The population and cultivation of the country are upon the increase. The seasons, however, are uncertain, and the crop, sometimes, fails; the expence of tillage thus brings the farmer, occasionally into debt; but the laws of the country, tho they seize the property of debtors, do not retain their persons in confinement.

The culture of the sugar cane, as more congenial to tropical climates, is in a great degree abandoned in Madeira. The cane grows here to the height of about cight feet, and in form resembles a common reed, with a jointed stem, and leaves springing from the joints. 
The middle of the stem furnishes the best and sweetest juice. There were also a few trees of the true cinnamon, with three-ribbed scented leaves, and a thin fragrant bark.

In an excursion to the eastern part of the island, by some gentlemen of the Embassy, from Funchal, the road was found, in the beginning, to be steep and craggy up the hills; afterwards, it was confined to a narrow path, bounded on one side by a perpendicular rock, and open on the other to a dreadful precipice. The path is, indeed, in many parts impassable, except to those who go on foot, or ride on mules well trained to travel over it, and who are perfectly sure-footed. The party arrived, at length, upon an open plain, adomed in many places with the flowering myrtle and box tree, growing wild, and the whortleberry shrub, which, tho in England it does not exceed in height the diminutive heath growing in its neighbourhood, is here become a bush of no inconsiderable size. At the east end of the island they saw the crater of an extinct volcano, about four hundred yards in diameter, around the sides and in the bottom of which, were scattered fragments of the lava. In the rainy season the waters had lodged in the bottom of this crater; but it was at this time dry, and almost entirely covered with the herb penny royal.

To Doctor Gillan it appeared that "there had been 
Madeira. "several craters in the island, and that eruptions had "taken place from them at various and very distant " intervals. This was particularly manifest at a place " near the Brazen-head, where might easily be counted " twelve different eruptions of lava from a neighbouring " crater. The strata, or layers of lava, were all distin"guished from each other by the following regular " arrangement: first, the bottom part was hard solid "lava, scientifically termed, compact lava; secondly. " over the layer of compact lava, lay a layer of cellular "lava; thirdly, next came the scoria, partaking of the "nature of pumice stones; and, lastly, the volcanic " ashes. The second eruption lay arranged in the same "order above the first; and every other, to the twelfth "eruption.

"A deep excavation furnished in one place an op"portunity of observing, that the bottom rock, on "which the first layer of compact lava rested, was "chiefly an iron ore, composed of calx, or mineral of "iron and of clay. From which circumstances it was " inferred, that this rock had never been exposed to " any high degree of heat; otherwise the iron would "liave been fused, and, by its specific gravity, would "liave descended to the lowest part, and left the loose "clay upon the surface; and, also, that the layers of "superincumbent lava had flowed from a crater of a " date more recent than the formation of the ore. It 
"would be difficult to coneeive how these appearances Madeira.

" could have been produced, had the whole island, " originally, been formed by volcanic fire, and thrown " up from the bottom of the ocean. It contains, indeed, " much matter which has not undergone, or, at least, " bears no marks of, the action of fire. Beside the iron "ore, already mentioned, quartz undecomposed and "very compact has been in several places found, and " high up the hills.

"The chain of the highest mountains of Madeira has "hardly any volcanic appearance. The clouds enve"lope, frequently, their tops, and from them descend "all the streams and rivulets of the island. Their " antiquity is marked by the deep chasms or gulphs "they have formed, in their descent, between the " ridges of the rocks, during the long lapse of time " they have continued to flow. In the beds of these "rivulets are found pebbles of various sizes, and large " rounded masses of silex, such as are usually found in "the beds of many similar torrents in the Alps. The " soil, also, of the fields and pasturage grounds appears " exactly the same as those of the continent, where no "volcanic fire has ever been suspected. It is likewise " to be observed, that no lava of a glassy nature has " been discovered in Madeira, nor any perfect pumice "stone; circumstances, which both indicate, that not "the highest degree of heat had been suffered here: 
Madeira. " but it is probable that the bay or beach of Funchal is " a segment of a large crater, the exterior part of which " has sunk into the sea; for, in the first place, the shin"gles or blue stones upon the beach are all of compact "lava; secondly, tempestuous weather throws always " upon the shore larger masses of the same blue lava "stone, and, also, a quantity of cellular lava, approach" ing to pumice stone in texture, but much heavier, "and not fibrous; and lastly, the Loo rock, and landing " place opposite to it, to the westward of Funchal bay, " as well as that on which the Fort St. Jago is con"structed, are evidently perpendicular fragments of "the edges of the crater, which have hitherto resisted "the action of the sea, by having been better sup" ported, or having more closely adhered together, tho " much worn by the violence of the surge. They bear " not the leasi resemblance to the neighbouring rocks a " little within shore."

As far, indeed, as every external appearance and every examination into the bowels of the earth can warant a reasonable conjecture, the body of the island of Madeira may be considered as the summit of a primary mountain, fron whence, at several subsequent periods, volcanic matter was exploded; and the smaller islands of P'orto Sarto and the Desertas were, originally, joined to it; but have, in the varieiy of convulsions whicil mature has undergone, been separated from it, 
and the intermediate spaces have been covered with the Madeira. sea.

The rocky shore of the island of Madeira, and the violent surge, constantly beating on it, form a natural defence against invasion. What art has added at the capital, which extends three quarters of a mile along the beach, and nearly half a mile in depth, consists, as Captain Parish observed, " in four small forts. One " situated at the eastern extremity of the beach of Fun" chal, with a perpendicular height rising immediately " in its rear. This fort stands so low as to be exposed to " the fire of shipping; altho an opportunity offered of "occupying an height close to it, where might be " erected a very commanding work. This fort is called "St. Jago. That of St. Lorenço, within two hundred "yards of the western extremity of the town, is an "irregular work, whose greatest length is about one "hundred yards, and its breadth nearly as much. It " has three small bastions and a battery toward the sea, " and flanking the beach. This is occupied as the resi" dence of the governor. A third, called Peak castle, is " situated at the north-west angle of the town, upon a " hill, distant about half a mile from the shore. It is very " difficult of access from the southward; but if the hill " above it were once gained, no formidable resistance " could be expected from it, as it is completely over"looked. The fourth fort stands upon the Loo rock, roL. I. 
Madeira. "higher than the largest ships, but by no means suf"ficiently so, to warrant the disposition made upon its "summit. The guns are crowded together en barbette; " and the little parapet, over which they look, appears - unequal to resist a cannon shot.

" The beach may further be defended by a direct "line of musquetry from a low line built wall, on " which a few guns are mounted at intervals, and " which has occasional projections that afford small "flanks. This line appears inadequate for defence, " when troops are covered, in their landing, by men of "war; but the constant surge, upon the beach, would "prove a powerful assistant in obstructing the manage" ment of boats in an attempt to land. It is said that a "very convenient landing-place may be found about "two miles to the westward of Funchal bay, round the "Pico de Cruz, perhaps at Praya. From hence two "roads lead directly to Funchal; one ascending the hill "for a short distance, then descending into the valley " under the Peak castle, from which it is enfiladed. "The other keeps the shore, and would, perhaps, be " preferred, as less exposed to the fire of the Peak castle, " and as being sheltered, in a great degrec, by the in"tervening buildings, from the fire of St. Lorenço. "The line wall, extending from the sea to the height " on which is situated Peak castle, is not of a bet"ter construction than that of the beach. and, being 
" destitute of cannon, would make but a feeble resistMadeira.

"ance. The Peak castle seems to afford the principal

"defence; it is well built, and in tolerable repair. Its "walls are of a considerable height: but it has no " ditch; and it is completely commanded from the rear. "About twelve gums are mounted on it, of different "calibres and constructions, generally, very old guns. " of English make. Such, too, are all the cannon of " the place; and their carriages are quite out of repair. " Most of the merlons are of stone, generally, from two " and a half to three feet thick. In the Peak castle " there is a small armory, containing about one hundred "and fifty stand of arms, and three brass field pieces of "English construction.

"The forces on the island are, of regulars one hun"dred and fifty artillery, and as many infantry; with "two thousand nilitia, who are occasionally under " arms. They are formed into two battalions, and are "obliged to clothe themselves in uniforms: also, ten "thousand irregular militia, who are not so clothed or " exercised; but who, on consideration of their being " at no expence on that account, are obliged to repair "highways, to take charge of the signals, and to do " duty in the garrisons. They are divided into three "districts, each commanded by a colonel; and subdi"vided into companies, with a captain and lieutenant s" to each.", 
Madeira. The regular troops are partly composed of natives of Angola, a Portugueze settlement on the coast of Africa. They are pressed into the service from among the most idle and disorderly inhabitants of the place. Angola is, as well as Madeira, one of the vast number of the conquests achieved, or discoveries and settlements made, in Africa, Asia, and America, by the subjects of one of the smallest and weakest kingdoms now in Europe; but under the auspices of the most enterprizing princes that history has recorded. Their remaining possessions are so scattered throughout the ocean, that there will be yet occasion to stop at some of them, in the course of the present voyage.

It is necessary for ships bound on a distant expedition, especially men of war, whose crews are so much more numerous than those of merchant vessels, to touch, on account of health, occasionally, at different places on their route, in order to procure fresh meat and vegetables for the people, and to recruit the stock of fresh water, and of wood for fuel. These objects were attained for the Lion and Hindostan within a single week. The Jackall tender, which lost their company in the Channel, had not, indeed, yet joined them. But the Embassador was desirous to pursue his route without loss of time. His Excellency and the gentlemen of the Embassy, intent upon the object of arriving soon in China, quitted, with less regret, their anıusements, 
and acquaintance, and the continuation of their en- Madeira. quiries, in Madeira. And, instructions being left for the Jackall to proceed without delay to Port Praya in the island of St. Jago, they embarked from Funchal on the eighteenth of October, 1792. 


\section{CHAPTER IV. \\ PASSAGE TO TENERIFFE; TOST.JAGO. NOTICES OF THOSE \\ I SLAN DS .}

Passage to
Teneriffe.

are several clusters of islands, and of rocks, besides those mentioned in the preceding chapter, situated in different degrees of latitude, and near enough to the continent to be, by theorists, supposed to have, at a vastly remote period, been joined to it; and they may still be considered as appendages, in some sort, of it.

The first cluster, which occurs in a southerly course from Madeira, consists of little more than rocks, called the Salvages, and are carefully to be avoided. Within one day's father sail, lie those islands which are generally understood to be what the ancients called the Fortunate Isles, from the abundant productiveness of the soil, as well as the salubrity and delightfulness of the climate. They have since changed that significant appellation, tho without losing their good qualitics, to that of the Canary Islands; and they now belong to the crown of Spain.

Next to them in succession come, tho at a considerable distance, the Cape Verde islands, so called from their 
vicinity to a continental cape of that name; which cape and islands are subject to Portugal. One of these is St. Jago, where, according to Sir Erasmus Gower's directions for the Jackall tender, she was to follow him; and, in order to allow her more time to overtake him there, as well as for the purpose of procuring a supply of better wine for the seamen of the Lion, than Sir Erasmus could get in Madeira at the contract price, he determined to touch, in his way to St. Jago, at the town of Santa Gruz in the island of Teneriffe, one of the Canaries.

The course thither was due south, sometimes, and always southerly: in this course the weather was sensibly growing warmer; and the passengers and crews, tho in respect of time approaching to the winter months, felt as if winter were flying from them. The winds, which hitherto since the ships left England, as well as there, were variable, began gradually to partake of that steady and uniform direction from the eastward, which denote the regular trade winds, so contrary to those which are the emblem of change.

The effect of the wind's impulsion upon ships is known to be measured by the simple contrivance of a thin, flat and triangular piece of wood, which continuing motionless in the sea wherever it is thrown, whence it is called a $\log$, marks, by the celerity of the ship's recerling from it, how quickly she is driven by the wind. If a greater progress be found to have been 
Passage to made, than is denoted by this admeasurement, the dif-
Teneriffe. Teneriffe. ference proves a current or progressive motion of the sea, independently of the agitation of its waves, which, from whatever cause it may proceed, is found frequently to take place. Sir Erasmus Gower observed, in proceeding to Teneriffe, a constant current setting to the southward, at the rate of a third of a mile an hour, equal to twenty-two miles in the distance between that island and Madeira.

Gaptain Mackintosh, of the Hindostan, "who had " made twenty passages in this route, generally experi" enced a current from the thirty-ninth degree of lati" tucle to that of the Canaries. In this part of the ocean " he formerly found, from repeated and accurate obser" vations, that this current set three degrees fifty mi" nutes east-sonth-east. He found it strongest opposite " to the entrance into the Mediterranean, or Straits of "Gibraltar; and in one voyage, the current was com"puted by his time-keeper to set about forty miles a "day. This current inclines more southerly as it ap"proaches to the Canaries. It strikes on the coast of "Barbary, and takes, about Cape Bojador, different and "opposite directions, near in shore, one part running "to the northward towards the Mediterranean, and the "other to the sonthward, along the coast, towards the "Equator."

On the twentiech of October the island of Teneriffe 
was perceived by the people of the Lion, appearing through the haze. The ships did not approach the land till the afternoon of the next day, and it was found that the island, when first observed, was eighteen leagues distant from the ships. The Peak, or utmost top of Teneriffe, vying in altitude with the highest lands of the ancient continent, did not appear, as the ships approached from the north-east, to answer to the idea of that lofty eminence, which the imagination was prepared to find. The towering hills, indeed, which are close to it, on that side, took away from its apparent height ; but a passenger on board the Lion, remembering to have seen it, from sea, on the opposite or south-west side of the island, describes it as rising perpendicularly from the ocean, marking its elevation by three successive ranges of light clouds, like streaks across it, one above another, between each of which it was distinctly perceptible, until, at last, it hid its summit in the uppermost of them.

Sir Erasmus Gower observes, that " the north-cast of "Teneriffe, called Punto de Nago, appeared, at about " four leagues distance, to be a steep bluff point, very " like the Brazen-head going into Funchal, except that "it is higher. The land, to the north or north-west, was " rocky and very irregular, with perpendicular peaks, "and three rocky islands, of a middling lieight, de"tached, near a mile, from the main land. When the vol. I. 
Passage to "ship was nearly abreast of the north-east end of the Teneriffe. "island, its southern extremity was perceived sloping "very gradually to a low point, known by the name " of Punto Prieta. The island, called the Grand Canary, " was seen lying to the south; and, to the south-east, the "road and town of Santa Gruz, in Teneriffe, seven or " eight miles from Punto de Nago. Tho that point " looked like a rugged rock, the other hills had trees " and verdure to their very tops." Sir Erasmus Gower mentioned, that "the Lion anchored in twenty fa"thoms, the south-east point of the island open, a " sail's breadth, with the castle point bearing south" west by west, and the north-east end of the island " east by north half north, distance off shore about one "quarter of a mile.

"The anchoring ground is, in general, very bad; it " is advisable, therefore, for ships that call at this place, " in the winter months, merely for the purchase of re" Creshments, not to come to an anchor, but to stand off " and on, sending a boat on shore, to go through the " necessary forms with the governor, and to order the "supplies to be put on board. The little additional "trouble, and seeming inconvenience of this mode, are " sufficicntly made up by the preservation of the cables, " the salety of the ship, and exemption from anxiety. " Even in the summer montls it is necessary to buoy " the cables, and to moor with as little cable as possible. 
"The place is defended by batteries and a line of mus- Tenerife.

" quetry towards the sea; the shore is fenced with rocks "and large stones; and the surge is constantly so high " as to render it almost inaccessible to boats. There is " a good mole or pier, projecting into the sea, where "boats may land in all seasons; at its extremity is a "battery of four brass guns. The pier is likewise de"fended by a well built square fort, which appears in "good condition. About eighty yards to the southward " of the pier is a creek among the rocks, where goods "are landed in mild weather. There are forts and " small batteries to the northward and southward of the " mole, extending half a mile each way. They are all " of them close to the sea shore. The force of each is "from two to four guns. The militia consists of all "persons capable of bearing arms in the island. The " regular troops, including artillery, do not exceed three " hundred men."

Beside the defences of art, and those already mentioned to be furnished by nature, another arises from the evident danger to which hostile ships must be exposed, as the wind is scarcely ever favourable to get away from the land, and escape the fire of the batteries on shore, in case of failure of success. To this danger did the gallant Admiral Blake, in the desire of doing his country service, render himself liable, in a war with Spain, in 1657, when he attacked a fleet of 
Teneriffe. Spanish galleons, lying in this road, nearly equal to his own in strength, independently of the powerful protection from the shore. Tho he actually succeeded in destroying the whole of the enemy's ships, and, by a sudden and uncommon change ol wind, was enabled to bring all his own off sale, it is difficult to view the scene of action, and consider the circumstance, generally, occuring there, without joining to the admiration of the bold attempt and successiul event, some portion of the anxiety which is felt for a peril still impending. "The latitude of the road of Santa Cruz was ob"served, by Sir Erasmus Gower, to be twenty-eight " degrees twenty-eight minutes north; its longitude, "by the time-keeper, sixteen degrees twenty-six mi" nutes west of Greenwich, and the variation of the " compass seventeen degrees thirty-five minutes to the " westward of the pole. The tide rises perpendicularly " six feet.

"According to the regulations of the port, there "should be no communication between the ships and "shore, from the setting to the rising of the sun. It is, "also, prohibited to frre the morning or evening gun " on board; tho it was done by a small French frigate, "then lying in the road, under the national colours. "English men of war do not salute, because the Spa" niards are forbid to make a return. Beef, mutton, " pork, goats, pouluy, fruits. and vegetables are very 
"good and reasonable; and, for ships bound to the Teneriffe.

"southward and requiring refreshments, this place has " many advantages over Madeira ; particularly the wine, " to be had by contract for the ship's company, is of a "much stronger quality, and at a much cheaper rate. "A pipe, containing one hundred and twenty gallons, " does not exceed ten pounds."

The shipping of the necessary supply of wine, for the Lion, was likely to take up two or three days; and several of the passengers from that ship, and some passengers and officers of the Hindostan, took the opportunity of this delay to go on shore, in order to visit as' much of the island as they could. The town of Santa Cruz, which is pleasantly situated, did not present to them the crowds of people, or scenes of business perceptible in Funchal; but it appeared better laid out, more open, cleaner, and more comfortable. The wellbuilt pier stretched out into the sea, the conveniences contrived for safe and easy landing near it, the handsome almeyda, or mall, along the quay, shaded with several rows of trees, the fountain adorned with marble statues in the square, all apparently of late construction, denote a government attentive to the improvement of the place. The hills, above Santa Cruz, are neither so high, nor overhang so immediately the town, as those behind Funchal, which, as being the last place that the present party visited, was now more readily the 
Teneriffe. object of comparison in their minds. They found the walks and rides, in the neighbourhood of Santa Cruz, more level and agreeable; they seemed to breathe a lighter, purer, air than usual, and felt they were in a fortunate island. Of these feelings there could not be a more lively instance than in the concurring expressions of regret, which fell from every mouth, that Mr. West, in whose recovery every one took interest, had not come on, to take the benefit of a climate so seemingly superior to that of Madeira where he staid.

Mr. Hickey " ascended the craggy mountains to the " northward of the town, in hope of getting an advan"tageous view of the Pcak, but was prevented by the "clouds with which it was wholly enveloped. The "rocks upon those hills appeared to be volcanic; and " among them a variety of natural caves were formed, "which serve for places of occasicnal rest, and shelter, "to the labouring people in the season of cultivation. "The culture is carried up to the tops of these moun"tains, the soil being supported, in successive stages, "by walls or heaps of stone. A peasant, whom $\mathrm{Mr}$. "Hickey met, with a fowling-piece in his hand, and " with whom he conversed in Spanish, informed him, "that the produce of these mountains was corn, beans, " and a grass which scrved as fodder for the cattle. At "this scason nothing remained, except dry stubble. In "the adjacent hills, some very singular combinations 
"appeared of craggy heaps and cliffs, and, below, a Tencrifie. " tremendous precipice. A variety of wild odoriferous " herbs were scattered around; and some, of a powerful " and forbidding smell. La Figuera de India, called " commonly in English the prickly pear tree, bears " here a valuable fruit, not easily, indeed, to be plucked "or eaten. But the obliging peasant, already men"tioned, overcame the difficulty by means of a tuft " of grass, with which he enveloped the fruit, to guard " his fingers from the prickles with which it was co"vered; and, cutting cautiously away the rind, laid " open the pulp, which was very agreeable to the taste, " uniting the flavour of the fig, the winter burgundy " pear, and the water melon. The pcasant, in the " course of conversation, mentioned, as a received opi" nion, that the island contained rich mines of gold, "but that the King of Spain had ordered the search for " them to be discontinued, lest, as the peasant added, "they should prove a temptation to the English to " render themselves masters of the island."

The principal party from the ships proceeded another way into the country; and after a ride of a few miles, upon the slope of a considerable hill, arrived at the capital of the island, called St. Christophé de Laguna, where, however, no lagoon or lake remains. Here still are held the courts of justice, tho the governor now resides at Santa Cruz. The chief inhabitants of the prisons 
Teneriffe. of the capital were young females, of the lower classes of society, who were accused of incontinency; the temptations to which crime the softness of the climate renders them little capable of resisting, notwithstanding the rigour with which it is pursued by the ecclesiastical jurisdiction.

In the markets was a profusion of red grapes, scarcely any white, tho the wine, exported from Teneriffe, be generally of the latter colour. The season of the vintage is always that of cheerfulness and activity, and the people, in the streets, seemed to partake of such a disposition. This city is situated on an eminence, in a fertile plain of considerable extent. Beside vines, it bears wheat, Indian corn, potatoes, and a species of bean not unlike a lupin. From grounds, still higher, water is conveyed to a variety of fountains in Laguna, as at Santa Cruz, in an aqueduct composed of wooden troughs, and supported by poles fixed into the earth.

To the plain, above mentioned, succeeded a ridge of hills, of gentle ascent, from the summit of which were easily traced the windings of a pleasant valley, stretching to the westward, along the feet of a range of hills that separate it from the sea coast. The town of Ticoronté, and numerous little villages, formed a scene agreeable and picturesque. The bosoms of the mountains were all well cultivated; and their more rugged sides were chiefly covered with the spontaneous plants of 
warm regions, such as the botanists call the Cacalia reneriffe.

Kleinia, the Agave Americana, the Cactus Tuna, beside others of little ornament or use.

A heavy shower of rain overtook the travellers, amid these mountains, a little before noon; and one of the inhabitants of a village, where they took shelter, told them that a similar shower falls about the same hour there almost every day throughout the year.

From thence the party descended towards a rich and extensive vale, lying between an amphitheatre of mountains and the sea. At the bottom of these mountains, out of which rises the Peak of Teneriffe, is the villa or city, and about three miles distant, on the sea coast, is the puerto or seaport, of Orotava. The first is inhabited, chiefly, by persons of landed property in that neighbourhood; and at the second is carried on a considerable degree of commerce, principally for the exportation of wine. It is, chiefly, as at Madeira, in the hands of a few British commercial houses, which import, in return, the manufactures of Great Britain.

The consumption of British goods, in the remotest places, among the Spaniards, as well as the Portugueze, easily accounts for the vast demand from the warehouses of London, and seems to render that capital, in a commercial sense, the metropolis of the world.

From Orotava the ascent of the mountain, towards the Peak of Teneriffe, is generally attempted. The time 
Teneriffe. of the year, late in October, was, indeed, unfavourable . to such an undertaking. The cold, in the mountains, at this season, was described by the natives, in the neighbourhood, to be intolerable; and snow and hail now fell frequently with such suddenness and violence, as to overwhclm those who were exposed to them. Still, however, the ascent was not declared to be impossible. If the two succeeding days, at the expiration of which it was necessary to join the ships at Santa Cruz, should luckily prove fair, and the weather calm, the object, it was hoped, might be attained. The opportunity, to the same persons, would not probably recur; and they determined to try their chance: deeming the progress they might make, however inconsiderable it should prove, towards the summit of the mountain, a gratification superior to what any other excursion could afford.

The morning of the twenty-third of October was serene, and promised a good day. Fahrenheit's thermometer, near the sea side, was at seventy-six degrees in the shade. The huge cone of the Peak, towering above a bed of fleecy clouds, seemed to overhang the city of Orotava, tho at the ristance of several miles. The party set out, about noon, and proceeded for some time through a pleasant vale, mostly covered witlı vineyards, which produce a sweet and agreeable wine: they soon began to ascend the mountain, along the sloping side of a deep valley, almost entirely covered with a grove of 
large chesnut trees. On the edge of the momtain were Tenerife. thinly scattered a few solitary huts, partly, hid in the thick shrubbery which surrounded them. After passing the valley of chesnut trees, the party presently arrived at the summit of the first, called the Green, mountain, on which there was a level plain of considerable extent, covered with heath growing several feet high, and interspersed with myrtle, laurel, and whortleberry shrub (vaccinium), all in great luxuriance; but no cultivation was attempted there by man; nor indeed, thereabouts. any human habitation.

At the termination of this plain commenced a second mountain very different, in appearance, from the former. Its steep sides were craggy and barren. The road lay along a dangerous ascent on the brink of precipices. Little verdure appeared but what was afforded by the Spanish broom and cytisus, which seemed to thrive in the rocky surface of lava with which this mountain was almost covered. A few pine trees were thinly scattered on its sides. Several wild goats were found thereabouts, being the only quadruped observed to dwell upon those mountains.

The party continued to ascend, by rugged and narrow paths, depending. chiefly for their safety on the surefootedness of their mules, till they arrived at a watering place in the hollow of a huge rock, under the shade of a solitary pine. Notwithstanding the real and apparent 
Teneriffe. perils of this road, one of the attendants of the party, an artificer belonging to the Embassy, deserves to have his name (of Thibaut, a native of Turin,) recorded, for the instance. he afforded, of inflexible constancy, in adhering to the instructions he received, tho excessively difficult to execute, in such a situation: as a mathemacical instrument maker, and acquainted with the nature of barometers, he was charged with the care of carrying one, intended for the purpose of observing, by the degree of descent of the quicksilver in the tube freed from air, how much the height of the colmmn of the atmosphere, over such part of the same fluid as was exposed to its pressure, was diminished by the elevation of the mountain above the horizon; and, consequently, ascertaining the exact measure of such elevation, or the mountain's height. It was necessary, in order to preserve, for this purpose, the barometer from injury, to hold it in a steady, uniform manner. Thibaut, with his attention fixed entirely to this object, holding the instrument with one hand against his breast, and the bridle loosely with the other, suffered his mule to follow her own pace, without changing his posture, or moving the barometer (whatever were his fears or dangers), on any alarm or accident that occurred.

In an account that is given of the last preceding journey up these hills, with a philosophical apparatus, mention is made of two barometers, which had succes- 
sively been provided, having been broken before they Tenerife. could be used. The present party, by Thibaut's steadiness, were enabled to find that they had ascended, late in the afternoon, near six thousand feet above the town they quitted in the morning. Even such an elevation, tho the weather then was hazy, enlarged, considerably, their prospect, and gave them, as it were, a greater command of land and sea. Some little time before, when the sun was bright, and already behind the Peak, the shadow of the latter, perfectly formed on the ocean, and gradually lengthened, and extending to the horizon, formed a picture, not more uncommon than grand and striking, to the beholders. But now the mountain began to be overcast with clouds; from the hollows which intervened between the basis of the great cone and the second mountain, on which the travellers then stood, arose, rapidly, as if bursting from deep and vast boiling cauldrons, various impetuous gusts of wind, forcing and combating with each other, and seeming to forbid any approach towards them. On this part of the mountain the ascent was by no means steep, but the ground was strewed with volcanic matter; not, however, of that spongy texture on which vegetation, in the form of a lichen, in so few years, appears on the sides of Mount Vesuvius.

Throughout this second mountain, were excavations resembling small craters of extinct volcanoes. It became 
Teneriffe. now more difficult to trace out the usual path, as the evening was set in. The cold began to be unpleasant, the thermometer having fallen twenty-six degrees. The guides and muleteers proposed to halt here for that night, at least; deeming it dangerous to move on. Promises and menaces were used to engage them to proceed; they did so for another hour, in which, however, little progress was effected. It then began to rain, the cold to become more intense, and the wind more violent. But the travellers were yet distant from their intended resting place, usually known by the name of La Estancia dos Ingleses, the resting place of the English. Thither they were anxious to arrive, in order to attain, the next forenoon, if practicable, the summit of the cone. But the guides, who perceived a tempest then approaching, in which they declared the unsheltered traveller, infallibly, must perish, insisted on stopping where they were, under the brow of a projecting rock, which diverted, in some degree, the current of the wind. One of the party tried the experiment of proceeding on his mule, as far as he was able, up the hill; but soon finding it was utterly impossible to resist the impetuosity of the storm, returned to his companions, in order to provide for the night, in the manner the least uncomfortable in their power. They had been supplied with abundance of refieshments from Orotava; but no tent was to be found there to rest in upon the mountain. 
This circumstance, however unpleasant, could not deter Tenerife. them from the undertaking; they had now no other resource than that of strewing the bare ground, near them, with leafy branches of the Spanish broom, by way of beds, to sleep on. There was little shelter from the wind, and none against the rain, which, tho not violent, was frequent. The air also was keen and cold; the thermometer at forty-five degrees; but the branches of the cytisus, growing on this dreary mountain, proved to be excellent fuel, and, tho green, produced, readily, a blaze: the wind, indeed, which blew in eddies, drove the flame, sometimes, to a distance from the travellers' resting place, who lost, thus, its influence in their favour, and, sometimes, turned it to their faces, so near as to scorch them. At times, however, they had opportunities of contemplating, as they lay under the grand canopy of heaven, the awful scene around them. The moon, then in its second quarter, shone, at intervals, very brilliant; the zenith happened to be clear, towards which the Peak upreared its high and tapering point, and, as the eye descended down the slanting sides of that immense cone, it perceived that the base was lost in black rolling clouds, which, whirling impetuously from thence into the vallies far below, reached, at last, the ocean, over which some remained suspended, while others seemed incorporated with its waters. 
Teneriffe. On the approach of day the party rose, little refreshed by sleep, and their clothes dripping with the rain which had fallen upon them. The summit of the mountain, on which they stood, appeared only at a little distance, but the weather was extremely boisterous; and the wind drove with violence heavy drops of rain. The point of the upper cone, or sugar-loaf, was clear, but the large conical frustum, which supported it, was enveloped in thick clouds, rolling, in continued succession, along its sides, and hurled rapidly from thence into the vallies between the hills, against which they were impelled, and quickly condensed into rain.

Of the party some concurred with their guides in proposing to abandon the project of going farther; but Doctor Gillan, Doctor Scot, Mr. Barrow, and Mr. Hamilton of the Hindostan, had the firmness to persevere in the attempt of ascending, still, as high as possible; while the rest turned their eyes, readily, back to Orotava, except, indeed, a boy little more than eleven years old, who, not disheartened by the sufferings of the preceding day and night, saw himself, with evident reluctance, separated from his more adventurous companions, to follow the retrograde steps of the person who had the care of him. Of the two guides, belonging to the party, one conducted the gentlemen going to Orotava, who, as they descended from the mountain, which proved to them so dreary and inhospitable, experienced a most 
rapid change of climate as they approached to the genial Teneriffe. and comfortable atmosphere below; such change being little less than if, in that short space of time, they had suddenly been transported, from the icy coast of Greenland, into the warm latitudes of the Pacific Ocean; so much quicker is the transition, with regard to its effect, in a vertical than in an horizontal direction.

Before these travellers got to the seaport of Orotava, they passed through the city, or upper town, of the same name, neatly built of stone, on an irregular surface. They took the dimensions of a remarkable dragon'sblood tree growing near it; to which tree any of the same kind in Madeira, tho there thought large, were, comparatively, but striplings: its trunk measured, at the height of ten feet from the ground, thirty-six feet in girth; at the height of fifteen feet, this trunk divided itself into about a dozen branches, sprouting regularly, as from a centre, in an oblique direction, upwards, like the subdivisions of an umbelliferous plant, all of equal dimensions, and producing, at their extremities only, thick and spongy leaves, resembling, but much smaller than, those of the common aloe. Concerning this tree there was a tradition, current in the island, that it existed, of no inconsiderable dimensions, when the Spaniards made the conquest of Teneriffe, about three centuries ago; and that it was then, what it still is, a YOL. I. 
Teneriffe. land mark, to distinguish the boundaries of landed possessions near it.

The gentlemen who wished to pursue their journey upwards, were accompanied by the second guide. This man was one of the very few remaining of the descendants of the Guanches, or original inhabitants, and sole possessors of the island, when first invaded by the Spaniards in the fifteenth century. He still retained some characteristics of that ancient race: he was a tall, strong-boned man, little less than six feet high, and walked erect and firm, tho near his grand climacteric, or upwards of sixty years of age; the lineaments of his countenance vere strongly marked; his eyebrows high and arched, his cheek-bones prominent, his nose somewhat flattened, and his lips of a thickness approaching to those of the blacks of Africa.

With this man the four gentlemen, above-named, according to Mr. Barrov's relation, "soon gained the "summit of the mountain from whence the great cone "arose, which, being often covered with snow, pro"cured, among ancient writers, the name of Nivaria "for the whole island. On this summit was another " cxtensive plain, not clothed, like the green mountain, "with perpetal verdure, but loaded with irregular " huge masses of black lava, scattered round, not the "least trace of vegetation being visible on this dreary 
" waste, except now and then a solitary cytisus, peeping, Teneriffe.

" with its feeble and half-withered branches, through " the fissure of the rock. The violence of the wind con"tinued; the rain encreased; and the very apex of the "Peak began to be obscured with clouds. At length, " it became equally difficult, for the mules, to stem the " current of the wind, and for the riders, to kee ptheir "seats.

"They already, however, had ascended about two " thousand feet above the place where they had passed "the night; but now the muleteers became refractory, " and endeavoured to prevent any exertions for forcing "the animals to go on. The cold was piercing (the " thermometer at thirty-six degrees) and together with "the sleet, almost took away the power of holding "steadily the reins. In the course of this tempest, $\mathrm{Mr}$. "Hamilton was literally blown off his horse. Doctor "Scot, who happened to be well mounted, pushed "boldly forward towards the basis of the cone, till he " was lost, to the rest, in the thickness of the mist. "Doctor Gillan endeavoured to follow, but the wind, " actually, forced his mule to the edge of a steep pre" cipice, where, fortunately, she fell into a bed of "volcanic ashes, or both must, inevitably, have gone " down the precipice, and perished. No effort could, "afterwards, stimulate the mule to move forwards a " single step. Another ran under the shelter of a 
Teneriffe. "large mass of lava, where she equally remained im" moveable. The resource, now lefr, was to tie all the " horses and mules to the neighbouring rocks (for the "muleteers and guide had already disappeared) and to "proceed, on loot, along a valley, whose ascent was "gradual, to the botton of the great pyramid, from "whence the Peak arose, as from a second cone. But "the plan, after repeated efforts to proceed, soon proved "to be impracticable. The surface being a continued " layer of light pumice stones and ashes, the body sunk, " considerably, at every step, and a dust issued from "the pressure, emitting a sulphureous and suffocating " smell, which obstructed respiration. The tempest, at "the same time, raged with augmented violence; the "thermometer was down to the freezing point: the " chops of rain fell half congealed, and were observ"ed to have a saltish taste. Under all these circum"stances, the difficulty of getting farther on, to persons " now exhausted, was found to be unsurmountable; "and, having done all that was possible for them, no " alternative remained. They went back to the place " where they left their cattle, whose faces were no " sooner turned down the hill, than they scampered " away at a rate as difficult to restrain, as it was before "to push them forward.

"The party, presently, got into the midst of very "dense clouds, whose contents were discharged upon 
"them in torrents of heavy rain, which fell, without T'eneriffe.

" intermission, during the remainder of the descent, "for about three hours. Soon afterwards the weather " cleared up, and the upper part of the Peak appeared " covered with snow."

"They scarcely had arrived at Orotava when Doctor Gillan was obliged to take to his bed with a fever, occasioned by the fatigues he had undergone; but care and rest, in the hospitable house of $\mathrm{Mr}$. Little, soon restored him. The other gentlemen lost the memory of their sufferings, in the moming, by partaking of a ball with some agreeable English and Spanish ladies, the same evening, in Orotava. The next day the travellers returned to Santa Ciruz.

The excursion to the Peak, which was, at this season, so fatiguing in the attempt, and so impracticable in the execution, occasions much less difficulty or hardship at another. In a manuscript account of a visit to that place, by the same Mr. Johnstone, who is described in the preceding chapter, as having surveyed Madeira, it is mentioned that, being at Teneriffe, in the summer time, and having the opportunity of providing tents and other necessaries for such an undertaking, as well as leisure to go through it without hurry, little was suffered in accomplishing it. His party slept, the night before they attained the summit of the Peak, about the spot which terminated the labours of the succeeding travellers. 
Teneriffe. "There," it is said, "they encamped on ground co"vered with pumice stone, a stream of lava on each " side; in front, a barren plain; the island of Grand "Canary bearing south-east, as if rising out of an im"mense field of ice, formed by the clouds below them. "About four o'clock next morning, the first of August, "the moon shining briglit, and the weather clear, they "began to ascend a kind of path, along the first great "frustum, leading to the smaller and higher Sugar-loaf. "The passage was steep and disagreeable, being covered "with pumice stone, which gave way at every step. "In about an hour they got to the Alta Vista, where it "was necessary to climb over the lava, leaping from "one large stone to another, till their arrival at the foot "of the Sugar-loaf. It was now about half past five. "The horizon, to the south-east, was very clear, and "the rising sun a beautiful object. Here they rested, "on a small flat, about five minutes, but did not allow "themselves to cool, the air being so very penetrating. "They then began to ascend the Sugar-loaf. This "was by much the most fatiguing part; it being ex" ceedingly steep, and wholly consisting of small pu"mice stones, so that the foot, at every step, sinks and "slides back. They were obliged to take breath, re"peatedly. It was little more than six o'clock when "they got upon the summit of the Sugar-loaf. At this "time the clouds had gathered about a mile and a half 
" perpendicular below. They were thick, and had a Teneriffe.

" very striking effect, appearing like an immense extent " of frozen sea, covered with innumerable hillocks of "snow, above which the islands of Grand Canary, "Palma, Gomera, and Hierro or Ferro, raised their " heads. On the sun's getting a little higher, the clouds " clispersed, and opened to the view the coast around. "The colours, hoisted on the Peak, were distinctly " seen, by gentlemen in Orotava, through their tele"scopes.

"The prospect from the Peak is romantic and exten" sive, no other hill being of a height to intercept the "view. The coast is perceived all round, and a distinct " idea of the island formed. The north-rest coast ap" pears to be well cultivated; but the south-east seems "dreary and barren. Within the summit is an excava"tion, or cauldron, not less than eighty feet in depth, " into which the gentlemen descended, and gathered " some sulphur, with which the surface is mostly co"vered. In many parts the foot cannot rest upon "the same spot above a minute, the heat penetrating " quickly through the shoe. Smoke issues frequently "from the earth. Just under the surface is a soft red" clish clay, so hot that the hand introduced into it " must instantly be withdrawn. In the cauldron the "sulphureous odour is very offensive; but on the ridge " it may be easily endured. 
Tenerifie, "From this place they saw the town of Santa Cruz, "and the shipping in the road, which is a distance, in " a direct line, of about twenty-five miles. A second " barometer was here received, to supply the place of " another broken in the ascent. But it was found that " some of the quicksilver had escaped; and, therefore, " no dependence was to be placed on any observations "by it. They continued two hours and a half upon "the summit of the Peak, without feeling any incon"venience from heat or cold. Soon after sun-rise the "thermometer, in the shade, was at fifty-one degrees. "They descended the Sugar-loaf, in a few minutes, " running the whole way, which was found to be the " best mode.

"At the foot of the Peak there were several caverns, " in the midst of lava, some filled with fine water, ex"tremely cold, and frozen at the edges of the caverns. "Others, in the winter, are filled with snow, over "which the sun never shines; and, thus, snow con"tinues in them throughout the year. Here they re" mained till night.

"Mr. Johnstone, recollecting a difference of about "six miles in the calculation of the latitude, as given "by Captain Cook, and as it is laid down in the collec"tion of recquisite Tables for the Nautical Ephemeris, "was willing to ascertain the same; and, taking an ob" servation of a fixed star, found that the latitude was 
"within a mile of what Captain Cook had asserted it to Teneriffe.

" be. Some time before, Mr.Johnstone, when on board " ship in the offing of Orotava, took the angles, made " by a line from the horizon to the summit of the Peak, " at two different spots, and, measuring the distance "between them by the log, determined the perpen" dicular height of the Peak to be two thousand and " twenty-three English fathoms, being nearly the same " as Monsieur de Borda had calculated from a base "measured upon land. From the comparative obser" vations of Monsieur de Borda's barometers, upon the "Peak, and by the sea side, the mountain's height "came within two fathoms of the geometrical mea" surement. Mr. Johnstone computed, likewise, the " distance of the Peak from the seaport of Orotava to " be ten thousand one hundred and eighty fathoms, or, " nearly, eleven miles and a half, bearing south forty" eight degrees west. The variation of the compass was " sixteen degrees to the westward of the pole."

The storm, experienced on the Peak of Teneriffe by the present party, and which impeded their ascent at that time, was felt severely in the roads of Santa Cruz. "The winter appeared to be there set in," as Sir Erasmus Gower observes; "but its approach was considered " premature by at least a month. Several merchant ves"sels drove, or were dragged, from their anchoring " ground, together with their anchors; others parted, YOL. I. 
Teneriffe. "or broke, their cables. The Hindostan lost two an" chors, and, had the gale continned, might have been " in danger of driving against the rocks. The Lion " happened to lie, probably, in the best place; as she " neither drove, nor did her cables suffer any injury, " tho no precaution had been taken to secure them."

At Orotava the only vessel lying in the road was obliged to slip lier cable, as is the practice in bad weather there, especially when the wind blows strongly from the northward. The road is entirely open in that quarter; and the surge drives with such violence against the shore, that a boat can seldom land. The waves have been known to break over the tops of the houses, standing at some distance from the beach; and the wine, exported from thence, is usually shipped by floating off the pipes containing it.

There had been a convenient port, on the north-west coast of the island, called Garrachica, unti] the last eruption from the Peak in 1704, which continued, at intervals, for two months, when, by the volcanic matter. rolling down on that side of the mountain, the port was completely filled up, and houses are now erected where ships rode formerly at anchor.

The hcight of the great mountain of Teneriffe, where the intense cold produces ice in plenty, gives the inhabitants, of the warmer climate below, the opportunity of using that substance to cool the wines for their own 
consumption. This is collected by the peasants, in Teneriffe. winter, near the summit of the Peak, and preserved, in caves, near the Estancia dos Ingleses, where the great cone begins to rise; from whence it is brought, in the summer, to Orotava, and other places on the coast.

Within a mile of the seaport of Orotava is a collection of living plants from Mexico, and other parts of the Spanish dominions in America. From hence they are to be transplanted into Spain. It is an establishment of some expence, and, whatever may be its success, it shews a laudable attention, on the part of that government, to the promotion of natural knowledge.

The exterior practices of devotion, in every dependency of Spain, where the inquisition reaches, absorb, however, much of that leisure which might, otherwise, be employed for the purposes of instruction. Religion seems to be the principal business of the gentry of both sexes. Ladies of rank are seldom seen out of their own families, except in the churches at mass, at matins, and at vespers. The unmarried reside in convents, and are often cajoled to take the veil, by those who are already nuns professed, notwithstanding the bitter repentance which many of these feel for the vows themselves had made.

The escape of an intended victim to devotion made some noise, about this time, in Teneriffe. A young lady, during her noviciate, had, by uncommon accident. 
'Seneriffe. the opportunity of seeing a youth, who inspired her with a passion inconsistent with her former views of religious retirement. Notwithstanding the apparent freedom left to novices to alter their intentions, it is, in fact, as unsafe as it is rare. This young novice manifested no symptoms of reluctance in pursuing her original vocation, and preparations were made for the awful ceremony of taking the last solemn vow to renounce the world.

On such occasions it is the custom to throw open the gates of the convent, in order to satisfy the public, that the ladies within them are equally at liberty to quit it altogether, or to continue within its walls. When the day arrived, which was to seal her doom, and resign her for ever to the cloister, her relations and friends assembled, as is usual, to be present on the occasion. In the crowd of the spectators was the young gentleman, who was disputing with heaven the fair victim. After solemn exhortations from the pulpit, that now the final moment was arrived, when she was to devote herself to God, abandoning all sublunary considerations, as well as all ties of affection or of blood, or instantly to quit the holy place, she then inhabited, for ever, she stretched out her hand to the youth, who advanced quickly to receive it, and hurrying with her directly from the church, while the priests, the nuns, her relations, and the people, stood motionless with astonish- 
ment, the happy pair got soon safely to a place, where Teneriffe. they were married.

The present bishop of the Canary islands resides, usually, at the city of Palmas in Canaria. But his revenues, which are not less than ten thousand pounds a year, are distributed, almost entirely, in acts of charity and beneficence throughout all the islands. To this humane disposition he, however, joins the rigour of ecclesiastic discipline; and encourages the observance of ceremonies of piety, by offers of indulgence to those who practise them. He, who shall kneel publicly before the shrine of San Bernardo in the square of Santa Cruz, and repeat so many times aloud the prayers of Pater noster and Ave Maria, may receive a dispensation exempting him, for forty days, from many of those obligations which the Spanish church, more rigid than its parent Rome, imposes on its votaries, as a test of their obedience, and generally exacts, under penalty of damnation, in case of failure.

The observance of religious duties is little interrupted in the Canaries by pursuits of commerce. Foreign ships seldom touch at any of them, except Teneriffe; the produce of which is chiefly exported from Santa Cruz. It consists, principally, in white wine, of which about twenty-five thousand pipes annually are made in the island. Part is sent to the Spanish settlements in South America; the English take off a considerable quantity. 
Teneriffe. in return for manufactures; and the North Americans, in payment of corn, staves, horses, and tobacco. The last article is contraband, and smuggled, chiefly, into Ticoronté, which, from the circumstance alone of its sandy beach, where the boats with prohibited goods can in the night approach and leave it without difficulty or delay, is lately increased in size, and become rich. Tobacco or snuff is in universal use; and that, which is legally imported, is sold by government at a profit so enormous, that the temptation to introduce it, clandestinely, is irresistible. The royal monopoly extends even to orchilla, a weed used in dying. It is a minute vegetable, of the lichen kind, growing chiefly upon rocks, of a loose texture, and produces a beautiful violet blue colour.

The total net revenue of the crown, after defraying the expences of administration, of all the Canary islands, amounts to about sixty thousand pounds a year. The monopolies, not the taxes, are considered to be the principal grievance of the inhabitants. The sugar cane was cultivated formerly among them more than it is at present. One sugar plantation in Teneriffe, which had been worked by a thousand slaves, is now very much reduced in labourers and produce.

Doctor Gillan, in his excursion through the island of Teneriffe, remarked, "that the appearances in it, for "volcanic formation and origin, are more numerous 
" and more striking than in Madeira. All the stones Teneriffe. " of the beach, all the ground and rocks in the neigh"bourhood of Santa Cruz are, manifestly, volcanic. "There was abundance of compact and cellular lava; " but none of a glassy nature, or pumice, except in the " neighbourhood of the Peak. He examined the stones " in the bed of the torrent, and at the bridge built across " it, between Santa Cruz and Laguna, as well as those "which constituted the pavement of the road up the " hill. The whole were of compact lava, of the same " kind and composition as those with which the Appian " way in Italy, and the streets lately discovered of Pom" peia, were paved, and such as are used for paving the "streets of Naples. The buildings of Santa Cruz and " of Laguna exhibited no stone of any other kind. On " enquiry it appeared that the lime, used for buildings, "was brought from some of the neighbouring islands; " no limestone being found in Teneriffe.

" Every circumstance, hitherto, argued in favour of " a volcanic formation, except the form of the moun" tains, whose irregular ridges, declivities, and ascents, " appeared very different from what mountains, pro" duced entirely by volcanoes, usually exhibit; in the " open plain, beyond Laguna, on the Orotava side, the "soil was not in the least volcanic, but composed of fine " mould, or what is commonly called virgin earth; a " mixture of clay, vegetable earth, and sand. There 
Teneriffe. " were several deep rivulets along the side of the road. "The beds, then, happened to be dry; and opportu" nities offered, in two places, of observing hollows, at " least, thirty feet deep: they exhibited no volcanic " appearance whatever. Immediately under the su" percial soil was a layer of deep loam; next, one of " tough clay; and all below, was an irregular mixture " of clay and sand. About two miles further on, the " hills were contiguous to the road. They consisted of "layers of indurated clay, and clay and iron ore, " similar to those discovered in Madeira: they bore no " marks of the action of fire.

"About three miles nearer to Orotava, at a village " situated on the summit of a hill, the volcanic appear" ances again began, and continued, without interrup"tion, to that town. The stones and shining sand, " upon the beach, are all volcanic; and from thence to "the Peak every rock and stone, that lay upon the " surface, and the surface itself, are the pure productions " of volcanoes. The glassy lava, the true pumice stone, "begins to be found only about the great basis of the "Peak. There is in the island no pure flint, or sand"stone. Its mountains are of two sorts; one, evidently, "volcanic; the other, primary, and composed of indu" rated clay, or of clay and calx of iron. In the low " plains there are layers of loose sand and soft argilla"ceous earth." 
Teneriffe is about seventy miles in length, and its Tenerife. mean breadth is about twenty-two miles; its surface amounts to one thousand five hundred and forty square miles, having, at an average, about sixty-five persons to the square mile. The number of acres is nine hundred and eighty-five thousand six hundred, which is, upon an average, about ten acres to every individual in it, the number of inhabitants being calculated to be nearly one hundred thousand; of whom, however, there is, annually, a drain to the Spanish colonies in South America, to increase the number of foreign settlers there, for the purpose of counterbalancing the multitudes, still remaining, of the natives, and for supporting the dominion of the Spaniards over them. The poor of Teneriffe are persuaded easily to migrate, as the proprietors of the land do not give them sufficient employment throughout the year; and they have not the resource of manufactures, except a trifling one in silk, chiefty, stockings. The price of labour is under a shitling a day; and, beside corn and roots, the principal food of the common people is confined to cod-fish, caught on the neighbouring coast of Africa, or imported from North America.

Yet the people are not much subject to disease; and instances of longevity, even to an hundred years, are said not to be rare amongst them. The air is dry and pure. The variations of the thermometer seldom exceed vor. I. 
Tenerifie. fourteen degrees, from sixty-eight to eighty-two, in the inhabited part of the island. It remained at seventy-two while the Lion continued at Santa Cruz.

The race of the Guanches, or aborigines of Teneriffe, is now almost extinct. They have not been, like the natives of South America, much diminished, by cruel treatment from their conquerors; but a society of people, less refined, always dwindles in the neighbourliood of one which is more so. The former, cramped in their possessions and excursions, daily repining at their dependence, and putting no limits to their indulgence in spirituous liquors, which the deleterious arts of their neighbours furnish at an easy rate, become gradually encrvated in body and mind; and their race disappears, at length, from the surface of the earth. The very few Guanches, who remain, are entitled to some very trifling stipend, as a price of the submission of their ancestors, from the court of Spain, which they punctually, and with some sensations of pride, annually demand. Many of the dead bodies of those Guanclies have been found in perfect preservation, in an erect posture, placed against the sides of caves dug into the mountains, the bodies wrapped round with several folds of goats' skins.

The native Canary bird is of a greyish colour, with some ycllow feathers on his breast, which increase in size and number as the bird grows older. But the Canary birds, usually sold in England, arc mostly bred in 
Germany, and, by domestication, are much altered from Teneriffe.

the wild natives of the Canaries; and their notes are less pleasing.

Teneriffe, tho not the largest, is probably the most fertile of the Canary islands, as far as can be inferred from the inferior population of the others. The population of the Grand Ganary island, according to the best accounts, amounts to no more than forty thousand inhabitants; that of Palma to thirty thousand; Forteventura ten thousand; Lancerota eight thousand; Gomera seven thousand; and Hierro, or Ferro, fifteen hundred. This last island is the most to the westward of the Canaries, and, indeed, the most western part of the old world; and was once, among geographers and navigators, a spot of considerable importance; as, by general consent, it was considered as the first meridian, from which the degrees of longitude were reckoned, as those of latitude are from the Equator. But observatories having been since erected in England and France, the astronomers of those countrics have preferred to calculate the longitude as beginning at the respective places where they made their observations; and, now, it is generally reckoned from Greenwich or from Paris.

On the twenty-seventh of October the Lion and Hindostan continued their route from Santa Cruz towards Port Praya in the island of St. Jago. They met, immediately, with the trade winds which are already mentioned 
Passage to to blow over the ocean, constantly, from the eastward.

The ships were thus, quickly, wafted beyond that portion of the globe, which was considered as dividing the temperate from the torrid, and uninhabitable, zone. And the latter certainly would merit that appellation, were it not for those regular breezes which moderate the heat.

"In this passage currents, also, as in the former, "were observed by Sir Erasmus Gower; but their di"rection was various. The weather was hazy, and the "wind steady, impelling the ships at the rate of fifty " Jeagucs, or one hundred and fifty nautical miles a " day. In the morning of the first of November, the " isle of Bonavista, one of the Cape de Verde's, came in " sight. About this time the weather became extremely "sultry; and there was an unhealthy humidity in " the air, which threw the body into a state of lan"guor. The thermometer kept between eighty-two " and cighty-four degrees. They left Bonavista to "the north-west, about the distance of eight or nine "leagnes. On the north-east end of that island was a " hill, which, from its conical and truncated shape, had "the appearance of having been a volcano. There was " another, much higher, near the soutl-west end, with "high land to the westward of it. The sea coast, on "the south-east side, was guarded by rocks; but to"wards the sonth-east end the shore was much covered 
" with white sand. There did not secm to be any cul"tivation or inhabitants on that side. The latitude of

"Bonavista was sixteen degrees six minutes north, and "the longitude twenty-two degrees forty-seven mi" nutes west from Grcenwich. Variation twelve de"grees thirty-six mimutes to the westward of the pole. "The afternoon of the second of November brought "the isle of May in sight. The north-east end of it " was extremely low, little above the level of the sea, "with a covering of white sand, not always easily dis" coverable in the night. The land rises, gradually, " till it arrives at a volcanic mountain; to the south" west of which was irregular ground; and soon fol" lowed a high disorderly peak, much more lofty than "the volcanic cone. The island was left to the north"west about ten miles. Its latitude was fifteen degrees "ten minutes north; its longitude twenty-three degrees " five minutes west of Greenwich. The variation of "the compass was here twelve degrees west. "At six o'clock of the following morning the island "of St.Jago appeared; and, at noon, the Lion anchored " in Praya bay, in seven fathoms water, the church " bearing north-north-west half west, and the north-east "end of a small island, in the bay, north-east. The " bottom there is better than at a depth of twelve or "fourteen fathoms, beyond which it is uncertain and "rough. The bay is open to the wind from south-east 
St. Jago. "to west by south; but it is never supposed to blow " here so hard, or to bring in so much sea, as to en" danger a ship's continuing to ride at her anchors "steadily. The latitude of the bay is fourteen degrees "fifty-six minutes north, and the longitude twenty"three degrees twenty-nine minutes west. The va"riation of the compass is twelve degrees forty-eight "minutes west. The tides, in the full and change of "the moon, rise nearly five feet perpendicular. English " men of war salute with eleven guns, on an assurance " of a return of an equal number.

"This bay had, for several years, been frequented "by ships bound to the southward, as bullocks, sheep, "hogs, goats, poultry, and fruits were abundant and "reasonable. Fish was, likewise, taken by the seine, " which is a large net, cast into the sea, and hauled af" terwards ashore, supplying enough, at once, for whole " ships' companies. An excellent kind of rock-cod " was, likewise, caught from the rocks with rod and "line."

The island bore, now, from the ships' decks a brown appearance; but the verdure of the large waving leaves of the cocoa-nut, and date, trees, growing in the sand behind the beach, still gave scme cheerfulness to the prospect; as soon, however, as the ships' boats had linded, a ghastly figure, walking hastily along the shore, announced the desolate situation of the island. 
It was an English sailor, who had served on board a st. Jago. Dutch East Indiaman, but had been left, by some accident, behind at St.Jago. The island, he said, was in an absolute state of famine. Little or no rain had fallen there for about three years before. The rivers were, almost all, entirely dry. The surface of the earth was, in general, naked of any herbage. The greatest part of the cattle had already perished, not less through drought, than want of food. Of the inhabitants many had migrated; many were famished to death. The narrator was himself a striking specimen of the misery he described. Tho he had not been long upon the island, he had already severely suffered by the general want. He had no occupation on shore. He had no money. Of the scanty stock of a common seaman's clothes, the chief articles had quickly been exchanged for roots or any thing eatable, to support life. English ships that had called at Praya bay, since his arrival, refused to take him on board, on account of his having gone into foreign service. By a humane regulation of the British navy, every British sailor left in foreign ports by British ships, whether warlike or mercantile, is received on board any of his Majesty's ships which touch there. This poor man was in a predicament which deprived him of that resource. He found himself on that element, on which nature had, indeed, intended him to continue, but which denied him, now, its comforts; 
st. Jago. and he seemed to cast his longing eyes, in vain, towards that other, to which he had dedicated his life.

At the end of the sandy beach, turning to the right of St. Jago, close to the rock, and at the foot of an elevated plain, were the remains of a once neat and elegant chapel of the Romish church, erected, probably, in that spot, by the grateful piety of some person saved from shipwreck. The decay of such a building, in a settlement of Portugueze, resembling the monuments of a religion now no more, was, in itself, no slight symptom of the general devastation.

On the elevated plain, just mentioned, was the hamlet, rather than the town, of Praya, the residence of the governor-general, for the crown of Portugal, of the Cape de Verde on the main land of Africa, and of the Cape de Verde islands opposite to it. This hamlet consisted of about one hundred very small dwellings, one story high, scattered on each side of the plain, which extended near a mile in length, and about the third of a mile in breadth; and fell off, all round, to the neighbouring valleys and to the sea. Not bcing commanded by any neighbouring eminence, it was a situation capable of defence; the fort, however, or battery, was almost in ruins; and the ferv guns mounted on it were mostly honey-combed, and placed on carriages which scarcely held together. It was understood at St.Jago, that the militia there consisted of three regriments, of 
of about seven hundred men each, chiefly officered by st. jago. Mulattoes and Negroes; not above ten white officers in the whole: one of them was the inn-keeper. The best building was the jail; and the next, the church, at which officiated a priest, who was a dark-coloured Mulatto, or the mixed offspring of a black parent and a white one.

The Governor dwelt in a little wooden barrack, pleasantly situated at one extremity of the plain, looking down a valley over a grove of cocoa-nut trees, and having a view of the bay and shipping. He received the Embassador with all due honours, on his landing, advancing a considerable way from his house, to meet and conduct his Excellency to it. On such occasions, it was usual to offer wine and other refreshments; but none appeared on the Governor's table, for a reason not to be controverted. He partook of the general wretchedness, arising from the dreadful drought, which had so long prevailed, and rendered the country, nearly, as barren as a rock. Yet the island appeared covered with a layer of vegetable soil. The general surface was sufficiently level to retain any moisture that fell upon it; and from its centre rose mountains, of a height which promised to stop, and condense, from the passing clouds, any water they might hold in vapour. No change had been observed in the steady current of the winds, blowing from the east, which are common to tropical climates. Yet the frequent showers, which were observed by the VOL. I. 
st. Jago. first navigators who touched there, induced them to give the island the name of Pluvialis.

What were the uncommon circumstances that took place in the atmosphere of that part of Africa, to which the Cape de Verde islands lay contiguous, or, in the vast expanse of continent, extending to the east behind it, and from which this direful effect must have proceeded, as they happened where no man of science existed, to observe or to record them, will therefore remain unknown; nor is theory bold enough to supply the place of observation. Whatever was the cause, which thus arrested the bountiful hand of nature, by drawing away the sources of fertility, it was observable, that some few trees and plants persevered to flourish with a luxuriance indicating that they still could extract from the arid earth whatever portion of humidity it was necessary to derive from thence for the purpose of vegetable life, tho it was denied to others.

Beside the trees of the palm kind, already mentioned to be verdant amidst the burning sands, nothing, for example, could be more rich in flower, or abound more with milky, tho corrosive, juice, than the asclepias gigantea, growing plentifully about, several feet high, without culture, indeed, but undisturbed, it being of no avail to cut it down in favour of plants that would be useful, but required the aid of more moisture from the atmosphere. The jatropha curcas, or physic nut 
tree, which the French West Indians, with some proSt. Jago. priety, call bois immortel, and plant. on that account, in the boundaries of their estates, appeared as if its perpetuity was not to be affected by any drought. Some indigo plants were still cultivated with success, in shaded vales, together with a few cotton shrubs. Throughout the country some of those species of the mimosa, or sensitive plant, which grow into the size of trees, were most common, and did not appear to languish. In particular spots the annona, or sugar apple tree, was in perfect verdure. The borassus, or great fan palm, lifted, in a few places, its lofty head and spreading leaves with undiminished beauty. In a bottom, about a mile and a half behind the town of Praya, was still growing, in a healthy state, what may be called, for size, a phenomenon in vegetation, a tree known to botanists by the name of adansonia, and in English called monkey bread tree. The natives of St. Jago call it kabisera; others, baobab. Its trunk measured, at the base, no less than fifty-six feet in girth; but it soon divided into two great branches, one rising perpendicularly, and measuring forty-two feet in circumference. That of the other was about twenty-six. By it stood another, of the same species, whose single trunk, of thirtyeight feet girth, attracted little notice, from the vicinity of its huge companion. See the engraving at the end of this chapter. 
St. Jago. But the annual produce of agriculture was scarcely to be found. The plains and fields, formerly productive of corn, sugar-canes, or plantains, nourished by regular falls of rain, now bore little semblance of vegetation. Yet in the small number of plants, which survived the drought, were some which, from the specimens sent to Europe, were found to have been hitherto unknown. Vegetation quickly, indeed, revived wherever, through the soil, any moisture could be conveyed.

The governor's secretary invited some of the gentlemen from the Lion to his garden, distant about two miles, inland. They were very agreeably surprised with a view of a small clear rivulet (issuing from a source at the bottom of some rocks) shaded by, as well as nourishing, a fine fig tree, not that of Europe with rough and deep indented leaves, but another species, with entire long leaves, and of which the fruit, then plucked off the branches by hands stretching over the fountain, was perfectly delicious. Wherever the rivulet was made to rum, every species of vegetable near it flourished. Here, among others, was planted the maniota or cassada tree, of which the juice, expressed from the root, is a deadly poison, while the root itself is salutary food, as is also the sediment, deposited from the poisonous juice, being the substance sold in England under the name of tapioca. The rivulet soon, however, fell into a bottom, from whence the adjoining grounds 
were no longer irrigated; but it supplied many of the principal inhabitants of Praya, who sent tihat distance St. Jago. to get good water. The cattle, near it, were relieved from thirst, and the fields adjoining were like a bleach ground, from the quantity of linen, washed in the little stream and dried close to it. In the secretary's garden was a lofty cocoa-nut tree, filled with fruit, growing round the upper extremity of its single trunk, near the origin of its great spreading leaves. The trunk, in rising, declines somewhat from the perpendicular, and has joints, at short distances, like the sugar cane. To get at the fruit, a man ties a rope about his ankles, so as to leave a space of about a foot between them. The man, generally a Negro, thus prepared, with his arms embraces the tree, while he rests upon the joints, not with his feet, but by the rope connecting them. His body thus supported, he lifts his arms higher; and thus, successively, raising his hands and feet, quickly arrives at the spot from whence he can reach, and throw down, the fruit to the spectators below. The shell is lined with a white and almost solid substance, pleasing to the taste, but difficult to be digested in the stomach. Within this substance is contained a thin subacid liquor, peculiarly grateful in hot climates. The shell serves, in ordinary use, for a drinking vessel; and is of so compact a substance, as to imbibe little of any fluid poured into it. Outside the shell are strong fibres, frequently twisted 
St. Jago. into ropes, which are chiefly used in lieu of those of hemp, in the countries which produce this tree.

The secretary, who was a Portugueze subject, and a native of Brazil, had some taste for science, and had attached himself to botany, which may be thought a proof, or instance, of that branch of knowledge extending where others are little cultivated. The general calamity of the island was attended with aggravated disappointment to the botanist, whose researches were, necessarily, stopped by the little variety of objects to examine.

Some of the party, who had visited the secretary's garden, made, afterwards, a longer excursion, crossing the country, to the town and former capital of the island, and which is also called St.Jago. The soil, as far as they went, had all the appearance of natural fertility, and bore the marks of extensive tillage, but looked as if it had been ravaged by fire, or by an enemy laying all things waste. They saw some cattle, lank, indeed, and scarcely capable of moving; but the cause of astonishment was, that they should still remain in existence, with the little food they could draw from the scorched surface of the earth. The party traversed one small river, not quite dried up, but shallow, and losing itself among the pebbles of the broad bed over which, formerly, it rolled. An overlianging mountain appeared as if it had been cleft in twain; and one half 
had been swept away by the violence of some torrent. St. Jago, On arriving at the boundary of an elevated plain, they entered a fort, in ruins, originally meant to defend the steep descent towards the town of St. Jago, which is situated in the bottom of a vale, formed between the plain just mentioned, and a high hill opposite to it: this vale seemed to have been scooped out by the force of a violent torrent, rolling along with it great rocks, which stood in its passage, and emptying itself with them into the sea. Thus a small, irregular, and unsafe harbour was formed by those rocks, while the current itself is diminished into a stream so small and sluggish, that it cannot clear its mouth from the sands which the tide throws in, and by which it is almost choked up. On each side of this little stream are the remains of dwellings of considerable solidity and size; and the fragments of glass lustres, still hanging from the ceilings of some of the principal apartments, denote the elegance or riches that were once displayed in this, now deserted, place. Not above half a dozen families remain in it at present ; the rest abandoned it, or perished.

Here was still, however, an attempt at a slight manufactory of striped cotton slips, the same as are made in the other parts of the island, for the use of the Africans on the main, who pay for them in slaves, elephants' teeth, and that gum which is generally called arabic.

Amidst the ruins of St. Jago the party found a Por- 
st. Jago. tugueze, to whom one of them was recommended, and who received them with the most cordial hospitality in his house, and treated them with every species of tropical fruits from his garden, lying on each side the river. He had been a navigator, and informed them that the isle of Brava, one of the Cape de Verde's, was a fitter and safer place for ships to call at, for water and provisions, than the island of $\mathrm{S}$. Jago; that it had three harbours, one called Puerto Furno, on the east side of the island, from which vessels must warp, or be towed out by boats; the Puerto Fajendago to the west, and the Puerto Ferreo to the south, which was the best for large ships, and into which runs a small river. In another of the Cape de Verde islands, called San Vicenté, he observed that there was also a large harbour on the north end, but that fresh water was at some distance from it: and there was, likewise, a good port at Bonavista.

This information of the harbours in the isle of Brava was confirmed by accounts given by others to Sir Erasmus Gower, who recommends to make a trial of them.

But all the islands of Cape de Verde were said to have experienced the same long drought, and to be, consequently, in a similar state of desolation. Tho they are about twenty in number, including the smallest and most insignificant; their present reduced population 
little exceeds forty-two thousand inhabitants; of whom St. Jago. about twelve thousand are said to be in the island of St. Jago; eight thousand in Bonavista; seven thousand in the isle of May; six thousand in that of San Nicolas the residence of the bishop of the Cape de Verde's, and the pleasantest of them all ; four thousand in San Antonio; as many in San Phelippe de Fuogo, remarkable for a volcanic fire constantly issuing from the cone of a mountain in its middle; not many more than five hundred in the isle of Brava; and still fewer in the remaining isles, not specified.

Of the island of St. Jago " the south-west side only," Doctor Gillan observed, "had any appearance of vol"canic formation. About two miles from Praya bay " is a very high hill, altogether composed of clay and "sand, on which not the least marks appear of the "action of fire. About six miles, near the road, from " the town of Praya to that of St. Jago, is another hill, " almost entirely composed of rich iron stone, of a deep "blue or purple colour, formed of clay, calx of iron, " and siliceous earth. In the rocks opposite the gover" nor's house, near Praya, are several narrow perpendi" cular veins of white spar. The beach is covered with " a fine siliceous sand."

Into Praya bay, while the Lion and Hindostan Iay there, came several trading vessels from Dunkirk; one of them attracted notice, as being that which was forVOL. I. 
st. jago. merly called the Resolution, so celebrated under the command of Captain Cook. These ships were soon joined by others, coming from Nantucket, in America: their masters announced that they were all bound for the coast of Brazil and the Faulkland islands, to carry on the whale fishery there. The Dunkirk vessels were manned, chiefly, by English sailors, were full of English goods, and were supposed to belong to adventurers in London, and to be really intended to try a trade, under French colours, with the Spanish coasts of Chilili and Peru.

Praya bay was rendered somewhat interesting, too, by having been, not long before, the scene of action between the English and French squadrons, under the respective commands of Commodore Johnstone and Admiral de Suffien. The latter, in attacking the British ships of war and Indiamen in a neutral port, committed a gross violation of the rights of nations. Some time afterwards, while commanding the French fleet in the East Indies, he complained to one of the present passengers in the Lion, who went in a flag of truce on public affairs to the French head quarters, of the conduct of the British admiral authorizing a small French vessel to be taken ont, by force, from the nentral port of Tranquebar, belonging to the Danes, on the coast of Coromandel; and being reminded of the example he had sct at Pray, he replied, that "the object, in the former 
" instance, was too trifling to make it worth the infrac" tion of a public law." Such are the maxims of political morality.

The Portugueze maintain no force, at St. Jago, capable of insuring a proper respect to their flag there; and so far are they from drawing any revenue from the place, that supplies are sent to it from Portugal. None of these islands are, indeed, encouraged by the regulations of the parent state. A trade for slaves from Africa is established at St. Jago; and that trade is a monopoly to the crown. The governor derives his chief profit from the sales of cattle to the ships who call there; and of the amount of those sales he claims a moiety. Such is the state of the inhabitants, without any regular communication with other countries, that their sole dependence for a supply of whatever their own island cannot afford, is upon vessels stopping, casually, there. They set little value upon money, which might lie long useless in their hands; preferring to barter whatever they have to sell, for a return, principally, of corn or clothing, rather than any quantity of specie that would be offered to them.

The very scanty provisions they had to dispose of, to the Lion and Hindostan, could be no inducement to delay. The water, too, was neither good, nor easy to be had: it was drawn from wells, and that which afforded 
St. Jago. the most tolerable, was about five hundred yards distant from the beach. Sir Erasmus Gower advises " to draw " it very early in the morning, as it is afterwards soon " disturbed by the neighbouring inhabitants, who take " much of it away. It is not less necessary, for the "preservation of the seamen, to avoid employing them " in the middle of the day, as the weather is extremely "sultry, the thermometer seldom under eighty-five de"grees, and often above ninety. It had, formerly, oc" curred, to prefer the coolness of the night, to roll the "casks of water to the beach, and to float them off to "the boats, lying at anchor at some little distance on " account of the violence of the surge; but the experi" ment has been fatal, whole boats' crews dying in con"sequence of it." Mr.Jackson, master of the Lion, had an idea of sinking casks in the beach, near the sea, almost up to the brim, with holes in their bottoms and sides, by which means the casks would soon fill, he thought, with good water, filtered through the sand. And such an experiment may be, certainly, worth making, where good water is not, otherwise, to be had, or is too far distant. But the Lion and Hindostan were not driven to the necessity of this trial, having a sufficient reserve of water to the place where they next proposed to stop, for such refreshments as St.Jago could not afford. They had been, already, five days 
in Praya bay, and the Jackall tender did not appear. St. Jago.

It was, therefore, now determined to prosecute the voyage without her; and on the eighth of November the ships set sail from the island of St. Jago.

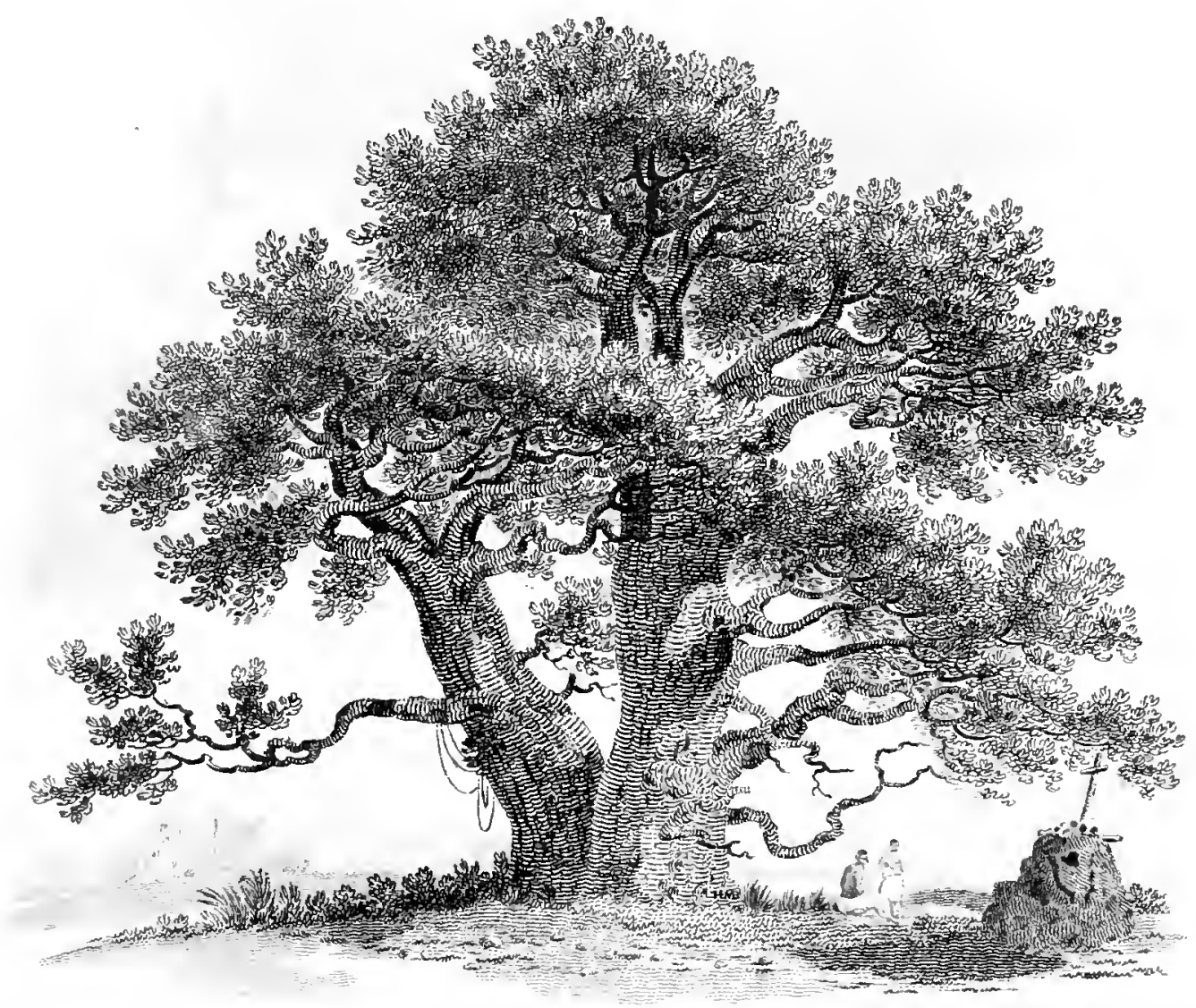




\section{CHAPTER V.}

PASSAGE OF THE LINE. COURSE ACROSS THE ATLANTIC. IIARBOUR, GITY, AND COUNTRY OF RIO DE JANEIRO.

No part of the African continent, from the neighbourhood of which the Lion and Hindostan were now directing their route, extends so much to the westward as that which lies near the imaginary line called the Equator, or almost equidistant from the two poles; nor, on the other hand, does the land of South America any where advance, or swell, as it were, so much out to meet the ancient continent to the eastward, as within a few degrees of the same line. Thus the waters of the Atlantic are, hereabouts, brought with in narrower bounds than either to the northward or to the southward; and as, over what thus may comparatively be called a strait, the windsblow almost perpetually from the eastward, it is not improbable that vessels may, at different times, have been driven from the old to the new continent.

Across this tract of ocean it is usually observed that the winds, blowing easterly from the continent of Africa, alter their direction as they approach very near the opposite contincent of America; and take a course between the north and west. Such winds are too favour- 
able not, occasionally, to be sought for by vessels in their

way to, or round, the Cape of Good Hope, which lies to the south-east. The settlements on the coast of South America afford also those refreshments in abundance, which ships sometimes fail of finding in other places; as was the case with the Lion and Hindostan at St. Jago.

The friendly port of Rio de Janeiro promised every advantage; and these ships bent their course that way on leaving the Cape de Verde's. The weather continued for some time hazy and very sultry. Many of the seamen, who suffered in Praya bay, were still indisposed on board. There was neither much rain, nor lightning to clear the atmosphere. Under these circumstances mortality often rages; and ships of war, thronged with men, frequently lose no inconsiderable proportion of their complement. The humid heat between decks, where seamen are often crowded, and the impurities, sometimes suffered by their carelessness to be accumulated, tend not a little to their destruction. But Sir Erasmus Gower established such methods and regulations for insuring cleanliness, and a constant circulation of fresh air, throughout the ship, as, with other precautions, contributed materially to preserve his people. Every part of the Lion was washed carefully with vinegar; and sulphur was burnt whenever it was practicable. Ventilators of different constructions, worked 
Passage of by hand, and applicable to the different parts of the the Line. ship, were placed wherever they could be put in use. The men's hammocks, with their bedding, were brought upon deck at a fixed hour every morning, and left in the open air till the approach of night, except when showers of rain made it necessary to put them under cover. Columns of fresh air were conveyed through every part of the ship, and close even to the keel, by the means of wind-sails, or cylindrical tubes of canvas, of about two feet diameter, open at both ends, and extending through the hatchways, from above the upper to below the lowest deck. Near the upper extremity of this canvas tube is a slit or opening in its side, which is always turned towards the quarter from whence the wind, at that time, blows. Attention was paid, likewise, to the people's diet, by mixing with their animal food as great a proportion of vegetable matter as could be provided. No spirituous liquors were distributed or allowed, without a due admixture of water with them. The water itself, which is apt to acquire a putrid taste and smell in the hogsheads that contain it, was prepared for use by being put in jars open to the air, and by being passed repeatedly through a tin cylinder, pierced with holes; which is found to frce it, in grcat measure, from its noxious and disagreeable qualities.

The steadiness of the trade wind, not only regular in its direction, but generally likewise in its strength, left 
little to occupy the hands, or attention, of the seamen, as to the manœuvres of navigation. But they were kept in moderate and healthful exercise by other means: some in working the several ventilators, some in cleaning out every apartment and division of the ship; the carpenters and armourers, with several assistants, were employed in making or repairing whatever was deficient in their departments; some splicing cordage, and converting what could not any longer be used as such, into oakum; many more in sewing new sails, or piecing those that happened to be torn; and some, likervise, in mending their own apparel: combining, thus, the economy of individuals with that of the public service: and, on these occasions, the ships' decks exhibited the appearance, in some sort, of a dockyard, sail-loft, or other busy manufactory.

By such means as these the men gradually recovered; and were prepared to enjoy the festivities usual on the passage of the Line. No doubt, the entrance into another hemisphere, when it first was made, must have been an event arresting the attention, and filling the minds of those, in every station, who were witnesses of it. And the commander who, for the first time, had the good fortune to cross the Line, probably indulged his crew in testifying a joy he must have sincerely felt himself. The lower orders of mankind, who know little of life except its labours, are not easily forgetful of any occa- 
Passage of sion, recurring to them so seldom, of enjoying a mo-
the Line. the Line. mentary gleam of happiness and independence. It reconciles them to subsequent subordination, and, even, suffering. They seldom abuse the indulgence thus allowed them; and frequently tire, in a little time, of what they entered upon with so much eagerness, and conceived to be productive of so much pleasure; and, feeling that idleness ceases soon to be enjoyment, return with resignation, and real comfort to their wonted occupations. The amusements, on this occasion, consisted chiefly in dressing up a sailor, of a good figure and manly countenance, in the supposed proper habit of the sea god, Neptune, armed with a trident, and his garments dripping with the element submitted to his power. He stood at the ship's head, as if he were rising out of the ocean, and demanded, with an audible voice, what was the ship thus encroaching upon his dominions? An answer being given from the quarter-deck, where the Embassador, Sir Erasmus Gower, the officers and passengers, all stood, announcing the ship's name, and purport of the voyage, Neptune, with his attendants properly accoutred, stepped with great solemnity towards them, and, with some words of compliment to his Excellency, presented him a fish (litely caught) as part of the produce of the deity's domains. His godhead was treated by all with great respect; and becoming offerings of silver were voluntarily made to him, for 
himself and his companions, by those who had crossed the Line before; but were exacted as a just tribute from those who attempted it for the first time, under penalty of going through ceremonies, not a little ludicrous, and promotive of much broad laughter among the initiated in those mysteries. They concluded with a plentiful repast, accompanied with the music of the bagpipe, and copious, tho not excessive, libations of exhilarating liquor.

In the neighbourhood of the Line, a stagnated atmosphere often suffers the equinoctial heat to act in full force upon the human frame; but, in the present voyage, there was very little calm. The south-eastern breeze was steady, and the weather pleasant: yet the horizon appeared nearer to the eye; and the arch of the sky seemed to form but a small segment of a circle. The clouds descended to the proximity of the ocean; and, in several places within sight at once, they seemed to dip down towards it, and attract a part of its contents in the form of water-spouts, the drops rising, apparently, and meeting the bending cloud. All the vessels that were observed traversing this part of the ocean, were traders between Portugal and its African settlements, on the one hand, and its opulent colonies in the Brazils, on the other; as if, here, both sides of the Atlantic, exclusively, belonged to that crown. Few birds were seen throughout this passage; and few fish were caught. The sailors enjoyed, how-

voL. I. 
ever, the pleasure of destroying an enemy, in harpooning a shark, several feet long, whose wide gaping jaws and numerous rows of teeth denoted the voraciousness of its nature. On dissection, its breast was found to contain no lungs, and as if destined only to be a pericardium, or bony inclosure for the heart; the five spiracles, or openings behind its head, communicating simply with the gills situated near the jaw. One beautiful dolphin, which was hauled on board, afforded an opportunity of observing how wonderfully this fish varies its colours, from yellow to blue and purple, in the agonies of death.

" The temperature," as Sir Erasmus Gower observed, " of the climate improved, feelingly, as the ships re" ceded from the coast of Africa; yet the thermometer "kept at eighty or eighty-one degrees. The sea was "smooth; the currents frequent, setting as often to the "southward as to the northward. The north-east wind " began to abate about the ninth degree north from the "Equator: then the wind became more easterly, and " sometimes drew to the southward of east. The Equa" tor was crossed in the twenty-fifth degree of western " longitude from Greenwich; with a fresh breeze from "the south-east. Ships, in crossing the Equator, must " be determined by the winds which the season of the "year produces. When the sun is far to the southward " of the Line, the south-east winds begin in seven de"grees of latitude north, which force vessels, some- 
"times, as far as the twenty-seventh degree, or more, of " western longilude, before passing the Equator. When

" the sun is to the northward, the Line may be crossed

" in a longitude much more eastern, the winds then

" blowing generally from the north-east. In the pre-

" sent instance, it continued to blow from the south-east

"quarter, not varying more than to the east-south-east,

" till the ships arrived at the seventeenth degree of lat"titude south of the Equator, when the wind, being " influenced by the land of the Brazils, came first to "the north-east, and then changed, gradually, to the " north-north-west, until the land appeared in latitude "twenty-two degrees forty minutes south. Previous to " that period, pains were taken to find out the Abrolhos " shoal, as laid down from the authority of Lord Anson " and several captains of Indiamen; but no bottom was " found, on sounding twice with a line of two hundred " fathoms, first, in latitude sixteen degrees eighteen mi" nutes south, and in longitude thirty-six degrees five "minutes west, and the second time, in eighteen de" grees thirty minutes south, and thirty-six degrees " fifty minutes west longitude. In latitude twenty-two " degrees south, and longitude forty degrees thirty-four " minutes west, the colour of the water was perceived "to indicate soundings, which, on trial, were found at " the depth of thirty-three fathoms. The weather was " not then clear; but soon afterwards, on the twenty- 
Course " ninth of November, the land of the Brazils was seen across the " at the distance of ten leagues. Thus was the voyage " performed, from England to South America, in one " day less than two months. If, from this time, nine" teen days, during which the ships were at anchor at " Madeira, Teneriffe, and St. Jago, be deducted, it will " be found, that each day's sailing must, upon an ave" rage, have exceeded one hundred and fifty miles, and " that the whole passage was as quick as had been re" membered. The land, which had been seen, lay to " the north ward of the island called $F_{1}$ io, and was very " high and irregular, having remarkable peaks, with "white vertical streaks, resembling, at a distance, cas"cades of water, or veins of mable. Steering southerly "towards Frio, a small island is perceived, of a mode" rate height, detached from the main land about three "miles; and there appears a clear passage between it " and the land. The island of Frio lies about south" west, eight leagues from the former. The shore be"tween them seems perfectly free from danger. The " land of Frio is high, with a hollow in the middle, " which gives it, at a distance, the resemblance of two "separate islands. The passage between Frio and the " continent is about a mile broad, and seems clear from " shoals. The latitude is thirty-two degrees two mi" nutes south; longitude, by observations, forty-one "degrees thirty-one minutes forty-five seconds west. 
"In sailing westward towards Rio de Janeiro, the shore " is perceived to be covered with white sand; the land " irregular and high, with two or three small islands Atlantic. "near it."

Captain Mackintosh, from experience, recommends to ships, bound for the harbour of Rio de Janeiro, " after getting in with Cape Frio, instead of steering "along shore, to shape their course between south" west and south-west by west, for twelve or fourteen "leagues. To this distance the land wind extends. "The forenoons, in general, are calm, but almost every "afternoon a fresh sea breeze sets in from the south" west. It is proper to steer, in a direct course, from "lence to the small islands lying under the great in" clining Sugar-loaf on the western side of the entrance " into Rio harbour. From these small islands the wind "will carry the s!ip to the opposite side of the har"bour's mouth, where the fort of Santa Gruz is situated, " and which may be approached within fifty yards, " and from thence, safely and quickly, into harbour." Captain Mackintonh adds, "that in his first voyage to " this place, by keeping in shore, he spent five days of "very unpleasant and troublesome navigation before " he could get into the harbour; whereas, by the me"thod now laid down, he came the same distance in " much less than twenty-four hours, and with great " ease and satisfaction." 
Course Sir Erasmus Gower observes, that "the entrance of across the Atlantic.

"the harbour will shew itself by discovering the castle " or fort of Santa Cruz, and a small fortified island, " called Fort Lucia, nearly abreast of it. Between these " is the channel into the harbour, near a mile wide; " both shores are steep; that of Santa Cruz is perpen" dicular, there being six fathoms in the wash of the "sea. The narrowness of the channel causes strong "tides; but as the sea breeze blows fresh, they do not " impede entering into the harbour. In going in, it is " best to keep mid channel, or even nearer to Santa "Cruz. About four miles outside the harbour's mouth, " the depth of water is eighteen and nineteen fathoms, " which will decrease, gradually, to eight or seven; " and this, being the shallowest part, may be called the " bar, which is about two miles outside the fort. The " water again deepens, on approaching to Santa Cruz, " to seventeen and eighteen fathoms; nor will less be "found in the fair way of the great road. Large ships " may moor in shoaler water; but that depth, or there" abouts, is more advisable, as such a situation affords " the full advantage of the sea breeze, as well as that "of ayoiding the insects, which are very troublesome "when nearer to the shore. The Lion anchored in " eighteen fathoms, the Sugar-loaf bearing south by east " hall east; the castle of Santa Cruz south-east by south; "a convent on an eminence over the south part of the 
" city south-west by west; one mile and a half from the

" landing-place opposite the viceroy's palace.

"Before a ship attempts to enter into the harbour, it " will be proper to send a boat, with an officer, to the " castle of Santa Cruz, who will be conducted, from " thence, to the palace of the viceroy, to give him in"formation of the ship's arrival, and the occasion of "her calling. The ship's colours should, also, be " hoisted early, unless the pratique, or usual visiting "boat from shore, be already on board; a vessel, " even of the Portugueze nation, attempting to pass " the fort, will be hailed, and peremptorily desired to " anchor, until permission be granted for proceeding. " Every particular of the ship, her condition, force, " destination, and wants, are required to be declared, " under the signature of the captain; after which every " indulgence and assistance are readily promised to be "given; but the ship's people are not suffered to land. " at any place, except at the stairs opposite the palace; " and a military officer or soldier, generally, attends " every person from on board while he remains on " shore. Guard-boats, also, surround the ship, to pre"vent landing, except when and where permitted. "And those regulations are still more rigidly enforced " with regard to mercantile vessels than to ships of war. "In the inner harbour, formed by an island called Ilheo "dos Cobras, or serpent island, are proper wharfs for 
Rio de " heaving ships down by; but the mode of doing it
Janeiro. " alongside hulks is now preferred. In the same har" bour all ships anchor which are loading or un"loading goods, or want repairing; but the outer is "the more healthy situation. The latitude of $\mathrm{Rio}$ is " twenty-two degrees fifty-four minutes south, and lon"gitude forty-two degrees forty-four minutes west from "Greenwich. Variation of the compass four degrees "fifty-five minutes to the westward of the pole. The " tide flows seven hours and a half, and rises about five "feet and a half perpendicular. Fahrenheit's thermo" meter, during the Lion's stay, was between seventy" seven and eighty-two degrees."

Rio de Janeiro is scarcely to be excelled for the capaciousness and security of its harbour, or its convenience for commerce, and the richness and fertility of the circumjacent country. The entrance into it, from the sea, is bounded, on one side, by the leaning cone already mentioned, measuring seven hundred feet in height, and by the huge mass of granite, supporting the castle of Santa Cruz, upon the other; and is interrupted, near the middle, by the little island on which Fort Lucia is erected. On entering into the harbour, it was found to enlarge to a width of three or four miles, and to penetrate in several branches, farther than the eye could reach. It is interspersed with many islands, some entirely green, and some covered with batteries or 
habitations. The shores of the harbour were diversified and embellished with villages, farms, and plantations, separated by rivulets, ridges of the rocks, indentures of little sandy bays, or the skirtings of a forest; the whole terminated, in distant prospect, by an amphitheatre, or screen of mountains, rising in a vast variety of rude and fantastic forms, but covered with trees to their very summits.

Within four miles of the harbour's mouth is situated, on the west, the city of St. Sebastian, usually called Rio, built on a projecting tongue of land; but all the ground behind it is broken into hills and rocks, with woods, houses, convents, and churches on their tops. A convent of Benedictines, and, also, a fort commanding the town, are situated upon the extreme point jetting into the harbour; opposite to this point is the Ilheo dos Cobras, or serpent island, between which and the town is a narrow channel, sufficiently deep, however, for the passage of the largest ships. Upon the island are a dockyard, magazines, and naval storehouses; and round its shores are the usual anchoring places for the shipping which frequent this port. Beyond the town the harbour begins to widen considerably, and resembles a large lake with many islands upon its surface. Rio is said to be vastly improved within a few years past. The houses are built, in many parts, of hewn stone. The streets, generally straight, are well vOL. I. 


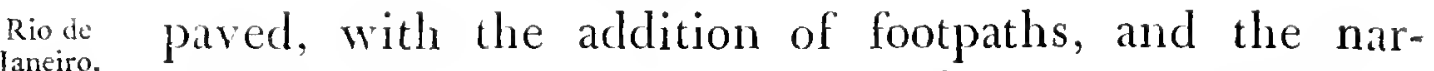

rowness of some of them proves a convenience in such a hot climate, on account of the shade. In the squares are refreshing fountains, which supply the water conveyed to them by an aqueduct of considerable length ; for, notwithstanding its name, the town of $\mathrm{Rio}$ has no river, close to it, of any note. This aqueduct is carried over vallies by a double row of arches, one placed above another: it is a structure of much ornament to the town; tho, perhaps, the water might as effectually be bronght to it by pipes. The present aqueduct does not imply an ignorance, among the Portugueze, of the hydrostatic law, that water always rises to its level; no more do the many structures of the same kind near Rome, afford just grounds for such suspicion with respect to the ancient Romans; for shew and magnificence were, as well as utility, the objects of public works. A guard constantly attends at the fountains throughout Rio, to regulate the distribution of the water, which, probably, is scanty, as there are people a long time waiting with buckets for their share. A sufficient proportion of the water from the fountain upon the quay, opposite the palace, is allotted for the use of the shipping, and is conveyed to the casks, remaining in the boats, by means of a woollen or canvas tube, called a hose, stretching from the fountion to the cask. Sir Erasmus Gower, observing that the water was re- 
markably good, and kept better at sea than any other, attributed the contrary opinion of Captain Cook to some accidental impurities remaining in the casks he filled with it.

The shops of Rio were full of Manchester manufactures, and other British goods, even to English prints, both serious and caricature. A Portugueze merchant. settled here, reflecting on the advantages gained by the country which had furnished those supplies, observed, that the prosperity both of Portugal and its dependencies redounded chiefly to the benefit of England. The benefit, probably, has been reciprocal; for every thing, at least at Rio, denoted the thriving condition of the place. The exterior appearance of individuals was that of ease and comfort; their dwellings, for the most part, were in good condition, many of them large, and generally well calculated for the climate; the magazines and markets well stored with merchandize; new buildings going on of a public and private nature; tradesmen busily employed; and, beside the aqueduct and fountains, already mentioned, with which the city was adorned, it had also some public walks; and upon the beach, opposite the palace, was built a spacious quay of granite, of which material, found indeed upon the spot, many more of the principal buildings were constructed.

This place is said, however, to be unhealtlyy; and instances of longevity are very rare. The unhealthiness 
Rio de may arise more from local and temporary circumstances,

Janeiro. than from the necessary influence of the climate. The town is situated, for the most part, upon a plain, surrounded on all sides, except opposite the harbour, by hills generally covered with thick forest trees, which not only prevent a free circulation of the air, but render it humid in the mornings and evenings ; for the moisture evaporated while the sun is up, condenses after it is set, and the descending vapour falls upon the town in the form of a fog or drizzling rain. Of these damp nights, preceded by scorching days, putrid and intermitting fevers must often be the consequence. It is too common a spectacle to see, even among Europeans, as well as native whites and negroes, that dreadful disease, the elephantiasis, which destroying the sound texture of the intcguments of the human frame, swells, and distorts, and discolours wherever it attacks, enlarging the patient's misshapen limbs to the bulk of those of the huge animal, the resemblance to whom, in that particular, occasioned the appellation this horrid disorder has received.

Not only the vicinity of the woods must be noxious, but likewise that of water, by being suffered to stagnate in marshes, near the town, tho they might easily be drained, or filled with earth. Strangers, particularly, feel their tormenting consequences in the infmite swarms of musquitoes, or large gnats, which attack them for some time alter their arrival. A long residence here, 
however, brings about some alteration in the body, which guards it against those insects; not that the skin ceases to be sensible of their sting; but either it is no longer liable to be penetrated by them, or it no longer affords juices attractive of their taste. This is not the only annoyance to strangers, in the night, at Rio; for there, as in Lisbon according to the observation of Lord Kaims, the wheels of carts are purposely constructed to make a most harsh and croaking noise, to prevent the devil from harming the cattle that are yoked to them. The fertile powers of the imagination could scarcely have devised a more effectual method of producing a horrid din.

No real or fancied danger, however, curbs the propensity of all classes of society here towards gaiety and pleasure. There are three convents for men, and two for women in this place; but little is said to be practised, in any of them, of the austerity and self-denial supposed to be intended by their original institution. Tho the conquest of the country originally was undertaken with the professed intention of converting the natives to Christianity, and ample endowments have been made for maintaining friars to preach the gospel to those infidels, yet not one of the former was now engaged in such a troublesome, unsafe, and, perhaps, hopeless enterprize. Indeed a few Italian missionaries residing here took pains to send amongst the Indians such of 
Rio de that tribe who frequent Rio, as they were able to gain

over to their faith, by presents as well as by persuasion, in order, by that means, to endeavour at converting the Indians dispersed throughout the country. Neither the friars nor the nuns of this place seemed at all disposed to rum into the gloomy excesses of clevotion: and nothing could be more sprightly than the conversation of the latter with strangers at the convent grates. The men were, certainly, not corrupted by the writings of freethinkers. No such exist in the language of the country; and few Portugueze are acquainted with any other. There were but two booksellers in Rio. Their shops contained only books of medicine and divinity. But the religious system, which held its empire there with such happy effects so long, bore now some resemblance to a machine, of which the spring, by its own internal working, was slackened at length, and wearing out. No inquisition, or tribunal of the holy office, as it is called, was established in the Brazils. The ceremonies of religion were, however, regularly kept up, and even multiplied. In the day time bells and sometimes sky-rockets amouncer, at every hour, some solemnity performing in the churches; and after sun-set the streets were crowded with processions. At every corner was stuck up, in a glass case, the image of the Virgin Mary, to which honage was regularly paid by those who passed along. 
When walking abroad, men of the lower classes generally wore cloaks. Those of the middling and fancito. higher lanks never appeared without swords. The ladies wore their hair hanging down in tresses, tied with ribands, and adorned with flowers; their heads were uncovered. They were very regular in their visits to the churches, both at matins and vespers: at other times they were generally seated at their windows or balconies. Many of them had fine dark eyes, with animated countenances. They amused thenselves, in the evenings, in playing on some kind of musical instrument, chiefly the harpsichord or guitar. The doors and windows, at these hours, were thrown open for the admission of cool air. If a stranger should stop to listen to the music, it often happened that the lather, husband, or brother of the lady who was playing, stept out and politely invited him to walk in. It was not in. frequent, also, for ladies to have bunches of flowers in their hands, which they would sometimes exchange with gentlemen as they were passing by. This might be in imitation of the Lisbon ladies, who on particular days, which are called days of intrusion, throw nosegays from their balconies at persons walking under them. Instances, indeed, of the momentary abandonment of feminine reserve may be traced to ancient times; and it must be acknowledged, that much was related of the extreme forwardness of some of the ladies 
Riode at Rio. Some of the men were accused of much worse

Janeiro. practices, in yielding to depraved and unnatural appetites.

Among the more innocent pleasures of both sexes were operas, plays, and masquerades, except when suspended on account of the indisposition of the queen of Portugal. Company often met at a public garden situated by the sea side, and at one extremity of the town. This garden was laid out in grass plats, shrubberies, and parterres, interspersed with spreading trees, together with arched alcoves or bowers of wooden framework, painted green, and decorated with passion-flowers, jessamines, and other fragrant plants. In these recesses, during the dry season of the year, the gay society of Rio, after taking exercise in the evening in the walks, and often after hearing songs and music, sat down to partake of banquets, accompanied, sometimes, by music and fire-works; and the company in this manner often protracted their pleasures far into the night. Towards the middle of the garden was a large fountain of artificial rock-work, with figures of two alligators, of no mean sculpture, spouting water into a marble bason, in which aquatic birds, well imitated in bronze, appeared sportively indulging themselves. At a little distance from this fountain was another imitation, which seemed a work of supererogation. Much expence and labour were employed to represent, in copper, painted green, 
the papaye tree, a vegetable natural to the climate, and of easy and quick growth.

On the side of this garden next the sea was a terrace of granite, in the middle of which was also a fountain, with a marble statue of a boy holding in one hand a bird, from whose bill water gushed into the bason underneath, while from the other hung a label, with the following words, sou util ainda brincando, implying his being useful even in his playfulness.

At the extremities of the terrace were two neat square buildings like, what in England are called, summerhouses. In one, the walls were decorated with paintings representing views of the harbour, and particularly of the whale fishery that used to be carried on within it, until the large black whale, which formerly frequented it, was disturbed and driven away, in consequence of the increased concourse of shipping. The ceiling of this summer-house was ornamented with various designs, and the cornice exhibited the several species of fish peculiar to the country, all in their proper shades and colours, the whole in shell-work. The ceiling of the other building was composed of devices wrought in feathers; and along the cornices were portrayed the most beautiful of the birds proper to the Brazils, curiously arranged in their natural plumage. On the walls were eight large paintings, ill executed indeed, but descriptive of the principal productions to which that vol. I. 
Rio de country was indebted for its opulence, including views Janeiro. which they were worked, and the objects of their search separated from the earth in which they were originally enveloped; of the cultivation of the sugar cane, with the processes for extracting its juice, and granulating it into sugar; of the manner of collecting the small animals which produce the cochineal, and preparing the rich dye from them; of the culture of the manioc, with the process of making cassada, which is the root of that plant after the poisonous juice it contained is expressed from it, and tapioca, which is the fine sediment deposited at the bottom of the same venomous juices, after being suffered to settle for some time; and of the culture and preparation of coffee, rice, and indigo. In this garden, which was called the passao publico, were exhibited shews for the amusement of the people; and its destination to promote the health and pleasure of the inhabitants. was expressed on two granite obelisks in the walks; on one of which were engraved the words, a saude do Rio; and on the other, o amor do publico.

Near the town, and close to the sea shore, was a garden of another kind, intended, originally, for promoting the progress of botany; but chiefly curious, now, for a small manufacture of cochineal. According to the observations made, and the information obtained, by $\mathrm{Mr}$. Barrow, "the insect which forms this dye at $R$ io, is not, 
" probably, the same as that which is noticed by Lin" næus under the name of coccus cacti coccinelliferi. The

"latter is described as flat upon the back, with black "legs, and tapering or awl-shaped horns or antennæ. "The insect of Rio is convex, with legs of a clear bright " red in both male and female, and the antemnx monili"form, or bead-like. The male is a delicate and beau" tiful insect; the colour of the whole body a bright " red, nearly resembling the pignent usually called red "lake The breast is elliptical, and slightly attached to "the head. The antennæ about half the length of the " body. The legs are of a more brilliant red than that " of the other parts. Two fine white filaments, about " three times the length of the insect, project from the " extremity of its belly or abdomen. The wings are "two, erect, of a faint straw colour, and of a very deli"cate texture. The female has no wings, is elliptic in " its form, and convex on both sides, but most so on the " back, which is covered with a white downy substance "resembling the finest cotton. The abdomen is marked " with transverse rugre or furrows. The mouth is situ"ated in the breast, having a brown beak, inclining to "a purple tint, that penetrates the plant on which the " insect feeds. Its six legs are of a clear bright red. It "becomes pregnant about twenty days after it is born, " and dies after bringing forth an innumerable off"spring, of so minute a size as to be easily mistaken 
Riode "for the eggs only of those insects. For about the space Janeiro. "of a day they remain without any appearance of life " or motion; but soon, afterwards, shew signs of anima"tion, and begin to move with great agility over the " surface of the leaf, on which the mother had depo" sited them. At this time they appear, through a mag" nifier, like small specks of red unshapen matter, thinly " covered over with a fine cottony down. In three or "four days this downy envelopement becomes visible " to the naked eye; the insect it covered increasing ra" pidly in size, till the largest is nearly equal to a grain " of rice. With this increase of size they decrease in " motion, and when arrived at their full growth, they " adhere to the leaf in a torpid state. At this period " they are taken from the plant for use; but, if suffered " to remain, will deposite their young, as already men"tioned. Amongst the clusters of these insects, enve"loped in their cotton, there are several cells, of a " cylindric form, standing perpendicularly on the sur"face of the lcaf. These cells are the chrysalides or " coccoons of the male, and out of which the wings, in "their nascent state, make their first appearance, and " are visible about three days before the perfect insect " is produced. It enjoys its existence, in that state, only " three or four days, during which it impregnates the " females. The plant, on which this insect feeds, is " called at Rio, orumbela, a species of the cactus or 
"prickly pear, and, probably, the cactus opuntia of “ Linnæus. The leaves are thick and fleshy; the upper

" side more flat, or even concave, than the opposite; " are somewhat of an oval form, growing without stalks, " but rising one immediately from the other's edge, as "well as from the stem, and armed with round and ta" pering prickles, about an inch, or nearly so, in length. "These plants grow, sometimes, to the height of twenty "feet; but they are generally prevented from rising " above eight feet, which is a size more convenient to " the manufacturer, and at which the leaves are thought " to contain juices most nutritious to the insects. The " young leaves are of a dark green, but incline towards " a yellow colour as they advance in age. The internal " substance of the leaf is of the same colour with its ex" terior surface. It is easy to discern when any insects " are upon the plant; they first appear like a white " powder thinly spread upon its flat or hollow side, " which is marked, soon afterwards, with small protu" berances of the same white downy substance, already " said to resemble the finest cotton. "Another insect is found upon the cactus, and is " supposed to feed upon the coccus or cochineal insect; " in its perfect state it bears a strong resemblance to a "four-winged insect, called ichneumon; but, on exa" mination, is found to be a fly with two wings only. 
Riode "The larva, or caterpillar of this fly, insinuates itself Janeiro. " into the cotton with which the coccus is enveloped, " and is scarcely distinguishable from the latter, except "that it is a little more elongated, with somewhat "longer legs, and that the cotton does not stick to it, " whereas from the coccus it is with difficulty sepa" rated. When this fly is prepared to change its skin, " it creeps out of the cotton upon the naked part of the "leaf, increases quickly in its bulk, and its colour " changes from that of a bright red to a clear yellow, "with rings of brownish spots about its body. In a "few days it becomes torpid; but, soon afterwards, " contracting its rings with violent agitation, it deposites " a large globule of pure red colouring matter; after " which it immediately hangs itself upon the prickles " of the leaf, and becomes a chrysalis, out of which " issues, shortly, the perfect fly. From the circum"stance of the colouring matter being deposited by this " insect, previous to its change into the chrysalis state, " it might be inferred, that any other insect, feeding on " the same plant, would be productive likewise of the "same colouring matter. Yet the leaf itself constantly "gave out, only, a transparent gelatinous fluid, per" lectly colourless. The fruit, indeed, or fig of the cactus, " when ripe, contains a scarlet juice, which colours " some of the excretions of those who eat it. The plate, 
"No. 12, will shew, better than any written description

"can, the respective forms of both insects, as well as

" the plant on which they are found.

" The profit to the Portugueze at Rio, from the co" chineal, is inconsiderable, owing to an error in the "preparation. Twice or thrice a week the slaves, ap"propriated to this employment, go among the cactus "plants and pick off, carefully, with a bamboo twig, " shaped somewhat into the form of a pen, every full " grown insect they can find, with many not yet ar" rived to their perfect state; the consequence of which " is, that the plants are never half stocked with insects, " many of the females being destroyed before they had " deposited their young. The natives of Mexico pursue " a method very different. As soon as the periodical " rains are over, and the weather is warmer, as well as " drier, they fix, on the prickles of the cactus leaves, " small parcels of the finest moss, serving as nests to " contain, each, ten or a dozen full grown female in" sects. These, in the course of a few days, bring forth " an innumerable tribe of young, spreading themselves "over the leaves and branches of the plant, till they " become attached to those spots which they find most "favourable for supplying nutritious juice; where, "soon acquiring their full growth, they remain mo" tionless, and then are gathered off for use; a sufficient " number being always left for the production of new 
Riode "broods. The insects are soon converted into cochi-

Janeiro. "neal by a very simple process; but if, in corporal suf"ferance, the poor beelle feels a pang as great as when a giant "dies, this process is not more simple than it is cruel. "The insects, which were collected in a wooden bowl, " are thickly spread, from thence, upon a flat dish of " earthen ware, and placed alive over a charcoal fire, " where they are slowly roasted until the downy cover" ing disappears, and the aqueous juices of the animal " are totally evaporated. During this operation the in" sects are constantly stirred about with a tin ladle, and, "sometimes, water is sprinkled upon them, to prevent " absolute torrefaction, which would destroy the colour, " and reduce the insect to a coal; but a little habit " teaches when to remove them from the fire. They "then appear like so many dark round reddish grains, " and take the name of cochineal, preserving so little "the original form of the insect, that this precious dye "was long known and sought in Europe before natu" ralists had determined whether it was an animal, ve" getable, or mineral substance. The garden at Rio " does not, annually, produce above thirty pounds " weight of this commodity; tho by proper treatment, " from the same number of plants, ten times the quan"tity might be obtained. At Marica and Saquarima, "both places contiguous to Gape Frio, are considerable s plantations of the cactus, which are propagated easily 
"from cuttings set into the earth during the cold and " rainy season, tho they afterwards thrive least where

" excluded from the sun. The insects breed and are " collected, in dry weather, from October until March. "The preparation of cochineal is encouraged by the " trade being laid open, which had formerly been a "monopoly to the crown."

Beside this species of manufacture in the neighbourhood of Rio, another, of which an exclusive privilege was given to a company paying one-fifth of its profits to the crown, was carried on within the harbour, and opposite to the town. Thither was brought, for the purpose of being converted into oil, the blubber or firm fat of the black whales, no longer, indeed, caught, as formerly, close to it, but on shores more free from the busy haunts of men. The whale-bone or cartilages of the jaw were, also, properly separated and cleansed here, before they were sent to Europe. The white whale, which supplies the spermaceti, is often sought for as far as the Pacific Ocean. An English ship from those seas was lately come into Rio harbour for refreshments. She had taken sixty-nine whales, each worth, upon an average, two hundred pounds. Some are of a size to fetch one thousand. The recent discovery that the muscular part of animals is convertible into a matter similar to spermaceti, may, perhaps, hereafter diminish the profits of those distant adventures. 
Riode In another part of the harbour of Rio, not far from the town, at a place called Val Longo, are the warehouses for the reception, and preparation for sale, of the slaves imported, chiefly, from Angola and Benguela on the coast of Africa. This spot was appropriated to the purpose of cleansing, anointing, fattening, rendering sleek and saleable, and concealing the defects of, this class of beings, who scemed little sensible of the humiliation of their condition. About five thousand were usually sold, every year, at Rio, out of twenty thousand purchased for the whole of the Brazils. The average price was about twenty-eight pounds sterling each. Before they were shipped from Africa, a disty of ten thousand reis a head is paid to the queen of Portugal's agent there. The whole amounted to about sixty thousand pounds a year, which goes into her privy purse, and is not considered as part of the public revenue. In the whole of the Brazils there were supposed to be, at least, six hundred thousand slaves, born in Africa, or descended from these who were. The whites were computed to amount to about two hundred thousand. The proportion of blacks to whites in the town of Rio was supposed to be much greater, there being in it at least forty thousand of the former, including such as had been emancipated, (o about three thousand of the later.

Whatever may be the sufluring of slaves, moler task maters mpon plantations, these resiling in the town 
wore no appearance of wretchedness. The human frame feels indeed fewer wants, and is therefore exposed Jantiro. to ferwer miseries, in a warm climate than in a cold one. In the latter, a dwelling to shelter from the inclemency of the weather, garments for the body, and artificial heat in winter, are almost as necessary as food to any thing like comfortable existence. These articles may, with less inconvenience, be dispensed with, or a sufficiency of them more easily be provided, in tropical climates: even as to food, the spontancous bounty of nature supplies it more readily in warmer than in colder countries; and in the latter, fermented liquors, to be procured only by art and labour, are sometimes requisite; whereas, within the tropics, every stream supplies what, in most cases, is there more grateful, as well as salutary. The West India slave has not, therefore, much to envy the peasants of many European kingdoms. The plantation slaves in the Brazils have two days out of seven for their own purposes, which is more than is allowed in the West India islands. The slaves in the Brazils were upbraided for being addicted to stealing and lying; which indeed appear to be the vices of their condition every where. This condition is hereditary through the mother, and is not confined to colour. There were miny at Rio in that state, of every tinge between black and white. The Africans seemed naturally of a gay and active disposition, easily recon- 
Riode ciled to their situation, and enjoying fully whatever Jareiro. share of pleasure happened to come within their reach. They seldom sought intoxication as a resource against poignant feelings, or for the purpose of stifling reflections upon their misery. They were fond of dancing and music; and the black drivers of hackney chaises at $\mathrm{Rio}$ were, in the intervals of leisure, often heard playing on the guitar upon their stands. Many slaves were the property of the crown, of whom about ten thousand were employed in the diamond mines, where a stone had been lately found larger and more precious, it is said, than any that the Empress of Russia has purchased, or indeed that have hitherto been discovered. Several slaves were also attached to convents. The Benedictines alone had a thousand upon their plantations. The monks of this order, being very opulent, exercised offices of charity; but delighted more in those of hospitality. They pressed the Chinese interpreters, belonging to the Embassy, as priests of the same religion, to reside in the convent with them, during their stay at $R$ io; and entertained them very handsomely. The Benedictine fathers, in the number of their slaves, had an opportunity of observing that the offspring, from the connection between blacks and whites, were generally endowed with much intelligence and ingenuity. Some of these they bred up carcfully, and instructed with such success, as to think themselves no longer obliged 
to send persons to the universities of Portugal for at literary education. These friars mentioned, with some degree of triumph, that a person of a mixed breed had been lately promoted to a learned professorship at Lisbon.

The original inhabitants of the Brazils were found not to be reducible to a state of slavery, or even to the domestic habits of civilized society. Children of some of those Brazilians had been taken into Portugueze families, and uncommon pains bestowed upon their education, out of motives of speculative curiosity, as well as those of benevolence and humanity; but so intractable, it is said, their nature proved, that they constantly returned to their original habits of savage life, without retaining any of the principles which might restrain their passions or caprices. These people, tho poor, seldom offered themselves for hire, and were as seldom coveted by the Portugueze, except for rowing boats, in which they were remarkably expert. In their persons they generally were somewhat under the middle size, muscular, stout, and active, of a light brown complexion, black, strong, uncurling hair, with very little beard, and long dark eyes, which discovered no mark of imbecillity of intellect. Nor did the turn of their features convey any character of meanness or vulgarity; but, on the contrary, their looks and expression were intelligent and distinct. They seemed to find an irresistible charm 
Rio de in the enjoyment of boundless freedom; and, nomishing,
Janeiro. laneiro. probably, an hereditary and implacable antipathy to the invaders of their country, they shun and withdraw from the considerable settlements of the Portugueze; but massacre individuals, without remorse, wherever they are found scattered or unprotected. Much of the coast between Rio and Bahia was still inhabited or frequented by them, which circumstance prevented any regular communication, by land, between those two places.

In the vicinity of the town of Rio the roads were not passable many miles for carriages. In an excursion from thence to the westward by $\mathrm{Mr}$. Barrow and two other gentlemen of the Embassy, accompanied by a Portugueze inhabitant of Rio, it appeared that little industry was exerted thereabouts in the cultivation of the soil, or improvement of the country. It consisted chiefly in raising garden vegetables for the whites, and rice and manioc for the blacks. Wheat was found to grow in other parts of the Brazils, with an increase beyond what is known in Europe. The corn mill, used by them, was of a simplicity of construction worthy of being described. One of them happened to be erected on a stream close to the forest, which the gentlemen of this party meant to penetrate: a wheel, a few feet only in diameter, was placed horizontally, much below the current of a stream, as it fell from a steep bank, and was received in hollows, ten or twelve in number, so 
obliquely scolloped into the upper rim of the wheel, as to impel it to a quick rotatory motion, while its upright shaft, passing through an opening in the centre of an immoveable millstone above the wheel, but of a narrower diameter, was fixed to a smaller millstone, which, forced round with the motion of the wheel and dependent shaft, crushed between it and the larger stone beneatl, the grain insinuated between them from a hopper. Thus that effect was produced, by the means of one wheel only, which is generally the result of a much more expensive and complicated machinery. It is said that a similar mill is in use in the Crimea.

The forest, already mentioned, was found to abound in palms and mastic wood, also mangoe and gouyava trees, and ferns growing to the size of trees, beside many other vegetables, never observed before by those who were then travelling through it. Of these, it is to be hoped that, a full description will soon appear in a botanical work, upon the plants of this country, promised by a Franciscan friar who resided long in Rio, and gives, quaintly enough, the name of Flora Fluminensis to his intended publication. The ipecacuanha plant, growing at St. Catharine's within the government of Rio, will there also probably be described. At present, tho its root hath been so long in use, as a valuable at ticle in medicine, to what class, or kind, or species, in the botanical system it belongs, is not yet accurately known. At the request 
Rio de of one of the gentlemen of the Embassy a messenger was Janeiro. sent to St. Catharine's, for a specimen of it. What was brought was an herbaceous plant, about three feet high, with a single stem, and lanceolated leaves; but as it was not then either in flower or seed, its proper character conld not be ascertained.

There was at Rio a collector of birds and insects, who, among other curious articles, had the palamedea, or anhinga, with a strong nail or spur at each flexure of its wings, and a horn, of about six inches length, growing from its forellead; a bird very rarely to be seen in the cabinets of Europe. The size and vivid hue of many of the flowers, throughout the forest, and the gaudy plumage of the birds, which came occasionally in sight, were indeed striking. The woods, it is said, abound in snakes, some extremely large and formidable. But their hissing noise sets the hearer on lis guard, and they seldom, without provocation, advance to an attack. No sound, however, was heard to alarm the present travellers. The people of the country go about, indeed, every where with all the indifference of security; their minds little affected by the apprehension of an evil, tho near to them, and of which they had often heard, as they had never experienced it in their own persons: in like manner as the danger, for example, from the bite of mad animals in Europe, notwithstanding the dreadful instances which, at a particular scason, are known 
frequently to happen, disturbs not the thoughts, nor interrupts the occupations or amusements, of those most exposed to so dreadful a calanity.

The forest, above described, led to the cultivated valley of Tijonca, situated, as it were, in the bottom of a funnel, being surrounded on all sides by mountains, excepting to the sonthward, where a small opening admitted an arm of the sea. The valley was watered by a clear stream, which, on first entering into it, was precipitated down a steep and broad rock of granite, forming a magnificent cascade. Very little labour appeared necessary in the plantations of Tijouca. It was no uncommon sight to meet with indigo, manioc, coffee, cacao or chocolate trees, sugar canes, plantains, and orange and lime trees, all growing promiscuously, and some spontaneously, in the space of twenty square yards. Coffee and indigo were the principal objects of attention. The temperature of the valley was excessively hot, owing to its confined situation, and the reflection of the sun's rays from the sides of the mountains, which in many places were rocky. Fahrenheit's thermometer, about four in the afternoon, stood, in the shade, at eighty-eight degrees. The party took shelter at the house of a friend of their Portugueze companion. Here they were hospitably treated, and passed the night. The warmth of the weather removed all necessity of bedding. A neat woven voL.I. 
Rio de mat with an elastic pillow were placed upon a platform, Janeiro. raised somewhat from the floor; and there the guests reposed, with no covering but night-gowns.

Several districts of the government of $\mathrm{R}$ io produced cotton, sugar, coffee, and cacao or chocolate, rice, pepper, and tobacco, in great abundance. That of Rio Grandé yielded plenty of excellent wheat. The vine grew in great perfection; but the grape is not suffered to be pressed for wine, as such a process might interfere with the sale of the same article from Portugal. The whole of the Brazils was divided into eight independent governments, beside that of Rio de Janeiro, of which the governor retained the name only of viceroy of the Brazils. The others were those of Para or Amazons, Maragnon, Fernambucca, Bahia, Santo Paulo, Matto Grosso, Minas Geraes, and Minas Goyaves. Formerly Bahia dos Todos os Santos was the principal seat of government and chief mart for commerce in the Brazils; but the discovery and improvement of the gold and diamond mines, within about one hundred leagues of Rio de Janeiro, and communicating immediately with it, gave a decided preponderancy to the latter. But all the provinces were growing fast into opulence and importance. They manufictured, of late, several of the most necessary articles for their own consumption; and their produce was so considerable, that the balance of trade began to 
be already in their favour; and remittances of bullion Riode were made to them from Europe, in return. for the over- Janeiro. plus of their exports beyond their imports.

In the administration of the Marquis de Pombal, so long prime minister in Portugal, these colonies were delivered from some monopolies and restraints which had contributed to depress them. The parent state was again accused by them of jealousy at their present progress towards wealth, and consequent power and independence; which it was endeavouring to smother and repress by new restrictive and injurious regulations. But the people began to consider themselves as children too robust to be strangled in the cradle; and that the crown of Portugal must either transfer the seat of its empire to the Brazils, or leave them to take their chance, to unfold and exert their native powers, uninfluenced by the authority, and unrepressed by the terror, of a distant sceptre. They seemed to enquire, with an uncommon degree of interest, into the progress of the French revolution, as if they foresaw the possibility of a similar event among themselves. This was, however, before the accounts of the sanguinary horrors, which took place in the progress of it, had disgusted every feeling mind from any inclination to follow its example.

The project of removing the seat of the Portugueze government to the Brazils was once, in fact, seriously in contemplation with the Marquis de Pombal, when that 
Rio de country was invaded by the Spanish forces in 1761,
Janeiro. Janeiro. and calculations were madie, and precautions taken, as to the number of vessels necessary to transport across the Atlantic the royal family, with the principal officers of the court, and their several attendants. This project vanished with the danger that gave rise to it; and the Brazils continued to be considered as a colony destined, exchusively, to enrich the parent state.

The duties which the agents of the latter levied upon the importation of goods from Lisbon and Oporto, at Rio de Janeiro, were twelve per cent. upon the value of each article. The chief duties paid at Lisbon, on the commodities of the Brazils, were as follow: upon gold, one per cent.; coffee, eight per cent.; sugar, rice, and skins, ten per cent.; indigo, twelve per cent.; planks, seventeen per cent.; and rum, four dollars on every pipe of one hundred and eighty gallons. All that kind of wood, commonly called red or Brazil wood, and also all large ship timber was claimed as the property of the crown. One-fifth of all the gold extracted from the mines was exacted also by the government; and whenever any diamonds happened to be found in a gold mine, it was no longer allowed to search there for that metal; all diamond mines being seized as, exclusively, belonging to the crown. Every manulacture amongst them was said to be discouraged by the government; tho many, already, were established. Such was the change 
wrought lately there in the minds of men, that some noble Portugueze disclained not to be concerned in those

manufactures. One gentleman of considerable rank had lately erected a rice work close to Rio, in which he employed sixty slaves in preparing that grain for use. He had been a military officer, and could never have taken greater pleasure in shewing the regular evolutions of his soldiers under arms, than he feels at present in shewing the mills by which he frees the grains of rice from the pellicle closely adhering to them. However, there appeared nothing particular in his method, except the use of siliceous sand, of which the small sharp angles are found to assist materially in the operation; which being over, the sand was easily separated from the grain by sieves, with apertures sufficiently large to suffer it to pass through them, but impervious to the grains of rice. The same gentleman bred his eldest son to commerce, as likely to be the most important profession in the Brazils; nor did this disposition appear singular. Trade was already rising there above the many impediments thrown in its way from home, and even several mechanical employments began to be exercised.

The people of Rio had been, of late, prohibited from working up even the gold of their own mines; and the tools and instruments, used by the artificers for such purposes, were seized and confiscated by the strong hand of arbitrary power. Yet notwithstanding the mo- 
Rio de nopolies, prohibitions, and heavy taxes, the whole reJaneiro. venue from the Brazils, was not said to be equal to a million sterling, of which the expences of their government consume about a third. The taxes were severely felt, particularly in the interior provinces, where the carriage and transit duties increased the price of every article so enormously, that a bottle of port wine, for instance, cost ten shillings sterling to the consumer.

The rising spirit of the people, little patient of the hardships imposed upon them by the mother country, led, not long since, to a conspiracy at Minas Geraes, remarkable, and indeed formidable, as some of the principal officers of the government there, both laity and clergy, entered into it. It appears that the troops sent from Portugal were seldom afterwards called home. The civil officers, except the viceroy, were allowed also to be stationary. These persons, tho natives generally of Portugal, soon changed their original affection for the mother country into an attachment to that, where they were likely to spend their days; and were sometimes tempted to sacrifice to their own, the interest of their employers. Their views, on the present occasion, were discovered in time to prevent the intencled fatal consequences; but it was found necessary to march a considerable number of troops, from the coast, into the back country, to maintain tranquillity: good policy, as well as clemency, confined capital pu- 
nishment to one only of the conspirators. The rest were banished to the Portugueze settlements on the coast of Africa.

Whatever difficulties the Portugueze may be likely to encounter in securing their American possessions against internal enemies, they seemed to have taken no mean precautions against any foreign attack. With regard to Rio, Captain Parish remarks that "Portugal, " from the relatively low state of its military and marine " establishments, might find it impracticable to convey " succour to that distant colony, after being once engaged " in a war with any European power; and must, there"fore, provide for its defence independently of any " hope of further assistance. The best constructed for"tifications would, perhaps, be insufficient to answer " such a purpose, for tho amply garrisoned and sup" plied, it could not be expected to hold out many " weeks against a well conducted siege, undertaken " with an adequate force. It is perhaps on this account " that the Portugueze have not erected here any very " considerable work. The defences of the place consist "in several small forts and batteries, detached from each " other, but so disposed as to throw every impediment " in the way of an enemy, on his entering the harbour, " and on his subsequent attempts upon the shore. Should " he, however, succeed in both, the military establish" ment of the country is such as to enable it, with a 
Riode "good position, to face him in the field. This esta-

Janeiro. " blishment consists of two squadrons of cavalry, two "regiments of artillery, six regiments of infantry, two " battalions of disciplined militia, beside above two " hundred disciplined free Negroes; making, in the " whole, a body of, at least, ten thousand men, exclu" sively of a very numerous registered, but undisci" plined, militia, of whom a considerable proportion is " in the city and its neighbourhood. The entrance of "the harbour, which is scarcely a mile from point to " point, is crossed in every direction by heavy batteries. "Ships, too, in returning their fire, would have to labour " under the disadvantage of a swell, occasioned by the " bar which runs across, but outside, the harbour's "mouth. The fort of Santa Cruz is a work of some "strength, and the principal defence of the harbour. "Its general height is from twenty-four to thirty fect. "It mounts twenty-three guns towards the sea, and " thirty-three to the westward and northward. It stands " upon the low point of a smooth rock, from the body " of which it is separated by a fissure ten or twelve feet " in width. It is flanked by batteries to the eastward " and westward; and is seen and protected by a regular "front for musquetry, which runs between the hills. "The guns of the fort of Santa Cruz, and others, " were fired on the birthday of the Queen of Portugal, "and, from their report, were judged to be heavy 
"pieces, not less, perhaps, than four-and-twenty pound-

"ers. The defence of the city of Rio is supposed to

" depend, chiefly, on the works erected on the Serpent " island. The highest part of" it, which looks towards "the town, is about eighty feet above the water. On " it is constructed a small square fort. The island lowers "gradually on the eastern side to the water's edge, and " is occupied by an irregular stone line, having occa"sional flanks. It is, however, low, in some parts not " more than eight feet above the rock; and it has no " ditch. The length of the island is about three hundred "yards: it mounts forty-six guns, twenty of these facing " the south and south-east, and the remainder looking " to the opposite points. The parapet wall, now build" ing along the front of the town, will afford a good line "for musquetry and light guns."

Whatever may be the political fate of Rio de Janeiro, its natural appearance must always attract notice. It certainly presents bold features to the view. Its harbour, mountains, woods, and rocks, seem to be upon a grand scale. Its productions flourish with the vigour and freshness of youth. Nothing looks naked, arid, or decaying.

Doctor Gillan noticed that " the high conical rocks, " at the entrance of the harbour of Rio, and the sur" rounding hills, were all of granite, in which the only" " circumstance remarkable was the large proportion VOL.I.

B b 
Rio de "of feld-spath it contained. About two miles within "the harbour, on the south-west side, was one high " rock, entirely composed of columnar masses, bearing " the resemblance of basaltes. It rested upon clay. In "all the quarries of granite it is found incumbent upon "clay and sand. There were three species of granite "here. The first, red-coloured, soft, and shivery. The "second, deep blue-coloured, harder, and of a closer "texture; and the last, of a whitish shining colour, "containing much of mica, and little feld-spath; its "texture soft, and incapable of a good polish."

The gentlemen of the Embassy, in their observations, were indulged with greater liberty than is usually allowed at Rio to any strangers. The viceroy sent his own barge to convey them round the harbour, and made an offer of any other civility in his power. He testified a desire of shewing every mark of respect and attention to the Embassador; received him with distinguished honours on his coming on shore; provided proper accommodations for him and his suite; and offered a guard to attend upon his person. His Excellency, who had been much indisposed at sea, recovered his health on shore within a fornight; and, anxious to arrive at the place of his destination, still so distant, returned on board belore the ships were entirely provided with all the necessaries for the prosecution of the voyage. The Portugueze agent, however, now got every hing ready very quickly. 
Wood, water, and provisions were supplied in such quantities, as to supersede the necessity of stopping at $=$ the Cape of Good Hope ; and to enable the ships to continue their route, with little delay or deviation, to the Chinese seas. They weighed their anchors on the seventeenth of December, 1792.

Ships sailing from Rio de Janeiro seldom work out of the harbour against the wind blowing from the sea, but move in the mornings, for the benefit of the land breeze, at which time the harbour empties itself of the mass of water thrown into it by the sea wind at night. This reflux is stronger, often, than the wind. Its course is along the bays on the eastern shore, and it afterwards sets upon the point of Santa Cruz. The Lion was carried into that part of the stream where it ran with the greatest impetuosity. The ship bore directly towards the rock, and, in continuing to move, must have struck upon it speedily. The alarm instantly spread among those who best could judge of the imminence of the danger. One of the officers let fall the words, there is an end to the expedition! To those who had set their hearts on its accomplishment, which was indeed the case of most persons embarked in the undertaking, no spectacle could be more afflicting than the prospect now exhibited, and no consequence more painful than what was foreseen to follow from it. The ship was approaching to the rock so nearly as to be already in the wash of the 
Rio de sea, or in the waves which dash against the shore, when, laneiro. fortunately, the anchor held, which had been lowered from the ship, and saved her. She was afterwards warped out by boats. On sounding near the rock, it was found to be nearly perpendicular, and that the ship's sides might have struck against it, without the keel's touching any bottom. 


\section{CHAPTER VI.}

PASSAGE TO THE SOUTHERN PART OF THE ATLANTIC, AND OF THE INDIAN OCEAN. VIEW OF THE ISIANDS OF TRISTAN D'ACUNHA IN THE FORMER, AND OF THOSE OF ST. PAUL AND AMSTERDAM IN THE LATTER.

IN a former chapter it was observed that the wind, which in European climates is found to be so variable, that an idea of inconstancy is generally conveyed by a comparison with it, ceases to have that quality between and near the tropics. The steady motion of the atmosphere in those parts, with an uniform tendency from the eastward to the westward, which renders voyages in the latter direction so certain and expeditious, becomes a most serious obstruction to a return by the samc route. It was the observation of these unchangeable gales, that so much alarmed the crew of Columbus's ship, when he went in quest of the western world. They feared that this wind, tho so favourable to his present pursuit, would prevent them from revisiting their country; and their resentment was so strongly excited against him, that all the firmness of his mind, and resources of his genius, were necessary to preserve him from its fatal consequences. On his return home he judged that, instead

Passage to the Indian Ocean. 
Passage to the Indian

Ocean. of attempting to stem, in the same track, the force of winds so constantly adverse to his retrograde course to Europe, it would be expedient to proceed nearly upon the same meridian, from the equator, till he could get again into the variable winds, of some of which he might avail himself, to gain the port from whence he originally had sailed. And this is the rule which since has been mostly followed in voyages to the eastward. Tho the influence of the land of South America often counteracts, in some degree, the general tendency of the trade winds, that effect is more conspicuous at a still greater distance than $\mathrm{R}$ io from the line; and the Lion and Hindostan removed accordingly, from thence, in a southerly direction, till they arrived in thirty-seven degrees of southern latitude, where the westerly winds are found to prevail in most seasons, and to favour a direct course to Asia. In those latitudes distant from the line, the winds are frequently as boisterous as they are variable. Every precaution was taken to guard against their ill effects, by putting the ships, while they remained in the harbour of $\mathrm{Rio}$, in a proper condition to bear foul wather, by all the means which art could furnish, and some of which could not be applied at sea. It is certain, that few of the misfortunes which happen upon that elcment really are inevitable. From neglect, or dingerous conomy, vessels frequently venture out, iil-found, upon the occan, as if it were not capable of 
being disturbed by storms; and are in danger of perishing, if in this state they are overtaken by bad weather.

Every part of the Lion was carefully examined; whatever injury, however trifling, had been suffered in the course of the voyage out, was solidly repaired. The standing rigging, or those rope-ladders by which the sailors ascend to the summits of the masts, and which, being firmly fixed and stretched on each side from the hull or body of the ship to the masts' sides, keep them steady in their places, is apt to become slack by the influence of the tropical heat. This was set up, or contracted anew, to answer its original purpose. Some of the suspected masts were changed, and others fished, as it is called, or strengthened by plank s fastened by cordage round them. The sails which had been thinned and weakened by use, and were no longer fit to resist rude blasts, being now properly fair wealler sails, were laid by for similar occasions, and replaced by canvas yet unworn. These precautions were not found useless; and prevented disasters which the sudden gusts, that in this part of the voyage were experienced, would otherwise have probably occasioned.

During the continuance of strong gales, gentlemen who had suffered by sea sickness, and whose constitutions were so peculiar as not to be much fortified by the habit of being at sea, were again affected by the increased agitation of the ship by the waves. One person, 
himself of the medical profession, and who had observed others labouring under the usual attack and symptoms of sea sickness, perceived a few circumstances so uncommon in his own case, that he did not think it altogether uninteresting to describe his situation. "He " felt," he said, " at first a sickness in his stomach, fol" lowed by a reaching, when he threw up whatever he " had taken into it; then green, and afterwards yellow "bile, to which succeeded a thick, mucilaginous, in" sipid fluid, which he considered to be the gastric " juice, and, lastly, grumous blood. Before he vomited "the last, he felt a sensation as if his stomach were " twisting together, and which motion, he supposed, " produced the hemorrhage. Had the blood proceeded " from the lungs, he judged, it would have been spu" mous, or mixed with air bubbles. He felt constantly " a nausea in his mouth; his salivary glands swelled, " and the saliva became thickened and vitiated. His " mind grew indifferent to all things, either past or fu" ture, and even to his existence. Regret and hope were " equally extinct within his breast. His head felt light " and sore, and as if its sutures were separated from each " other. It likewise ached; and he had alternate sensa"tions of violent heat, and chilling cold. He thought " he felt the inversion of the peristaltic motion, and of " its actual tendency upwards from the intestines to the "mouth. Whatever he swallowed he returned with no 
"alteration of it in the stomach. The bare mention of "food, solid or liquid, was loathsome to him." Another

of the passengers continued, likewise, but in a less degree, to be affected by every violent motion of the ship. The rest not only bore the voyage well, but were, in general, healthy, and in good spirits. Their minds were not corroded with present cares; and they had an object of desire constantly present to their imagination, and to which they were every day approacling. It was soon discovered, that the only way to avoid that languor, which hangs upon passengers sometimes for want of occupation, was for each to fix to himself a task, the performance of which would employ every moment of his leisure. The youngest of them followed the example of the midshipmen, in endeavouring to become acquainted with every mast, yard, rope, and sail belonging to the ship, as well as the manoeuvres of her management, and the theory of navigation. He was employed likewise, as well as a few other gentlemen, in obtaining from the Chinese interpreters, some instruction in the language of the country where they hoped to arrive soon; most of the rest had recourse, for amusement and information, to books, of which the Embassador, Sir Erasmus Gower, and another person on board, had provided a considerable store. Most moments of recreation were passed upon the quarter-deck, voL. I.

C c 
Passage to where every one appeared with all the regularity and the Indian decorum of a public walk.

In a ship of war the rank of every person belonging to it is maintained with appropriate distinctions, and proper subordination constantly observed. That side of the deck which the current of the wind frrst strikes, or what is called the windward side, is always considered as the post of honour. This side is reserved for the captain, who is an absolute monarch, while on board; and also for his lieutenants, the master, surgeon, purser, and cabin passengers. The opposite, or leeward side, is free for midshipmen, surgeon's and master's mates, and a ferv other petty officers; while the main deck and forecastle, or fore part of the ship, are occupied by the remainder of the crew. On most fair evenings the Embassador's band of music, consisting of very good performers, and sometimes joined by amateurs, entertained a numerous audience, with little more interruption than in a public concert-room ashore. The manoeuvres of the ship were generally carried on with little noise; and very seldom with any of those imprecations which formerly were deemed necessary to enforce obedience.

The navigation was continued in the parallel of thirtyseven degrees for some days, with a favourable breeze, as was expected, from the westward. On the thintyfirst of December: 1792 , the islands of Tristan d'Acunha 
came in sight, the largest bearing that name only; the others subdistinguished by the appellations of Inaccessible, and Nightingale islands. "Inaccessible," as Sir Erasmus Gower observes, "seems to deserve that name, "being a high, bluff, as well as apparently barren, " plain, about nine miles in circumference, and has a "very forbidding appearance. There is a high rock " detached from it at the south end. Its latitude is "thirty-seven degrees nineteen minutes south; its lon" gitude eleven degrees fifty minutes west from Green"wich. This rude looking spot may be seen at twelve " or fourteen leagues distance. Nightingale island is " irregular in its form, with a hollow in the middle, and " is about seven or eight miles in circumference, with " small rocky isles at its southern extremity. It is de"scribed as having anchorage on the north-east side. "Its latitude is thirty-seven degrees twenty-nine mi" nutes south; and longitude eleven degrees forty-eight " minutes west from Greenwich. It may be seen at seven " or eight leagues distance. The largest of those three "islands, which, comparatively, may be called the "great isle of Tristan d'Acunha, is very high, and may "be seen at twenty-five leagues distance; it seems not "to exceed in circumference fifteen miles. A part of" "the island towards the north rises perpendicularly "from the sea to a height apparently of a thousand feet, "or more. A level then commences, forming what 
Tristan " among seamen is termed table land, and extending d'Acunta. " towards the centre of the island; from whence a co" nical mountain rises, not unlike in appearance, to " the Peak of Teneriffe, as seen from the bay of Santa "Cruz. Boats were sent to sound, and to examine the " shore for a convenient place to land and water. In con"sequence of their report, the Lion stood in, and came to " anchor in the evening on the north side, in thirty "fathoms water, one mile from the shore; the bottom " black sand with slime; a small rock, off the west " point, bearing south-west by south, just open with " the western extremity of the island; a cascade, or fall " of water, emptying itself upon the beach, south by " east. All the shore, from the southern point to the " eastern extremity, appears to be clear of danger, and " steep, except the west point, where there are breakers " about two cables' length, or near five hundred yards, "from the shore. The ship, when anchored, was over" shadowed by the dark mass of that portion of the island " whose sides seemed to rise, like a moss-grown wall, im" mediately from the ocean. On the right the elevation "was less rapid, and between the rising part and the " sea was left a flat, of some extent, covered with sedge"grass, interspersed with small shrubs, which, being " perfectly green, looked, from the ship, like a pleasant " meadow, watered by a stream that fell, afterwards, from "its banks upon the beaclı. The officers, who went 
"ashore, reported that the casks might be filled with fresh

" water by means of a long hose, without moving them

"from the boats. The landing place, thereabouts, was "also described as being safe, and superior to any other " that had been examined. From the plain the land rose, "gradually, towards the central mountain, in ridges " covered with trees of a moderate size and height. The " coast abounded with sea lions and seals, penguins and "albatrosses. One of the latter was brought on board, " his wings measuring ten feet from tip to tip; but " others are said to have been found much larger. The "coast was covered with a broad sea weed, several 
Tristan "fathoms long, and, deservedly, by naturalists, termed d'Acunha. "gigantic fucus. Some good fish was caught with the " hook and line.

"The accident of a sudden gust, by which the anchor "was, in a few hours, driven from its hold, and the " ship forced out to sea, prevented the island from " being explored, as was intended. It is probable that " had the Lion anchored in twenty, instead of thirty "fathoms water, the anchor would have held firmly. "Some advantage was obtained, however, from coming " to this place. The just position of those islands, in " respect to their longitude, was ascertained by the mean " of several time-pieces, to be about two degrees to "the eastward of the place, where they are laid down " in charts, taken from observations made at a period "when the instruments, for this purpose, were less ac" curate than at present. The spot where the Lion an" chored was determined, by good meridional observa" tions, and by accurate time-pieces, to be thirty-seven "degrees six minutes south latitude, and eleven degrees " forty-thiree minutes west longitude from Greenwich. "The compass had seven degrees of variation westward "from the pole. Fahrenheit's thermometer stood at sixty"seven degrees. It was useful also to have ascertained " that a safe anchorage, and plenty of good water, were "to be found here. Those islands are certainly worthy "of a more particular enquiry; for they are not fifty 
"leagues from the general track of vessels bound to "China, and to the coast of Coromandel, by the outer

"passage. In war time, an excellent rendezvous might " be settled there, for ships that wanted no other supply " but that of water. When circumstances require par" ticular dispatch, it is practicable to come from England " to Tristan d'Acunha, without stopping in the way; " and afterwards to the end of the voyage to India or "China."

These islands are separated by a space of about fifteen hundred miles from any land to the westward or northward of them. They are situated in that part of the southern hemisphere, in the neighbourhood of which a continent, to balance the quantity of land in the northern hemisphere, was once expected to be found; but where it has been since discovered that there is none. Of what extent, however, the bases of those islands are under the surface of the sea, cannot be ascertained; or whether they may, or may not, be sufficient to make up for the defect of land appearing above water. Navigators report, that to the eastward of them are other small islands, differing not much in latitude, such as Gough and Alvarez islands, and the Marsouines; as well as extensive shoals, lying due south of the most southerly point of Africa, and extending easterly several degrees. That all these together form a chain, some of subaqueous, and some of superaqueous mountains; but all connected by their roots, is. 
Passage to perhaps, a conjecture less improbable, than that they the Indian
Ocean. abyss.

A settlement in Tristan d'Acunha is known to have been twice in the contemplation of adventurers; but not as yet to have been carried into execution. One had the project of rendering it a mart for the change of the light manufactures of Hindostan, suited to hot climes, for the silver of the Spanish settlements in South America; in the route between which places it is conveniently situated. The other plan meant it only as a suitable spot, for drying and preparing the furs of sea lions and seals, and for extracting the spermaceti of the white or long-nosed whale, and the whale-bone and oil of the black species. Whales of every kind were seen sporting hereabouts, particularly near the sctting of the sun; their enormous snouts rising sometimes above the waves, with a fountain spouting through an aperture in the skull. Sometimes their curved huge backs appeared like rocks in the middle of the ocean; and at other times they spread their tails like fans, and flapped them upon the surface of the water. The sword fish was likewise often seen; and these spectacles attracted the more notice, as little else occurred to diversify the scene. One vessel only, a Spanish brig, bound for the River de la Plata, was met between Rio and Tristan d'Acunlia.

On the fifth of January, 1793, the Lion crossed the 
meridian of London, at a distance, however, from that capital, of about ninety degrees of latitude, or six thousand two hundred and fifty-five miles nearer to the antarctic circle and southern pole. Sir Erasmus Gower observed, that "throughout the whole of this passage from Rio, " as well as farther on to the eastward, within four de"grees of the Cape of Good Hope, a small current set "constantly to the south-castward, which was proved "by solar and lunar observations, as well as by time"pieces. The ships did not approach that Cape nearer "than ninety leagues. For three degrees to the west" ward, and as many to the eastward of it, the current set "strongly to the westward. When opposite the Cape, "the ships steered more southerly, to get into the lati" tude of forty degrees south, so as to avoid the shoals " laid down in Mr. Dalrymple's charts, near the pa" rallel of thirty-eight degrees of southern latitude, and " extending in detached spots as far as twenty-five de"grees to the eastward of the Cape, as well as some "islands, said to be in the track of vessels bound to "Botany Bay, and little distant from the route to Ghina. "When within two hundred leagues of the islands of "St. Paul and Amsterdam, in the Indian ocean, the "ships returned to the latitude of thirty-eight degrees "forty minutes south, and continued in it, until those " islands came in sight, which was on the first of Fe"bruary, 1793. 
"In the passage from Tristan d'Acunha birds and Ind. Ocean.

"fish were seen in considerable numbers; whales al" most every day. In the high southern passage, nearly " forty-one degrees south latitude, the wind was between " the north-west and south-west, blowing strong; the " north-west wind producing fogs and rain, and the south" west wind clear and cold weather. Only one hard " gale was experienced the whole way, which was to " the eastward of Madagascar. It begun from the north" east, and ended at the south-west, blowing violently " in all directions, and occasioning an uncommonly " confused sea, so that the ship laboured much, and fre" quently rolled the gunwale, and part of the quarter" deck, under water, the masts forming an angle with " the horizon of about fifty degrees. There was also " a very great swell from the south-west, during the " whole passage, frequently without any apparent rea" son. As soon as the ships approached within about " thirty leagues to the westward of St. Paul and Amster" dam, a few seals and penguins were observed. The " sea became subject to tides or currents. One day's ob" servation gave twenty miles northing. On the even" ing of that day, a boat was sent to try what easting or " westing might be added to that northing; but reported, " on its return, that the current set due south, near a mile "an hour; which was confirmed by the observation " next day at noon." 
The mode of discovering a current, in a boat, is by sending it at some little distance from the ship, and then letting down a weight, often an iron pot, to a considerable depth (about two hundred fathoms) into the sea, which weight is thus found to answer the common purpose of an anchor, and keeps the boat from any progressive motion, currents being seldom found below ten fathoms. Any light body, thrown from the boat upon the surface of the sea, too thin and flat to receive any impulsion from the wind, must, if it moves, be moved only by a current, of which it is easy to observe the tendency, and measure the velocity.

The weather was now moderate and warm, suitable to the season, it being the month of January, which in this hemisphere is a part of summer. They who reside usually on the other side of the equator, must here dissociate some ideas, which had been hitherto connected in their minds. Thus, pleasantness and vigour must be transferred from May to December; and he who wishes to describe a chilling and uncomfortable aspect, must point directly to the south; while, on the contrary, the north revives his hopes of cheerfulness and warmth.

The islands of St. Paul and Amsterdam were perceived, lying in the same degree of longitude, the one about seventeen miles to the northward of the other. The Dutch navigators are said to have given the name of Amsterdam to the northern, and of St. Paul to the vol. $r$.

D d 
St. Paul and Amsterdam.

southern island ; and Captain Cook conforms to that appellation. Nost other English navigators, and particularly Messrs. Cox and Mortimer, reverse the names, calling the southernmost Amsterdam, and the other St. Paul. That which is to the south, and to which the Lion was now nearest, is high land, but considerably less so, than the island of Tristan d'Acunha. It appeared barren and destitute of trees ; smoke issued from many parts of it. As the ship approached the shore, two human figures were perceived to be moving on the land; they immediately made signals, waving a handkerchief tied to a pole, held by one of them in his hands, and both rumning along the cliff, as if endeavouring to keep up with the ship, as she moved forwards. It was conjectured, that those two persons might be the survivors of some shipwreck upon this desert coast; and a strong interest was excited in their favour, sufficient to determine upon stopping for them, even if no intention had previously been taken to pay a visit to the place; and it was deemed fortunate, that the Lion should be thus the means of relieving two men from the wretchedness they must feel, in so desolate a spot. The sequel of this work will, however, shew, that the Lion may have been probably the occasion of prolonging their detention in it. A boat was quickly dispatched for them, as well as to sound for anchorage. The boat had scarcely left the ship, when the two men were observed to descend 
from the cliff, towards the beach, and to prepare themselves as if to swim off to the boat. But this was prevented by the violence of the surge, which rendered the efforts of those men, as well as of the boat to approach to them, utterly ineffectual at that moment. There seemed, however, no danger in sailing along the island, except at the north-north-east end, from whence runs a low rocky reef, a part of which was conspicuous above water, and a part discoverable by sea weed, which grows upon, and rises from, the rocks; the whole extent being about half a mile.

When the ships came abreast of the eastern side of the island, a prodigious indenture in the land appear$\mathrm{ed}$, somewhat in the form of a funnel or inverted cone, at the bottom of which was perceived a cove, or large bason of water, communicating by a narrow and shallow opening with the sea. Opposite to this opening, the Lion anchored in twenty-five fathoms water, about a mile from shore, on a bottom of black sand and mud. Here, by a boat entering into the bason, it was perfectly easy to get on shore. As soon as the gentlemen from the Lion landed, they were received, not only by the two men they had discovered on the heights, but by three others who were their companions; and of whom their chief, or superintendant, who was an intelligent and communicative Frenchman, of the name of Perron, gave the following account. He said, that two, beside 
himself, were natives of France; the other two of England; the latter bred in the British navy, but afterwards become Americans, sailing usually out of Boston : that they came last from the Isle de France, and were left by the vessel to which they belonged, the joint property of Americans and Frenchmen, about five months since, upon this island, for the purpose of providing a cargo of tweinty-five thousand seal skins for the Canton market, which they hoped to complete in about ten months more, having already procured near eight thousand. The vessel had been fitted out at the Isle de France, in the Indian ocean; and was now gone to Nootka sound, on the north-west coast of America, with a view of bringing a quantity of sea-otter skins to China; and afterwards of calling for the cargo of seal skins at this place, to be carried to China likewise; proceeding thus, alternately, to Nootka and Amsterdam island, as long as the owners found their account in it.

The Chinese, it seems, have a particular art in dressing seal skins, depriving them of the long and coarser hair, leaving only the soft fur, or underdown, and, at the same time, rendering the skin or leather thin and pliant. The price of those skins at Canton differed from one to three clollars, or more, according to their quality, and the demand for them at the time. The trade was, probably, well worth following, to judge by the eagerness with which such an assemblage of persons had engaged 
in it. Perron had a share in the general adventure; but the people with him were paid in proportion to their expertness and diligence. Nothing but the prospect of considerable advantage could be supposed to induce any human beings to reside fifteen months together in a country so unpromising, and which their occupation in it renrlered so disgusting. They killed the seals as they found them basking in the sun, upon the stones every where along the shore, and round the large bason already mentioned. As the skins alone were their object, they left the carcasses on the ground to putrefy at leisure, strewed in such numbers as to render it difficult to avoid treading on them in walking along. A shocking spectacle was thus exhibited at every step, while the smell infected the atmosphere around. The people, thus employed, were, for the most part, remarkable for the squalor and filth of their persons, clothes, and dwelling. Yet none of them seemed anxious to catch at an opportunity of abandoning the place, before the business for which they came there was completed; and one of them, an Englishman, had been there for some time on a former adventure. The signals and apparent anxiety of two of these people, on the hills, which attracted so much the notice of the Lion, were occasioned by the novelty of the sight, at that time, to them, and the desire of inducing the ship to stop, without, perlaps, any distinct object of gratification. 
The seals, whose skins are thus an article of commerce, are found here in greater numbers in the summer than in the winter, when they generally keep in deep water, and under the weeds, which shelter them from the inclemency of the weather. In the summer months they come ashore, sometimes in droves of eight hundred or a thousand at a time, out of which about a hundred are destroyed, that number being as many as five men can skin and peg down to dry, in the course of a day. Little of the oil, which these animals might fumish, is collected, for want of casks to put it in; part of the best is boiled, and serves those people instead of butter. The seal of Amsterdam is the phoca ursina of Linnzus. The female weighs, usually, from seventy to one hundred and twenty pounds, and is from three to five feet in length; but the male is considerably larger. In general they are not shy: sometimes they plunge into the water instantly upon any one's approach; but, at other times, remain steadily on the rocks, bark, and rear themselves up in a menacing posture; but the blow of a stick upon the nose seemed sufficient to dispatch them. Most of those which come ashore are ficmales, in the proportion of more than thirty to one male. Whether, in those animals, nature has fixed on such an apparent disproportion between the two sexes, or whether. While the females have occasion to seck the shore, the males continue in the deep, has not hitherto been 
ascertained by any observations here. In the winter season great numbers of sea lions (phoce leonine), some Amsterdam. eighteen feet long, crawl out of the sea upon the causeway, making a prodigious lowling noise. Even the hollow mournful cry of the seals may be distinctly heard at the anchorage, which is a mile distant from the shore. It is thought that both seals and sea lions are somewhat less numerous here of late, since the place has been frequented by vessels for the purpose of getting their skins. Whales abound upon this coast in the winter season. In the summer they go into deeper water, and at a farther distance from the land.

The cove or bason, on the border of which the sealcatchers had erected a rude hut, was nearly in the form of an ellipse. On the side adjacent to the sea, its bank was low, composed of rounded stones, and divided in the middle by a shallow communication with the sca, of recent date, as Van Vlaming, a Dutch commander, who visited this place in 1697 , reports that there then was none, the intermediate causeway being, at that time, entire, and at least five feet high above the surface of the sea. Close to this causeway, interrupted now, the land on each side rises suddenly from the bason, and is continued round it to the height of, at least, seven hundred feet by trigonometrical admeasurement. At the same time it is so steep, as to form an angle with the horizon of about sixty-five degrees. The longest dia- 
Island meter across the surface of the water in this funnel Amsterdam.

was about one thousand one hundred yards, and the shortest eight hundred and fifty. The circumference, by the water's edge, was about three thousand yards, or a mile and three quarters nearly; the upper circumference of the funnel must, consequently, exceed two miles. In almost every part of the slanting sides of this funnel near the water's edge, and in the causeway dividing it from the sea, several springs of hot water were discovered. Fahrenheit's thermometer, which stood in the air at sixty-two degrees, on being immersed into one of those hot springs, ascended immediately to one hundred and ninety-six degrees. In another, it rose to two hundred and four; and in a third, on applying the bulb of the thermometer to a crevice out of which a snall stream issued, in less than a minute it rose to the boiling point. On various trials, in several springs, it was found that the general standard of lieat, was that of two hundred and twelve degrees, when the bulb of the thermometer was applied to the fissure from whence the water issued; and that if a kind of rescrvoir was formed romd the spring, the water in it would generally remain about the temperature of two hundred and four degrees. The bason abounded with tench, bream, and perch; and the same person, who, with a hook and line, had caught some of these fish in the cold water of the bason, might, with the same motion 
of his hand, let them drop into the hot adjoining spring, where, in fact, they were boiled, in the space of fifteen minutes, and fit for eating. A regale of this kind was mucli relished by some of the gentlemen from the Lion and Hindostan. It is easy to get at the boiling water in the causeway, by removing a few stones wherever a steam, arising from among them, denoted the lieat beneath. In some places large beds of mosses, known by the name of marchantia and lycopodium, were growing in great luxuriance; ont of which, as well, indeed, as from several fissures in the great funnel, issued a considerable quantity of smoke. A part of the moss being torn off, some thin hot mud was discovered underneath, in which the bulb of the thermometer being immersed, the quicksilver ascended, in the tube, to the boiling point. By applying the ear to the ground, a noise like that of bubbling water was distinctly heard. In many places veins of vitrified matter were observed to run perpendicularly from the water's edge, through substances that liad been burned, but not fused; and some of the rocks contained several beautiful pieces of zeolite.

Within two hundred yards of the canseway, and connected with it, is a curious insulated rock or cone, consisting of several horizontal layers of matter, some approaching to vitrification, others more distant from that state, but all indicating the operation of heat; and all the appearances seemed to confirm the assertion of vol. I. E e 
Island of Doctor Gillan that "the island of Amsterdam was the Amsterdam. "product of subterraneous fire; and bore evident marks "of volcanic eruption in every part of it. On the west " and south-west sides there are four small cones, regu"larly formed, with craters in their centres, in which "the lava and other volcanic substances, have every "appearance of recent formation. The heat continues "still so great, and such a quantity of elastic vapours " issues through numberless crevices, that there can be " no doubt of their having been, very lately, in a state "of eruption. In a thermometer, placed upon the sur"face, the quicksilver rose constantly to one hundred " and eighty degrees, and when sunk a little into the " ashes, it advanced to two hundred and twelve de"grees. It certainly would have risen still higher, but "the scale being graduated only to the point of boiling " water, and the length of the tube proportioned to that " extent, the thermometer was immediately withdrawn, " lest the increasing expansion of the quicksilver should " burst the glass. The ground was felt tremulous under "the feet; a stone thrown violently upon it returned " " hollow sound; and the heat was so intense, for a " considerable distance around, that the foot could not " be kept for a quarter of a minute in the same position, " without being scorched. But the great crater on the " castern side, now full of water, is by far the largest "here, or, perhaps, elsewhere, and is of an astonishing 
" size, considerably exceeding in diameter those of Etna " or Vesuvius. The quantity of matter to be thrown " up, which required so wide an orifice for its passage, " and the force with which such matter was impelled, " in order to overcome the resistance of the superin" cumbent earth and sea, must have been, indeed, pro" digious.

"This vast crater, according to the usual method of " computing the antiquity of volcanoes, must have been " formed at a very remote period. The lava all around " its sides is much decomposed, and has mouldered " into dust, which lies on the surface, in many parts, " to a considerable depth. The decomposition has sup" plied a rich soil for the long grass, growing on the " sides of the crater; and has even spread over most " parts of the island. The fibrous roots of the grass, " extending in all directions through the decomposed "lava, and volcanic ashes, and mixed in a decaying " state with the vegetable mold, produced from the an" nual putrefaction of the leaves and stalks, have formed " a layer of soil, several feet deep, all over the island. "But as it has nothing, except its own weight, to com"press it together, it is of a light spongy texture, with " very little cohesion, and, in many places, furrowed " and intersected by the summer rains, and the torrents " occasioned by the melting of the snow, which lies " upon it, in the winter, from three to four feet thick. 
" in all those places where the subterraneous heat is not " great enough to prevent its accumulation. In some " parts these furrows and cavities are deeper than the "level of the common channel. Hence they serve the " purpose of small natural reservoirs. The water flows " into them from all the neighbouring ground; and as " their sides are shaded, and almost covered over by the "leaves of the long grass, growing from their edges in "opposite directions, the rays of the sun are excluded, "and very little is lost by evaporation. These reser" voirs, however, are very small, and but few in num" ber; the largest could not contain more than three or " four hogsheads of water; and there is none else to be "found, except in the springs on the sides of the large "crater.

"The soil every where being light and spongy, and "full of holes, formed in it by sea birds for nests, is "very troublesome to walk upon; the foot breaks "through the surface, and sinks deep at every step; a " circumstance which renders the journey across the " island uncommonly fatiguing, although it be scarcely " three miles from the edge of the great crater to the op" posite west side. There is one place, near the centre " of the island, extending about two hundred yards in " length, and somewhat less in breadth, where particu"lar caution is necessary in walking over it. From this "spot a hot fiesh spring is supposed to derive its source, 
"finding its way through the interstices of the lava to " the great crater, and bursting out a little above the

" water covering its bottom. The heat in this upper "spot is too great to admit of vegetation. The surface " is covered with a kind of mud or paste, formed from " the ashes, moistened by steam constantly rising from "below. When the mud is removed, the vapour issues "forth with violence, and in some parts copionsly. "This mud is so hot, that a gentleman who, inadver" tently, stepped into it, had his foot severely scalded "by it. The same causes, which have prevented vege"tation on this spot, have had the same effect on the "four cones recently thrown up. Their surfaces are " covered with ashes only; nor is there the least appear" ance even of moss on the surrounding lava, for the "production of which there does not appear to have " elapsed a sufficient length of time since the cones " were formed; but this is not the case with the lava " of the great primary crater; for in those parts of it " where the edges are more perpendicular, and where, " consequently, the mouldering decomposed earth, hav" ing no basis to support it, slides down the sides of the " rock, pretty long moss was generally found growing "upon it. All the springs or reservoirs of hot water, " except one only, were brackish. One spring derives " its source from the high ground, and ridges of the " crater. The water in it, instead of boiling upwards 


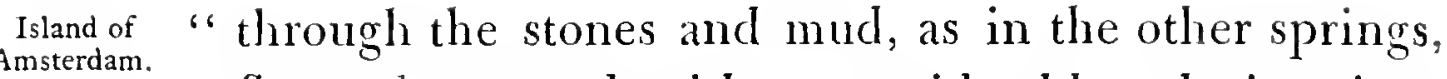
Amsterdam. "flows downward with a considerable velocity, in a "small collected stream. Its temperature has been " found not to exceed one hundred and twelve degrees. "The hand could be easily kept in it for a considerable " time. It is a pretty strong chalybeate. The sides of " the rock whence it issues, and of the cavity into which " it falls, are incrusted with ochre deposited from it. "This is the water used by the seamen dwelling upon " the island. They feel no inconvenience from its use; " and habit has reconciled them to its taste. When the "great crater is viewed from the high ground, it appears "to have been originally a perfect circle; but to have " been encroached upon by the sea on the eastern side, " where the flood tide strikes violently. The rocks of " lava, which formed the edge of the crater on that side, " have fallen down. The depth of the water in the " crater is about one hundred and seventy feet, render" ing the whole height of the crater, from the bottom " to its upper ridge, nearly, if not quite, nine hundred "feet. The lofty rocks, forming this ridge, are the " highest parts of the island, which seem to have been " originally produced by the melted lava, flowing down "on all sides from hence. Thus there is a gradual "slope from the edges of the crater to the sea: and the " lava, tho very irregular, and lying in mixed ruin " and confusion immediately around the crater, assumes 
"a more uniform appearance at some distance, layer "resting regularly upon layer, with a gradual decliIsland of
Amsterdam. "vity the whole way down to the sea. This dispo" sition of the layers is particularly observable in the " west sicle, where they happen to terminate in an abrupt " precipice. The eruptions that took place, at different " periods, appear here distinctly marked by the different "layers that are found with regular divisions between " them, the glassy lava being undermost; the compact, " next; the cellular lava next above; over it the volcanic " ashes and lighter substances, and a layer of vegetable " mold covering the whole."

The island appears, indeed, in such a state of volcanic inflammation, that from the ships' decks at night were observed, upon the heights of the island, several fires, issuing out of the crevices of the earth, more considerable, but in other respects resembling somewhat the nightly flames at Pietra Mala, in the mountains between Florence and Bologna, or those near Bradley in Lancashire, occasioned by some of the coal pits having taken fire. In the day, nothing more than smoke could be perceived.

The island of Amsterdam lies in thirty-eight degrees forty-two minutes south latitude, and in seventy-six degrees fifty-four minutes longitude east of Greenwich. The variation of the compass in the great crater was nineteen degrees fifty minutes westward of the north 
Island of
Ainsterdam. Amsterdam. north to south is upwards of four miles, its breadth from east to west about two miles and a half, and its circumference eleven miles, comprehending a surface of about eight square miles, or five thousand one hundred and twenty acres, almost the whole of which is covered with a fertile soil. The island is inaccessible except on the east side, where the great crater forms a harbour, the entrance to which is deepening annually, and might, by the aid of art, be made fit for the passage of large ships. The tides run in and out at the rate of three miles an hour, and rise perpendicularly eight or nine feet on the full and change of the moon. Their direction is south-east by south, and north-east by north. A northerly wind makes the highest tide. The water is eight or ten fathoms deep almost close to the edge of the crater. The Englishman who had been, for the second time, upon the island, gave a very unfavourable account of the weather during the winter months. In the summer months it was acknowledged to be very fine, and easterly winds uncommon; but the winter was always boisterous, with hail and snow, and a great swell produced by winds blowing constantly from the north-west or south-west quarters. In those times, he said, a whirlwind was sometimes scen to swecp off the surface of the water in the crater, and to r.dise it in vast sheets to the very top of the surrounding 
sides, already mentioned to be found by admeasurement no less than seven hundred feet in perpendicular height.

The small vessel, in which the present inhabitants of the island were brought to it in the preceding September, remained either at anchor or in the offing for eight weeks; during the whole of which time, a boat was able to land only twice; and, in consequence, they were left with such a scanty supply of provisions, that they must have perished, had not the island furnished them with plenty of fish and fowl. They stood most in need of vegetable food; but beside what was given to them from the Lion and Hindostan, the gardeners planted potatoes and other vegetables round their hut, which may prove a seasonable relief to them, or to their successors upon the island: a circumstance the more desireable from its lying in the track of ships for China, as well as of those bound, by the onter passage, to the eastern side of Hindostan.

The sea supplies this island with excellent fish, particularly a kind of cod, which was equally relished whether fresh or salted. Cray fish was in such abundance on the bar across the entrance into the crater, that at low water they might be taken by the hand. At the anchorage of the ships the people took them by letting down into the sea baskets, in which were baits of sharks' flesh. In a few minutes, the baskets being drawn up, were found half filled with cray fish. Hooks and lines speedily pro- 
Island of cured a change of diet for a week. This circumstance was Amsterdam. mon size, abounded in the same place, which are known to be so voracious, and such enemies to all other fish. One shark was caught measuring eleven feet in length, and near five in circumference. In his mav was found a penguin entire, an animal classed by all naturalists among birds, but certainly partaking much of the fishy tribe, not only by its frequent residence in the water, which renders it a prey to sharks, but by its scale-like feathers, and its fin-like wings. The species here found in vast abundance, often basking and standing erect on the rocks, in company with the seals, is distinguished by Linnaus by the name of chrysocoma, having large yellow feathers, forming two semicircles over the eyes, like eyebrows.

Of all the birds which frequent this spot, so extraordinary in its origin, formation, and appearance, not one is common to the same degree of latitude, in the northern hemisphere. Of the larger kind were several species of the albatross; on examining one of which, distinguished by the name of exulans, it was found that instead of having only the rudiments of a tongue, as supposed by naturalists, it had one equalling half the length of the bitl. The yellow-billed albatross is not quite so large as the former; but the brown albatross is of a greatcrbelk. Thespecimen of the latter, carried on board 
the Lion, weighed sixteen pounds, the expansion of its wings was nine feet, thie plumage particularly thick upon the breast. The albatross finds a difficulty in raising itself on a sudden into the air; but is obliged to start from a precipice, or to run a considerable way upon the ground, in order to acquire an impetus or quantity of motion sufficient to lift him on the wing. When in the water he makes several efforts before he can rise out of it. Another large bird is likewise common here, called the great black petrel, and is the procellaria equinoctialis of Linnæus; it is the determined enemy of the albatross, whom it attacks always, whenever it finds him on the wing, but quits as soon as the albatross takes to the water, which is his constant refuge in such rencounters. This petrel is a fierce and voracious animal; tho one of them soon grew tame on board the Lion, eating quietly the garbage and offals set before it; and seemed to take great delight in bathing in a tub of sea water; and it was, therefore, often indulged in that luxury. This bird is a still more fatal enemy to the blue petrel of Amsterdam, or procellaria forsteri, than to the albatross. It devours only the heart and liver of the former, leaving the rest untouched. Hundreds of them, thus eviscerated, were found lying upon the earth throughout the island. They hide themselves under ground in the day-time, in order to escape, if possible, from their destroyer. Sometimes, indeed, in that situation, they make a noise, 
Island of by which they are discovered. At night they come
Amsterdam $\stackrel{\text { Amsterdam }}{=}$ abroad, and thence are termed night birds by the people at Amsterdam; but bcing fond of Hocking to any light, they fall into another snare laid for them by the seal catchers, who kindle torches for that purpose, and kill multitudes of them. They constitute indeed the principal food of these people, who think it very good. This blue petrel is about the sizc of a pigeon. Another petrel, of a much smaller size and darker colour, frequents this island likewise. It is often observed upon the ocean in bad weather, and is therefore called the stormy petrel; or in the sailors' language. allusive to some witch's story, now forgotten, Mother Cary's chicken. The prettiest of the feathered tribe, inhabiting or visiting Amsterdam, was the silver bird, or slemu limulo, about the size of a large swallow or swift, with a forked or swallow tail. The bill and legs are of a bright crimson colour, the belly white, the back and wings bluish ash-colour. This bird subsists chichly on small fish, which it picks up as they are swimming near the surface of the water. Mr. Maxwell shot a sifver bird flying; and as it fell, a fish of about three inches long was found held crosswise by its bill. These birds range about in very considerable numbers, and with no apprehension of danger. Whenever a young one was taken, the others kept lluttering about the captor for a considerable time, making all the noise they could, and seening to theaten as il they meant to 
strike or dart upon his head, in order to frighten and force him to give up his prize.

In the tour which some of the gentlemen from the Lion made of this small but singular island, they were accompanied by Perron, the chief of the seafaring men then resident upon it, who very readily offered to conduct them, as he was acquainted with the path leading up the side of the hill or lumnel, by which alone it was possible to ascend it; and even there not without labour, and some risk. Above, there was found a level, extending about a mile; afterwards, a gradual declivity towards the sea, to within fifty yards, where the ground ends in a precipice, inaccessible from below, except in one place, to which a path communicates with the high land. By this the seal catchers are enabled to pass to the shore, when the direction of the wind induces the seals to seek protection from the roughness of the water on the opposite side. When the party returned to the eastward of the island where the ships had been at anchor, they were perceived to be preparing for departure; and the gentlemen, who felt themselves indebted to Perron for his complaisance and attention to them on their little tour, as well as for his ready communication of whatever he had observed during his stay upon the island, had the mortification to find that he had, for his reward, been despoiled, during his absence with them, of no inconsiderable proportion of the skins, which must have cost 
Island of so much, to a man of his decent manners and disposition, $\stackrel{\text { Amsterdam. }}{\longrightarrow}$ to collect. While he was away from the hut where they were kept, some persons from the ships, suspected to be above the rank of common seamen, brought spirituous liquors ashore, which was a temptation too strong for the other seal-catchers to resist. They first began to bargain upon reasonable conditions, except offering a property not their own; but when once they had tasted the rum in sufficient quantity to affect their understanding, they lessened the heap of skins with a profusion which knew no bounds; and Perron had to regret his good nature to strangers, which gave the opportunity of thus injuring him, and to lament the arrival of English ships at the place of his abode. Sir Erasmus Gower, who felt much indignation when he heard the story, ordered a general search to be made for the skins thus unwarrantably acquired. Some were found; and it was intended to leave them at Ganton; for the Lion was already under sail from Amsterdam before he could know the fact. How subsequent events rendered this determination vain, will hereafter be related to the reader.

St. Paul's, or the island lying in sight, and to the northward of Amsterdam, differed in appearance materially from the latter. It presented no very high land, or any rising in a conic form. It was overspread with shrubs and trees of a middling size. It was said to 
abound with fresh water; but had no good anchorage near it, or any place of easy landing. The ships lost sight of both those islands, on the evening of the second of February, 1793.

In the folio volume of plates, belonging to this work, will be found a view and plan of the island of Amsterdam, and of the great crater on the eastern side of it. 


\section{CHAPTER VII.}

ENTRANCE INTO THE STRAITS OF SUNDA. VISIT TO BATAVIA AND BANTAI, IN THE ISLAND OF JAVA. VIEIV OF THE SOUTHERN EXTREMITY OF TIIE ISLAND OF SUMATRA. PASSAGE THROUGH THE STRAITS OF BANKA TO PULO CONDORE.

After having sailed in high southern latitudes during as much of the year 1793 as had hitherto been spent, and traversed an ocean of more extent than is found continuous within the boundaries of Europe, but in a part where there was no likelihood of meeting any vessels, the Embassador and other passengers of the Lion and Hindostan bcgan, at length, to indulge the hope of getting soon into a track, where they might obtain intelligence, through the homeward bound ships from China, of the impression which the notification of the Embassy had made there. Those ships generally lind it necessary to deviate to the southward of the direct route, in order to get into latitudes where the winds are most livonrable for at passage home. The Lion and Hindostin were, indecd, still considerably to the southward of such a route; but in making an oblique comse to the north-cast, in order to get into the Strats of 
Sunda, there was a probability that they would meet passage to the homeward bound ships, sailing in the oppositc diSunda. rection, from the Straits' mouth. The wind did not always favour the intention of the former; and, sometimes, blew from the very point towards which they wished to steer. It soon, however, changed, not indeed entirely to the opposite point; but to that, from whence it came, in the nautical phrase, upon the quarter, in which situation, as the wind could be brought to act upon many more sails, than if it struck merely upon the stern in the exact direction of the vessel's course, it produces a more considerable effect; and the Lion's motion was so accelerated as to go no less than two hundred and thirty-nine miles on the day she returned within the tropics, being more than had been before accomplished, in an equal time, during the whole voyage.

While the breeze was fresh, the weather, notwithstanding the sun's vertical heat, was always pleasant. The tropic birds, remarkable for their very high flight, and their long tail feathers, began to appear again; and the porpoises to play upon the waters; while the flying fish were seen in numbers escaping only from their finny pursuers, to become a prey to the winged tribe, that was watching to dart upon them as soon as they rose above the water. Several water-spouts were now observed; some resembling jet d'eaus, almost reaching to the lowered clouds, some not unlike the blowing of a whale.

vOL. I.

$\mathrm{G} g$ 
Passage to the Straits of Sunda.

The ships spread more than usual from each other, in order to embrace a greater extent of the horizon, and thereby have a better chance of espying any vessel which might be steering from the Straits of Sunda towards Europe. Most persons in the Lion and Hindostan prepared for such a meeting, which could be only of short continuance, by writing letters to send to their connections and friends at home; an occupation which recalled, for a moment, their distant cares, and renewed all their sensations of friendship and affection. In the ardour of searching for other ships, the Lion and Hindostan, who had kept so constantly together, in passing through upwards of a hundred degrees of latitude, and still more of longitude, separated, by some accident, now for the first time. Each pursued his route for North Island, being the accustomed rendezvous in the Straits of Sunda.

The disadvantage of a long continuance at sea became now apparent, from the scorbutic symptoms which began to affect several of both the crews, notwithstanding the measures taken for the preservation of their health, which have been already mentioned; to which may be added the use of anti-scorbutics, such as the mixture of sour-crout, or pickled cablsage, in their food; and the occasional distribution amongst them of the essence of malt. They were much gratified by the indulgence allowed them of tobacco. It was hoped that the air of 
land, to which they were now approaching, and the use of fresh vegetables to be found there, might prove still more effectual remedies. The officers of the Lion expected when they got into the twentieth degree of south latitude, and in the hundredth degree of east longitude, or upwards, from Greenwich, that the appearance of weeds, land birds, or of fish frequenting shores, would have indicated the neighbourhood of land, as Cloat's island and the Tryal rocks are laid down thereabouts in several charts; but no such traces were perceived until they were within seven degrees of the latitude of the Line, and somewhat more than one hundred and three degrees east longitude, when they saw a very small island, which they supposed to be that which is called Clapp's island, not above seven or eight miles in circumference; but it is high enough to be seen, in clear weather, at the distance of as many leagues. The next day, being the twenty-fifth of February, 1793 , they came in sight of the most westerly point of the island of Java, called Java head; and, soon afterwards, saw Prince's island at the entrance of the Straits of Sunda.

The great island of Sumatra by its south-east, and that of Java by its north-west, extremity, approaching to each other, form those straits between them, which are interspersed with a number of small isles; the whole displaying a scenery, inferior incleed in grandeur to that of the lofty range of mountains round the harbour of 
Straits of Rio de Janeiro, but scarcely to be exceeded in the soft-

Sunda. ness, richness, and gaiety of its appearance. The two great islands, first mentioned, which are low, and in some places marshy, near the shore, rise afterwards in a gradual slope towards the interior of the country, admitting in their ascent every variety of situation, and all the different tints of verdure. Of the smaller islands, a few have steep and naked sides, such as one in the middle of the strait, which the English navigators have distinguished, on that account, by the name of Thwartthe-way, and two very small round ones called, from their figures, the Cap and Button; but most of the others are entirely level, founded upon beds of coral, and covered with trees. Some of these islands are surrounded with a white sandy beach, visited frequently by turtle; but most of them are adorned with thick shrubbery to the water's edge, the roots being washed by the sea, or the branches dipping into it; and on the outside are shoals, in which a multitude of little aquatic animals are busied in framing calcareous habitations for their residence and protection. Those fabrics gradually cmerge above the surface of the water, and, at length, by the adventitious adhesion of vegetable matter, giving birth to plants and trees, become new islands, or add to the size of those already produced by the same means. It is impossible not to be struck with the diversified operations of nature for obtaining the same end, whether 
employed in originally fixing the granite foundation of the Brazils, or in throwing up, by some sudden and subsequent convulsion, the island of Amsterdam, or in continuing to this hour, through the means of animated beings, the formation of new lands in the Straits of Sunda.

One of these coralline productions is North Island, where the Lion found the Hindostan at anchor. The latter met, near the mouth of the Straits, with one of the East India Company's ships returning home from China. She had brought dispatches from the Company's Commissioners at Canton to the Embassador, which, after the ship had waited ten days for his Excellency at Batavia, were left there for him. On the Lion's proceeding, together with the Hindostan, to that place, the voyage was found to resemble a short trip of pleasure. The sea was perfectly smooth; and its surface studded with innumerable clusters of coral islands. The substance of which they are composed is in a hard state, and similar to rock; but in various places considerable quantities of zoophytes were dragged from the sea, some of a fleshy, and some of a leathery texture. Of the corals there were vast masses, and of various species, the madrepora, cellipora, and tubipora, of different shapes, flat, round, and branched; and, as to colour, brown, white, and blue; and all these colours not unfrequently in the same specimen; but none red, except the tubularia musica. 
Of the prodigious variety of aquatic animals, independently of those which produce the coral islands, a large proportion is doomed to move only along the bottom of the sea, of which the most numerous here were the sea urchin, star fish, and the holothuria. Others are still more confined in their movements than the common oyster, whose shells are not immoveably fixed to a particular spot, but are sometimes transported from one bank to another, by the impulse of tides or currents, or other motion of the waters near them; whereas there are animals of a similar kind, which, beside being inclosed in a bivalve shell, are imbedded, with the shell itself, in a large mass of calcareous rock, having only a sufficient play for the hinges, that the valves may open, and shut upon whatever prey the passing waves casually waft towards them. These are some, among the many instances, of the regular gradations of animal life, from rapid motion and exquisite sensibility, to the borders of mere vegetable irritability; where those two kingdoms of nature seem to meet, and to be confounded together. The coral rocks above the surface, on which vegetation flourished, were many of them so small, as to contain each only a single stem, like a vessel's mast, upon it; the whole of them presenting, to a distant view, the appearance of several fleets of shipping. Within one of these clusters, distinguished, from its number, by the name of the Thousand Islands, the Lion and Hindostan anchored, 
during the night. The sky was clear, and the stars Batavia. shone with singular lustre. Those of the first and second magnitude, might be observed, distinctly, rising from the horizon, or descending beneath it; and their amplitudes, or distances from the east or west points, might have been taken as accurately as that of the sun or moon. The southern constellations of the centaur, cross, and argo, seemed to form a brighter portion of the firmament than any which the eye can reach from high northern latitudes.

The ships arrived on the sixth of March in Batavia road, which lies in six degrees ten minutes south latitude, and in one hundred and six degrees fifty-one minutes eastern longitude from Greenwich; the variation of the compass about half a degree to the westward of the pole. In this passage to Batavia there are several shoals. Beacons are fixed on some to point out the danger; others are not even noticed in the marine charts made by the Dutch, at an early period of their settlement on this coast; and are supposed to be collections of coral, formerly lying deeper, but which, by continual accretion, have risen nearer to the surface. That there is some increase of land, from other causes, at the entrance of Batavia, is evident from an inspection of the plan of that city, taken about a century and a half ago, of which a copy is inserted in Ogilby's account of the Dutch embassy to China. According to this plan the 
Batavia. principal fort or citadel of Batavia was situated close to the beach, and a double row of piles driven a considerable way, perhaps a mile, out into the shallow sea, to denote the safest passage to be between them; whereas now there is land, and even a row of houses on one side, to the very extremity of those piles. This increase was, however, greatly assisted, if not chiefly effected, by human industry, exerted in banking up the earth washed from the mountains by the river, which is much more steep and rapid at its origin than where it empties itself into the sea.

A circular range of islands protects the road of Batavia from any heavy swell, and renders it a safe place for ships to anchor in; and it is large enough to contain all those that double the Cape of Good Hope. The great number of Dutch vessels lying before the city was alone sufficient to announce it to be their principal place of trade, as well as the seat of their chief government in Asia. The Chinese juncks, also, so ill calculated for long voyages, which were at anchor in the road, already indicated the vicinity of that empire. Few of the buildings of the city of Batavia were perceptible from the road, except the dome of the great church; the rest being chiefly hidden, as well as shaded, by the large leaves of lofty palms, and other high and spreading trees.

The Embassador, after having been complimented on board, on the part of the Dutch government, was received 
on shore with distinguished honours; tho his mission Batavia. had created there strong alarms. No accomnt, it seems, had reached Batavia of the liberal commmication, and proffer of service, made to the States General by the administration of Great Britain, upon the occasion of the Embassy. When these were now amounced by the Embassador to the Governor and Council, the secret apprehensions that had been entertained by them were frankly acknowledged; as well as the intention of their agents at Canton to join in counteracting his Excellency there as much as lay in their power. The government of Batavia was made sensible that there was room enough for the commerce of both nations; and the Council immediately determined to send instructions to Canton for uniting with, instead of opposing, the efforts of the Embassador, from whence it was to be hoped that every European nation, trading to Ghina, would be benefited in the end. The dispatches his Excellency received here from the Commissioners of the English East India Company at Canton, augured favourably for his honourable reception at the court of Pekin. The Commissioners mentioned that " having applied to two of the "principal Chinese merchants to solicit an audience "from the Fouyen or Governor of Canton, in the ab"sence of the Viceroy of the province, in order to " deliver a letter to him from the Chaimman of the Court " of Directors of the East India Company; those merVOL. I. 
Eatrvia. "chants readily guessed that the letter related to the "Embassy, of which the rumour had spread amongst "them; and expressed some degree of apprehension "lest the measure might, in its consequences, affect the "trade, property, or personal security of the native "merchants of Canton; but that the Commissioners " assured them that it would rather be productive of " good than of ill consequences to all the trading part " of the community; that the motives of the Embassy "were anxiously enquired into, on the part of the "officers of government, as a preliminary step to the "audience required by the Commissioners, who de"clared that nothing further was intended than to " effect a stricter friendship between the courts of Lon"don and Pekin, and an increase of that intercourse, "which had been carried on for so many years, to " the advantage of both nations; that this explanation "was probably satisfactory, as the day for their recep"tion was fixed at an earlier period than could have "been expected, from the procrastinating and super"stitious temper of the Chinese; that a message was " afterwards, however, sent by the Governor to learn " the rank and situation of the person from whom the "letter came; and whether he was a servant of the "King, and held an office under his seal; that in "answer it was said, that the letter, tho not written by "an immediate servant of the King, was sent to the 
"Viceroy with his Majesty's knowledge, to announce Baravia. "the approach of his Embassador to Pekin; that in " consequence, however, of the letter not having been " written by an immediate officer of the crown, nor to " be delivered by persons in its service, but in that only " of the Company, objections arose to the intended form " of their reception; but as any contest about ceremony "might have been followed by a refusal to receive the "letter, till an answer could be obtained from Pekin, " which was a subterfuge that the Hoppo or mandarine " more immediately connected with Europeans, and " interested in preventing representations of any kind " from reaching Pekin, betrayed a disposition of urging " to the Fouyen, it was determined to deliver the letter " in any manner that might be prescribed. It became " necessary, likewise, to communicate its contents; and " it was with no small trouble and difficulty that the Chi" nese merchants, who were the only interpreters, could " be brought to comprehend the particulars of the letter, " and the real object of the Embassy. The want of a "competent linguist, and the necessity of encourage"ment to attain the Chinese language, under the ob"stacles to be encountered in such a pursuit, were, "perhaps, never so apparent as on this occasion; and "the English commissioners could not but lament the " want of an interpreter of their own nation, capable of " conceiving and rendering the spirit of the letter, and 
Eatavia. "of carrying on with advantage a conference both de" licate and important. That it ended, however, in a " promise that the letter should be forwarded to the Em"peror; and the result made known to them through "the Chinese merchants. That accordingly, some time " afterwards, his Imperial Majesty's pleasure was pub"lished upon the subject, in an edict declaring his sa" tisfaction at the intended Embassy; and giving orders " that pilots should be properly stationed to conduct the " ships, in which the Embassador and the presents from " the King of Great Britain were expected, into the port " of Tien-sing, or any other they might think more " convenient, or prefer." The Commissioners added, that "the impression looked for from the Embassy had " already taken place on the officers of government "at Ganton. Less interuption to foreign trade, and a "more ready attention to the representations of the "Commissioners, were very apparent; and the Hoppo " was already said to have in contemplation to abolish "the extravagant charges at Macao, by which means " one of the principal impositions upon foreigners would “ be suppressed.”

The communication of these dispatches to the Batavian government, which felt now a common interest in the present Embassy, occasioned additional festivities to those with which it was intended to celebrate the amniversary of the birth of the Prince of Orange, Stadt- 
holder of the United Provinces. His high office and commanding influence, particularly in the affairs of the East India Company of that country, placed him upon the level of a sovereign; and his serene highness was much more the object of respect and apparent attachment than the States General, tho nominally his superiors. The mingled taste and united luxuries of a Dutch and Eastern entertainment, to which the Embassador and his suite were all invited, were displayed upon the occasion. It was given at the house of the Governor-general, a little way out of town; the road to it led through an avenue of trees, bordered by canals, near which, on one side, the humours of a Flemish fair were exhibited, for the amusement of the people; and, on the other, upon such a large cart as is supposed to be the original scene of dramatic performances, appeared several Chinese actors, whom some of the Governor's new guests would have preferred stopping to observe, rather than to partake of the sumptuous banquet within doors. This banquet was preceded by a ball, and accompanied by illuminations and fire-works in the garden, which seemed multiplied by reflection from the several pieces of water that covered a great proportion of the ground; nor did the company separate till near the morning.

Notwithstanding these occasional scenes of merriment, implying the enjoyment of health and vigour, the grreatest number of the Dutch settlers in Batavia, such as 
Baravia. were commonly seen at their doors, or met with in the streets, appeared wan, weak, and languid, and as if labouring with the " disease of death." Their place of residence, indeed, is situated in the midst of swamps and stagnated pools, from whence they are every morning saluted with " a congregation of foul and pestilential "vapours," whenever the sea breeze sets in, and blows over this morass. The meridian sun raises from the shallow and muddy canals, with which the town is intersected, deleterious miasmata into the air; and the trees with which the quays and streets are crowded, emit noxious exhalations in the night. The sudden transition likewise from a cold northern region to the middle of the torrid zone, without the adoption of the habits requisite in the latter, must render the human frame more liable to be affected by any causes of disease.

Doctor Gillan understood that " there were but few " examples of strangers remaining in Batavia long with" out being attacked by fever, which is the general "denomination, in that place, for illness of every $k$ ind. "Europeans, soon after their arrival, first become lan"guid and feeble; and in a ferv weeks, sometimes in a " lew ditys, are taken ill. The disorder, at first, is com" monly a tertian ague, which, after two or three pa" roxysms, becomes a double tertian, and then a conti" nued remittent, that frequently carries off the patient " in a short time. Many fall victims to the second or 
" third fit; but in these cases a constant delirium, and Batavia. " a great determination of the blood to the brain accom" pany the other symptoms. In some it begins in a "quotidian form, with regular intermissions for a day "or two; and then becomes a continued remittent, at" tended with the same fatal consequences as the former. "The Peruvian bark was seldom prescribed in any "stage of the disease; or it was given in such small "quantities as to be productive of little benefit. No " change was made in the diet or regimen of the patient; " and the chief, or rather the sole medicine administered, " was a solution of camphor in spirit of wine, of which " a table-spoonful was taken, occasionally, in a glass of "water. The practitioners of physic in Batavia, where " the presence of the most skilful certainly was neces"sary, not having had the advantages of a medical edu"cation, were satisfied, as to theory, with considering " the nature of the fever as being to rot and corrupt the " human frame; and, as to practice, that camphor being " the most powerful antisceptic known, it was proper "to trust to it, by a rule more simple even than Mo" liere's, and to exhibit it in every variety and period " of the complaint. The intermittent fever does not, " however, prove always fatal; but continues, in some " instances, even for many years; and the patient be" comes so familiarized to it, as scarcely to think it a " disease; and in the intervals of its attack, attends to 
Batavia. "his affairs, and mixes in society. A gentleman, in " that predicament, conversing upon the nature of the " climate, observed that, in fact, it was fatal to vast " numbers of Europeans who came to settle there; that " he lost many of his friends every year; but for his "part, he enjoyed excellent health. Soon after, he "called for a napkin to wipe his forehead, adding, that "this was his fever day; he had a shocking fit that "morning, and still continued to perspire profusely. "Upon being reminded of his late assertion of being "always healthy, he replied he was so, with exception " of those fits, which did not prevent him from being "generally very well; that he was conscious they " would destroy him by degrees, were he to remain in "the country long; but that he hoped his affairs would "enable him to. lave it before that event was likely to "take place. Those fits are always followed by ob"structions, and hard swellings in the bowels. Their " increase is regular and gradual; and he that is atten" tive to their progress, may almost calculate how long "he has yet to live. It is supposed that of the Europeans, "of all classes, who come to settle in Batavia, not, "always, half the number survives the vear. The place "resembles, in that respect, a field of battle, or a town "besieged. The frequency of deaths renders familiar "the mention of them, and little signs are shewn of "emotion or surprise on hearing that the companion 
" of yesterday, is to-diay no more. It is probable, female "Europeans suffer less at Batavia than the men. The "former seldom expose themselves to the heat of the "sun, make frequent use of the cold bath, and live " more temperately than the other sex."

Of the fatal effects of the climate upon both sexes, however, a strong proof was given by a lady there, who mentioned, that out of eleven persons of her family who had come to Batavial only ten months before, her father, brother-in-law, and six sisters, had al ready paid the debt of nature. That there are constitutions, however, so formed, as to be little affected by causes fatal to many others, appeared in particular instances; such as that of the gentleman who was governor-general when the Lion was at Batavia. He had been upwards of forty years in the country, was a man of great application to business, and took no uncommon precantion for the preservation of his health: such also was one of the counsellors of the Indies, as the members of this government are entifled, at whose house the Embassador, and two persons of his suite, resided, and were entertained with equal hospitality and splendour while they remained ashore. This gentleman's house was generously open to all strangers; nor did he set them the example of abstemiousness in his own person. Both he and the governor were not only exempt from sickness, but even from any kind of languor, so frequently expeyol. I.

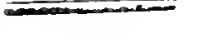


Batavia. rienced by others in every part of the torrid zone, as well as at Batavia. There were other gentlemen of habits less robust, but whose active minds were not affected by the climate. Even learning was cultivated in the midst of more profitable occupations. An observatory had been erected here, which, indeed, was now neglected; but an academy of sciences and literature still subsisted. Among other marks of attention paid to the Embassador, diplomas were presented to him and to one of his suite, as members of the academy, together with sets of the volumes hitherto published by it. One of the members of the council, who had formerly resided as chief of the Dutch commerce at Japan, had in contemplation to publish a description of that country, for which his situation and ingenuity enabled him to collect very interesting materials.

The Embassador's host had a very curious collection in the several departments of natural history. He made presents to his guests of several specimens. Among them was a beautilul pheasant, which, on bcing sent to England, and shewn to a gentleman of acknowledged eminence in all branches of zoology, Doctor Shaw of the British Muscum, he was of opinion, that "this " superb pheasant was a bird which, from every exa" mination of the writers on omithological subjects, " appeared to be yet undescribed. None of the spe" cies mentioned by Linnicus, and Mr. Latham, could 
" in any degree, be supposed to relate to this. The Batavia.

"species to which it seemed to be most nearly allied, " in point of general habit or appearance, was the "phasianus curvirostris, or Impeyan pheasant; an East "Indian bird, described and figured both in Mr. La"tham's Ornithology, and in the Museum Leverianum. "From that bird, however, it differs very considerably; " as a collation of those figures, with the present, would " effectually evince. The tail of the latter being in at " mutilated state, it was scarce possible to determine, " with absolute precision, whether it should be referred " to that subdivision of pheasants, which contains those " with long or cuneiform tails, or those with rounded " ones, as in the Impeyan pheasant; for which reason, " the representation in the plate, No. 13, (engraved for " the present work,) was so conducted as purposely to " leave this particular undetermined. The general co"lour of this most elegant bird was black, with a gloss " of blue, or what, in the linguage of natural history, " may be termed chalybean black, or black accom"panied by a steel-blue lustre. The lower part of the " back was of a peculiarly rich colour, which, according " to the different directions of the light, appeared either " of a deep ferruginous, or of the brightest fiery orange" red. This beautiful colour passed in the manner of a " broad zone, round the whole body; but on the ab"domen, was of a much more obscure appearance than 
Batavia. "on the back, as well as somewhat broken or irregular, " especially on the sides. The throat was furnished " with a large, and somewhat angular, pair of wattles, " uniting with the bare spaces on the cheeks. The "feathers on the top of the head, which was of a " lengthened form, ran a little backward, so as to give " the appearance of an indistinct occipital crest. 'The "beak was remarkable for a more lengthened and "curved aspect, than in any other bird of this genus, " except the Impeyan pheasant. The feathers on the "neck, back, and breast, were rounded, and of the . same shell-like or scaly habit, as those of the turkey. " The legs very stout, and were armed with a pair of " extremely strong, large, and sharp spurs. Both legs " and beak were of a pale colour. Whether this bird be " really new or not to the ornithologists of Europe, it " may at least be affirmed with safety, that it had never " been properly described; nor can the character of any " species, hitherto introduced into the books of any syste" matic naturalist, be considered as a just or competent $\therefore$ specific cliaracter of the present bird. It may be called "the fre-backed pheasant; and its essential character " may be delineated in the following terms: black " pheasant with a steel-blue gloss; the sides of the body " rufous; the lower part of the back fiery ferruginous; "the tail rounded? the two middle feathers, pale yel"low-brown." 
The eye looks in the country here in vain for the Batavia. common animals and vegetables, which it had been accustomed every day to meet in Europe. The most familiar bird about the house of the Embassador's host was the crown bird, as it was called at Batavia, which was not however the ardea paronina of Linnzus, but the columba cristata, having nothing, except its crest, in common with the former. The same gentleman had also, at his country house, some large cassowary birds, which, tho long in his possession, and having the appearance of tameness, sometimes betrayed the fierceness of their nature, attacking with their strong bill those who approached too near them. The vegetation of the country is likewise new. Even the parterres in the gardens are bordered, instead of box-wood, by the Arabian jessamine, of which the fragrant flowers adorn the pagodas of Hindostan. The Dutch, who are so fond of gardens in Holland, have transferred that taste, where it can, certainly, be cultivated with more success, and indulge it to a great extent at their houses a little way from the city of Batavia; but still within that fenny district, concerning which, an intelligent gentleman upon the spot used the strong expression, that the air was pestilential, and the water poisonous. Yet the country is every where so verdant, gay, and fertile; it is interspersed with such magnificent houses, gardens, avenues, canals, and drawbridges; and is so formed in every 
Batavia. respect to please, could health be preserved in it, that a youth coming just from sea, and enraptured with the beauty of every object he saw around him, but mindful of the danger there to life, could not help exclaiming, " what an excellent habitation it would be for immortals!"

The most tolerable season here is from March or April, to November; when the rains begin, and last the rest of the year. The sea breeze sets in about ten o'clock in the morning, and continues till four or five in the afternoon. It becomes then calm till seven or eight, when the land breeze commences, and continues at intervals till day-break, followed by a calm for the remaining hours of the twenty-four. Falurenheit's thermometer was, in Batavia road, during the Lion's remaining there, from eighty-six to eighty-eight degrees, and in the town, from eighty-eight to ninetytwo degrees; but its variations by no means corresponded to the sensations produced by the heat on the human frame; the latter being tempered by any motion of the air, which circumstance has little effect upon the thermometer. Nor are the animal sufferings here, from heat, to be measured by its intenseness at any given moment of the day, but by its persisting through the night; when, instead of diminishing, as it does in colder countries, sometimes twenty degrees, it keeps generally here within four or five of what it attains in the shade, when the sun is at its highest elevation. 
The native Javancse derive, however, one advantage at Batavia. least, from an atmosphere not subject to the vicissitudes of temperature experienced in the northern parts of Europe, where diseases of the teeth are chiefly prevalent; as they are here entirely exempt from such complaints. Their habit of living chiefly on vegetable food, and of abstaining from fermented liquors, no doubt contributes to this exemption. Yet such is the caprice of taste, that jet black is the favourite colour, and standard of beauty, for the teeth, amongst them; comparing to monkies those who keep them of the natural colour. They accordingly take care to paint, of the deepest black, all their teeth, except the two middle ones, which they cover with gold leaf. Whenever the paint or gilding is worn off, they are as attentive to replace it on the proper teeth, as the belles of Europe are to purify and whiten theirs.

The general reputation of the unhealthiness of Battavia for Europeans, deters most of those, who can resicle at home with any comfort, from coming to it, notwithstanding the temptations of fortunes to be quickly amassed in it. From this circumstance it happens, that offices and professions are often necessarily entrusted to persons little qualified to fill them. One of the clergymen, and the principal physician of the place, were both said to have originally been barbers. The United Provinces furnish even few military recruits. The rest 
Batavia. are chiefly Germans, many of whom are said to have been kidnapped into the service. Tho nominally permitted, after a certain length of time, to return home, they are, in fact, compelled to enlist for a longer time; the pay being too scanty to allow them to save enough to defray the expence of their passage to Europe. The government is accused of the barbarous policy of intercepting all correspondence between those people and their mother country; by which means they are deprived of the consolation of hearing from their friends, as well as of the chance of receiving such assistance, as might enable them to get home. One of these miserable men availed himself of an opportunity, which offered accidentally, of addressing, in his native German language, a gentleman of his own country belonging to the Embassy. He was in the utmost agitation, lest he should be observed holding converse with a person not under the Dutch government's control; and conjured him, in a few words, uttered with all the energy of heart-felt anguish, to forward a letter he meant to write to respectable relations he had in Germany. Unfortumately for this wretch, he had not then the letter ready; and he had never once afterwards the opportunity of delivering it. The duke of $W$ ürtemberg, in consequence of a bargain with the East India Company in Holland, had lately sent onc of his regiments to Batavia; but a large proportion, both of olficers and men, died within a twelvemonth. 
Every man who comes to settle in Batavia must take up arms in its defence. One of the Counsellors of the Indies, after mentioning all the pains taken by him and his colleagues in government, for guarding the settlement against external attacks, frankly acknowledged that their chief dependence was upon the havock which the climate was likely to make amongst the enemy's forces. Captain Parish thought, likewise, that "the " most effectual protection of that settlement from an " European enemy proceeded from its climate. Its for"tifications were, by no means, such as would be "deemed formidable in Europe; but when the diffi"culties were considered of forcing the passage of the " river, or of landing troops on other parts of the island, " it might, perhaps, be thought of greater strength than " it would, at the first view, have credit for. The de"fences of the river were the water fort, situated at its " entrance, having, mounted or dismounted, fourteen "guns and two howitzers. It consisted of a parapet, " originally well constructed, retained by a wall ; but " the parapet was much neglected, and the wall nearly " destroyed by the constant working of the sea. This "fort was protected on the land side by a noxious "swamp, and towards the sea, on the north-west, by " extensive flats, over which even boats could not pass. "The only good approach was that by the channel, " which it sees and defends. The next work upon the vol. 1 . $\mathrm{Kk}$ 
Batavia. "river was on the west shore, about a quarter of a mile "from the water fort. It is a battery mounting seven " guns, bearing down the river. Opposite to this was " a battery of six guns, facing the river; and two to " the eastward. This formed one flank of a line that " occupied the low land to the north-east of the town. "The line was a low breast-work of earth, that was "scarcely discoverable. The canals which intersect " the town joined the great canal, or river, at the dis" tance of half a mile from the entrance. Below the " junction a boom was laid, of wood, armed with iron "spikes. A little above was the castle, a regular square " fort, but without ravelins or other outworks. It had "two guns mounted on each flank, and two, or some" times three, on each face: they were not en barbette, " nor properly en embrasure, but in a situation between " both, having both their disadvantages, without the " advantage of either. The wall was of masonry, about " twenty-four feet high. It had no ditch; but a canal " surrounded it at some distance. It had no cordon. " The length of the exterior side of the work was about " seven hundred feet. The town is rectangular, three " quarters of a mile long, and half a mile broad, inclosed "by a wall of about twenty feet in height. Small "projections were constructed, of various forms, at " intervals of about three hundred and fifty feet. "These gencrally momnted three gums cach. It was 
"also surrounded by a canal, having several sluices. Batavia. "At short distances from the town, three or four small "star forts of earth were erected in particular passes, per" haps for defence against the inhabitants of the island. "The establishment of regular troops was one thou" sand two hundred Europeans, of whom three liun" dred were to be artillery, the rest infantry. But as " it was found impossible, on account of the climate, " to keep the number complete, recourse was had to the "natives, of whom five hundred were employed; so "that the establishment of European regulars was re" duced to seven hundred. There were also three hun" dred volunteers of the town, who were formed into " two companies; but they were not disciplined. The " irregulars were very numerous, consisting of enrolled "natives of Java, who were never embodied, and of "Chinese, of whom the Dutch were so jealous, as to "arm them with lances only. Much dependence was " not to be placed on the exertions of either of these "bodies, in favour of the Dutch; and as they lose many "of their European troops every year, their establish"ment appeared too small for any effectual resistance. "The chief protection of their ill-manned vessels lying " here, must be from the fortified island of Onrust, well "situated to command the channel that affords the prin"cipal passage into the road. The work upon that " island was of a pentagonal form; its bastions were 
Batavia. " small and low, not more than twelve feet the highest, " and not always connected by curtains. A few bat" teries were lately constructed on the outside of this "work, that bore towards the sea. On these and on " the bastions, about forty gums were mounted in diffe"rent directions. South of these was another island, " at the distance of a few hundred yards, on which two "batteries, mounting together twelve guns, had been " lately erected."

The castle is built of coral rock, brought from some of the adjoining islands, composed of that material; and has the advantage of a fortification of brick, in which cannon ball is apt to bury itself without spreading splinters, or shattering the wall. A part of the town wall is built of lava, which is of a dark blue colour, of a very hard dense texture, emits a metallic sound, and resembles, very much, some of the lava of Vesuvius. It is brought from the mountains in the centre of Java, where a crater still is smoking. No stone, of any kind, is to be found for many miles behind the city of Batavia. Marble and granite are brought thither from China, in vessels belonging to that country, commonly called junks, which generally sail for Batavia from the ports of the provinces of Canton and Fokien, on the sonthern and southcast coasts of that empire, laden chiefly with tea, porcelain, and silks.

In these junks great numbers of Chinese come con- 
stantly to Batavia, with exactly the same views that Batavia. attract the natives of Holland to it, the desire of accumulating wealth in a foreign land. Both generally belonged to the humbler classes of life, and were bred in similar habits of industry in their own country; but the different circumstances that attend them after their arrival in Batavia put an end to any further resemblance between them. The Chinese have, there, no way of getting forward but by the continuance of their former exertions in a place where they are more liberally rewarded; and by a strict economy in the preservation of their gains. They have no chance of advancing by favour; nor are public offices open to their ambition; but they apply to every industrious occupation, and obtain whatever either care or labour can accomplish. They become, in town, retailers, clerks, and agents; in the country they are farmers, and are the principal cultivators of the sugar-cane. They do, at length, acquire fortunes, which they value by the time and labour required to earn them. So gradual an acquisition makes no change in their disposition, or mode of life. Their industry is not diminished, nor their health impaired. The Dutch, on the contrary, who are sent out by the Company, to administer their affairs in Asia, become soon sensible that they have the power, wealth, and possessions of the country at their disposal. They who survive mount quickly into offices that are lucrative, and 
Batavia. not, to them, laborious. Their influence, likewise, enables them to speculate in trade with vast advantage. The drudgery and detail of business are readily undertaken by the Ghinese; who, like the native Banyans and Debashes in Calcutta and Madras, are employed as subordinate instruments, while their principals find it difficult, under such new circumstances, to retain their former habits, or to resist a propensity to indolence and voluptuousness, tho often attended with the sacrifice of health, if not of life. Convivial pleasures, among others, are frequently carried to excess.

In several houses of note throughout the settlement the table is spread in the morning at an early hour: beside tea, coffee, and chocolate, fish and flesh are served for breakfast; which is no sooner over, than Madeira, claret, gin, Dutch small beer, and English porter, are laid out in the portico before the door of the great hall, and pipes and tobacco presented to every guest, and a bright brass jar placed before him to receive the plilegm which the tobacco frequently draws forth. This occupation continues sometimes, with little interruption, till near dinner time, which is about one o'clock in the afternoon. It is not very uncommon for one man to drink a bottle of wine in this manner before dinner. And those who have a predilection for the liquor of their own country, swallow several bottles of Dutch small beer, which, they are told, dilutes their blood, and 
affords plenty of fluids for a free perspiration. Imme- Batavia. diately before dinner, two men slaves go round with Madeira wine, of which each of the company takes a bumper, as a tonic or whetter of the appetite. Then follow three female slaves, one with a silver jar containing water, sometimes rose water, to wash; a second with a silver bason and low cover of the same metal, pierced with holes, to receive the water after being used; and the third with towels for wiping the lands. During dinner a band of music plays at a little distance: the musicians are all slaves; and pains are taken to instruct them. A considerable number of female slaves attend at table, which is covered with a great variety of dishes; but little is received, except liquors, into stomachs already cloyed. Coffee immediately follows dinner. The twenty-four hours are here divided, as to the manner of living, into two days and two nights; for each person retires, soon after drinking coffee, to a bed, which consists of a mattrass, bolster, pillow, and chintz counterpane, but no sheets; and puts on his night dress, or muslin cap and loose long cotton gown. If a bachelor, which is the case of much the greatest number, a female slave attends to fan him while he sleeps. About six they rise, dress, drink tea, take an airing in their carriages, and form parties to spend the evening together to a late hour. The morning meetings consist generally of men, the ladies seldom choosing to appear till evening. 
Batavia. Few of these are natives of Europe, but many are descended from Dutch settlers here; and are educated with some care. The features and outlines of their faces are European ; but the complexion, character, and mode of life, approach more to those of the native inhabitants of Java. A pale languor overspreads the countenance, and not the least tint of rose is seen in any cheek. While in their own houses, they dress like their slaves, with a long red checkered cotton gown descending to the ankles, with large wide sleeves. They wear no head dress, but plait their hair, and fasten it with a silver bodkin on the top of the head, like the country girls in several cantons of Switzerland. The colour of their hair is almost universally black; they anoint it with the oil of the cocoa-nut, and adorn it with chaplets of flowers. When they go abroad to pay visits, or to take an airing in their carriages, and particularly when they go to their evening parties, they dress magnificently, in gold and silver spangled muslin robes, with a profusion of jewels in their hair, which, however, is worn without powder. They never attempt to mold or regulate the shape, by any fancied idea of elegance, or any standard of fashion; and, consequently, formed a striking contrast with such few ladies as were lately arrived from Holland, who had powdered hair and fair complexions, had contracted their waists with stays, wore large head dresses and hoops, and per- 
severed in the early care of forcing back the elbows, Baravia. chin, and shoulders. Every native lady is constantly attended by a female slave handsomcly habited, who, as soon as her mistress is seated, sits at her leet before her, on the floor, holding in her hands her mistress's gold or silver box, divided into compartments, to contain areca nut, cardamom seeds, pepper, tobacco, and slacked lime; all which, mixed together in due proportions, and rolled within a leaf of betel, constitute a masticatory of a very pungent taste, and in general use. When, in the public assemblies, the ladies find the heat disagreeable, they retire to free themselves from their costly but inconvenient habits, and return, without ceremony, in a more light and loose attire; when they are scarcely recognizable by strangers. The gentlemen follow the example, and throwing off their heavy and formal dresses, appear in white jackets, sometimes indeed adorned with diamond buttons. The elderly gentlemen quit their periwigs for night-caps. Except in these moments, the nembers of this government have always combined their personal gratification, with the eastern policy of striking awe into vulgar minds, by the assumption of exterior and exclusive distinctions. They alone, for instance, appear abroad in crimson velvet. Their carriages are distinguished by peculiar ornaments. When met by others, the latter must stop, and pay homage to the former. One of the gates of the city is opened only VOL. I. L. I 
Batavis to let them pass. They certainly succeed in supporting absolute sway over a vast superiority in number of the descendants of the original inhabitants of the country, as well as of the slaves imported into it, and of the Chinese attracted to it by the hope of gain; those classes, tho healthy, active, and as if quite at home, readily obeying a few emaciated Europeans: such is the consequence of dominion once acquired; the prevalence of the mind over mere bodily exertions, and the effect of the combination of power against divided strength.

The native Javanese are in general too remote from civilization, to have any wants that are not easily satisfied in a warm and fertile climate. No attempt is made to enslave their persons; and they find the government of the Dutch less vexatious than that of others, who divide some share of the sovereignty of the island with them. The Sultan of Mataran rules to the east, the Emperor of Java in the centre, and the King of Bantam to the west; while the coast and effective power almost entirely belong to Holland. Those other sovereigns are descended from foreigners also; being Arabians, who imported the Mahometan religion into Java, and acquired the dominion of the country; a few inhabitants in the mountains excepted, who have preserved their independence and their faith, and among other articles, that of the transmigration of souls. According to the Dutch accounts, nothing can be more tyrannic than 
those Mahometan rulers. The Emperor is said to mainBataria. tain his authority by an army of many thousand men, dispersed throughout his territories, beside a numerous female guard about his person. These military ladies are trained, it seems, to arms, without neglecting those accomplishments which may occasion a change in the occupation of some among them, rendering them the companions, instead of being the attendants, of his Imperial Majesty. This singular institution may owe its origin to the facility of obtaining recruits, if it be true, as the same accounts pretend, that the number of female births exceeds, very considerably, that of males in Java.

Most of the slaves are imported into it from Celebes and other eastern islands. They do not form a corps; or have any bond of union. Nor is the general conduct of their owners towards them calculated to aggravate the misfortune of being the property of others. They are not forced to excessive labour. They have sufficient sustenance; but many of the males among them, who had formerly, perhaps, led an independent life, till made captives in their wars, have been found to take offence against their masters, upon very slight occasions, and to wreak their vengeance by assassination. The apprehension of such an event is among the motives for preferring, at Batavia, female slaves, for every use to which they can be applied; so that the number purchased of them much exceeds that of the other sex. The slaves 
Batavia. when determined on revenge often swallow, for the purpose of acquiring artificial comage, an extraordinary dose of opium, and soon becoming frantic as well as desperate, not only stab the objects of their hate, but sally forth to attack, in like manner, every person they meet, till self-preservation renders it necessary to destroy them. They are said in that state to be rmming a muck, and instances of it are not more common among slaves, than among free natives of the country, who, in the anguish for losing their money, effects, and sometimes their familics, at gaming, to which they are violently addicted, or under the pressure of some other passion or misfortune, have recourse to the same remedy, with the the same fatal effects.

A fondness for play, and a fondness for opium, are not uncommon among the Chinese also at Batavia; but the habits of restraint and moderation in which they are bred, and the cantious principles instilled into them, curb their disposition, and prevent them from falling into the same excesses. They are, indeed, much more capable of conceiring formidable designs against the government, and in the year 1740 a considerable number of Chinese, residing in different parts of the country , joined in a revolt under the command of a man, who said he was descended from an Emperor of China; and who, being joined also by sereral Javanese, attacked Batavia, but was repulsed. A fire. some days alterwarels, took place among the 
Chinese buildings in that city, and several of the owners were accused of opposing, with arms, the extinguishment of it, with a view, as was attributed to them, of the conflagration's spreading to the whole town, that, in the confusion, they might assassinate the Europeans, and become masters of the place. The alarm was such, that the Dutch government gave instant orders to put all the Chinese heads of families to death; and the sailors from the vessels in the road were brought ashore, and induced, for the sake of plunder, to share in putting this bloody edict into execution. The unfortunate Cihinese made not the least resistance. This dreadful deed was not approved by the directors of the Company in Holland; and much apprehension being entertained that the fact would excite the indignation of the Emperor of China, deputies were sent to him the following year, to apologize for the measure, as founded upon necessity. Those deputies were agreeably surprised on finding that the Emperor calmly answered, that " he was little solicitous "for the fate of unworthy subjects, who, in the pursuit " of lucre, had quitted their country, and abandoned "the tombs of their ancestors."

For those, however, of their ancestors, whom they have lost since their emigration to Batavia, the survivors seem to have the utmost veneration. A considerable tract of ground is set apart for their remains; and much expence incurred in erecting monuments to their memory. 
Batavia. Every family above indigence has a separate vault, generally surrounded by a wall, in the form of a horse shoe, raised obliquely, so as that the opening of the shoe is level with the ground; and opposite to that opening is the door into the vault, upon which are several columns of inscriptions. When a Chinese of note here dies, his nearest relations announce the melancholy event, in form, to all the branches of the family. The body is washed, perfumed, and dressed in the best apparel of the deceased. The corpse is then seated in a chair; and his wives, children, and relations, fall down before it and weep. On the third day, it is put into a coffin, which is placed in one of the best apartments, hung for the occasion with white linen cloth, the colour, with them, of mourning. In the middle of the apartment an altar is erected, and on it the portrait of the deceased is placed, with incense burning near it. The sons stand on one side of the coffin, dressed in white coarse linen, and making every sign of sorrow; while the mother and female relitions are heard lamenting behind a curtain. On the day of burial, the whole family assembles, and the corpse is conveyed to the grave with much solemn pomp. Images of men and women, relations of the family, (as amongst the ancient Romans) and even of animals, together with wax tapers and incensories, are carried first in the procession. Then follow the priests with musical instruments, and after them the 
corpse upon a bier, attended by the sons of the deceased, clothed as before in white, and leaning upon crutches, as if disabled, through grief, from supporting themselves erect. The female relations are carried in chairs, hung with curtains of white silk, concealing them from view; but their lamentations are distincti y heard; and other women are hired, who are trained to utter shrieks still louder and more piercing; which last is also a custom still retained in some parts of Europe. Previous to the funeral, a table with fruits and other catables is laid before the corpse, and wax figures of servants placed on each side, as attendants upon it.

The Chinese are said to be now again as numerous as ever in and about Batavia; for however imminent the danger, to which the Dutch allege they were exposed by the intended former insurrection of this people, and however cruel and unjustifiable the Chinese consider the conduct of the Dutch towards them, at that time, the occasion they have for each other has brought them again together; and it is acknowlerlged by the latter, that the settlement could scarcely subsist without the industry and ingenuity of the former. It is said, indeed, that also in the Philippine islands the natives can be turned to little use; and the Spaniards are so indolent, that the Chinese there are as numerous and as necessary as in Java.

Both those European nations, falling in to the faults, 
Batavia. may share the fate, of their predecessors, the Portugneze. There is a race of the latter still remaining at Batavia; many of them are artificers, and servants in families. Even the ladies here not only speak the language of the country, and the Dutch, but find it convenient, likewise, to learn Portugueze, which, continuing still to be understood in most of the old European settlements in Asia, shews how deep a root that nation had taken during its prosperity in this quarter of the world. Their language now has survived their dominion, and even their religion here; their descendants having gradually embraced the Calvinistic tenets of the government; a singular instance, perhaps, of Portugueze prayers and congregation out of the pale of the popish communion.

It is a plain indication of the inhabitants of the interior parts of Java not being able or inclined to consume many imported and costly manufactures, that the shops of the capital are not like those of Rio de Janeiro, for example, which contain complete assortments of the most curious manufactures, for the use of the numerous and thriving Portugueze in the inner settlements; whereas at Batavia, there are few other than brokers' shops, dealing in inferior goods, and second-hand articles. But there are large storchouses for holding the rich products of the Molncca or spice islands, to be distributed from hence to the rest of the world; beside coffee, pepper, sugar, and arrack, produced upon the spot. The nutmeg, 
mace, and clove, so long confined to the very small Batavia. islands of Ternate, Banda, and Amboyna, are, no doubt, capable of being cultivated in other soils; but the Dutch Company, in order to preserve that trade entirely to themselves, and to prevent even their own commodities from overstocking the market, which might affect their price, fell upon a most extraordinary measure, which was the establishment of persons appointed with strict instructions, and considerable means of excution, under the name of extirpators, for the purpose of actually rooting out, from every place where they could penetrate, the trees which bear these grateful and valuable productions, except on such small spots, and in such few numbers, as promised to secure the exclusive property and sale of them to the contrivers of a project thus calculated to counteract the bountiful intent of nature. The nutmeg had been accordingly destroyed by the extirpators in all the Moluccas, except Banda; and a dreadful eruption of a volcano in that island, a very few years ago, so effectually buried in its ashes, or otherwise injured the vegetable productions there, that, for some time, no slight apprehension was entertained of a great diminution in the supply of that valuable spice, and of the Dutch Company consequently becoming losers by their inordinate thirst of gain. But their delegates are become now so much more liberal, that one of them gave, from the medical garden at Batavia, a young growing vol. I. M m 
Batavia. nutmeg plant, and a nut, in a state supposed capable of germination, to a person belonging to the Embassy, who committed it immediately to the care of a gentleman, then bound for England, in order to be put in his Majesty's rich botanical garden at Kew ; from whence, had the plants succeeded there, this tree might have been propagated in the British plantations in the West Indies; in like manner as the coffee tree was transplanted to the French West Indies, in the beginning of the present century, from a very few specimens in the botanic garden at Paris. The nutmeg plant, however, suffered in the passage, and was left at St. Helena.

The nutmeg tree is a beautiful vegetable. The stem, with a smooth brown bark, rises perfectly straight. Its strong and numerous branches proceed regularly from it in an oblique direction upwards. They bear large oval leaves pendulous from them, some a foot in length. The upper and outer surface of the leaf is smooth, and of a deep agreeable green. The under and inner surface is marked with a strong nerve in the middle of the leat, from the foot-stalk to the point; and from this middle nerve others proceed obliquely towards the point and edges of the leaf; but what distinguishes most this inner surface, is its uniform bright brown colour, without the least intermixture of green, and as if strewed all over with a fine brown powder. The whole leaf is characterized by its fragrant odour, sufficiently denoting the 
fruit which the tree produces. This fruit, when fresh, is about the size and figure of a common nectarine. It consists of an outward rind, between which and the inward shell, is lound a reticulated membrane, or divided skin, which, when dried, is called the mace. What is known by the name of nutmeg, is the kernel within the shell, and is soft in its origiral state.

The same medical garden at Batavia contains a clove tree. The clove is only the germ of the fruit with the flower cup containing it. The leaf is oval, smooth, small, narrow, tender, and aromatic. The camphor tree bears leaves not unlike those of the clove, but stronger, and together with every other part of the tree smells of that substance; it is extracted, by boiling, in common water, the root, trunk, branches, and leaves, when the camphor, rising to the surface of the boiling water, is easily separated from it. The cinnamon tree may be distinguished, not only by the three nerves which always regularly divide the inner surface of its oval leaf, but also by the same fragrant smell, which issues on bruising any part of the leaves or branches of the tree, that is known to be afforded by its bark. The pepper, which is observed to grow always best very near to the equator, is a creeping plant or vine generally supported on a living tree. Its leaves, which are of a dark green colour, are not very unlike those of the common hazel, but are extremely pungent. The pepper grows in clusters, like 
Batavia. the grape, but of a much smaller size. It is a species of the pepper plant that affords the leaf called betel, chewed so universally by the southern Asiatics, and serving for the inclusure of a few slices or bits of the areca, from thence erroneously called the betel, nut. The areca nut tree is among the smallest of the tribe of palms, but comes next in beauty to the mountain cabbage tree of the West Indies; the latter differing, chiefly in its size and amazing height, from the areca nut tree, the diameter of whose jointed trunk seldom exceeds four inches, or height, twelve feet. But the symmetry of each is perfect; the columns of a temple cannot be more regular than the trunk, which rises without a branch, while the broad and spreading leaves which crown the top, form the ornamented capital. 'The areca nut, when dried, has some similitude in form and taste to the common nutmeg, but is of a less size.

Concerning the supposed upas, or poison tree of Java, of which the account by Foersch attracted little notice, at least in England, till it was admitted in a note to Doctor Darwin's celebrated poem of the Botanic Garden, enquiries were made by Doctor Gillan, and others belonging to the Embassy. Foersch had certainlybeen a surgeon for some time in Java, and had travelled into some parts of the interior of the country; but his relation of a tree so venomous as to be destructive, by its exhalations, at some miles distance, is compared there to the fictions of Baron 
Munchausen, or as a bold attempt to impose upon Batavia. the credulity of persons at a distance: yet as it was thought a discredit to the country to be suspected of producing a vegetable of so venomous a quality, a Dutch dissertation has been written in refutation of the story. It appears from thence that information was requested, on the part of the Dutch government of Batavia, from the Javanese prince, in whose territories this dreadful vegetable was asserted to be growing; and that the prince, in his answer, denied any knowledge of such a production. Rumphius, indeed, a respectable author in natural history, of the last century, mentions a tree growing at Macassar, to which he gives the name of toxicaria; and relates that not only the red resin contained a deadly poison, but that the drops falling from the leaves upon the men employed in collecting this resin from the trunk, produced, unless they took particular care in covering their bodies, swellings and much illness; and that the exhalations from the tree were fatal to some small birds attempting to perch upon its branches. But many of the particulars of this account, however far removed from that of Foersch, are given not upon the author's own observation, and may have been exaggcrated. It is a common opinion at Batavia that there exists, in that country, a vegetable poison, which, rubbed on the daggers of the Javanese, renders the slightest wounds incurable; tho some European practitioners 
Batavia. have of late asserted, that they had cured persons stabbed by those weapons; but not without having taken the precaution of keeping the wound long open, and procuring a suppuration. One of the keepers of the medical garden at Batavia assured Doctor Gillan, that a tree distilling a poisonous juice was in that collection; but that its qualities were kept secret from most people in the settlement, lest the knowledge of them should find its way to the slaves, who might be tempted to make an ill use of it. In the same medical garden, containing, it seems, hurtful, as well as grateful, substances, is found also the plant from whence is made the celebrated gout remedy, or moxa of Japan, mentioned in the works of Sir William Temple; it is nothing more than that species of the artemesia, hence called moxa, of Linnæus, which is converted, by a more easy process than would answer with other plants, into a kind of soft tinder, capable, when set on fire, of acting as a gentle caustic, and continuing to burn with an equal and moderate heat.

The whole country abounds with esculent fruits; and, unlike the northern regions, whose soil apparently is barren during the tedious season of the winter, and brings little to maturity till towards autumn, the presents of nature, within the tropics, are distributed in plenty throughout the whole circle of the year. In March, among other fruits, the mangosteen was ripe. It abounds in Java, where it is considered as the most delicious of all 
fruits. It is rarely found, in the warmest latitudes, to the northward of the equator, and is neither in the West Indies, or on the continent of India. It is about the size of a nonpareil apple, and consists of a dark-red, thick and firm rind, containing from five to seven seeds, of which a white pulp that covers them, is the only part that is eaten. It is of a delicate subacid taste; not much differing from, but preferable to, the same sort of substance, inclosing the kernels of the sour sop in the West Indies. Pine apples are planted here, not in gardens, but in large fields; and are carried, like turnips, in heaps, upon carts to market, and sold for considerably less than a penny each, where money is cheaper than in England. It was a common practice to clean swords, or other instruments of steel or iron, by running them through pine apples, as containing the strongest and cheapest acid for dissolving the rust that covered them. Sugar sold for about five pence a pound. All sorts of provisions were cheap; and the ships' crews fed on fresh meat every day.

In a place so low, warm, and marshy, the number of noxious reptiles must undoubtedly be considerable; but not many accidents happen from them. The lacerta iguana, or guana, tho chiefly a land animal, cliffers not much, in its exterior form, from the lacerta crocodilus, or crocodile, which frequents the canals and rivers of this country. The former, however, is a harmless, the 
Batavia. other, a most voracious animal. It certainly is an object of fear; and, by no very uncommon transition of sentiment, gradually becomes an object of veneration; and offerings are made to it, as to a deity. When a Javanese feels himself diseased, he will sometimes build a kind of coop, and fill it with such eatables as he thinks most agreeable to the crocodiles. He places the coop upon the bank of the river or canal, in the perfect confidence that, by the means of such offerings, he will get rid of his complaints; and persuaded, that if any person could prove so wicked as to take away those viands, such person would draw upon himself the malady, for the cure of which the offering was made. The worship of the crocodiles is indeed a folly among men of an ancient date; as Herodotus, in that part of his history styled Euterpe, expressly says, that "among some of the " Egyptian tribes the crocodiles are sacred, but regarded "as enemies among others. The inhabitants, in the " environs of Thebes, and the lake Moeris, are firmly " persuaded of their sanctity; and both these tribes " bring up and tame a crocodile, adorning his ears with " ear-rings of precious stones and gold, and putting or" namental chains about his fore feet. They also re"gularly give him victuals, offer victims to him, and " treat him in the most respectful manner while living, " and, when dead, embalm and bury him in a conse" cratcel colfin." 
To this superstition, it is possible that the observation Batavia. may have contributed, of the few accidents which happen, notwithstanding the voraciousness of those animals, without reflecting upon the unvicldiness of their bodies, or inflexibility of their necks, and consequent difficulty of turning in pursuit of prey. The presence of them does not prevent the natives, as well as the slaves of both sexes at Batavia, from plunging promiscuously, once or twice a day, into the river and canals. Those canals are continued through the country, to the foot of the mountains, many miles distant from the coast. The principal cultivation there is rice; and so much does the climate yield to culture, that this production may be seen, at the same time, in the various stages of its growth; at first, its tender leaves just peeping above the water which inundates the soil; in its second stage, with its withering tops, in consequence of having been transplanted, and before the second spring of vegetation has taken effect; and in its last stage, when the ears are bending with the weight of the ripened grain. Rice happened to be uncommonly scarce when the Lion was at Batavial but it was still sold under a penny for a pound weight. In the ground ploughed for the purpose of planting it, the furrows appeared to consist as much of water as of soil. Buffaloes are always employed in this labour, for which they are peculiarly adapted, being ahmost an amphibious animal, in the vOI. I. $\mathrm{Nn}$ 
Batavia. sense of delighting in water, and remaining to the neck in ponds or rivers, except when obliged to quit them in search of food. Of these animals, there are two species or varieties here; the most common are of a slight make, the skin of a dirty dun colour, very thinly covered with hair; the head elongated, and muzzle pointed; no dewlap; and the horns uncommonly long, turned so much backwards, that the animal must rather but like a ram, than toss with them like a bull. The other buffalo varies much in the colour of its skin and hair, with the latter of which it is more thickly covered; it has short, nearly erect, horns, a strong neck, larger limbs, and appears of a wilder nature; having few specific qualities in common with the first, except the propensity of keeping in the water. The buffaloes are yoked to carts, with which they wade, with infinite labour, through deep and miry roads, running parallel to others kept in excellent order, but reserved for the carriages of gentlemen, leading to their country seats. Of these, many, indeed, now are empty, the number of new comers not being sufficient to replace those who die, or hasten to escape from a country, where they might otherwise be retained for ever.

In the districts round Batavia, immediately subject to the Dutch, it is calculated that near fifty thousand Javanese families are settled, containing six persons, upon an average, to a family, or three hundred thousand persons in the 
whole. The city of Batavia, including the suburbs, contains near eight thousand houses. Those of the Chinese are low, and crammed with people. The Dutch houses are well built, clean, and spacious, and their construction, for the most part, well suited to the climate. The doors and windows are wide and lofty. The ground floors are covered with flags of marble, which being sprinkled frequently with water, give a pleasant coolness to the apartment; but a considerable proportion of those was untenanted; which denoted a declining settlement. Among other circumstances which announced the same, were those of the Company's vessels lying useless in the road, for want of cargoes to fill, or men to navigate them; no ships of war to protect their commerce, even against pirates, who attacked their vessels sometimes in the sight of Batavia road; an invasion threatened from the Isle of France; the place in no condition of defence, particularly against an enemy less affected by the climate than Europeans; sometimes as many of the troops in hospitals as fit for duty; commissioners expected from Holland to reform abuses. Such a commission, implying a general suspicion, could not be welcome; nor was it quite certain whether, in some minds, its arrival, or that of the enemy, was deprecated the most cordially.

In the midst of such gloomy prospects their attention to their guests was not diminished. The Embassador 
Batavia. being indisposed, he was pressed to spend some time at one of the Governor's houses, at a considerable distance from town, and in a very pleasant and healthy spot, amidst the mountains. But lie thought it his duty to proceed upon his mission, as soon as the ships were supplied with what they wanted; and he embarked from Batavia on the seventeenth of March, in order to be ready to enter into the Straits of Banca as soon as the monsoon, or periodical current of the wind, blowing in these seas for about six months with a northerly, and six with a southerly direction, should be favourable for vessels bound to China from the southward. The change which is gradual, begins frequently to take place about this time.

The Lion in her passage from Batavia, touched upon a new or unnoticed knoll, with thee fathoms depth of water over it. This knoll did not exceed the size of a long boat, with six or seven fathoms water all round it. From this spot the westernmost windmill on the Careening istand bore south-south-cast; and the hospital on Purmerent istand sonth-east by east. As the ship touched by the stem, the gums at that extremity were moved forward towards the head; the kedge or small anchor was carried out, and the ship was warped or towed towards it, and got clcar without any damage. Had the knoll risen nearer to the surface, the accident might have been attended with serious consequences; 
and the want of a tender, such as the Jackall was meant to be, was now much felt, as she might have preceded the larger sinips, and sounded the depth of water in any unknown or suspected place. The Company's Commissioners at Canton had destined two small vessels belonging to the Company for this purpose; but in their late dispatches to the Embassador, received by him at Batavia, they expressed their regret that those vessels were still otherwise employed. It appeared that even should the Jackall join, another vessel would still be useful; and the Embassador sent back to Batavia to purchase such a one as the service required; to which, as a mark of respect to Admiral the Duke of Clarence, he gave his Royal Highness's name.

The little squadron immediately proceeded towards the opening which leads to the Straits of Banca. The island of Sumatra, on its eastern side, forms the western side of those Straits, as its southern extremity forms the northern side of the Straits of Sunda. Nearly in the angle made by those last mentioned Straits, and with a view into those of Banca, is situated North Island, already mentioned as the rendezvous agreed upon in case of separation. The depth of water is very irregular near that island, the water shoaling, in some spots, in one cast, from twelve to seven fathoms, and in others from seven to four. This irregularity was often observed throughout the Straits; beside what was occa- 
Straits of sioned by shoals of coral so very near the surface as to Sunda. be easily distinguished by the whitened sheet of water over them,

Very soon after the Lion's return to this spot, the long lost Jackall came into sight. It had been conjectured that in the stormy night, in which she lost company of the ships, or in her attempt afterwards to follow them, she had met with some severe misfortune. She had been manned by a part of the Lion's crew; and their former companions, who knew not then of Great Britain's being at war, could not have even the consolation of supposing their friends, tho captive, yet alive. The joy of seeing her was very general: she had, in fact, being damaged in the beginning of the voyage, returned into port to repair; and afterwards used every diligence to join the ships. She was obliged to stop, for refreshments, a few days at Madeira, where she arrived a short time after the Lion had left it. She pursued the latter to St. Jago, which she reached, likevise, some days too late. From thence to North Island she did not come once to anchor. She was what navigators call a good sea-boat, being compactly built, and little liable to perish by mere foul weather; but neither did she afford much shelter against the hardships of a rough voyage, or make her way so quickly as larger vessels against violent waves. Her provisions were damaged by salt water; and her crew was reduced to a very scanty pittance when she 
joined the Lion. Mr., now Lieutenant, Saunders, who commanded her, got much credit for his conduct throughout the voyage,

She was very soon ready to accompany the Lion, but the monsoon was still adverse; this circumstance was the more regretted, as the crews of both ships now began to be very sickly. Their commanders had, indeed, the satisfaction of having past six months, from leaving Portsmouth, without losing a man, out of six hundred persons. Such a circumstance seldom happens any where. The proportion of deaths, in a similar period, in the healthiest spot ashore, is, at least, one to every hundred, and in London two. It must be confessed, however, that the seeds of dangerous diseases had taken root among the crews. The evil consequences of a sea life, and of a hot climate, began to show themselves; and the number of persons on the sick list increased considerably. The ships often moved to different parts of the coasts of Java and Sumatra, in order to find out the healthiest and coolest spot, where they might wait for the favourable moment of proceeding further.

It occurred to the mathematical gentlemen, on board the ships, to employ their leisure in measuring a base on shore, (they having the advantage of an excellent instrument for taking angles,) in order to ascertain the accuracy of the former charts of the northern entrance into the Straits of Sunda. With this view a level beach 


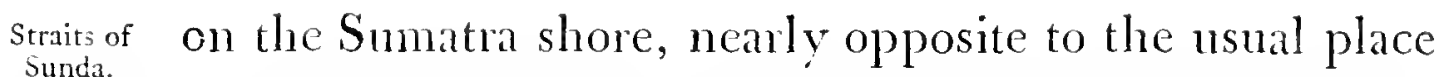
sunda. of anchorage, was chosen as most convenient for the purpose. The northern extremity of the base commenced near the watering place; and was continued from thence to the distance of eighteen chains sixty-five links, or four hundred and ten yards, making with the meridian an angle of twenty-eight degrees. From hence it was prolonged, as nearly in the same direction as the trending of the shore would allow, twenty-five chains or five hundred and fifty yards further. From the extremities of this base, sets of angles were taken, with a considerable degree of accuracy, by a theodolite of Mr. Ramsden's, and the situations of North Island, Pulo Sina close to it, the anchorage of the Lion and Hindostan, the three islands close to each other called the Sisters, and Pulo Coppia were hence determined. Pulo Sina, Pulo Coppia, and one of the Sisters were afterwards used as stations to ascertain the eastern and western points of Thwart-the-way, Button Island, and Nicholas Point on the Isle of Java, as also to verify the situations of the first mentioned places, as they had been determined from the first base. The Hindostan bcing about to quit her station at North Island, and stand over to Nicholas Bay, on the nosth side of Java, a good opportunity offered for extending the survey from Nicholas Point to the sonthward, as far as Angeree Print. 
The ship having brought to in the bay, the latitude of her anchorage was found by a meridional altitude of the sun, and the bearing of North Island taken carefully with a compass, mounted with a pair of sights to direct the eye, commonly called an azimuth compass; and, in order to obtain the distance of the ship from Pulo Salier, a small island in the bay, with more precision than merely by computation, the deck of the Hindostan, from stem to stern, was assumed for a base; from each extremity of which, angles were observed with two sextants at the same instant of time; and the distance calculated from thence trigonometrically. The ship being very near the island, this method was sufficiently correct. The latitude of Pulo Salier, was found to be five degrees, fifty minutes, thirty seconds, south of the equator; and its longitude, by an immersion of the first satellite of Jupiter observed through two telescopes placed on the island, proved to be one hundred and five degrees, fifty-six minutes, thirty seconds east, on computing by the apparent time of the immersion of the satellite at Greenwich, as given in the Nautical Ephemeris.

The latitude of Nicholas Point was found to be five degrees, fifty minutes, forty seconds south; and the longitude, deduced from the abovementioned observation of Jupiter's satellite, one hundred and five degrees, fiftyfour minutes, thirty seconds east. From various intersections and observations, the latitudes of the following vol. I. Oo 
Straits of places were determined; and their longitudes deduced Sunda. also from the said observation.

South Latitude.

$\begin{array}{lllllll}\text { Java head - } & 6^{\circ} & 47^{\prime \prime} & & 104^{\circ} & 50^{\prime} & 30^{\prime \prime} \\ \text { The three Sisters } & 5 & 42 & & 105 & 41 & 36 \\ \text { Thwart-the-way } & 5 & 55 & & 105 & 43 & \\ \text { North Island - } & 5 & 38 & & 105 & 43 & 30 \\ \text { Angeree Point } & 6 & 2 & & 105 & 47 & 30 \\ \text { Cap - - } & 5 & 58 & 30 & 105 & 48 & 30 \\ \text { Button - } & 5 & 49 & & 105 & 48 & 30\end{array}$

The rate of going of the several time-keepers was easily ascertained ashore, by observing, on subsequent nights, the appearance of any of the fixed stars in a particular point of the heavens. On the occasion of one of those observations, an alarming circumstance occurred. As Doctor Dinwiddie was going to apply his face close to a tree, in order to be ready, in the proper position, to observe a passing star, while some other person was to have his eye upon the time-keeper, a snake, of no mean length, which had crept along the trunk of the tree, and within the bark that had been loosened from it, luckily shewed its head soon enough to put the gentlemen on their guard, and fix upon another tree for pursuing their observations.

They had afterwards occasion to visit the small islands 
of the Cap and Button, differing much in appearance from the level islands already mentioned; being so steep and rugged, that it was difficult to get ashore upon them. At a little distance, they might be mistaken for the remains of old castles, mouldering into heaps of ruins, with tall trees already growing upon the tops; but, at a nearer view, they betrayed evident marks of a volcanic origin. Explosions from subterraneons fires, produce, for the most part, hills of a regular shape, and terminating in truncated cones; but when from a subaqueous volcano, eruptions are thrown up above the surface of the sea, the materials, falling back into the water, are more irregularly dispersed, and generally leave the sides of the new creation, naked and misshapen, as in the instance of Amsterdam, and of those smaller spots called, from some resemblance in shape, the Cap and Button.

In the Cap were found two caverns, running horizontally into the side of the rock; and in these were a number of those birds' nests, so much prized by Chinese epicures. They scemed to be composed of fine filaments, cemented together by a transparent viscous matter, not unlike what is left by the foam of the sea, upon stones alternately covered by the tide, or those gelatinous animal substances found floating on every coast. The nests adhere to each other, and to the sides of the cavern, mostly in rows, without any break or interruption. The birds that build these nests are small grey swallows, 
Straits of with bellies of a dirty white. They were flying about

sunda. in considerable numbers; but they were so small, and their flight so quick, that they escaped the shot fired at them. The same nests are said also to be found in deep caverns, at the foot of the highest mountains in the middle of Java, and at a distance from the sea, from which the birds, it is thought, derive no materials, either for their food, or the construction of their nests; as it does not appear probable they should fly, in search of either, over the intermediate mountains, which are very high, or against the boisterous winds prevailing thereabouts. They feed on insects, which they find hovering over stagnated pools between the mountains, and for catching which, their wide-opening beaks are particularly adapted. They prepare their nests from the best remnants of their food. Their greatest enemy is the kite, who often intercepts them in their passage to and from the caverns, which are generally surrounded with rocks of grey limestone, or white marble. The nests are placed in horizontal rows at different depths, from fifty to five hundred feet. The colour and value of the nests depend on the quantity and quality of the insects caught, and, perhaps, also on the situation where they are built. Their value is chiefly determined by the uniform fineness and delicacy of their texture; those that are white and transparent being most estcemed, and fetching often in China their wejght in silver. These nests are a considerable 
object of traffic among the Javanese; and many are employed in it from their infancy. The birds having spent near two months in preparing their nests, lay each two eggs, which are hatched in about filteen days. When the young birds become fledged, it is thought time to seize upon their nests, which is done regularly thrice a year, and is effected by means of ladders of bamboo and reeds, by which the people descend into the cavern; but when it is very deep, rope ladders are preferred. This operation is attended with much danger; and several break their necks in the attempt. The inhabitants of the mountains generally employed in it, begin always by sacrificing a buffalo, which custom is constantly observed by the Javanese, on the eve of every extraordinary enterprize. They also pronounce some prayers, anoint themselves with sweet-scented oil, and smoke the entrance of the cavern with gum benjamin. Near some of those caverns a tutelar goddess is worshipped, whose priest burns incense, and lays his protecting hands on every person, preparing to descend into the cavern. A flambeau is carefully prepared at the same time, with a gum which exudes from a tree growing in the vicinity, and is not easily extinguished by fixed air or subterraneous vapours. The swallow, which builds those nests, is described as not having its tail feathers marked with white spots, which is a character attributed to it by Linnæus; and it is possible that there 
Sumatra. are two species, or varieties, of the swallow, whose nests are alike valuable.

Nothing seemed to be known about these nests at the southern extremity of Sumatra; at least by such of the natives as visited frequently the ships, having fruits and other vegetables for sale; of whom some came in boats, of which both ends were alike made sharp, with a moving rudder to each, in order to be ready to steer backwards or forwards with equal ease; and others in canoes, so narrow as to have outriggers on the side to prevent their oversetting. Each of these canoes was managed by a single person, using an oar widened at both ends, to serve the purpose of paddling alternately on each side. The boats, as well as the canoes, were manned by a people who reside chiefly along the coasts of most of the islands in the Chinese seas, and are known by the general name of Malays, having a language and manners common to them all. The southern extremity of Sumatra is peopled, but very thinly, by a set of them who seem to lead an indolent and miserable life. Their dwellings near the shore were nothing more than sheds, in which they could not stand upright; their garments did not extend very much beyond the waist. Such a condition, indeed, which in most parts of Europe would imply the utmost wretchedness, is guarded by the climate from any actual suffering.

Several large tracts of land in that neighbourhood are 
covered only with a long coarse grass, growing wild upon Sumatra. a soil similar to that which produced the surrounding woods, and had therefore, probably, been cleared from trees by human industry; but, being now abandoned to spontaneous vegetation, seemed to imply a former population greater than the present. No degree of devastation or decline can be, indeed; surprising, if the inhabitants were in a constant state of hostility, which is to be inferred from the caution still subsisting amongst them, of never going, tho otherwise half naked, without being armed. A people that is poor is not apt to purchase what is superfluous; that is lazy, to labour for what is useless; or, in a hot climate, to carry what is cumbersome, without necessity. The weapon worn by them is a criss, or dagger, which, to render it still more fatal to those whom they may wound, they are said to steep in some poisonous juice of vegetables. They appeared generally of a low stature, brown complexion, with broad faces, large mouths, strong black hair, and very little beards, which, as it appears, they carefully pick out with pincers. Few of those who were seen by the passengers of the Lion and Hindostan had countenances which indicated any control of the mind over the sensual or vulgar passions.

Some degree of considerate civilization must, however, have directed their conduct in the following instance. Sir Erasmus Gower, previous to his departure 
Sumatra. for Batavia, caused a board to be nailed to a post, erected on the Sumatra beach, on which board were written directions for the Jackall, in case she should call there in his absence. On his return, he perceived that the board had been taken down; and the nails, which, it seems, were valuable to the Malays, carried away. And here a mere savage would have rested satisfied with the gratification of his own wants, and little solicitous about the object for which the board had been placed there by strangers; but the Malay, willing to reconcile that object with his own, took care, after removing the nails, to replace the board with wooden pegs; and it was found in this condition, inverted indeed, through ignorance of the language written on it. That letters are not absolutely unknown amongst them, was evident from the circumstance of some gentlemen of the Lion meeting, as they were walking through the woods, in a conspicuous path, two lines, probably in the Malay language, cut upon the thin bark of a bamboo, tied across a post.

One of the scamen of the Lion, who by chance was left alone on shore, with no inconsiderable quantity of linen to be washed, and who strolled unthinkingly to a neighbouring village, was hospitably treated and assisted; but such is the precariousness of the manners and principles of this people, that the very next day some of the Malay's murdered one of the most valuable artificers belonging to the Embassy, who went with a 
small bundle of linen in his hand to wash in a part of Sunvatra. the river a little above the shore. This man was as remarkable for the ingenuity of his mind as for a thonghtlessness of conduct, which rendered the former of little use to his own welfare. Beside being an cxcellent workman at his own trade of a joiner and cabinet-naker, he knew enough of several others to supply occasionally the want of those who had been bred to them; and was therefore highly useful in situations, like the present, where artificers must be scarce. He had seen better days; but the good humour and merry disposition, which he still retained, rendered him a favourite with the crew; and few deaths would have occasioned, so much as his, a detestation against the authors of it. This part of Sumatra was under a sort of subjection to the King of Bantam, who resided near the town of that name, on the opposite coast of Java. It was detemined to denounce the murder to him; for tho the perpetrators, or cause, or manner of it, could not be pointed out, yet the influence of his authority might produce a discovery leading to a punishment of the guilty. The Malays upon this part of the coast were fearful of reprisals upon them from the ships, and appeared no more; but they alleged that the fact was committed not by any of the inhabitants thereabouts, but by pirates, who sometimes stopped there for water. These pirates are Malays also, but chiefly from the more eastern islands, who sail in VOL. I. 
Sumatra. boats armed with four or six guns each, or more, and going together in numerous fleets, had of late taken several vessels, some belonging to the Dutch; and some to the English settlements in India, called country ships, as not trading out of Asia. Many of these had been obliged to be at the expence of hiring marines, or armed men, to be kept on board for their better protection against those pirates, whose vessels, being of a smaller size, and drawing little water, can use their oars in calms, and when they meet a superior force, often take shelter in the deep recesses in the south-east extremity of Sumatra; the whole of which is little more than a forest of mangroves, growing out of a salt morass.

The mangrove extends its roots, if they may be so termed, in a curve direction into the water from different parts of the trunk, forming arches to some distance, until they reach the bottom covered by the sea. To these roots, or inverted branches, oysters and other small shell-fish are found frequently to adhere; and this circumstance has given rise to the assertion, sometimes hazarded, of oysters growing upon trees. 'The baneful atmosphere and nightly logs, hanging upon such a marshysoil, must extend their influence to North Island, lying in its neighbourhood, and to the shipping at anchor near it. In the evening the clouds usually hung low, and narrowed the horizon, there being no general or rapid motion of the atmosphere to dispel them. 
The darkest of these clouds were charged with a large Sumatra. quantity of electric matter, which shewed itself in vivid sparks of lightning almost incessantly; but thunder was seldom heard, it bearing but a small proportion to the lightning that was seen. The phosphoric light perceived upon striking with the oar, or otherwise, upon the surface of the sea, was certainly occasioned by lucid particles spread upon it; and upon touching with the hand a wave, several of those particles remained perceptible some time upon the skin. They did not render the sea at night more brilliant than the myriads, on shore, of the fire-fly, called by entomologists lampyris; whose sparks are emitted from the two last circles of the abdomen, which appears to be affected as if by a kind of alternate respiration of the insect, the abdomen filling and darting light at every inspiration. The meteor called a falling star is supposed to be seldom observable within the tropics; but some were now seen here moving with much less celerity, and disappearing much less suddenly than is generally observed in the temperate zones. Tho Fahrenheit's thermometer seldom rose in the shade above eighty-five or eighty-six degrees, yet the air felt as if it came out of an oven; it produced inertness and debility even in the most healthy; and to this want of usual agility was, in some degree, attributed the misfortune, which happened now for the first time, of losing two of 
Java. the seamen, who fell from the masts or yards into the sea and were drowned.

The squadron determined to quit their present station, in hope of finding a better at Nicholas point, which is the most northerly of Java. They found it, in fact, free from swamps and fogs; the land and sea breezes constant, and the air generally clear, with very fine weather, while deluges of rain were observed to fall on the opposite shore. Tho the passage through the Straits towards China, or from it, be sometimes quicker, by keeping on the Sumatra side than on that of Java, the delay of a day or two is well compensated by the greater safety of the crew. The distance from North Island to Nicholas point is about eighteen miles, and the course north-west and south-east.

From Nicholas bay, proceeding easterly, the next is the bay of Bantam, famed formerly for being the principal rendezvous of the shipping from Europe in the East. Bantam was the great mart for pepper and other spices, from whence they were distributed to the rest of the work. The chief factory of the English, as well as Dutch, East India Company was settled there. The merchants of Arabial and Hindostan resorted to it. Its sovereigns were so desirous of encouraging trade, by giving security to foreign merchants against the violent and revengeful disposition of the natives, that the crime of 
murder was never pardoned when committed against a Java. stranger, but might be commuted by a foreigner for a fine to the relations of the deceased. This place flourished for a considerable time; but the Dutch having conquered the neighbouring province of Jacatra, where they since have built Batavia, and transferred their principal business to it; and the English laving removed to Hindostan and China, and trade, in other respects, having taken a new course, Bantam was reduced to a poor remnant of its former opulence and importance. Other circumstances have accelerated its decline. The bay is so choked up with daily accessions of new earth washed down from the mountains, as well as by coral shoals extending a considerable way to the eastward, that it is inaccessible, at present, to vessels of burden; even the party, who went there from the Lion in her pinnace, was obliged to remove into a canoe, in order to reach the town. A fire destroyed most of the houses there; and few have been since rebuilt. With the trade of Bantam the power of its sovereign declined. In his wars with other princes of Java he called in the assistance of the Dutch; and from that period he became, in fact, their captive. He resides in a palace, built in the European style, within a fort garrisoned by a detachment from Batavia, of which the commander takes his orders not from the King of Bantam, but from a Dutch chief or governor, who lives in another fort adjoining the town, and nearer 
to the sea side. His Bantamese majesty is allowed, however, to maintain a body of native troops, and has several small armedvessels, by means of which he maintains authority over some part of the south of Sumatra. His subjects are obliged to sell to him all the pepper they raise in either island, at a low price, which he is under contract with the Dutch todeliver to them at a small advance, and much under the marketable value of that commodity. The present king joins the spiritual to the temporal power, and is high priest of the religion of Mahomet; with which he mingles, indeed, some of the rites and superstitions of the aboriginal inhabitants of Java; adoring, for instance, the great banyan, or Indian fig tree, which is likewise held sacred in Hindostan, and under which religious rites might be conveniently performed; in like manner as all affairs of state are actually transacted by the Bantamese, under some shadowing tree, by moonlight. Upon application to his majesty, through the Dutch chief, he immediately dispatched two of his armed vessels to Sumatra, with orders to search for the perpetrators of the murder lately committed there; and some time after the ships had left this neighbourhood, intelligence was received that one of the guilty persons was discovered and executed.

In Nicholas bay was a convenient rivulet for watering; and at a litule distance from the shore a village, where bulfilocs, poultry, fruit, and other vegetables 
were to be purchased at a reasonable rate. Fresh proJava. visions were served daily to the Lion's crew; the decks and beams washed with vinegar, and an allowance of it given to the men; fires made to air the ship; and the ventilators kept constantiy at work. It was likewise found advantageous to send the invalids and convalescents from the ships ashore, to take air and exercise every day; the same was done at Angeree point, situated to the southward of point Nicholas, where the Dutch had a small battery of four guns, near a Malay village. Here indigo was manufactured from the leaf, growing in the neighbourhood. A bar at the mouth of the river at Angeree prevents the freedom of its current, and the lee of the indigo vats, thrown into it, must affect its good qualities; which circumstances render it inferior, as a watering place, to Nicholas bay.

The lowest order of the people on the coast did not appear to be obliged to perpetual labour, for the mere preservation of their existence; but had leisure, means, and disposition for amusements of different kinds. One of the Malay entertainments consists in the display of the various attitudes and postures of the same actor under different masks. By dint of exertions and of long practice, he had acquired such a power over the exterior muscles of his body, as to give to each an independent voluntary motion. Whenever his contortions were so uncommon as to excite the wonder, and obtain the applause of the spec- 
Java. tators, the performer immediately felt the effect of it, by the quantity of the small copper coin, in use among them, which came showering at his feet. The Malay. spectators were very numerous, and armed, as usual, with their crisses; their emotions, on observing any extraordinary feat upon the stage, were lively and instantaneous; and some of the Europeans seated amongst them were not altogether free from apprehension, lest the bustle were preparatory to a treacherous attack upon them.

Notwithstanding this ill disposition of the natives, the British seamen got soon into the habit of trafficking familiarly with them: some laid out a part of their dearly earned wages, in buying from them monkies, particularly the simia aygula of Linnæus, whose forehead always seems as if combed back in a toupee with fashionable care; and has cheeks capable of considerable distension, usually called alforges, in which he crams, for future use, such provisions as he cannot immediately consume. Others preferred a bird called a mino, which is not unlike a jackdaw in form and size; but remarkable for a yellow ruff or naked membrane round its neck ; and is supposed to be the aptest of all birds to emit and articulate sounds in initation of the human voice. The fish called by the sailors skip-jack, was sometimes an amusement to them. It is the blemins ocellatus of the naturalists, having eyes uncommonly prominent, and is seen frequently skipping mpon the surlace of the water. near the shore. 
No part of the Straits of Sunda abounds with esculent fish; and the Malays were driven often to feed on the Java. young or smaller species of the shark, which is too rank to be eaten by choice. The presence of sharks is supposed to frighten other fish away; tho no place supplies a greater quantity of the best kind than the road before the island of Amsterdam, where were also numerous and very large sharks. Another cause which often drives particular fish away, takes place in the Straits of Sundia; the frequency of vessels passing through, both European and Asiatic, of all sizes. But the adjoining lands on either side are sufficiently fertile to compensate for such a scarcity, by their ample produce. Not only the cultivated soil abundantly repays the labourer's toil, but much of the spontaneous growth comes forth at once, or easily is rendered, fit for the nourishment of man. The woors yield fruits, many of which, tho eatable, are, from the abundance of others, generally neglected. Some gentlemen of the Lion, without penetrating far from the shore, observed a fruit somewhat of the size and form of the pear, which was never offered for sale, but of which the natives ate; it grew immediately from every part of a tall stem, and not merely from the trunk and the thickest part of the principal branches, like the fruit of the cacao, or chocolate, or the jack and bread-fruit tree.

It was difficult to get far into the Java forests, from the quantity of underwood, and the vast number of vos, I. 
Java. creeping plants, which form a sort of net, supported by other trees, and are impassable without an instrument to cut them. Some of them were, likewise, of great strength. One trailed along the ground, in the manner of some of the convolvulus kind, with a stalk about an inch in diameter throughout, and of a length exceeding an hundred feet. The heat, for want of a current of air, was, sometimes, suffocating; and when near marshy ground, the mosquitoes or gnats were extremely tormenting. In some open spots were found webs of spiders, woven with threads of so strong a texture, as not easily to be divided without a cutting instrument; they secmed to render feasible the idea of him, who, in the southern provinces of Europe, proposed a manufacture from spiders' threads; which is so ridiculous to the eyes of those who have only viewed the flimsy webs such insects spin in England. The eye was often delighted with the sight of trees in superb blossom, and with the beautiful plumage of the birds; some of which, however, instead of charming with their notes, threw out a hissing sound, that gave the alarm of serpents about to dart their venom. In these excursions, the gentlemen seldom felt the inconvenience of rain. The dry season was set in; and the wind began to render it practicable for the ships to make some way, tho slowly, towards the Straits of Banca; and it was determined to attempt it without delay. 
Two ships from China arrived, indeed, in the middle Java. of April after a short passage, which implied, that the monsoon continued still unfavourable for going there, at least quickly. Those ships brought a confirmation of the former favourable accounts from China, and furnished a desirable opportunity of writing to Europe. Very soon afterwards the winds were so far shifted, as to encourage the Lion to set sail; but the current ran still to the south-west, often upwards of two miles an hour, while the breezes were so light, and so much interrupted by calms, that little advance was made; and the anchors were often lowered, to prevent the ships from being driven back, till the twenty-sixth of April, when the current began to change its direction to the east-south-east, and the next day to the north-east, half a mile an hour. Of the slight airs that blew, the utmost advantage was taken by crowding sail, as much as the Lion could be made to carry. On each side were studding-sails, spreading much beyond the hull; and above the main-top-gallant-royal sail, which is the fourth in number one above another from the deck, and diminishing from thence successively in size, was a fifth small sail of a triangular form, and from its great elevation, called a sky-scraper, which was not without effect. While the squadron was at anchor within three miles of the Brothers, which are two small islands covered with trees, and surrounded with coral reefs, an opportunity 
Straits of offered for determining, with accuracy, their latitude; Banca. which is five degrees eight minutes south, and their longitude, one hundred and six degrees four minutes east. About this place several whales were seen, for the first time since the slips had parted from the island of Amsterdam.

On the twenty-eighth, the hills on Banca island were perceived above the haze, which hid the lower grounds. The Glarence and Jackall were ordered to lead, and soon gave notice of the water's shoaling to three fathoms, which forced the Lion to come to anchor for a short time. The Hindostan got aground to the north-west of the small island of Lucipara. A large cable, or hawser, was immediately sent and fixed from her to the Lion, now under sail, and rowing boats were ordered to assist. In the efforts of the Lion to drag the Hindostan from the shoal, the cable, tho six inches in circumference, soon snapped; but not till the Hindostan was already loosened from the rock; and she got clear soon afterwards.

The eastern coast of Sumatra was constantly in sight; and the sea, to a certain distance, was rendered muddy and less salt, by the quantities of fresh water poured from the large rivers of that island, charged with eanth washed from the adjoining grounds. Detached pieces of the land were also seen sailing along, first driven by the force of the river's stream, and afterwards by the wind or current. They were literally floating islands, toru from 
the parent shores by the violence of the floods; and the roots of the trees or shrubs growing on them must have been closely matted and interwoven together, as well as loaded with much compact and heavy earth, to form a kind of ballast for steadying the drift, and keeping the stems of the trees in a perpendicular position.

On the thirtieth the squadron came to anchor near to the southernmost of the three Nanka isles, lying close to the western shore of the island of Banca. This latter island is noted throughout Asia for the same cause, its tin mines, to which England owed its celebrity in Europe in very ancient times, before its arts and arms had spread its fame throughout the globe. Banca lies opposite to the river Palambang, in the island of Sumatra, on which the sovereign of Banca, possessor also of the territory of Palambang, keeps his constant residence. He maintains his authority over his own subjects, and his independence of the neighbouring princes, in great measure, by the assistance of the Dutch, who have a settlement and troops at Palambang; and enjoy the benefit of a contract with the King of Banca for the tin which his subjects procure from thence; and which, like the King of Bantam, in regard to pepper, he compels the miners to deliver to him at a low price, and sells it to the Dutch at a small advance, purstiant to his contract. Those miners, from long practice, have arrived at much perfection in reducing the ore into metal, 
Straits of employing wood as fuel in their furnaces, and not fossil coal, or coak, which is seldom so free from sulphur as not to affect the malleability of the metal. It is sometimes preferred, therefore, to European tin, at the Canton market; and the profit upon it to the Dutch company, is supposed not to be less any year than one hundred and fifty thousand pounds.

Sir Erasmus Gower observed, that " it was very de" sirable for ships to stop at the Nanka isles, as wood "for fuel is conveniently procured from thence; and " the water thought preferable, for keeping, to any be"fore discovered by the squadron in those seas. It dis" charges itself from three small rills into a deep reser"voir. A cask was sunk, with holes in it, at a little " distance from the reservoir, into which the water was "conveyed perfectly pure and clear. At ligh water " the distance of rolling did not exceed ten yards. At " low water it was an hundred; but the rolling ground " was good, and what is material in that sultry climate, " the people employed in filling the casks were perfectly "shaded, as well as for a part of the rolling distance. "The tide rises and falls about eleven feet, and flows once " only in the twenty-four hours; at least during the ships" "stay there. The latitude of the road is two degrees "twenty-two minutes south, and the longitude one hun" clred and five degrees forty-one minutes east. This "place is perfectly sheltered lrom south-west by south 
"to the north-west; and there can be no high sea with "any wind, as the land is but at a short distance in the " open points."

On sailing in a boat round the largest of those small islands, a belt of trees was perceived, of a lighter green and younger growth, than the wood which it encircled; and on landing, this belt was found to have shot up from land yet moist, and scarcely recovered from the sea. In several spots throughout the island were discovered fragments of hæmatites, or blood stone, in a circular form, and including a hollow, partly lined with sand, which appeared to have succeeded to a liquid, at one time, boiling in these natural cauldrons. The sea was very shallow close to those petty islands, and heaps of stone mixed with iron ore were, in many places, seen just rising above the surface, without the least covering of vegetation, and as if, at no very remote period, vomited up by the force of subaqueous fire.

The squadron sailed from Nanka isles on the fourth of May. A shoal is described as leading almost from them to a rock, with little water over it, called Frederick Henry, from a ship of that name, which had been wrecked upon it some years ago. It was material to ascertain its exact position, that it might not be the occasion of a like misfortune to others; but the Clarence and Jackall brigs, and six boats were employed in seeking for it in vain; so that they must have been very un- 
Straits of lucky in the search, or the general accounts of its situa-

Banca. tion must have been defective. It is most likely that, tho those several vessels might have missed the rock, they would have touched the shoals, which are represented to extend from it to the neighbourhood of the Nanka isles, of which, however, they perceived no trace. The squadron continued its route, and crossed the line on the tenth of May, in longitude one hundred and five degrees forty-eight minutes east. Sir Erasmus mentions that "the observations at noon discovered that " a current had set the ships half a degree to the north" ward; which circumstance was to be expected from " the accounts given in Mr. Dumn's Directory." The same author adds, indeed, that at this season it sets likewise to the westward; but on making the land of Pulo Lingen, it was found that it had really set east-north-east twenty-seven miles in the twenty-four hours.

The equinoctial line crosses Pulo Lingen, which is a considerable island, remarkable for a mountain in its centre, terminating in a fork like Parnassus; but to which the unpoetical seamen bestow the name of asses' ears. Every day presented new islands to the view, displaying a vast variety in form, size, and colour. Some isolited, and some collected in clusters. Many were clothed with verdure; some had tall trees growing on them; others were mere rocks, the resort of innu- 
merable birds, and whitened with their dung. The weather was often, in this passage, squally, with thunder, lightning, and heavy rain. The squadron was frequently obliged to anchor. The sea was seldon deeper than eight fathoms. Fahrenheit's thermometer was from eighty-four to ninety degrees in the shade; and the heat sometimes so overcoming, that few, either of the passengers or crews, enjoyed perfect health. Some of the passengers removed from one ship to the other, by way of change, which was not entirely useless. Several of the seamen were afflicted with a dysentery, which, being contagious, was alarming to the rest, and left little hope of its being subdued, until the diseased were removed from the ships to some convenient shore, which might afford good air and fresh provisions.

Pulo, or island of, Condore had the advantage of convenient anchoring-places in either monsoon; and accordingly the squadron stopped there, on the seventeenth of May, in a spacious bay on the eastern side of the island; and came to anchor at the entrance of its southern extremity, as the water shoaled there to five fathoms and a half, occasioned by a bank which stretches across two-thirds of the entrance. It was found afterwards, that beyond the bank there is a safe passage to the inner part of the bay, the north of which is sheltered by a small island lying to the eastward. The whole of the bay is formed by four small islands, which approach vor. I. 
Pulo so nearly to each other, as to appear, from several points, Condore. to join. They all seem to be the rude fragments of primitive mountains, separated from the great continent in the lapse of time. The principal island is eleven or twelve miles in length, and about three in breadth. It is in the form of a crescent, and consists of a ridge of peaked hills. Its latitude, as calculated from a merilional observation, is eight degrees forty minutes north from the equator; and its longitude, according to a good chronometer, is one hundred and five degrees fifty-five minutes east from Greenwich. Mr. Jackson, who sounded in the bay, happened to land on one of these islets, where he found a turtle's nest upon the beach, containing several young just hatched, with a sort of placenta adhering to their bellies. Each of these young turtles, capable of growing to the weight of several hundred pounds, did not exceed a very few ounces now, and was but an inch and a half in size.

The English had a settlement on Condore until the beginning of the present century, when some Malay soldiers in their pay, in resentment for some unjustifiable treatment, murdered their superiors, with the exception of a very few who escaped off the island, where no Europeans have since resided. At the bottom of the bay was a village situated close to a fine sandy beach, with a long range of cocoa-nut trees before it, and it was defended from the north-east sea by a reef of coral rocks, 
within which was good anchorage for small vessels, and an easy landing for boats. A party went on shore with the precaution, however, of being armed, as large canoes were espied within the reef, which might have been Malay pirates. Several of the inhabitants came to the beach. and with the appearance of much urbanity of manners, welcomed them on shore; and conducted them to the house of their chief. It was a neat bamboo cabin, larger than the rest. The floor was elevated a few feet above the ground, and strewed with mats, on which were assembled as many men as the place could hold. It was apparently on the occasion of some festival, or pleasurable meeting. There was in one of the apartments, an altar decorated with images; and the partitions hung with figures of monstrous deities; but the countenances and deportment of the people conveyed no idea of religious awe, and no person was seen in the posture of prayer or adoration. A few spears stood against the wall with their points downwards, together with some matchlocks and a swivel gun. The dress of those people was composed chiefly of blue cotton, worn loosely about them; and their flat faces and little eyes, denoted a Ghinese origin or relation. Several long slips of paper, hanging from the ceiling, were covered with columns of Chinese writing. One of the missionaries, who was of the party, could not, however, in any degree under. stand their conversation; but when the words were 
Pulo written, they instantly became intelligible to him; tho Condore. what is spoken in China, yet the characters were all Chinese; and the fact was clearly ascertained on this occasion, that those characters have an equal advantage with Arabic numbers, of which the figures convey the same meaning wherever known, whereas the letters of other languages denote not things, but elementary sounds, which, combined variously together, form words, or more complicited sounds, conveying different ideas in different languages, tho the form of their alphabet be the same.

The inhabitants of Pulo Condore were, it seems, Cochin-Ghinese, with their descendants, who fled from their own country, in consequence of their attachment to one of its sovereigns, dethroned by several of his own subjects. It was proposed to purchase provisions here; and the people promised to have the specified quantity ready, if possible, the next day, when it was intended, if the weather should be farourable, to land the invalids. The next morning was fair in the beginning; and a party of pleasure was made from the Hindostan to a small island close to Pulo Condore. They were scarcely arrived upon it when the weather began to lower; and the boat set off on its return, in order to reach the ship before the impending storm should begin. But it overtook them before they got hall-way. One of the company 
was a boy, whose father had been prevented by indisposition from being of the party, and was now anxiously looking, from the deck of the Iindostan, for the return of the boat. He perceived it sometimes above the waves; and it sometimes disappeared behind them. The most indifferent spectator, if any could be indifferent, doubted whether the boat must not be overwhelmed in such a sea, as now suddenly was raised; while the distracted parent was ardently wishing to be in the boat, as if his presence there conld have allayed the tempest. The cockswain, or helmsman of the boat, guided it, however, with such address, keeping her bow steadily to the approaching wave, which otherwise must have filled and sunk her, that she reached the ship; then, however, rolling so deeply, that the boat had again a narrow escape, from being sunk or dashed to pieces against the greater vessel's sides.

As soon as the weather became fair, messengers were dispatched on shore, to receive, and pay for, the provisions promised. When they arrived at the village, they were astonished to find it abandoned. The houses were left open; and none of the effects, except some arms, that had, on the first visit, been perceived within them, or even of the poultry feeding about the doors, were taken away. In the principal cabin a paper was found, in the Chinese language, of which the literal translation purported, as nearly as it could be made, that "the people 
Pulo "of the island were few in number, and very poor, yet Condore. "honest, and incapable of doing mischief; but felt " much terror at the arrival of such great ships, and " powerful persons; especially as not being able to " satisfy their wants in regard to the quantity of cattle, " and other provisions, of which the poor inhabitants " of Pulo Condore had scarcely any to supply, and " consequently could not give the expected satisfaction. "They therefore, through dread and apprehension, "resolved to $\mathrm{fly}$, to preserve their lives. That they " supplicate the great people to have pity on them; that " they left all they had behind them, and only requested " that their cabins might not be burnt; and conclude "by prostrating themselves to the great people a hun" dred times."

The writers of this letter had probably received ill treatment from other strangers. It was determined that they should not continue to think ill of all who came to visit them. On their return they were, perhaps, as much surprised to find their houses still entire, as their visitors had been, who found they were deserted. Nothing was disturbed; and a small present, likely to be acceptable to the chief, was left for him in the principal dwelling, with a Chinese letter, signifying that "the ships and " people were English, who called merely for refresh" ment, and on fair terms of purchase, without any ill " intention; being a civilized nation, endowed with 
"principles of humanity, which did not allow them to "plunder or injure others, who happened to be weaker " or fewer than themselves." It was not likely that this letter would be read while the ships continued in the bay, during which time they who fled would, no doubt, be fearful to return. It was, beside, advisable to hasten wherever the invalids might meet on shore with the comforts which Pulo Condore, it seems, could not afford. The signal was given for weighing anchor on the eighteenth of May.

In all large ships the anchor is raised by means of a capstan, or machine fixed in the keel or bottom of the ship, and rising above the upper deck, where it has sockets made in its sides, breast-high, for the occasional insertion of wooden bars, with which the men turn the capstan round, coiling about it at the same time a rope, called a messenger, as connecting the capstan with the great cable, bent to the anchor then in use. Upon the present occasion the weather happened to be again squally, and the ground being tough in which the Hindostan lay, the anchor was difficult to raise, and therefore several soldiers of the Embassador's guard, who were in the Hindostan, assisted the seamen in pressing upon the bars. In the midst of their efforts the messenger happened suddenly to snap. The anchor, partly hauled up, fell back with increased velocity, and whirled the capstan so rapidly about, that the bars, 
Pulo each about six inches square, and sixteen feet long; Condore. shot, in all directions, violently from their sockets; prostrating every man within their reach with irresistible force. One of the bars made its way across the cuddy, or dining parlour, to the door of the great cabin. The quarter-deck was streved with people groaning with their wounds. Most of the crew had been employed that day upon the capstan. How many might be killed or maimed could not instantly be ascertained; but such was the impression on the captain's mind, who was viewing the operation from the poop, that tho there then happened to be three medical gentlemen on board, he cried out that they should first attend to the fractured limbs, leaving other accidents to be inspected afterwards. The consternation was indeed greater than on a day of battle, for which people have generally some previous preparation, and expect to derive honour or profit in compensation for the danger. No man, however, by this disaster, lost his life; many of the seamen accustomed to the manocuvres on ship-board, and possibly aware of the accidents which attend them sometimes, were quick enough to avoid being hurt; but few escaped among the soldicrs. Particular care was immediately taken of such as had been struck; and the ten men whose limbs were broken, or who otherwise were wounded, gradually recovered. The accident detained, for some tinc, the Hindostin at anchor, till the squall 
increasing, the cable parted from the anchor, which thus Pulo was lost, and the ship was driven out to sea. The wind Condore. blew hard; and it was with difficulty that the brigs stood out the gale. As soon as it was over, in the evening of the eighteenth of May, the whole squadron steered away to the northward. 


\section{GHAPTER VIII.}

COCHIN-CHINA.

Passage to $\quad \mathrm{IAD}_{\mathrm{D}}$ even the south-west monsoon already set in Turon Bay. regularly, and favourably for a passage immediately to the northern parts of China, it would not have been yet advisable to take advantage of $i t$, as the debilitated state of the Lion's crew, and the contagious disorder that was spread amongst them, rendered it, previously, necessary to seek the first safe and convenient place for removing the sick ashore, wherever fresh provisions could be procured, and where they could breathe a dry and uncontaminated atmosphere. It was no slight trial of the constitutions of men, born in a cold climate, to have been thrice already, in the course of a few preceding months, placed under the sun's vertical rays. Their stay at Batavia, tho short, had likewise an evil influence upon their health; and the eastern shore of Sumatra, to the noxious vipours of which they had occasionally been cxposed in some part of the Straits of Sunda, as well as in passing through those of Banca, was, perhaps, not less injurious. Beside the dysentery, which it was difficult to prevent from spreading through a crowded ship, several of the people were afllicted with diseases of the 
liver. Others, without any previous indication of com- Pasage to plaint, were seized with violent spasms, from which it 'Turon Bay. was difficult to recover them; and the heat was so oppressive, at night as well as in the day, that the men at work between decks, particularly in the spirit rooms, were known sometimes to faint away, tho the ventilators were constantly kept in use to introduce fresh air. Out of three hundred and fifty men on board the Lion, one hundred and twenty were, at times, in the list of patients.

From the reports of former voyages, relative to the different places not very distant from Pulo Condore, Turon bay in Cochin-china promised the most advantages, as to safety for the ships, and shelter and provisions for the men. The squadron steering for that bay, came, on the evening of its departure from Pulo Condore, within sight of the southern extremity of that part of the great continent which may, properly, be called Chinese; near to which extremity lies Cochin-china. The first small kingdom, or territory, from the southemmost point being called Cambodia; the second Tsiompa; and the third Cochin-china. It is recorded to have formed, anciently, a part of the Chinese empire; but on the Mongul invasion of China, from Tartary, in the thirteenth century, the Chinese governor of the southern peninsula, containing Tung-quin to the northward, and Tsiompa and Cambodia to the southward, of Cochin- 
Passage to china, took the opportunity of setting up the standard Turon Bay. quin. In process of time, the Tung-quinese governor of Cochin-china imitated the example that had been set by the ancestor of his sovereign, and erected, likewise, his government into a kingdom. But both he and his former master continued to acknowledge, at least, a nominal vassalage to the Chinese empire; and, occasionally, paid homage at the court of Pekin. Even this slight connection with China, rendered it more interesting to the persons belonging to the present Embassy.

The squadron did not come within view of any part of Cambodia ; but in a manuscript account of a voyage to that country, made in 1778 , and which appears to have been accurately drawn up, it is mentioned, that "the " point of Cambodia, as well as the whole coast from " thence to the western branch of the great Cambodia " river, is covered with underwood, and exceedingly "low. The sea is so shallow, that, at the distance of " five or six miles from the shore, the water was seldom " deeper than four fathoms; and nothing much larger " than a boat, could approach within a couple of miles." It is not unworthy notice, by what slow gradations the land, in this southern extremity of Asia, sinks into the deep, in the same manner as does the southern extremity of the island of Sumatra ; itself, perhaps, a detached portion of the same great continent. 
Tsiompa, more elevated from the sea than Cambodia, Prsage to was seen by the squadron on the nineteenth of May, as $\stackrel{\text { Turon Bay. }}{=}$ well as Tiger island near it, and, the next day, two islands called Pulo Cambir de Terre, and Pulo Cecir de Mer. Tsiompa presented, to the naked eye, the prospect of a fine and well cultivated country, gently sloping from the sea, and beautifully diversified with pasture grounds and fields of corn ; but, on examining more attentively, by the help of telescopes, all that pleasing and luxuriant appearance vanished; leaving only, in its room, immense tracts of pale and yellow sand, the smooth surfaces of which were interrupted by ledges of dark rocks, raising their naked heads to a considerable height. The elevated ridges shewed, in various places, alternate masses of white and black, like the streaked skins of tigers, shining conspicuously when the sun's beams struck upon those shores. The sea, near to them, was so translucent, that the eye could easily discern, from the stern gallery, the bottom of the rudder.

In twelve degrees fifty minutes north latitude, was a cape called Varella, behind which a mountain rose, remarkable for having a high rock, like a tower, on its summit. To the northward of this rock lay Quin-nong, or Chin-chin bay, much frequented by the vessels of the country. According to the manuscript last quoted, "it " is an excellent harbour, where vessels may be shel- 


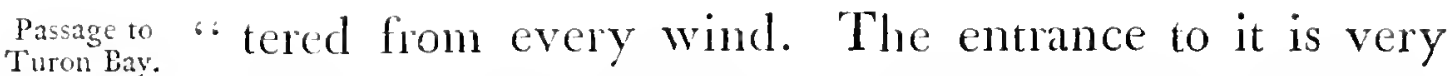
"narrow; but the want of a sufficient depth of water, " must oblige ships of large burden to wait till high "water, to get in. It lies in thirteen degrees fifty-two "minutes north latitude."

On the twenty-second of May, Pulo Canton, otherwise called Pulo Ratan, came in sight, bearing the semblance of two islands, at some clistance, being high at both extremes and low in the middle. It was the only island lately seen, on which there was much appearance of cultivation. A north-west current drove the squadron nearer, than was intended, to that ishand, there happening at the moment to be little wind.

The ships had been, now some time, abreast of the kingdom of Cochin-china. The passage between its shore, and a vast multitude of small islands and rocks, called the Paracels, forming a lengthened cluster lying north and south for near four hundred miles, was not without some peril; and required no inconsiderable caution, to guard against the effect of easterly currents, which drive towards the rocks in calms; as well as, in the opposite case, against the violent tempests, which, in these seas, are called typhoons, as they are hurricanes in the Atlantic; both resembling cach other in the cxtreme violence of the wind, and in the sudden shifting of its direction. Some previous appearances of the weather alenote the probable approach of those typhoons to 
the attentive navigator; and give him time to prepare pasage to his ship against their fury. These prognostics were observed to take place, in some degree, on the evening of the twenty-third of May. An uncommon redness of the sky at sunset, and a hazy atmosphere succeeded to a fine clear day. The quicksilver fell suddenly in the barometer. After the sun had descended below the horizon, a thick black cloud arose out of the north-east quarter, tinged, in parts, with a deep fiery red colour, which was luminous round the edges. Presently afterwards the whole horizon was covered over with clouds; and the storm was expected, momently, to burst. The precaution was, consequently, taken of lowering the ship's masts and yards, and spreading very little sail, in order that the wind should have less to act upon; and every thing was, in the seamau's phrase, made snug. The clouds, however, after some time, dispersed. The quicksilver ascended after a few violent squalls, and the next morning ushered in fine weather; and shewed, at a distance, an opening in the land, which was conjectured to be Turon bay, with an island to the southward of it, called Cham Callao or Campello.

Many canoes were seen fishing between the ships and land. The nearest were hailed, in order to get, from among the fishermen, some one who might pilot the squadron into the bay. But these not caring to approach strange vessels, immediately made sail and scudded 
Passage to Turon Bay.

away directly before the wind. One of those canoes was, however, at length overtaken by a boat, dispatched from the Hindostan; and a fisherman was conveyed on board. He was an old man, with sunken eyes, his head thinly covered with a few grey straggling hairs, and a countenance haggard with age and terror. He left, in his boat, two young men, probably his sons; for, as he was extremely apprehensive of intended mischief, when the messenger from the ship insisted upon taking some one person from the canoe, he preferred freeing them from the danger, tho by exposing himself to it. When he got to the Hindostan, he appeared as if petrified at the sight of the spacious deck, the great guns, the number of people, and above all, at the height of the masts, from which he could scarcely withdraw his eye, as if fearful lest they should fall upon him. Of the Chinese on board, none could render themselves intelligible to this poor man, or understand a word of what he uttered. Questions were written in the Chinese character before him; but he made signs to testify that he knew not how to read or write. The sound of the words Cochin-china and Turon, were perfectly unknown to him; these names not having been given by the inhabitants of the country; but by early European navigators and geographers. He repeatedly threw himself upon his knees and wept, notwithstanding the pains taken to soothe and satisfy him: and when, in the working and tacking 
of the ship, her liead happened to be turned from the land, his alarms increased, and he fell into an agony of grief, imagining there was an intention to quit the coast, and carry him off for ever. Victuals were offered to him, of which he ate reluctantly and sparingly; but when a few Spanish dollars were put into his hands, he shewed he had a knowledge of their value, by carefully wrapping them up in a corner of his tattered garments. After repeated efforts, he was made, at length, to comprehend the object for which he had been brought on board; and, being now somewhat tranquillized, he pointed out the entrance into the bay of Turon, which is not readily perceived by strangers. The only chart, known to have been published, of that part of the coast, was merely a rough sketch, taken by some officers of the Admiral Pocock Indiaman, that had been accidentally driven there, by stress of weather, many years ago; but it gives no information or instruction how to enter into the bay, and was afterwards found to be erroneous in many respects.

In making this part of the coast, from the southward, the most remarkable object, that attracts attention, is a group of massy marble rocks, that look like an enormous castle, appearing to be insulated; and not unlike, tho much larger than, the rock of Dunbarton castle, rising perpendicularly from the Clyde, in Scotland. A few miles to the northward of this Cochin-chinese pile of voL. I. 
Passage to rocks, is a bold and elevated promontory, surmounted by $\stackrel{\text { Turon Bay. }}{=}$ two peaks, on much higher than the other. To a stranger, the entrance into Turon bay would appear to lie between the mass of rocks first mentioned, and this elevated promontory; but these objects are joined, in fact, by a low and narrow isthmus. The entrance to the bay is round the north-easternmost point of this peninsular promontory, which was now called, by the squadron, Lion point; not only in compliment to his Majesty's ship, but on account of some faint or fancied resemblance, which a rocky bluff, jutting from the point, bears to a lion conchant, when seen at a little distance.

The Cochin-chinese fisherman, by way of describing where the Hindostan ought to anchor, bent his left arm to represent the mountains which overlooked the bay, and dropped down the fore-finger of his right hand, to mark the relative proper spot for anchoring; but tornadoes or sudden squalls of wind from different points, and accompanied by lightning and thunder, drove the ships again to sea; nor were they able, safely, to come to an anchor, within the bay, till the twenty-sixth of May. The old Cochin-chinese was now dismissed, with a compensation for his fright, as well as for his services. When he was carried to the shore, he jumped from the boat almost with the alertness of youth, and, hastening away, came never, afterwards, ncar the ships.

Sir Erasmus Gower "moored the Lion in seven 
"fathoms water, the north-west point of the bay bear-

" ing north-east by north, an island in the mouth of the

"bay, north, the watering place on the peninsula, east

" by north; Campello isle, which is seen over the isth-

" mus, south-east by east, a river on which the town of

"Turon is situated, sonth-south-east half east. The pen-

" insula bore some resemblance to Gibraltar, which

" name was henceforward given to it by the squadron.

"The channel into the bay is round the north-east end

"of Gibraltar, having a large lump of an island to the " north. All the coast is safe to approach, shoaling the "water gradually from twenty to seven fathoms."

The first consideration, after having come to anchor, was to seek for a place to put the sick and invalids ashore. A spot was quickly found under Gibraltar hill, near the Lion's station, where the ground was perfectly dry, the neighbourhood free from swamps, and a clear stream of water running behind the tents which were pitched for the men. Pains were taken, after their departure, to purify the ship from all traces of contagion ; and a message was about to be sent, at the same time, to the town of Turon, which lay upon a river falling into the bay, to announce the occasion of the squadron's stopping in it, and to request a supply of fresh provisions at reasonable and customary rates. But the Lion was scarcely at anchor, before an officer from shore came on board, for the purpose of learning every parti- 
Cochin. cular relative to the squadron, the appearance of which, china. it seems, had spread alarm. The vessels that usually resorted there, were either junks from different parts of China, or trading vessels from Macao of an European make, but small, and without any warlike appearance. Of the former there were none actually in the bay; and of the latter one brig only. Ships like the Lion and Hindostan were seldom seen there. Beside these, and the Jackall and Clarence which attended them, a fifth vessel soon followed into Turon bay. She was under Genoese colours ; but, chiefly, manned by Englishmen. She had found the squadron in the straits of Sunda, and kept company with it, occasionally, afterwards.

The whole appeared particularly formidable to the people on shore, from a cause which the commander of the Macao brig explained. He mentioned that Turon, with a considerable part of the kingdom of Cochinchina, was then subject to a young prince, nephew of an usurper, whose antagonist, the descendant of the former sovereigns of the country, was still in possession of sonre of the southern districts of the kingdom, and was in daily hope of such succours, from Europe, as might enable him to recover all the possessions of his ancestors. His family had, occasionally, shewn kindness to European missionaries, and tolerated the exercise of the Christian religion among their subjects. The principal of those missionaries, who had been diguified with the 
title of Bishop by his holiness the Pope, was atterwards sent by his Cochin-chinese majesty as his embassador to the court of France, where an uncommon degree of interest was taken in the young prince of Cochin-china, whom the bishop had conducted to Europe with him. Succour was promised for the re-establishment of his house; and in case of success, benefit would, no doubt, have accrued to the commerce of the French. Measures were in preparation for sending out effectual aid, when the extraordinary events at home put an end to the expedition, and deprived the generous monarch, who had ordered it, of the power of assisting either others or himself. Some individuals, however, from France did join the legitimate king of Cochin-china, and gave liopes of further assistance. These hopes were often repeated by way of encouragement to his partisans; and his enemies, in possession of Turon bay, began to be apprehensive lest the squadron now at anchor in it, should, in fact, be come with hostile intentions against them.

But a communication was soon opened between the officer who came on board and the Chinese interpreters, in the same manner as had been effected at Pulo Condore, by means of the written characters of the Chinese language. The neutral and pacific disposition of the squadron was announced, its general object declared, and a request made for the supply of its immediate wants. For the first two or three days, however, very little was 
cochin- obtained. Few boats approached the ships with provichina. sions for sale, tho it be usual to do so, in great numbers, in most harbours. The market on shore was very scantily supplied; and extravagant prices demanded for every article. It was obvious that the governing magistrate of the place, who, it seems, had instantly dispatched a messenger to the capital, with an account of the arrival of the squadron, and for instructions how to act, had, in the mean time, checked the sale of all provisions.

A person of some rank soon arrived at Turon, who delivered very handsome compliments from his master to the Embassador. He came in a large decked galley, of a light and sharp construction, formed for quick sailing. The rowers, who were very numerous, rowed in an erect posture, and pushed the oars from them, making short and frequent strokes. A state cabin was erected, on the middle of the deck, painted in lively colours; each end of the galley was decorated with streamers of different colours and figures. The state cabin was, on the outside, surrounded with spears, and various cnsigns of authority. The principal officer, who came in her, was dressed in loose robes of silk, had the polished manness of cullivated socicty, and was attended by a Chinese interpreter. His galley was followed by nine boats, calculated for carrying burdens, and full of rice and other provisions, animal and vegetable, as presents, for 
the use of the passengers and crews. From that moment the markets were plentifully supplied, and the prices reasonable. The governor of the district came, also, on board to pay his respects, invited the Embassador and his suite ashore, and proposed to keep an open table for them constantly. Every mark of attention was shewn henceforward; and every effort made to cultivate the best understanding with his Excellency and the squadron.

Overtures were made for the purchase of arms and ammunition; and it was easy to perceive that any assistance given to the cause of the prince, then reigning at Turon, as well as at the capital and northern parts of the kingdom, would have been willingly purchased on any terms. His situation, indeed, was very far from being secure. Beside the province of Donai, or southern part of Cochin-china, which had reverted to the ancient family of its sovereigns, Quin-nong, or the middle province of the kingdom, was in the hands of the late usurper of the whole. He had entrusted to his younger brother the care of his conquests to the northward; but the latter availed himself of his command, first to invade the neighbouring kingdom of Tung-quin, with complete success, notwithstanding the assistance given to the latter by the Chinese, and then declared himself sovereign both of Tung-quin and Cochin-china, intending to wrest, for his own use, from his elder brother, whatever the latter 
Cochin- still possessed of that kingdom, as well as whatever part china. had been recovered by the lawful sovereign. This new usurper was an able warrior, and had formed vast projects of conquest, even of some Chinese provinces; he was one of those politicians to whom all means are equally eligible that can contribute to their successes. He died in the midst of them in September, 1792. Of his sons he left the eldest, who was illegitimate, in the government of Tung-quin. The youngest, who was his legitimate offspring by a Tung-quinese princess, was at Turon at the time of his father's death. He instantly assumed the reins of government, as lawful successor to his father, while his elder, but illegitimate brother, retained possession of Tung-quin, and claimed a right to the whole of his father's conquests.

The state of rebellion or civil warfare in Cochinchina had begun upwards of twenty years before, in the course of which so very many of the combatants were slain, the country was so exhausted, and the surviving parties so balanced, that, at this time, no considerable enterprize was undertaken by any of them; tho each was busy in preparing new plans for the support of himself and the overthrow of his enemies. In the mean time the people began, in some degree, to breathe; but had the kingdom even been more settled, the Embassador did not think it would have been proper to enter into any sort of negotiation, or even to present the 
credential letters, with which he had been entrusted for that kingdom, before he had delivered, in the first instance, those he had in charge for the Emperor of China. His Excellency, therefore, determined to confine himself to messages of compliment and respect, and to a return of presents for those he had so seasonably received for the use of the squadron. An uninterrupted communication was continned to be maintained with the people of Turon; but not without some marks of mistrust, and consequent watchfulness, on both sides.

The bay of Turon was found to deserve, more properly, the name of harbour. Its entrance is neither so narrow, nor so capable of being defended, as the port of Rio de Janeiro, described in a former chapter; nor, within, is it so deep or spacious; but it is, nevertheless, among the largest, as well as safest, harbours known. It is deeply scolloped or indented, so as to afford perfect shelter, in some or other of its inlets, from whatever point of the compass the most violent wind may blow. The bottom is mud, and the anchorage sale throughout. In common weather, ships may so lie as to have the advantage of the sea wind, coming in at the harbour's mouth, and over the narrow isthmus already mentioned, from the hours of three or four in the morning, to the same hours in the afternoon. The land wind succeds very quickly, and continues almost the rest of the twenty-four hours. The ships have all the benefit of vor. I. 
Cochin- its coolness as it descends from the mountains, without passing over sands; nor is it contaminated by blowing across marshes. A small island, within the harbour, is nearly surrounded with such deep water as to admit of vessels of all kinds lying close to it, in order to heave down and be refitted. The sea is smooth throughout the harbour. Between the mountains, overhanging it, are vallies in which rice is cultivated, and buffaloes are reared, with much success.

The liarbour abounds with fish. In some of the boats the fisherman, his wife, and children, continue with him, sheltered under a circular roof instead of a flat deck. Round the young children's necks are tied broad pieces of gourd or calibash, to keep their bodies afloat and their heads from sinking, in case of their falling nerboard. As often as the fishermen come on shore, they implore their deities for the safety of their families, and their success in fishing, by erecting small altars to them among the branches of large trees, or other elevated places, on which they make offerings of rice, sugar, and other victuals, and burn short pieces of odorous and consectated wood.

At the sonthern extremity of the harbour is the mouth of the river which leads to Turon town. On the point, which separates the river from that harbour, is a watchtower, consisting only of four very high pillars of wood, over which a slight rool is laid, and a floor is fixed upon 
cross posts into the pillars towards their upper ends. To this floor the watchman ascends by a long ladder, and there he can readily see, through the harbour's mouth, any vessels to the northward, and those which are to the southward over the isthmus. Near the watch-tower is an office where the boats and small vessels, going into the river, are stopped to be examined. The river is about two hundred yards in width, and its current into the bay is sufficiently strong to work itself a channel in the bank of sand, accumulated at its entrance into the harbour. On each side of this channel the sand is raised so high as, at low water, to be uncovered by the sea; and on this sand was seen, for the first time throughout the present voyage, that celebrated bird, vulgarly called the pelican of the wilderness, whose gullet, bill, and wings, seem to be much beyond the proportionate size of its body, which is, however, equal to that of the largest turkey. It frequents only waters where fish abound; of which its presence argues plenty. The depth of the water in the river was upwards of two fathoms. One Chinese junk, and several Cochin-chinese large boats were at anchor in the river, and others passing through it. The land on its western bank, on which the town of Turon lay, about a mile above its mouth, sloped down to the water's edge; and the naked infants, of two years old and upwards, came, from the houses built among the shrubbery growing upon its 
Cochin- borders, and played and swam like ducklings in the water.

Turon, to which, as well as to the river and harbour, the natives give the name of Han-sán, was little better than a village, but is said to have been, during the peace and prosperity of the country, a more considerable place. The houses, which were low and chiefly built of bamboo, and covered with rushes, or the straw of rice, were, except about the market-place, interspersed with trees. Many of the best buildings are in the centre of gardens planted with the areca-nut tree, and various other pleasing or useful shrubs. Behind the town were groves of oranges, limes, plantains, and areca-nut trees, in the midst of some of which were houses, and in others only remains of buildings. The opposite side of the river was divided into fields, surrounded by fences, and cultivated with tobacco, rice, and sugar-canes. The market in the town was plentifully supplied with all the vegetable produce of tropical climates, as well as with large quantities of poultry, particularly ducks; and, among other fowls, the black-bellied darter, a kind of bird so called from its supposed propensity to dart its sharp and long beak at any shining objects near it, particularly into any eye turned towards it; on this account those animals are brought to the Turon market with their eyelids sewn together, to deprive them of the opportumity of discerning the eyes of those who come to purchase them. 
There were no shambles or places containing the separated parts of animals killed for sale. At an entertainment, however, given by the chief of the place to a party from the ships, many of the dishes, or rather bowls, upon the table, were filled with pork and beef, cut into small square morsels, and dressed with a variety of savoury sauces; other bowls contained stewed fish, fowls, and ducks; and many had fruits and sweetmeats. The number of bowls, piled in three rows, one above the other, exceeded certainly an hundred. Before each person were placed boiled rice to serve instead of bread; and two porcupine quills, by way of a knife and fork. The spoons were made of porcelain, somewhat in the form of small shovels. After dinner an ardent spirit, made from rice, was served in small cups around. Wine does not seem to be in use, or known; tho vines are said to grow spontaneously in the mountains. Had the art of stopping the fermentation of vegetable juices, before they passed from the vinous state, been understood by them, it is probable that it would be, in most instances, preferred to distilled liquor, to the use of which this people seem to be much addicted. More of this Cochin-chinese spirit, not ill resembling what is called, by the Irish, whiskey, was drank by the host than by his guests; tho the former, by way of setting a good example, filled his cup to the brim, in a true European style of joviality, and, after drinking, turned up his cup, to shew he had emptied it 
Cochin- to the bottom. He afterwards accompanied the gentlechina. men in a short walk, and conducted them to an occasional theatre, where a comedy had been ordered by him, upon the occasion, of which the mirth was excited, chiefly, as well as could be inferred from the gestures of the actors, by the peevishmess of a passionate old man, and the humours of a clown, who appeared to have no small degree of merit in his way. The place was surrounded with crowds of people, and many of them perched upon the bouglis of adjoining trees, from whence they might see, at an open part of the building, the spectators within doors, about whom they were, in this instance, more curious than about the actors upon the stage.

As the gentlemen were returning from this entertainment, they were requested, by signs, to stop while an aged lady, with some difficulty, walked from lyer house towards them. She had heard that Europeans were passing by; and, not having before seen any, seemed anxious to take the opportunity, which might not offer again in her time. She approached them with looks of eagcr curiosity, but with much gentleness of manners, and a conntenance implying a willingness to apologize for the lreedom she took, to stop and gaze at them. She observed, with great attention, their figures, clress, and countenances, and appeared perfectly to enjoy a spectacks so new to hes. She, at lenglh, retired, signifying 
her thanks to the gentlemen for their complaisance, and with all the marks of satisfaction, at being gratified in one of the most ardent wishes remaining in her mind.

Those gentlemen's own attention was soon afterwards arrested, by a singular instance of agility, in some Cochinchinese young men. Seven or eight of them, standing in a circle, were engaged in a game of shittlecock. They had in their hands no battledores. They did not employ the hand or arm, any way, in striking it. But, after taking a short race, and springing from the floor, they met the descending shittlecock with the sole of the foot, and drove it up again, with force, high into the air. It was, thus, kept up a considerable time; the players seldom missing their stroke, or failing to give it the direction they intended. The shittlecock was made of a piece of dried skin rolled round, and bound with strings. Into this skin were inserted three long feathers spreading out at top, but so near to each other, where they were stuck into the skin, as to pass through the holes, little nore than a quarter of an inch square, which are always made in the centre of Cochin-chinese copper coins. Two or three of these served as a weight at the bottum of the shittlecock, and their sound gave notice to the players, when it was approaching to them. This curious mode of exercise is represented in Plate No. 14.

It is not at sportive games alone, that these ingenious and active people apply their feet as others do their 
Cochin- hands. The lower, and, at least, some of other ranks, chind. generally, go barefooted; and their toes have, thus, freer motion, and more contractile power than those which are always inclosed in shoes; and serve, jointly with the foot, as auxiliaries to the hand and fingers in the exercise of many trades, particularly that of boatbuilders. The boats, commonly in use among them, consist of five planks only, joined together without ribs or timbers of any kind. Those planks are bent to the proper shape, by being exposed some time to a flame of fire; they are brought to a line at each end, and the edges are joined together with wooden pins, and stitched with bamboo split into flexile threads; and the seams afterwards smeared with a paste made with quick-lime, from sea shells, and water. Others are made of wicker work, smeared all over and rendered water-tight by the same composition as is used for the former. The owners affect to paint eyes upon the heads of all those boats, as if to denote the vigilance requisite in the conduct of them. They are remarkable for standing the sudden shock of violent waves, as well as for being stiff upon the water, and sailing expeditiously. 'The boat belonging to the chief of the district, was built upon the same plan, but on a larger scale, had a carved and gilt head, bearing some resemblance to that of a tiger; and a stern ornamented with sculpture, and painted with a variety of designs in lively colours. In these boats the princi- 
pal sitters are generally at the stem, instead of being cochin. near the stern, as is the custom in Europe.

The Cochin-chinese seemed sufficiently dexterous and attentive, tho with scarcely any principles of science, to make, on any substances which promised to be of use or comfort to them in private life, such trials and experiments, as were likely to produce beneficial results. In the culture of their lands, and in the few manufactures exercised amongst them, they were not behind nations

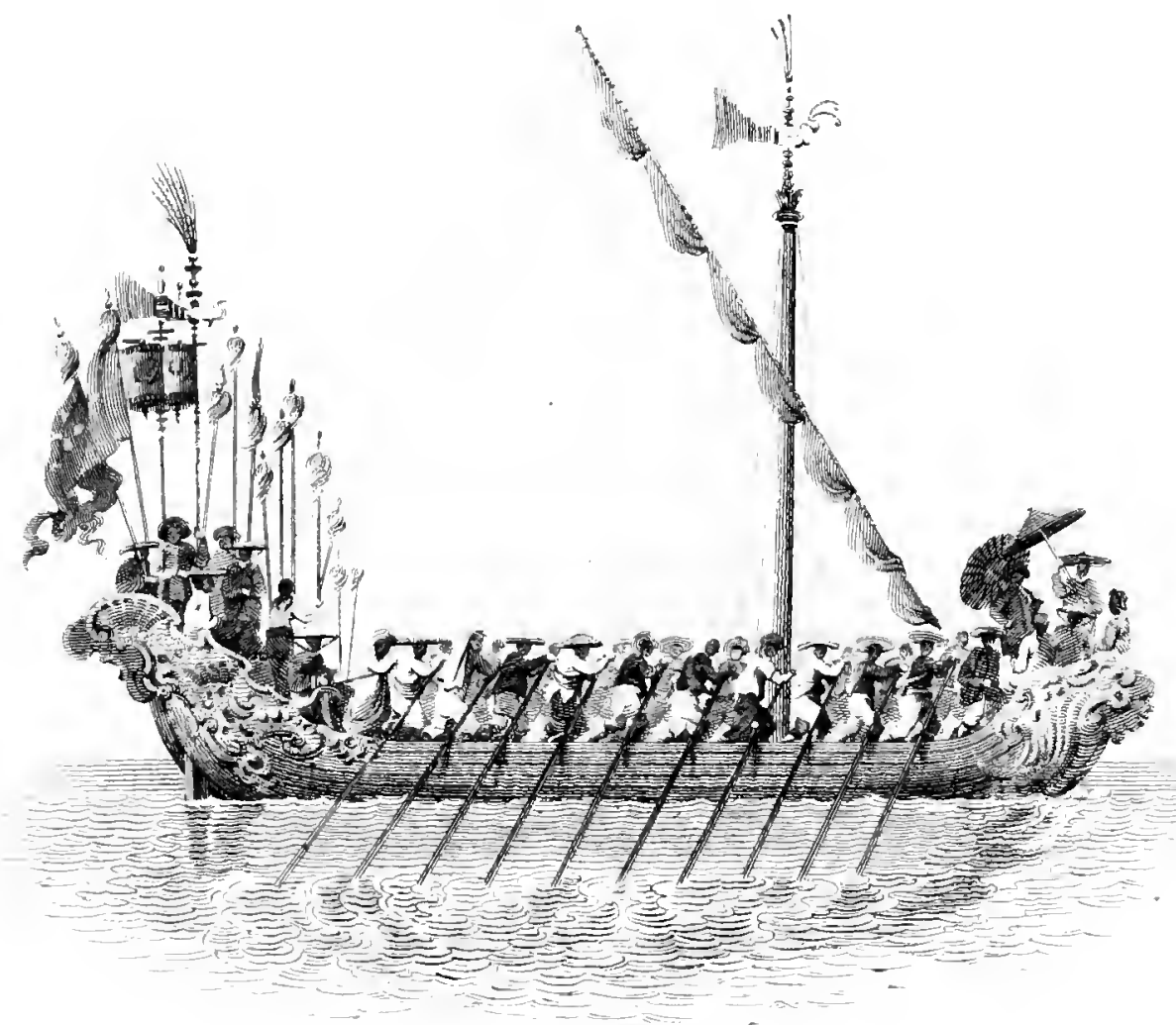


cochin. where the sciences are known; and, in some instances, they have fallen upon processes not rised enewhere, tho more convenient or effectual than thoso which are. In purifying sugar, after the gross syup lad bocu druined

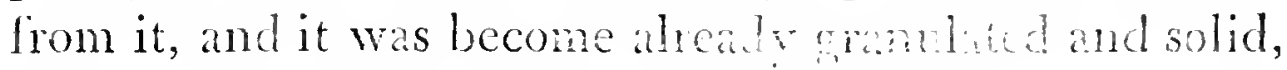
they sometimes placed it in layers of about one inch in thickness and ten in diameter, wher lagers of efual di-

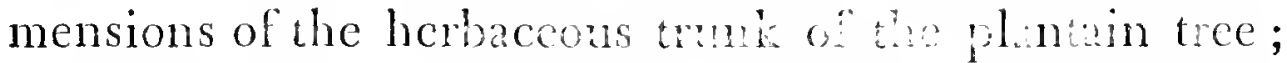
the watery juices exuding from which, and filuating through the sugar, carricd down with them all the dross which had been boiled up with is, kaving the pure sugar crystallized and white. It was then very light, and almost as porous as a honey-comb. When cissolved, it left no sediment at bottom. This method appears, ccrtainly, to be an improvement oil the usual mode, elsewhere, which consists in pouring the sugar, as soon as granulated, into vessels of the form of inveried cones, and placing a layer of wet earth upon the upper surface of the sugar. That upper surface is, thus, indeed, much purified; but never so perfectly as in the Cochin-chinese method. The grain of the sugar is more broken, and the inverted point of the loaf always retains more dross than does its base, to which the filmating liquid had been more immediately applied. It is not very probable, that the management of the sugrar cane and its juices, by the Cochin-chinese, is much more tedions, difficult, or expensive than what is pursued elsewhere; 
because the sugar made by them, and brought to the open market-places in the neighbourhood of the manufacture, was sold at prices considerably inferior to what are demanded in any other part of the world, where that commodity is produced.

Tho these people possessed not, scientifically, the art of reducing the metallic ore into the metal, they had attained the practice, for example, of making very good iron, as well as of manufacturing it afterwards, into match-locks, spears, and other weapons. Their earthen ware was very neat. Their dexterity appeared in every operation they undertook. It was applied, indeed, sometimes to improper purposes. Many of them made little ceremony of appropriating, privately, to themselves, whatever suited them in the possession of another; nor were they much disconcerted by detection.

They were liberal in their turn; and in instances, too, where few others are disposed to generosity. Wives and daughters were said to be transferred on easy terms, and with little scruple. All affairs of gallantry seemed, indeed, to be treated by them very lightly. These observations must, however, be considered as applicable, principally, to the more numerous, but lower classes of the people; and among them, to those who were so situated as to have most intercourse with strangers; while the upper orders were more comprehensive in their injustice, and more exclusive in their enjoyments ; exervoL. I. $\mathrm{x} x$ 
Cochin- cising their power over the weaker sex, in confining

china. their many wives, and over the people in a variety of oppressions, which neither the inferior was emboldened to resist, by depending upon his right; nor the superior deterred from continuing, by a consciousness of doing wrong; as if no principle of religion, or maxim of morality, had been inculcated among them in support of justice, or for putting any limit to authority. Subordination was strongly marked by prostrations and other exterior acts of abject humiliation to those in power.

Tho a great inequality of conditions tends, in some instances, to the cultivation of such of the fine arts, as happen to be esteemed, because it provides means for their encouragement, there did not appear among the Cochin-chinese the least traces of painting or of sculpture; but they had made some proficiency in music. The Embassador was induced to accept of an entertainment, given on shore on the fourth of June, being his Britannic Majesty's birthday. On this occasion a grand dinner was provided. After which a play was performed, in a style superior to any that had bcen hitherto exhibited. 'The piece appeared to be a kind of historical opera, in which were the recitative, the air, and the chorus, as regular as upon the Italian stage. Some of the female performers, were by no means despicable singers. They all observed time accurately, not only 
with their voices, but every joint of their hands and feet was obedient to the regular movement of the instru-

ments. Both their string and wind instruments were very rude, but formed on the same principles, and with a view to produce the same effect, as those of Europe. Such, however, is the force of habit and national attachment, that the performance of the nusicians, in the service of the Embassador, which was very grateful to the European ear, was not much relished by the Cochinchinese.

The building, in which the Embassador was received, appeared to have been erected on the occasion. The inside was hung with printed cotton of British manufacture; and the soldiers, attending upon the governor of the district, who gave the entertainment, had outside vests of dark red cloth, which likewise, probably, came from England. The Portugueze of Macao, who chiefly carry on whatever trade is still subsisting in the ports of Gochin-china, buy up the refuse goods of the Ganton market, which they dispose of here to great advantage, tho they sometimes are made to suffer many impositions from the governing people of the country.

The Cochin-chinese soldiery were generally armed, beside sabres, with pikes of vast length, ornamented with tassels of hair dyed red, which colour no subject, except in the service, or by the order, of the sovereign, was allowed to use in dress or equipage. The Embassador's 
Cochin- guard which attended his Excellency on shore, beside firing a salute in honour of the day, went through several military evolutions, to the admiration, not only of the surrounding multitude, but of the native troops.

Notwithstanding the decrease of population throughout the comntry, in the course of a long civil war, the number of men in arms was said to be still considerable. At Hué-foo, the capital of the kingdom, about forty miles to the northward of Turon, thirty thousand men were reported to be kept in garrison, and regularly exercised with muskets and match-locks every day. Their generals relied much also upon the use of elephants trained for war. With this view figures of soldiers are placed in ranks before the war-elephants, who are taught to attack them with great fury, seizing them with their trunks, tossing some of them in the air, and trampling others under their feet. The elephant, however, like most other animals who subsist entirely on vegetable food, is maturally gentle, except where pains are taken to train them to acts of violence, or when provoked by great personal injury. The keeper of this huge animal is generally a boy, who rides upon his neck and governs him with ease; and the nice touch and contractile power of the lips of his flexile proboscis, render it, in some instances, cqual to the human fingers in adroitness.

Cochin-china is among the few places where elephants serve for food. They were considered as a per- 
fect dainty there. When the king, or any of his viceroys in the provinces, has one of these animals slanghtered for his table, pieces of it are distributed about to persons of rank, as gratifying marks of favour. Buffalo is preferred to other beef. Milk is not used as food; nor is milking any animal customary in the country. Yet the people have been driven to dreadful shifts for any kind of sustenance, during the famine which the destroying armies of contending tyrants had frequently occasioned; and human flesh is said to have been, sometimes, sold in the open markets of the capital.

The neighbouring Tung-quinese had taken, at one time, the advantage of the rebellion in Cochin-chinit, and invaded the northern provinces, in which the capital is situated, and during the short period of their possession, they plundered whatever valuable they could find; and, in particular, as much of the precious metals as they could discover. A great proportion of what then escaped has been sent since to China, in return for the necessaries of life supplied by the junks from thence, the wretched inhabitants being often compelled to that resource, as their cultivated lands were laid waste, and their manufactories destroyed. Before these calamitous events, gold was particularly plentiful in the country. Gold dust was found in the rivers, and their mines abounded in the richest ore, so pure as to require only the simple action of fire to extract it. Much of it was used in deco- 
Cochin- rations of dress and furniture. The hilts and scabbards china. of their swords were frequently ornamented with plates of beaten gold. Payments were made in it to foreign merchants, in ingots, each weighing about four ounces.

Mines of silver were formerly less known, or so little worked, that it was imported from abroad and exchanged for gold, upon terms of considerable advantage to the importers. More mines of silver have, however, lately been discovered ; or a less expensive method of refining it has been practised. It was become the principal medium of exchange for merchandize from abroad, and was paid in ingots of very pure metal, each weighing about twelve ounces. Before the troubles in Cochinchina, great quantities of gold were brought from the hills in dust, and bartered by their rude inhabitants for rice, cotton, cloth, and iron. It was from them also that the sweet-scented aguila or eagle wood, so valued in the East, was brought, as well as quantities of pepper, wax, honey, and ivory; but the communication between those hills and the low lands had, in a great measure, been cut off for several years past. The latter chiefly produce rice, areca nut, betel leaf, tobacco, cinnamon, silk, cotton, and above all, sugar, which may be considered as the principal staple commodity of the country.

The original inhabitants of Cochin-china had retired to the chain of mountains bordering upon it to the westward, and those which separate it from Cambodia, when 
the ancestors of the present possessors of the plains invaded the country from China, in like manner as the ancient Britons, when attacked from Italy and Germany, betook themselves to the mountains of Wales. The mountaineers of Cochin-china are represented as a rude and savage people, differing by their coarse features and black complexions, as much as in their manners, from the well-looking and less dark complexioned lowlanders, who were considered as a courteous, affable, and inoffensive race, before the subversion of the ancient government, and mutual violence and treachery had loosened every principle of society, and roused the passions of avarice and ambition, which the convulsions of the country gave too many opportunities of indulging. The ancient simplicity of manners still, however, subsisted among the cultivators of the soil. The countenances of the peasants were, for the most part, lively and intclligent. The women, who were more numerous than the men, were actively employed in works of husbandry. Their cabins were clean and sufficiently commodious for a people whom the climate enables to spend, out of doors, most of the time not allotted to repose.

Of rice, which is the most general object of cultivation, beside that species which requires to be sown in lands that are afterwards inundated, there is another known in Cochin-china, called sometimes mountain rice, which thrives in dry light soils mostly on the sides of hills, and 
Cochin- opened by the spade, nor does it require more moisture clina. than the usual rains and dews supply, neither of which is frequent at the season of its vegetation. Rice is of still more importance to this people, here, than bread is to Europeans, as the former require, with that grain, a very trifling relish of spices, oil, or animal food. Their principal indulgence is in spirituous liquors, tobacco, areca nut, and betel leaf; of the two last articles, mixed with a little paste of lime and water, they are extravagantly fond. These ingredients are obtained at easy rates, being produced upon the spot. Persons of both sexes, and of all ranks, chew the areca nut with betel, and smoke tobacco. A silken bag, suspended from the girdle, containing those ingredients in separate divisions, constitutes a necessary part of dress. Every man, who can afford it, is attended by a servant, whose office is to follow his master with his apparatus for smoking. The gentleman carries only a small case, or purse, for his areca nut and betel, generally slung over his shoulder, with an ornamented riband hanging down to his waist. Portraits of these are delineated in Plate No. 16.

The custom of smoking, to which the men are more addicted than the women, aflords a sort of occupation that prevents the irksomeness of total inaction, without requiring excrtion or occasioning littigue. It is, therefore, often preferred to more useful, but laborious em- 
ployment; and, cxcept occasional efforts, made under particular circumstances, indolence was prevalent among the men; while the women were assiduously employed in domestic occupations, or in the labours of agriculture. In towns they served frequently as agents or brokers to merchants from foreign countries, living with them at the same time as their concubines; and, in both respects, they were remarkable for their fidelity. Concubinage was supposed to be no dishonour; and, in this instance, there seemed to be less difference in the morals of the two sexes than in Europe. The exterior difference between the sexcs appeared also less glaring; for the dresses of both were nearly of the same form. They consisted of loose robes, with small collars round the neck, and folding over the breast, with large long sleeves, covering the hands. People of rank, especially the ladies, wore several of these gowns, one over the other. The undermost reached the ground; the succeeding ones were each shorter than that immediately under it. They were often of different colours, the display of which made a gaudy appearance as the wearer walked along. Linen was not known amongst them. They had, next the skin, vests and trowsers of slight silk or cotton. Turbans were frequently worn by the men; and hats, sometimes, by the women, but never caps. The most richly dressed of either sex used no shoes.

In the dress of the Europeans nothing attracted VOL.I. $\mathrm{Y}_{\mathrm{y}}$ 
Cochin- more the attention or admiration of the Cochin-chinese china. than manufactured ornaments of polished steel. Steel hilted swords were vastly coveted by the military men. This class held the first rank in the country. Next came the judges; but the abuse of power in the former was not greater than in the latter; and among the several hardships, suffered by all classes, were the bad practices in the establishments intended for the administration of justice. Causes were tried, indeed, with much formality, and an apparent desire to find out the truth, in order to a fir decision; yet, in fact, a fivourable decree was generally purchased by a bribe. Presents were accepted from both parties; but the richest was most likely to be successful.

Among objects of natural curiosity accident led to the observation of some swarms of uncommon insects busily employed upon small branches of a shrub, then neither in fruit or flower, but in its general habit bearing somewhat the appearance of a privet. These insects, each not much exceeding the size of the domestic fly, were of a curious structure, having pectinated appendages rising in a curve, bending towards the head, not unlike the form of the tail feathers of the common fowl, but in the opposite direction. Every part of the insect was, in colour, of a perfect white, or at least completely covered with a white powder. The particular stem, frequented by those insects, was entirely whitened by a substance or powder of that colour, 
strewed upon it by them. The annexed engraving will cochinconvey some icten of what is lhere very inperfectly de-china. convey some idea of what is here very imperfectly described. The substance or powder was supposed to form the white wax of the East. This substance is asserted, on the spot, to have the property, by a paticular manipulation, of giving, in certain proportions, with vegetable oil, such solidity to the composition as to render the

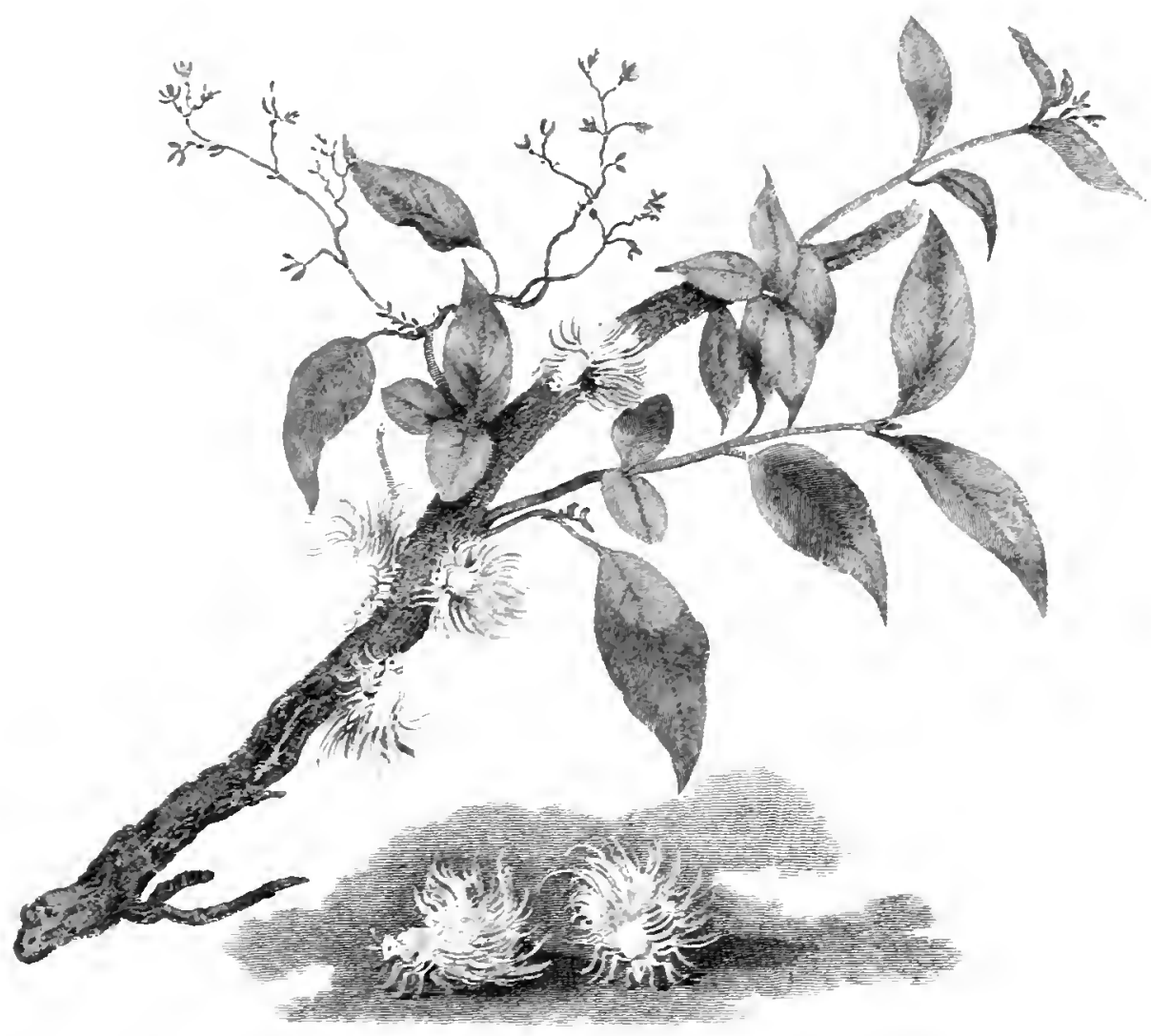


Cochin-
chind. whole equally capable of being molded into candles. The chint. fact is ascertained, indeed, in some degree, by the simple experiment of dissolving one part of this wax in threeparts of olive oil made hot. The whole, when cold, will coagulate into a mass, approaching to the firmness of bees' wax.

Considering Cochin-china in a general view, it must be allowed to be excellently well adapted to commerce. Its vicinity to China, Tung-quin, Japan, Cambodia, Siam, the Philippines, Borneo, Sumatra, and Malacca, renders the intercourse with all these countries short and easy. The commodious harbours with which the coast is intersected, and particularly that of Turon, afford a safe retreat for ships of any burden, during the most tempestuous seasons of the year.

As a good plan of so valuable a harbour as Turon might be of use to future navigators, and would be a desirable addition to nautical knowledge, Mr. Barrow undertook to draw it agreeably to geometrical admeasurement; and, for that purpose, " selected a level sandy "beach on the south-west side of the harbour, as the " most advantageous place on which a measured base " could be had, and from the extremities of" which the " greatest number of points might be secn. He carefully " measured, with a chain, a base of one nautical mile, " and with a small thcodolite took a set of angles from " each extremity, by which the general outline of the 
"harbour was completed as far as the projecting point of "the peninsula, called, in the chart No. 3, the second

" point. The rest of the coast, forming the entrance " of the harbour, was laid down by intersections on "board the Jackall, as she was working out of the " harbour, on her passage to the island of Callao. He " estimated the width of the isthmus, that is connect" ed with the peninsula, by walking across it from "the harbour to the open sea. The soundings in the " entrance of the harbour were obtained in the Jackall, "and those in the channel between the banks, and in "the mouth of the river, were taken at low water by the " two brigs, in their passage towards the town of Han"sán. The situation and direction of the banks were " determined by taking their bearings from various parts "of the bay, and intersecting those afterwards from the "Hindostan. The latitude of this ship's anchorage, by "the mean of several meridional altitudes of the sun, "was found to be sixteen degrees seven minutes north, " and longitude, by the time keeper, one hundred and " eight degrees twelve minutes east from Greenwich. "The rise and lall of the tides appeared to be very un" equal. The greatest rise observed, during the squa" dron's stay, was about six feet; but it was said to rise, "sometimes, as high as eleven or twelve feet. The time "of high water, at full and change, was about five or "six o"clock in the afternoon. 
Cochin- "The following are references to the chart of the har"bour of Turon.

"A. An irregular mountainous peninsula, inacces"sible on every part of the coast, except that adjacent " to the harbour, and at the two small sandy bays in the " entrance (marked $\mathrm{N}$ and $\mathrm{O}$ ), at the bottom of each of "which are a few fishermen's huts. To this peninsula " was given the name of New Gibraltar, on account of " the similar local natural advantages which it possesses, " and which render it capable of being made, like the " other, almost impregnable. This peninsula is called " by the natives Tien-tcha.

"B. A level isthmus, united to the above peninsula, " from three-fourths of a mile to a mile in width, con" taining several small villages and patches of ground, " under cultivation, chiefly of rice, tobacco, pulse, and “ sugar-canes. The small elevation of this isthmus above " the level of the sea, and the loose sandy materials of " which it is composed, would at any time render a deep " cut across it practicable and easy, should the insulation " of the present peninsula ever be thought advisable. "G. The principal town in the vicinity of the har" bour, at which the market is held. The land around " this town appears to be kejt in a state of tolerably good " cultivation. The name given to it by the natives, as " well as to the harbour, is Han-sán.

"D. A small island covered with trees and thick 
"brushwood. The depth of water being three fathoms " within a ship's length of the southern extremity of

"the island, a convenient place might be prepared, at " a small expence, for heaving down and repairing "ships. The northern point of this island is connect" ed with the peninsula by a reef of rocks, that are un" covered at low water. By making these rocks the "foundation of a pier or causeway, an excellent dock " might be constructed between the island and the pen" insula. A place like this would be well calculated for " repositories of naval stores, magazines, or warehouses. "E.E. Rills of clear water, from which shipping " might be supplied with great convenience.

"F. A small plain, on which tents were erected for "the reception of the sick. A town built upon this " plain would command a direct and very commodious "communication with the shipping in the harbour. "By a small work on the first point, which is consider" ably elevated, the town might be defended against any " force, that would probably ever be directed against it. "G. A valley, in which there is a small village, a " rivulet of clear water, and about forty or fifty acres of " land under tillage; a great part of which was in a " state of preparation to be planted with rice. " H. K. Villages, at which several manufactures are " carried on, particularly those of boat-building, and of "preparing sugar and tobacco. 
Cochin- "L. A large village on the banks of a considerable
china. china. "river, across the mouth of which there is a shallow " bar, but within it three fathoms water. The valley, " through which this river meanders, is beautiful and " extensive, and seems to be fertile and populous. "M. A cove with plenty of water for ships of any "burden, good anchoring ground and well sheltered, "particularly from the north-east monsoon. At the " head of this cove, there is a plain of considerable ex"tent, containing two villages that are divided by a " small rumning stream. About forty or fifty acres are " employed in the culture of rice. A number of fine " buffaloes were grazing on the marsh.

"P. A group of curious marble rocks, that extend "across the isthmus, one end being washed by the sea, " and the other overhanging the river. These rocks "rising immediately from a perfect plain, like an im" mense pile of building in ruius, appear, on making "the peninsula from the southward, to be situated in the "sea."

In the neighbourhood of Turon, and along the adjoining coast, the winds have been found variable all the year, as, indeed, they are close in with most lands, the periodical winds losing their influence near the shore. The captain of the Pocock Indiaman, whom necessity had compelled to go into Turon in the month of November, during the north-east monsoon, was very 
apprehensive of engaging with that coast, which he cochin. considered as a lee-shore at that season of the year; but experience shewed him that there was little to be feared. The comtry is supposed, in gencral, to be healthy, the violent heat of the summer months being tempered by regular breezes from the sea. September, October, and November are the season of rains. The low lands were then frequently and suddenly overflowed by immense torrents of water, which descended from the mountains. The inundations took place, generally, once a fortnight, and lasted for two or three days at a time. These inmmdations happening about the full and change of the moon, seemed to indicate the influence of that satellite in the determination of their periods. In December, January, and February, there were also frequent rains, brought by cold northerly winds, which distinguished this country, by having a winter, from most others so near to the equator.

The inundations had the same effect here, as the periodical overflowings of the Nile, and rendered this country one of the most fruitful of the globe. In many parts the land produced three crops of grain in the year. Its most valuable produce, beside the precious metals, consisted in pepper, cinnamon, sugar, silk, and cotton, which were readily given, by the natives, in exchange, for a variety of European manufactures; and, accordingly, several of the principal commercial nations of 
Cochin- Europe, trading to the East, had considerable intercourse china. with the Cochin-chinese, and their neighbours the Tung-quinese. But nothing is now to be seen in any of their harbours except their own galleys, a few Chinese junks, and now and then a small Portugueze vessel from Macao. The ravages of civil war have, no doubt, contributed to drain the sources of commerce; and the want of security and protection to foreigners, inclined to trade there, must impede its revival.

Not only large sums have been demanded for permission to trade, as well as arbitrary duties levied on goods carried there for sale, and a variety of presents exacted by all persons in power or office, with whom the foreign merchants had to deal; but sometimes the vessel and whole cargo have been attempted to be cut off. Of this a strong instance is recorded, among the manuscripts of the East India Company, to have happened in the year 1778 .

"Two English vessels were sent from Bengal, with a " view to open a trade in the peninsula of Cochin-china, "upon certain fixed conditions. For this purpose a " gentleman was deputed by the government of Bengal, " with powers to treat with the rulers of the country. "He was well received where he first stopped in the "southern provinces, from whence he was invited to "Hue-foo, the capital, then in the hands of the Tung"quinese, where assurances were given that the cargoes 
"on board might be clisposed of to advantage. One cochin" only of the vessels could aet over the bar, which lies china.

" at the mouth of the river leading to it, while the "largest remained in Turon harbour. Some of the "goods were landed at Huć-foo, where the agent for " their sale, as well as the Bengal envoy, resided for " some time. Presents were made, as usual, to the prin" cipal officers of government, and part of the cargo " was sold, when the envoy discovered that the viceroy, " allured by the hope of obtaining a valuable booty, had " issued orders for seizing the persons of all the Eng"lish ashore, and for confiscating the vessel and cargo. "The English at Hué-foo just had time to get on board, "when troops surrounded the dwelling they had left. "Their safety required, that they should sail away as "fast as possible; but it was extremely dangerous to "attempt crossing the bar, at the inclement season " which was then, in November, set in. The vessel " had been nearly lost in crossing it, on her arrival, in "the finest weather, tho she had then been assisted by " the boats, and people of the country. The north-east "monsoon, now at its heiglit, blew directly up the "river. A message was sent to the vessel, lying in "Turon bay, to come to the mouth of the river, or to "send boats and people to assist her consort, in attempt" ing to get over the bar, in any moment, when the " weather should prove moderate, or the wind shift to voL. I. $\mathrm{Z} z$ 
cochin- "a less unfavourable point. In the mean time they had

china. "accounts, that the chests and packages, they had been " obliged to leave behind them at Hué-foo, were broken "open by Tung-quinese soldiers, and the contents " carried off. Soon afterwards they perceived armed " gallies full of men, dropping down with the tide, and " making no other use of their oars, than to preserve a " proper direction for boarding the English vessel. " Had they been suffered to come along side, she must " have inevitably been taken. The gallies were, there" Core, hailed, and desired to keep clear of the ship; "they continued, however, to approach, without re"turning any answer; and were stopped only in con"sequence of guns being fired at them from the vessel. "Batteries now began to be erected, by the people " ashore, in order to prevent her escape.

"In the mean time an European linguist came with "a message from the viceroy, to assure the English of " the continuance of his friendship; that the ill treat"ment they had suffered was without his consent, or " participation, and that he earnestly desired an accom"modation. After delivering this message, the linguist " taking the Luglish envoy aside, said to him, that tho " such was the fair speech that had been ordered to be "made to him; yet it was incumbent upon the English "to be constantly on their gurnd, as the Tung-quinese " were manning norc gallies, in order to take the vessel. 
"A civil answer was returned to the viceroy, and a de" mand made of the property, that hat been seized at

"Hue-foo. Promises were soon sent that it should be " restored, and an intervierv requested. The person, " however, by whom these promises were conveyed, " privately mentioned the insincerity of such profes" sions, and that, in fact, hostile preparations were car" rying on against the vessel.

"On the twenty-fourth of November, the weather "appearing moderate, the captain of the ship moved " her nearer to the river's mouth, about a mile above " the spot where a prodigious high surge broke across " the bar. On each bank of the river, thereabouts, were " crowds of people busied in bringing down guns, fas"cines, and stores, and in erecting batteries, which, " notwithstanding every effort to interrupt them, were "soon completed, and began to play upon the vessel, " tho with little effect. They were inexperienced in the " management of guns, and took, as yet, bad aim. They "ceased fring during the obscurity of the night; but " in the course of it the vessel was exposed to another " danger; a heavy swell drove her from her anchors, "and several violent shocks announced that she was "striking upon the ground; and it was to be dreaded "that she soon would come to pieces. Fortunately, " however, it happened to be low water; when the " tide rose, she got off without damage. But the boat on 
cochin. ." which the people's ultimate hopes were placed for china. "preserving their lives, in case of an accident to the ". vessel, broke loose and was seen no more.

"In the moming an English boat was perceived by "them, outside the bar, attempting to get in, and was "known to be that which was expected to come to their "assistance from Turon. Their spirits were elated by " this incident; but their joy was of short duration ; "for the boat, after rowing to and fro, at the back of " the surge, in search of the proper channel, unfortu" nately, made choice of a part where it broke with the " greatest violence; and no sooner had she entered it, " than she disappeared. The deepest consternation, " immediately, became visible in the countenances of " all aboard. The Tung-quinese, to express their joy " at the accident, fired with redoubled fury from their " batteries at the ship. Regardless of the danger, every " eye on board, appeared fixed with a melancholy " steadfastness on the place where the boat had overset. "In about an hour the heads of two persons were dis" covered, swimming towards the vessel, and they soon " reached her. The rest of the boat's crew were drown" ed or killed by the Tung-quinese, who had the " cruelty to fire at them, when in the water, with small " arms.

"In a short time the vessel suffered considerably "from the batteries on shore. The night brought some 
"respite from this danger, but, hy dfording time to the

"people to reflect on their situntion, served rather to

" increase than to alleviate their anxicty. The vessel

" had already received considerable damage in her hull "and rigging. She was riding by the only anchor "which remained, that could be depended on ; and " expedients for deliverance were sought in vain. There

"was little hope of safety in proposing an accommoda"tion; and yet nothing else remained to be done. A " white flag was accordingly hoisted; and signs made " to some of the Tung-quinese to come on board. They, " on their part, immediately began to pull down the war " Hag displayed on their batteries: they were perceived " to assemble in consultation at the grand battery; and " a boat attempted to come on board, but was obliged "to put back by the high sea. The Tung-quinese, " waiting probably for orders from the viceroy, suffered "the vessel to remain unmolested the whole day. In "the evening the wind so far changed as to render it " possible to get out. The anchor was accordingly "weighed as soon as it was dark, and the sails set in " profound silence. There was, indeed, but a slender "chance of finding the way, in the obscurity of the " night over a dangerous bar, through a channel not " more than sixty yards wide. At one moment the ves" sel's head was close upon the breakers of the sea, when " Juckily her sails were taken aback, and she avoided 
cochin- " them. A little before midnight she crossed the

"bar. The Tung-quinese, then perceiving that the "ressel was giving them the slip, kept up a brisk "fire till long after she had got out of the reach of their "guns."

Similar instances have, probably, occurred to other nations, which determined them to abandon the trade of Tung-quin and Cochin-china altogether. The French, it is said, aware of the insecurity of trading to those countries without some independent settlement, had, formerly, in contemplation to purchase the small island of Callao, lying a few miles to the southward of Turon. Such a circumstance rendered that island, in some measure, interesting; and Captain Parish and Mr. Barrow went in the Jackall tender to visit it, but under injunction to avoid giving any kind of offence or alarm to its inhabitants.

"On approaching the north-east coast of Callao," according to Mr. Barrow's account, " and standing well " in towards it, they stretched along the eastem shore "of the island, towards the southward, near enough to "perceive that, on that side, from the northern to the "souhlien extremity, there was no landing place what" ever, the shore consisting of a continued range of im"mense rocks, rising, in some places, perpendicularly " out of the sea, and, in others, overhanging it in such "a manner as to render it completely inaccessible. 
"About half a mile from the southernmost point of

"Callao was a small rocky islet, round which they

"sailed, not caring to venture the brig through the

"passage formed by it and Calliao; tho, from the ap-

"pearance of the two shores, and the depth of water

"abreast of the opening, it scarcely conld be doubted

" but that the largest ships might have passed through

"without any risk.

"Having hauled round the rocky islet, they began

" to open out the south-west coast of Callao, which

"soon discovered itself to be of a very different na-

"ture from that of the opposite side, being covered

"with verdure, and indented with a number of small

" sandy bays, in all of which there was the appear-

" ance of safe and convenient landing. They stood

" in towards the largest of those bays. Near the shore

"were distinguishable a number of houses, and, not far

"from them, several boats, some afloat, others hauled

"upon the beach; and beyond the village, lands in cul"tivation. The water shoaling, very suddenly, from

" nine to five fathoms, it was thought advisable to let go

"the anchor. The two projecting points, forming the

"bay, bore north seven degrees west, and north thirty" six degrees east; the latter about a mile and a half " distant. It was afterwards found that the vessel had "been brought to just upon the point of a bank, that "stretched out about a mile from the extreme points 
Cochin- "of a small island to the westward of Callao, and bearchina. "ing from the anchorage north twenty-six degrees west, " and north sixty-six degrees west.

"The brig had been scarcely brought to anchor, and "the sails clewed up, before they observed eight very " large two-masted gallies, and a few smaller ones stand" ing out of the bay, apparently with an intention of " coming towards the Jackall; but they had no sooner "cleared the points that form the bay, than they hauled " their wind, and stood along shore towirds the northern " extremity of the island, and having reached a passage "between it and a small islet lying to the westward of " it, they furled their sails, and, with their oars, brought " all the gallies into a regular line ahead, occupying " the whole passage. The brig hoisted English colours, " on the idea that some of the people might recognize " them, as similar to those flying in the harbour of "Turon.

"The gallies, however, still kept their position; "while the Jackall's boat landed at the bottom of the "bay, on a fine sandy beach, upon the margin of which "stood a small, but very pleasant village, built chiefly " of bamboo. None of the natives had appeared upon "the beach, nor were seen about the houses; and on "entering into them, it was discovered that the village " was deserted. The doors of the houses vere all left "open; and several domestic animals were feeding before 
"them. Alter some time a person was perceived lurk" ing among the neighbouring trees, who, finding he

" was observed, came forward with reluctance, and evi" dent marks of fear. While he was yet at some dis" tance, he fell upon his knees, and touched the ground " with his forehead several times. On approaching to " him it was noticed that the first joint of every one of " his fingers and toes were wanting, and as if twisted "off by violence; it was possible that he might have "thus been treated by way of punishment for some " crime; and that he was considered as the fittest person " to be exposed to the supposed danger of watching the " movements of the strangers coming ashore. In a little " time some others, hidden in the thickets, finding that " no mischief was suffered by the first, ventured out. " None of them could understand the Chinese interpre"ter, and not being able to read or write, there was no " conversing with them by the medium of the Chinese " characters. Recourse was had to hieroglyphics; and " rude figures were drawn of the articles which were " proposed to be purchased; and this method succeeded " tolerably well; poultry and fruits were brought for "sale, for which high prices were given, purposely " to conciliate the good will of those islanders. There "were very few of them present on it, the principal " inhabitants having embarked, it seemed, in their gal"lies on the brig's approach to the island. They who vOL. I. 
Cochin- "remained grew soon familiar; and one old man presschina. "ingly invited the strangers to his house, situated upon " an eminence, at a little distance. On arriving there, " he introduced them to his wife, an old woman, who, after " recovering from her astonishment at the sight of figures " so different from those she had ever been accustomed " to behold, laid, in a neat manner, before them some "fruits, sugar, cakes, and water. On departing from "the house, this decent and hospitable couple made " signs to testify their desire of seeing them again. "To avoid exciting suspicion or alarm among the " people, which any considerable apparatus of instru" ments, or operations on shore might have created, "Captain Parish and Mr. Barrow took with them, only, " a small pocket sextant and compass. With these, at " the southernmost point of the bay, they observed the " necessary angles and bearings without being noticed; " and rowed on board, taking notes of the soundings all " the way. A second set of angles was observed on " board the Jackall at anchor, from which and the for" mer, the chart of Callao and the adjacent islets was " constructed. And in order to ascertain the distance of " the brig from the shore, as accurately as circumstances " would allow, the angle of the altitude of her mast " above the surface of the water was taken from the "shore, from whence her distance was deduced trigo" nometrically. By estimating the motion of the boat 
" on its return to the vessel, and noting the time em"ployed in it, the distance resulting from thence was

"found to correspond, very nearly, with that which " was obtained by calculation from the angular altitude " of the vessel's mast. The height of the southern peak " of Callao was found by observing the angles of its " altitude with a sextant, at eight different stations, as"sumed at as many equal intervals of time, on their way " to the vessel. They also had an opportunity of deter" mining the latitude of the island, by a meridional al" titude of the sun; from which, and the bearing of the " peak from Turon harbour, taken with an azimuth " compass, the relative positions of those two places " were marked down in the chart.

"Callao, as it is called by its inhabitants, but more "generally known to Europeans under the name of Cam" pello, lies opposite to, and abont eight miles to the east" ward of, the mouth of a considerable river on the coast " of Cochin-china, on the banks of which is situated the "town of Fai-foo, a place of some note, not far from the " harbour of Turon. The bearing of the highest peak of "Callao from this harbour is about south-east, distance "thirty miles. The extreme points of the island lic in " latitude fifteen degrees fifty-three minutes, and fifteen " degrees fifty-seven minutes north; the greatest length " is from north-west to south-east, and is somewhat about " five miles, and the mean breadth two miles. The only 
Cochin- " inhabited part is on the south-rvest coast, on a slip of china. "ground rising gently to the east, and contained between " the bottom of a semilunar bay, and the mountains on " each side of it. Those mountains, at a distance, appear " as if they formed two distinct islands. The southern "mountain is the highest, and is about fifteen hundred "leet. The lower grounds contain about two hundred " acres. This small, but enchanting spot is beautifully " diversified with neat houses, temples, clumps of trees, "small hillocks swelling from the plain, and richly de" corated with shrubbery, and trees of various kinds; "among which the elegant areca, rising like a Corin"thian column, is eminently conspicuous. A rill of "clear water, oozing from the mountains, is contrived " to be carried along the upper ridges of the vale, from "whence it is occasionally conveyed through sluices, "for the purpose of watering the rice grounds, and ap" peared, tho then in the dry season, fully sufficient for " every purpose for which it could be wanted. "The houses, in general, were clean and decent; a " lew were built with stone, and covered with tiles. $\therefore$ One, probably the mansion of the chief person of the $\therefore$ island, was inclosed by a stone wall, and the approach " to it was though a gateway between two stone pillars. "The house was divided into a number ol apartments, "of which the arrangement did not seem to want either "taste or convenicnce. This building stood at the head 
"of the principal village, which consisted of about

" thirty habitations built of wood, chiefly the bamboo.

"Behind the village, and on the side of the hill, was a

" cave, accessible only by one way, through an irregular

" range of rocks. Within the cave, but near its mouth,

" was a snall temple, commanding a view of the whole

"vale. Several other temples were dispersed over the "plain, all of which were open in front, with a colo-

" nade before them of round wooden pillars, painted red

" and varnished. The number of houses on the island

" scarcely exceeded sixty. Behind every house, not im" mediately in the principal village, were inclosures of " sugar canes, tobacco, and other vegetables, growing in " great luxuriance. The mountains were covered with "verdure, and seemed well calculated for rearing goats, " of which the island produced a few.

"Beside the principal bay, there were several sandy " inlets, with small patches of level ground behind " them. Boats might easily land in any of these inlets, " but a communication between them, by land, appeared " to be exceedingly difficult, if not entirely prevented, " by the steep and rugged ridges which separated them "from each other. On this account very slight works, " and an establishment of a few men, only, would be " requisite for the defence of the island, a great part of " its coast having been, as was already noticed, impreg" nably fortified by nature. The depth of water in the bay 
Cochin- " and road was sufficient for ships of any burden, and china. "there was perfect shelter from every wind except the " south-west, to which quarter it was directly open. "The short distance, however, from the continent in " that direction would always prevent the sea from rising " high, tho it might not be sufficiently near to break the "force of the wind."

The want of shelter in the south-west monsoon would soon induce the French, were they once in possession of Callao, to seek for a further settlement near it, upon the main land of Cochin-china. The coast abounds with navigable rivers. In settled times several hundred junks, from forty to one hundred and fifty tons burden, from the different ports of Ghina, frequented those of Cochinchina, to procure cargoes, chiefly, of areca-nut and sugar, the last article alone equalling annually about forty thousand tons. They paid for these cargoes in a few manufactures of China; but, for the greatest part, in silver. The distance is very short between the two countries, and the voyage made in four or five days with a favourable monsoon; and, as these junks leave their own ports almost in ballast, it is probable that they would, readily, bring teas, or other articles in demand among Europeans, for a trifling freight to Cochin-china. It being generally understood that no duties are levied in China on articles of trade exported by its own subjects on their own vessels, possibly the French might have had in con- 
templation to be able, by the means of a settlement on the coast of Cochin-china, to procure Chinese articles at a cheaper rate than could be obtained by any foreigners trading immediately to China, where the duties and exactions, amounting, upon an average, to about ten thousand pounds upon every considerable ship and cargo, must materially affect the price of the exported articles, and enable those exempted from them to be sold at a lower rate in Europe. While, indeed, the jealousy of foreigners continues so great in China as to confine their trade to Canton, the method of carrying it on by their own vessels, sailing between their own ports and Cochin-china, might be desirable, especially if the European manufactures could by those means, as is likely, be imported, not into Canton only, but into other Chinese ports. Until such jealousy shall be done away by a more familiar communication with the government of Ghina, which must be followed by the vent of an immense quantity of foreign manufactures throughout the whole empire, the mode of obtaining their commodities, and supplying them with those of Europe, through their own people, might certainly be more advantageous and secure, as well as more agreeable to them, than by the present method of foreigners going immediately amongst them.

If, from these considerations, a solid settlement in Cochin-china were to be productive of advantage to any 
Cochin- European nation, it must peculiarly be so to Great Brichina. tain; because, beside the opening it would make for the sale of its own manufactures, among the people of the country, the British possessions in Hindostan would be sure of a very considerable demand from thence for their productions.

After about a fortnight's stay in Turon harbour, preparations were made by the squadron for their departure. The monsoon was now become steady and favourable for a quick passage to the coast of China. The invalids from the Lion, who had been ashore, were returned aboard in better health, and the ship was freed from all traces of any contagious distemper. One loss, however, was sustained about this time, which was sincerely regretted by the passengers and crew. Mr. Tothill, purser of the Lion, was obliged, while she lay at Batavia, to go frequently ashore, for the purpose of procuring provisions and other necessaries for the ship's use. On these occasions he underwent much fatigue, and was often exposed to the sun's raging heat. He had afterwards some gouty complaints, and considered his late indisposition as a continuance of them. The symptoms did not appear alarming; nor was he confined to his bed; and he thought himself, latterly, as in a mercantile phrase he expressed it, a thousand per cent. better than he had been: the same night he died. Mr. Tothill had formerly been round the world with Sir Erasmus Gower, and chose to 
accompany his friend upon the present occasion; tho he had quitted a sea-faring life several years before.

About this period a circumstance, of another kind, created some temporary uneasiness. Mr.Jackson, master of the Lion, who was, during the whole voyage, assiduous in observing the soundings, and making other nautical remarks, especially in places little navigated before by Europeans, had gone upon a similar pursuit in one of the ship's boats, along the eastern shore of the peninsula of Turon. He did not return at night as was expected; nor were any tidings had of him the next day; his friends were naturally alarmed about him. He might have perished in consequence of a sudden squall having overset the boat. The various accounts of the treacheries and cruelties, which had been committed against strangers on this coast, recurred to the mind upon this occasion; and it was possible also that a discussion might take place upon the subject with the acting government of the country, which might be tedious and unpleasant. A rumour soon reached the ship that Mr.Jackson, his boat, and crew, had been seized, and detained at a distance from Turon; and soon afterwards it was acknowledged by a Cochin-chinese mandarine, who came on board, that some foreigners were detected and stopped in the attempt of penetrating, in the night time, up one of the rivers, in an unwarrantable, or, at least, in a suspicious manner. On their being claimed by the EmVOL. I. $3 \mathrm{~B}$ 
Cochin- bassador, a promise was made that they, together with

china. their boat and effects, should be restored. They returned in a few days on board; after having undergone considerable fatigue, and much ill treatment from the inferior officers, into whose hands they fell. In other respects, the accident was attended with the advantage of furnishing an opportunity of knowing the actual state of that part of the country through which Mr.Jackson was conducted.

He mentioned that, "desirous to survey the eastern " coast of the peninsula of Turon, he proceeded along " shore till he got to the isthmus point, when the sea " breeze set in. He then made for the entrance of Fai" foo river, opposite Callao island, and knowing that it " was a branch of a larger river, of which another branch, " at a little distance, fell into the harbour of Turon, he " determined to return by that way to the ship; that " after going through several windings of the river, for " upwards of twenty miles, he arrived, about eight "o'clock at night, before a large town, built along the " bank of the river, where he stopped about a couple of " hours, at the end of which time two men, each having " a lighted bamboo in his hand, made signs to him to go " ashore. They called out, also, to two armed gallies, " which were near the boat, to take hold of it. Upon " this he went on shore, and was received by a guard "of fourteen men, who conducted him to a house in the 
"town, where he staid during the remainder of the

" night. After some noisy debate the next moming,

" among the persons who seemed to direct the others,

" one of them went off in a great hurry; while Mr. Jack-

" son and the boat's crew were moved to a fort a little

"way beyond the town, where they were confined,

" handcuffed, and treated with great inhumanity, till the

" arrival of a person of authority above the rest, who

" appeared very much displeased at such behaviour.

"These prisoners were afterwards marched for two

" days, several miles through the country, exposed to the

" scoffs and menaces of their conductors and the people;

" until at length they reached their boat, and embarked

"for Turon harbour.

"The country, Mr. Jackson added, to the south-west

" of Turon, and as far as he could observe, in that di-

"rection, was level and fertile. The soil was chiefly

" clay, mixed with sand of a reddish colour. He met

" with many rivers and canals, full of boats of various

"sizes. There were junks of about one hundred and

" thirty tons. They lay before a town of about three-

" fourths of a mile in length, built of red bricks. All the

" large buildings were much damaged in many places, as

" if by violence. The town was about twelve miles from

"the sea, and twenty-four from that of Turon or Ham-

" san. He passed through two other considerable towns.

"In one of them was a plentiful market, from daylight 
Cochin- " until noon, abounding chiefly in rice of different china. "qualities, yams, sweet potatoes, greens of various " kinds, pumpkins, melons, sugar in round white cakes, "sugar-canes, poultry, and hogs. In the market were " stalls made of bamboo, with shops for the sale of cloths " and other goods. The country appeared very popu"lous, and the people, both male and female, very in"dustrious.

"Their fields were separated, not by fences, but by

" narrow paths running between them. To the grounds,

"which could not be watered by the rivers, water was " conveyed in jars, carried by the cullivators of the "soil. The land was ploughed by two buffaloes yoked " together; the plough seemed to be made of wood " alone. The fields planted with sugar-cane, were more " extensive than any others. The sugar sold in the " markets for about three-halfpence a pound. Every "other article equally cheap; cotton was very plenti"ful. The children were employed in picking it ont "of the pod, and the women in spinning and weaving " it into a coarse cloth, mostly dyed with indigo. The " horses ivere small, but spirited and active. They had "also asses and mules, and innumerable goats. The "people appeared to be very much oppressed by per"sons in office, and by the soldiers, whose behaviour "was that of brutal savages. Their arms were chiefly : long pikes, spears, and cutlasses, exactly resembling 
" those in English ships of war. He saw no cannon; " but many wall-pieces with wide bell numzles. The

"roads were little wider than pathways are in Europe. "Nor did he see any carriages or machines, which " would require broad roads to move upon."

The whole of the Cochin-chinese dominions, since Tung-quin has yielded to the arms of the late usurper, fills the space between the twelfth degree of northern latitude, and the tropic of Cancer; but their breadth do not amount to two degrees of longitnde. They are bouncled to the westward by a long chain of mountains, which border, on the other side, on the kingdoms of Laos, Siam, and Cambodia. The sea washes Cochin-china and Tung-quin to the east; the former has Tsiompa to the southward, and the latter the Chinese province of $\mathrm{Y}$ unnan to the northward of it. The whole comprehends about ninety-five thousand square miles.

Soon after Mr.Jackson's return to the Lion, the speedy departure of the squadron was announced to the officers of the Cochin-chinese government, which was followed by a complimentary message from the reigning prince, accompanied by a second present of provisions, particularly of rice, in such a quantity beyond what the squadron could consume, that a part of it was sent to the Company's factory at Macao. The Embassador, after proper compliments and thanks, signified his inten- 
Cochin- tion of returning to Cochin-china, if practicable for china. him, after he had been at the court of Pekin. The squadron sailed from Turon on the sixteenth of June, 1793. 


\section{CHAPTER IX.}

PASSAGE TO THE LADRONE ISLANDS, NEAR IACAO; AND THENCE TO CHU-SAN. TRANSACTIONS AND OBSERVATIONS THERE.

$F_{\text {Rom }}$ Cochin-china to the Chinese coast, the pas- Pasage to sage, when the south-west monsoon has regularly set in, $\begin{gathered}\text { the Ladron. } \\ \text { Istands. }\end{gathered}$ is generally short and easy. The expectation of coming soon in sight of a country, which was the object of so long a voyage, rendered the passengers still more inpatient to get to the place of their destination than they had been when much farther removed from it.

The port of Tien-sing, where the Embassador meant to land, was, however, yet at a considerable distance. It was intended previously to touch at one of the Ladrone islands, opposite to Macao, for the purpose of sending letters to Europe by any conveyance from that settlement, or Canton; but more particularly to receive any intelligence which might be interesting to the Embassy, as well as to get pilots, if any were to be found in that neighbourhood, for the Yellow sea, of which the navigation was entirely unknown to Europeans. This was not the case with regard to the track between Cochin-china and Macao; and therefore no pilots had been 

Passage to required from thence; however, few accurate accounts
the Ladrone

had hilherto been published of the navigation, either througl that track, or from thence to the Chu-san islands.

The mountain of Tien-tcha, or of new Gibraltar, which forms the harbour of Turon, prevented the ships, lying under it, from feeling much of the effect of the sea breeze. They waited, therefore, on the day of their departure, for the land wind, which always rises there in the afternoon. Its direction was from south by east to south-south-east, and it drove them above one hundred miles from Turon in the course of the first twentyfour hours. In that space it was found that a current had run in a direction north sixty-seven degrees west about thinty miles, or one mile and a quarter in every hour. Such a current there, at this time, was naturally to be expected. The tide flows from the eastward towards the shores of Cochin-china between the Paracels, mentioned in the last chapter, and a large island called Hai-nan; therefore as the water, returning from those shores, is too weak to counteract the constant eastern tide, it is forced along the inward trending coast, towards the northward, into the gulf of Tung-quin; from whence there is no outlet, except a narrow passage formed between Hai-nan and a long neck of land jetting from the continent of China. This passage being directly open to the east, the water brought by the constant eastern 
tide is thus hemmed into a gulf; and accumulating in Passage to vast quantities, occasions very high tides, and that ir- $\begin{gathered}\text { the Ladron. } \\ \text { Istands. }\end{gathered}$ regularity to which Sir Isac Newton has adverted in his works.

In the second day's course there appeared to be a small set by a current about eight miles north-east, caused, probably, by the reflux of the sea from the eastem coast of Hai-nan, to which the ships were opposite at noon.

On the third day, the nineteenth of June, a current set from the eastward thirteen miles, which might be produced by the influx of the tide through the neighbouring straits of Hai-nan, across the mouth of which the squadron passed that day.

On the twentieth of June were seen a high peaked island, called by Europeans the Grand Ladrone, and another near it, whose summit is more level and somewhat lower than the former; and the same day brought also the main land of China into sight, bearing north-north-east. Tho it was at such a distance as to prevent distinguishing more than that the land was high and of an unequal surface, having otherwise nothing peculiar in its appcarance; yet even this distant prospect left a cheerful impression on the mind; as if a point were gained that made an era in the history of the voyage.

On the twenty-first of June the ships came to anchor vor. I. ${ }_{3} \mathrm{C}$ 
Ladrone under the lee of another of the Ladrones, called Chook-

Islands. tchoo, in twelve fathoms water, the bottom muddy; the Grand Ladrone bearing west-south-west, distant three leagues, and Chook-tchoo south by west, three miles. The latitude of the Grand Ladrone appeared to be twenty-one degrees fifty-two minutes north, and the longitude one hundred and thirteen degrees thirty-six minutes east of Greenwich. The latitude of Chooktchoo twenty-one degrees fifty-five minutes north, and its longitude one hundred and thirteen degrees fortyfour minutes east. These longitudes are a few miles less easterly than the situation in which those islands are generally supposed to lie; but being deduced from a time-keeper that had been found to agree within a very few minutes of longitude, with the mean of several lunar observations, taken two days before, it is presumed they are nearly correct.

The margins, or rocks of the Ladrone islands next the sea, are of a black, or dark brown colour, owing to the action of the salt water. The spray and dashing of the waves upon them have corroded their surface in many parts, so as to give them an honeycombed appearance. There are some springs to be found upon those islands. The water is not brackish, nor has it any chalybeate, or other mincral taste. The soil upon the surface appears to be of the same nature with the component parts of the rocks below, and indeed is nothing else 
than the upper layer of the rock, decomposed and pulverized by the joint action of the sun and rain in the succession of ages. The rock consists of a mixture of clay, calx of iron in a small proportion, and a great deal of siliceous earth and mica. The sea all round is of a dirty yellowish muddy colour, and of no great depth. The bottom is mud and clay.

The Ladrones, and clusters of islands between them and the sonthern extremity of China, are so near to each other and to the main land, and are also so broken, as well as so irregular in their form and position, as to appear like fragments, disjointed from the continent, and from each other, at remote periods, by the successive violence of mighty torrents, or in some sudden convulsions of nature. Those fragments have now a very barren and unpromising aspect. In particular spots, indeed, there are some scattered patches of pleasing verdure; but, in general, little better than naked rocks appear; and scarcely a tree or shrub is visible among them. Those islands serve chiefly as retreats for pirates, and for the temporary abode of fishermen.

Sir Erasmus Gower observes, that "all the islands to "the eastward of the Grand Ladrone are steeper than "those to the westward. The former are high and un" even, and the depth of water among them is about "twenty fathoms. The latter are tolerably even, and, 
Ladrone " taken together, appear like a continued land; and the
Islands. Islands. "water among them is shoaler than among the former." The squadron being now upon the confines of China, and the Embassadior about to send messengers to Macao, application was made to his Excellency by two native Chinese, who had been companions of the interpreters, and to whom his Excellency had granted a passage in the Hindostan, that they might be taken ashore by the same opportunity. They conducted themselves throughout the voyage with great propriety. One of them, who was uncommonly expert in writing the Chinese characters, had usefully assisted in the translation of papers into that language, preparatory to the Embassador's arrival in China. His Excellency wished to make him a compensation for his trouble; but, tho he had no means of subsistence beside a very scanty allowance from Rome, no efforts were able to persuade him to accept money or presents of any kind. He considered himself as under much obligation, not only for the opportunity given him of returning to his country, but for the civilities shewn to him during the voyage. He felt both gratitude and esteem for the English nation; and ample justice would be done to its character in China, were his opinions on the subject adopted by his countrymen.

One of the interpreters wished also at this time to 
retire from the service of the Embassy. He began to be extremely apprehensive of being noticed by the Chinese government, in case he continued with the Embassador, as, by the laws of the country, he was liable to punishment, both for having left it without permission, and afterwards for accepting an employment from a foreigner. A greater firmmess of mind enabled his companion, the other Chinese interpreter, tho exactly in the same predicament, to adopt a very different determination. He considered himself as having entered into an engagement to accompany the Embassy throughout, and was not to be deterred from what he once had undertaken, by subsequent reflections upon the danger that might attend it. There was reason, indeed, to hope that the Embassador would be able to protect him, should it even be discovered that he had been born within the confines of the Chinese territories. He was a native of a part of Tartary annexed to China, and had not those features which denote a perfect Chinese origin; but his name having a signification in the language of that country, he changed it for one which bore the same meaning in English. He put on an English military uniform, and wore a sword and a cockade. He thought it right to take those precautions for his safety; but was prepared for any event that might take place; without being in the least disturbed about what it might be. 
Ladrone The other three Chinese embarked aboard the brigs for Macao, together with the persons who were sent by the Embassador for the purposes already mentioned. Dispatches from the government general of the Dutch East India settlements, to their resident in China, containing orders for his co-operation with the views of the British Embassy, were forwarded to him likewise at this time, as well as letters to the same effect from the cardinal prefect of the congregation for propagating the faith at Rome, to the procurator of the missions residing at Macao. The English factory was still also residing at that place, as none of the ships from Europe had yet arrived, that season, in the river of Canton.

Through the English East India Company's commissioners, the Embassador had information that, "his Im"perial Majesty's disposition to afford a reception to the " Embassy, suitable to its dignity, had not suffered the "least diminution, as appeared by his repeated instruc"tions on this subject to the different governments " upon the coast. He had given orders for Mandarines " to await his Excellency's arrival, and pilots to be pro" perly stationed to take charge of his Majesty's ships, " and to conduct them in safety to Tien-sing, as well as " to prepare for receiving the Embassador, and convey" ing him and his suite, to Pekin; concluding his com" mands with these remarkable words, that as a great "Mandarine had come so far to visil him, he must be received 
"in a distinguished manner, and answerable to the oc"casion."

The commissioners, who knew with how different a spirit foreigners were received and treated at Canton, entertained no doubt that " the governing officers of that "place had thrown a veil over the disposition and in" tentions of the Emperor towards Europeans, and that " nothing was so much wanting, or would be of such " singular advantage to the East India Company, as a "free and immediate communication between their "servants and the court of Pekin, should an opening " offer for obtaining it in the course of his Excellency's " negotiations. The Embassy did not, certainly, appear " to be agreeable to some of the officers of the govern" ment of Canton, who were perhaps apprehensive of "its consequences to themselves. The motives which "gave rise to the Embassy had been anxiously inquired " into by them ; and particularly by the Hoppo, or chief "officer of the revenue, and inspector of foreign trade " there, whose consciousness of having merited repre" hension for well known acts of his office, always con" nected in his mind the subject of complaint with the "views of the Embassy. The commissioners had no " doubt of every engine having been set to work by him, " to prevent the success of their proceedings with regard " to it; and when he found a flaw in their commission, " by their not having been deputed directly from the 
Ladrone "King of Great Britain, but being merely represen"tatives of the East India Company, he did not let slip "the occasion to perplex and oppose them by every ar"tifice in his power."

The Foo-yen, or Governor of Canton, was likewise still solicitous to discover the private objects of the Embassy; and aware that some of them might relate to persons from whom the commissioners would wish them to be concealed at this early period, he gave assurances to the commissioners that, "if they should disclose them "to him, he would confine the matter within his own "breast, and that of the Emperor." The commissioners very properly replied that "they were ignorant of any "views beside those which obviously occurred of pay" ing a just compliment to his Imperial Majesty, and of " cultivating his friendship; but that if there were any " other, they were undoubtedly confided to the Embas"sador alone."

It was perhaps in the hope of penetrating into those supposed intentions, and, if any such there were, of obstructing the progress of the Embassy, that the commissioners were repeatedly urged to write to the Embassador to stop at Canton, where all foreign vessels came, instead of proceeding to Tien-sing. And this was pressed with so much carnestness, that the commissioners found it insufficient for them to observe that " it was neither "their province to advise, or perhaps in the Embas- 
"sador's power to admit of, a deviation from the orders " he had rcceived upon that subject," and they thought it prudent to declare the utter improbability that any vessel, which might be dispatched fiom Canton for such a purpose, could fall in with the squadron having his Excellency on board. They were, indeed, after such a declaration, precluded from applying for pilots to go in search of the squadron, from the southern extremity of China; and therefore " requested only that such should "be in readiness at the port of Chu-san, in the province " of Tche-tchiang, and at that of Ning-hai, in the pro"vince of Shan-tung, both on the eastern coast of the "empire. It was probable also that pilots from those "ports would be better acquainted with the route to the "gulf of Pekin than those residing at a greater distance: " it happened also that Chu-san, the port first mentioned, " had in former times been visited by the Company's "ships, and could not easily be missed. Neither was " it unlikely that the expedition, if not the success of " the enterprize, would be secured by adopting that " mode, instead of bringing pilots to Canton, where their " integrity might be exposed to the influence and in" trigues of persons avowedly adverse to the Embassy." Notwithstanding the jealousy entertained by the other European factories, "some of them, the Dutch in par" ticular, had already, since the notification of the Em" bassy, availed themselves of the new influence of the vor. I. 
"English, to escape the usual impositions laid on fo"reigners, removing from Canton to Macao. Such was, " indeed, the impression made by that notification, on " the officers of government at Canton, that several new " impositions which had been attempted by the Hoppo, " in the article of customs, since the arrival of the com" missioners there, were immediately waved on their " resolute denial, without the usual inconvenience of " a delay in the shipping of teas. The complaints, " which the Hoppo suspected were to be preferred " against him, had produced of late, on his part, very " extraordinary instances of civility and forbearance." It was perceptible likewise, that the native agents and servants of the English factory felt themselves on firmer ground than formerly, and began to assert, without fear, the rights of their employers against the vexations to which they had hitherto been in the habit of submitting. an advantage arising from the fact, independently of the result of the Embassy, and implying a conviction, that there was now a channel open, by which remonstrances against oppression might find an easy way to the imperial throne.

The governor of Canton had been anxious to receive from the commissioners, a list of the presents which the Embassador had in charge to deliver to the Emperor; and it appeared that no small curiosity had been excited about them at the court of Pekin, which the governor 
was desirous of having the means to gratify. He had made it a necessary condition; alleging that " he could "not send the letter announcing the Embassador's ap"proach, with an offering to his master, without trans" mitting the particulars of it." The commissioners gave all the satisfaction they were able, in regard to what the Embassador was to bring with him; and accounted for their imperfect knowledge of the subject, from the circumstance of their having left England before many of the presents were provided. The importance which appeared to be thus attached to the nature of the presents, must be supposed to proceed not so much from avidity of gain, on the part of the great monarch for whom they were intended, as from the inference to be drawn from their rarity and value, with regard to the degree of consideration and respect in which he was held by the prince who sent them, in this first instance of a direct communication between the two sovereigns. The specimens of the arts and ingenuity of Europe, which had reached Pekin by other means, were sufficient to convey a very exalted idea of what might be expected from thence on extraordinary occasions.

The Embassador was informed also by the commissioners that "two of the native merchants of Ganton had " been ordered to hold themselves in readiness to pro" ceed to any part of the coast, on the report of his "Majesty's ships being arrived there with the Embas. 
Ladrone "sador, and in all probability to accompany his Exlslands. "cellency to court." It was supposed that they were intended to serve as interpreters, as well as to treat for any goods which might be sent with the Embassador for sale; but the commissioners being of opinion that, "the great concerns which those merchants had "with the Company, might be materially injured by " their absence," petitioned the government not to remove them from their business, adding " that the Em" bassador was already sufficiently provided with inter" preters, and that the Company had sent no goods for "sale in the ship which attended the Embassy, as she " was chiefly laden with the presents for the Emperor." These merchants, indeed, beside being but very imperfectly qualified as interpreters, were too great gainers by the connection, as it now stood, with foreigners at Canton, to be fond of furthering a measurc from whence they might apprehend a change; and, on the same account, they might even join in any intrigue against it at Pekin. It happened likewise that the journey, at that time, would have been attended with considerable injury to their private affairs. They aided, therefore, the petition presented in their favour, by no inconsiderable presents to some of the officers of the government of Canton; and they were excused from leaving home.

On occasion of former embassies, one of the missionaries dependent on the palace had been sometimes sent 
from thence to meet the Embassador and attend him to court; but a change of system, with respect to them, had lately taken place. For two or three years past, since the first accounts of the confusions in France, and the dissemination of principles subversive of tranquillity in government, were received at Pekin, the dread lest such principles should find their way into the East, had occasioned precautions to be taken against their introduction. Tho no determination was made to exclude foreigners from Canton, restrictions upon their conduct were enforced with redoubled vigilance; and tho missionaries were received in China, and even, as astronomers and artists, encouraged in the capital, their correspondence, from whatever part of Europe, was henceforward intercepted, in order to be examined; and tho no set of men could feel a greater horror of the revolution and subsequent anarchy, in the course of which, indeed, those funds in France, from whence stipends had been regularly remitted to them, were seized by the democratic rulers of the state; yet were they now, in some degree, mistrusted by the jealous and cautious government of China.

The preference, therefore, on the present occasion of communicating with foreigners, was naturally given by the Chinese to their own subjects. The Portugueze, indeed, of the dependent settlement of Macao, were, in some degree, considered in that light. The intimate 
Ladrone comnection, on the other hand, subsisting for a long

1slands. the latter to expect every friendly assistance from the former. But by the intelligence the Embassador received at this time, through an unquestionable channel, it appeared that their ancient policy, of endeavouring to exclude all other foreigners from China, still continued in its full force; and his Excellency had, at least, the early advantage of being thus apprized, that he was to depend chiefly upon the impression which his own conduct and that of his suite would make upon the Chinese, for removing any prejudices against the nation he went to represent, as well as for overcoming the difficulties that might be thrown in his way, during his residence in the country.

Soon after the return of the brigs from Macao, on the twenty-third of June the squadron weighed anchor from Chook-tchoo, and proceeded with a favourable gale towards the straits which divide the continent of China from the great island of Formosa, as it is generally termed by Europeans, but which among the natives, as well as the Chinese, is called Tai-wan. The same day the squadron passed between two small islands, one called Asses' Ears, from its forked aspect, the other termed Lema, botlı of them barren and uncultivated, and surrounded by large rocks, appearing above the surface of the sea. Those rocks, as well as the islands, seemed to be com- 
posed of solid granite. The situations of the islands, ascertained by meridional observations, and by the mean of several time-keepers, are,

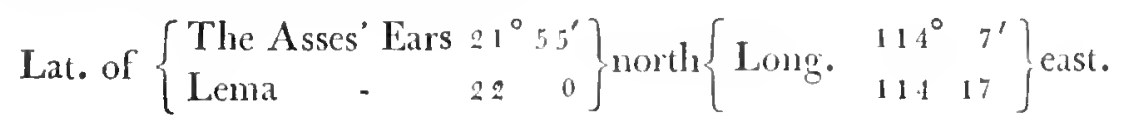

The next day, the twenty-fourth of June, a large elevated rock came in sight. It is perfectly white, and, on that account, is called Pedra Branca by the Portugueze, who having been the first European navigators in these seas, many of their names were adopted by their successors. The latitude of Pedra Branca is twenty-two degrees nineteen minutes north, and its longitude one hundred and fourteen degrees fifty-seven minutes east. Fahrenheit's thermometer at noon stood at eighty-four degrees, and the barometer at twenty-nine inches, seventy-three decimal parts. A current appeared to have set north by east during the last twenty-four hours, at the rate of about a mile an hour.

In the course of the next day, June twenty-fifth, the squadron crossed the tropic of Cancer; and the setting of the sun, that evening, was attended with an unusual degree of redness in the firmament. The quicksilver sunk suddenly in the barometer, and the wind increased to a fresh gale from the south-west. The next morning, still the twenty-fifth of June, according to the mode of reckoning time at sea from noon to noon, was ushered in with heavy squalls, rain, thunder, and lightning. Before noon 
Passage to it was almostcalm; but the sea remained agitated for some

Chu-san. time. The thermometer stood at eighty-two degrees, and the barometer at twenty-nine inches, sixty-three decimal parts.

The twenty-sixth of June was squally, accompanied by dreadful thunder, lightning, and ahmost incessant rain. The wind varied gradually from the south-east to south by west. The weather was so thick and cloudy that no observation could be taken the whole day; nor could the continent of China be distinguished, tho the squadron was now in the narrowest part of the strait between it and Formosa, and not distant from either much above ten leagues; and the land of both is so high, that, in clear weather, one can be seen from the other. The north-west part of Formosa was indeed perceived this day, for a few minutes, a little after sunrise, bearing from south-east by east to south.

In rainy weather the Ghinese sailors change their cotton clothes for jackets and trowsers, composed of reeds unbent and uncompressed, lying close and parallel to each other, together with large slouched hats of the same material, over the exterior surface of all which the rain slides off, as over the feathers of aquatic birds. This coarse but convenient covering very much resembles the dress worn, under similar circumstances, by the natives of the north-west coast of America. Tho it be possible that some original connection between the two countries, 
enabled the one to borrow from the other, it appears more probable that the same wants suggested to both the same contrivance.

If tolerable good weather might at any season be expected in this strait, it was most likely to be found in the height of summer, and about the middle of the monsoon; but from the situation and direction of the strait, it is probable that moderate weather seldom prevails there; for as it lies in a line with the north-east and south-west points of the compass, and is bounded on each side by ranges of mountains running in the same direction, the effect of the monsoons is increased by the compression which the air undergoes in passing through this narrow channel, which stands open, like a fumnel, to receive it from the two points whence the monsoons regularly blow. The currents, as might be expected, are found, invariably, to set with the monsoon; so that it may be considered as scarcely practicable for ships to work up against it. In the manuscript journal of the passage of the Argonaut through the strait of Formosa, towards the latter end of April, 1789, the title imports that it was "against the north-east monsoon;" but it appears from the journal itself, that the monsoon was then breaking up, the winds blowing from all points of the compass, and as often for, as against that vessel's intended course. Her small size, moreover, enabled her to run within many of the islands that lie off the coast of voL. I. $3 \mathrm{E}$ 
Passage to China, where she anchored from time to time, as occa-

Chu-san. sion required.

The squadron continued to have squally weather, chiefly from the westward, on the twenty-seventh of June, with almost continued heavy rain, and a cross confused swell of the sea; in the night the wind was variable; toward the latter part it blew chiefly from the north ward. The latitude by the reckoning differed sixteen miles from the observation at noon, and the longitude, by the chronometer, was fifty miles to the eastward of that by account; whence it was inferred that the current had rum, within these three last days, forty-eight miles in the direction of north seventy degrees east, or at the rate of two-thirds of a mile in every hour. The thermometer at noon was at seventy-nine degrees; and the barometer at twenty-nime inches, seventy-three decimal parts.

Duning the twenty-eighth of June the wind was moderate and variable, chiefly blowing from northerly points, a cross and heavy swell setting easterly. As soon as the squadron lrad cleared, or passed beyond the strait, a current, setting to the westward, seemed to rum against the heave of the sea, at the rate of upwards of hall a mile an hour. The weather being now apparenty more settled, the squadron made sail lor the islands lying off Cilu-san.

On the twenty-nimh the weather was hazy and unpleasant. The soundings decreased from filty-two to 
twenty-two fathoms. A cluster of islands came in siglit, called the Hey-san or Black islands, being little more than naked rocks. Their latitude is twenty-eight degrees fifty-three minutes north, and longitude one hundred and twenty-one degrees twenty-four minutes east. This cluster of islands lies a very few miles distant from the continent of China.

On the thirtieth the weather was thick and muddy, with moderate breezes from the south-west. In steering to the northward, the soundings increased regularly from twenty-two to thirty-two fathoms.

During the whole of the first of July the weather was thick and drizzling. The wind varied from south-west to south. Another cluster of islands were now observed called the Quee-san islands, close to which the squadron approached the next day, the second of July, and anchored in nine fathoms water, muddy bottom; the higl ${ }_{1-}^{-}$ est and most southern of those islands bearing north by west four miles. This island, called by the English Patchcock, is in latitude twenty-nine degrees twentytwo minutes north, and longitude, by chronometer, one hundred and twenty-one degrees fifty-two minutes east.

On the following morning, which was the latter part of the nautical day, the squadron weighed anchor, in order to stand in nearer to Chu-san, which they had somedifficulty in doing, on account of a vast number of Chinese boats 
Chu-san of different sizes crowding round them; the novelty of

Islands. European vessels having excited the most eager curiosity in the people of those boats. Above three hundred were reckoned about the Lion, wedged, as it were, one within another. But thousands were within sight, many employed in fishing; many of a larger size in carrying timber of different dimensions, and for various uses, as well as other articles of merchandize. Some of these moved forward in a line abreast ; some were lashed together, to receive timbers of uncommon size ranged across both decks: all of them were furnished with sails, of matting instead of canvas, and more fully manned than is usual in European vessels of equal burthen. The whole implying, beyond any thing hitherto observed elsewhere, a neighbourhood of extensive commerce, or abundant population.

Out of one of those boats the Hindostan procured a pilot, who was a man of some intelligence. He guided her, at first, between the Quee-san islands and the coninent, proceeding to the northward towards those other clusters of islands of different sizes, among the innermost of which is that of Chu-san. The only dinger in entering between the Quee-sans and the continent, is from a small rock, covered at high water, which appears to have been first seen from the ship Normanton, in the year 1736. In the manuscript journal of that voyage, it is described "to lie about sonth-west by west from 
"Patchcock, at the distance of four leagues; when it

" was discovered, the tide was at the first quarter of the

" ebb: when within four or five miles of the rock, it " did not appear larger than a ship's long-boat turned " bottom up; and as it was then at the dead of the " neap, it must be considerably under water in spring " tides." This rock may easily be avoided by keeping the Quee-san islands well aboard, or within a little distance; for there is not the least danger beyond a mile and a half to the southwasd or westward of them.

In the curious collection of charts published by Mr. Dalrymple, is one of the Chu-san islands, constructed by Captain Thornton. In that chart another rock, called the Holderness rock, on which a ship struck of that name, is laid down at more than three miles distance from the small island at the southem extremity of the great, or largest of the cluster of the Quee-sans, agreeably to the bearings and distances recorded in the log-book of that ship; but the Chinese pilot of the Hindostan knew of no such danger, so far from the shore. In the chart annexed to this work (No. 5, ) and altered from that just mentioned, the Holderness rock is laid down in its true position, according to the following bearings and distances, which were obligingly communicated by Thomas Fitzhugh, Esquire, at that time a passenger on board the Holderness, and now one of the directors of the East India Company. He observed that "the bearings were taken by him while the Holderness 
" lay on the rocks. Buffaloe's Nose, easternmost end

" north-north-west northerly. Southernmost small Quee"san, the body south-east. Second Quee-san, the peak " in the middle, south-east by east. Three small rocks, " of which two only are to be seen at high water, east"south-east half south. Third Quee-san, the body " east, distant one mile and a quarter. Northernmost " part of the Quee-sans, north-north-east. The largest " of the cluster called the Whelps, north-north-west " half west. The bearings recorded in the journal of "the Holderness were taken when at anchor afterwards, " at a distance from the rock."

The route, followed by the squadron, was between the Quee-san islands and a small cluster, named by the English the Bear and Cubs, lying to the westward of the Quee-sans and close to the continent of China. San-man, or the Whelps, were another group of islands lying to the northward, and in the middle of the passage towards Chu-san. Close to the westward of these the depth of water is five fatloms, and to the eastward seven. From them a north-north-west course leads between a cluster of small islands or rocks, surrounded with foul ground, called the Caulkers and Castle rock, and a small island to the eastward of them, called Kin-sa-hoia, or Starboard Jack, having a few rocks scattered on its southern side. In this part of the channel the bottom is very level; and accordingly an infinite number of boats with nets were 
occupied hereabouts, trolling, or dragging, the nets extended between two vessels, in every direction.

The same course leads between Buffaloe's Nose on the west side, and the Tinker on the east, to an island called Tree-a-top. This circumstance would be a sufficient distinction among islands which, tho covered with verdure to their summits, have very few trees growing upon them. No doubt this island deserved the appellation given to it when it was first described, together with the neighbouring isles, by the Europeans, above half a century ago, at which time they were permitted to trade to Chu-san; but the tree is gone, and this island, which is now as bare as those surrounding it, is only known by its relative position on the chart.

To the southward of Tree-a-top island about three or four miles, there is excellent anchorage, in five or six fathoms water, where ships are sheltered from every wind. There the Hindostan anchored; but the Lion and Jackall stood in between the Plowman and Buffaloe's Nose, on the former of which they took a supply of water; while the Clarence with Mr. Barrow, the Chinese interpreter, and two other gentlemen of the Embassy, were dispatched to Chu-san for the Chinese pilots, ordered to be in readiness there to conduct the squadron to Tien-sing.

Most of the Chu-san islands consisted of hills rising with a regular slope, and rounded at top, as if any points 
Chu-san or angles existing in their original formation, had been

Islands. gradually worn off into a globular and uniform shape. Many of those islands, tho close to each other, were divided by channels of great depth. They rested upon a foundation of grey or red granite, some part resembling porphyry, except in hardness. They were, certainly, not formed by the successive alluvion from the earth brought into the sea by the great river at whose mouth they were situated, like the numerous low and muddy islands, at the mouth of the Po, and many others; but should rather be considered as the remains of part of the continent thus scooped and furrowed, as it were, into islands, by the force of violent torrents carrying off, further into the sea, whatever was less resistible than the rocks just mentioned. Some of them wore a very inviting aspect; one in particular, called Poo-too, is described as a perfect paradise; this spot was chosen, no doubt, for its natural beauties, and afterwards embellished by a set of religious men, who, to the number of three thousand, possess the whole of it, living there in a state of celibacy. It contains four hundred temples, to each of which are annexed dwelling houses and gardens, for the accommodation of those monks. This large monastery, as it may be called, is richly endowed, and its fame is spread throughout the conpire.

During the absence of the Glarence, the Lion moored between the Plowman and Buffaloe's Nose islands, the 
former bearing north-west by north, and the north end of the latter north-east by north. This is a most excellent harbour, secure from all winds, and the holding ground so good that it required the whole strength of the ship's crew, with the assistance of every purchase, to weigh the anchors. The depth of water is from twelve to twenty-two fathoms. The tide in this spot rises about twelve feet, and runs at the full and change of the moon, two miles and a half an hour. Its latitude is twentynine degrees forty-five minutes north, and longitude one hundred and twenty-one degrees twenty-six minutes east. The Plowman's islands are inhabited, and contain several spots of beautiful verdure; but not a shrub, except a very few dwarf fruit trees, oak, and Weymouth pine. The rocks upon the Plowman's isles are of the same nature as those already mentioned on the Ladrones; but with the addition, in some parts, of perpendicular veins of white, and of blue and white, spar.

The ship was supplied from thence, at moderate rates, with bullocks, goats, and fowls; and from some of the surrounding boats, with a variety of excellent fish. The sight of a vessel of uncommon construction, as well as size, such as the Lion certainly appeared here, put, for a time, almost an end to labour by sea and land. Her decks were so crowded with visitors, and others were waiting with such eagerness to come on board, that it became necessary to dismiss, after a short visit, the vor. I. $3 \mathrm{~F}$ 
Chu-san first comers, in order to be able to gratify tle curiosity Islands. of others. Some of them entering into the great cabin of the Lion, where the Embassador had a portrait of the Emperor of China, immediately recognized it, and prostrating themselves before it, kissed the ground several times with great devotion; on rising, they appeared to feel a sort of gratitude towards the foreigner who had the attention to place the portrait of their sovereign in his apartment. Tho the ship's crew, at length, suffered many of them to range unnoticed and unaccompanied thro every part of the vessel, this indulgence was not abused by the commission of any act of impropriety. Among them few betrayed that awkwardness or rudeness of manners, or apparent vacancy of mind, so frequently observable among other people in the lower classes of life.

The Clarence in going to Chu-san, worked with the tide up Duffield's passage, where she was obliged to anchor when the ebb began. This passage is formed between the large island Lowang on the east, and a smaller, on the west, and is not above three miles wide; yet the depth of water is from one hundred to one hundred and twenty fathoms, and in the midst are several rocks, and two or three islets. The Clarence anchored in this passage, within a cable's length or half-quarter of a mile, from a small peninsula surrounded by a muddy bank, part of which was dry at low water; and the isthmus 
that connects it with the island Lowang is covered at high spring tides. At the edge of this bank the anchorage was in fifteen fathoms, the bottom soft mud.

The gentlemen, who were in the brig, were willing to employ the time that was to intervene, until the tide should turn in their favour for Cliu-san, in going ashore to pay their first visit to the territories of China. But it was not easy to effect a landing, as the Lowang shore was surrounded by soft deep clay and mud, wherever the bank ran out, and by steep rocks elsewhere. They found, at last, means to climb up the latter. From one of the neighbouring hills the passage in which the Clarence lay had the appearance of a river, while the sea beyond it might be considered as an immense lake studded with innumerable islands. The hill on which they stood was covered with strong grasses, reeds, and shrubbery, together with plants sufficiently denoting a situation remote from Europe. There were so few trees or cattle, that the country had the appearance of nakedness to an European eye.

Descending from the hill, they came to a small level plain recovered from the sea, which was kept out by an embankment of earth, at least thirty feet thick. The quantity of ground gained by it seemed scarcely to be worth the labour that it must have cost. The plain was, indeed, cultivated with the utmost care, and laid out, chiefly, in rice-plats, supplied with water collected 
Chu-san from the adjacent hills into little channels, through

Islands. which it was conveyed to every part of those plantations. It was manured, instead of the dung of animals, with matters more offensive to the human senses, and which are not very generally applied to the purposes of agriculture in England. Earthen vessels were sunk into the ground for the reception of such manure; and for containing liquids of an analogous nature, in which the grain was steeped previously to its being sown, an operation which is supposed to hasten the growth of the future plant, as well as to prevent any injury from insects in its tender state.

The party fell in with a peasant who, tho struck with their appearance, was not so scared by it as to shun them. He was dressed in loose garments of blue cotton, a straw hat upon his head fastened by a string under his chin, and half boots upon his legs. He seemed to enter into the spirit of curiosity, naturally animating travellers, and readily led them towards an adjoining village. Passing by a small farm house, they were invited into it by the tenant, who, together with his son, observed them with astonished eyes. The house was built of wood, the uprights of the natural form of the timber. No cciling concealed the inside of the roof, which was put together strongly, and covered with the straw of rice. The floor was of earth beaten hard, and the partitions between the rooms consisted of mats hanging from 
the beams. Two spinning wheels for cotton were seen in the outer room; but the seats for the spinners were empty. They had probably been filled by females, who retired on the approach of strangers; while they remained, none of that sex appeared. Round the house were planted clusters of bamboo, and of that species of palm, of which each leaf resembles the form of a fan; and used as such, becomes an article of merchandize.

The return of the tide put an end to this visit to Lowang, of which place one of the natives said that it was so considerable, and so well peopled, as to contain near ten thousand inhabitants.

The Clarence proceeding towards Chu-san, came in the dusk of the evening to a long projecting promontory, called in the chart Kee-to point. It is the extremity of a chain of mountains upon the Chinese continent, composed apparently of masses of granite. Round this point the tide ran in whirling eddies, with a rapidity that would force into its vortex a ship of the largest size, unless a strong breeze enabled her to sail past it. Within a hundred yards of the point, the mud is brought up from the bottom in such quantities as to excite alarm, lest the ship should strike the ground, in those who are not aware of the vast depth of water in this spot, which exceeds one hundred fathoms. A little to the southward of the point the Clarence found good anchorage, in seventeen fathoms, where it was thought 
Chu-san
Islands. prudent to remain that night, as the passages among the islands leading to Chu-san were narrow and intricate. In consequence of the regulations of the vigilant government of China, a report of her approach had already reached Chu-san; a Chinese vessel anchored near her, from which an officer came on board to announce that the next morning his barge should conduct the foreign vessel into the harbour of Chu-san, whither she was supposed to be bound. She proceeded with the early morning's tide, and after passing through several narrow straits, arrived in that harbour.

Between the Quee-sans and Ghu-san harbour, through a space of about sixty miles in length, and thirty in width, the number of islands exceeds three hundred. In the chart of those islands, already mentioned to be annexed to this work, is marked down the track of the Clarence in her passage to, and return from, the harbour of Chu-san. A dangerous rock, beside that of the Holderness, on which the Hindostan struck, on her return to the soutliward, is also marked upon it. By a perusal of the manuscript journals of the English EastIndia Company's ships which had sailed formerly to Chu-san, it appears that the Northumberland in the year 1704 , was the only one on board which it seems to have been known that such a rock existed. In her log-book it is observed that " they kept Kitto point " open with Deer island, to avoid a sunken rock that 
"lay off Sarah Galley island; which, and the flag-staft

" on Chu-san hill, being both in one, the ship is abreast "of it."

The part of the harbour in which the Clarence anchored, was distant about half a mile from a landing place, near the house of the Tsung-ping, or military governor, who presided in this place, and which bore from the brig north-east by north; the depth of water was five fathoms. In this situation the four passages into the harbour were so shut in, that none of them were visible. It looked like a lake surrounded by hills; and a person standing upon the deck of the Clarence at anchor, could scarcely point out how she got there. The small drawing in the plate (No. 5.) was taken on the spot. The extent of the harbour, from north to south, is little more than a mile; but it is near three miles from east to west. The rise and fall of the tides makes a difference of about twelve feet. The time of high water, at the full and change of the moon, appears to be about twelve o'clock. The tides, however, are very irregular, and vary according to the wind, and the eddies produced by such a multiplicity of islands. At the anchoring place of the Clarence the flood and ebb ran in the same direction, within three points of the compass, the current setting constantly between east and north-east by east; and for the two days and nights, during which that vessel continued in the harbour, her head always 
chu-san pointed nearly to the same object on the shore. The Istands. circumstance of irregular tides had been noticed in the manuscript journal of the Stringer galley, in the year 1708 , where it is mentioned that " in the distance of two " leagues among the Chu-san islands, the irregularities of "the tides were such that there was the difference of two " hours in the time of high water in the two places."

Among these numerous islands there are almost as many valuable harbours or places of perfect security, for ships of any burden. This advantage, together with that of their central situation, in respect to the eastern coast of China, and the vicinity of Corea, Japan, Leookeoo, and Formosa, attract considerable commerce especially to Ning-poo, a city of great trade in the adjoining province of Tche-tchiang, to which all the Chu-san islands are annexed. From one port in that province twelve vessels sail, annually, for copper to Japan.

Soon after the Clarence had anchored, some civil and military officers came on board to inquire the occasion of her visit; which being cleclared, it was settled that the party should go ashore the next morning, and wait on the governor to make their demand. Witl these officers came, to serve as an interpreter, a Chinese merchant, who had formerly been connected in trade with the agents of the East India Company, while they were allowed to frequent this part of China. He still retained 
somew hat of the English language. By this man's account the English had given no just cause of dissatisfaction in this place, tho they have been interdicted from it, through the means, as is most likely, of the superior influence of the officers governing at Canton, who are supposed to draw large sums from the accumulation of foreign trade in that port; and perhaps also from the increasing apprehension, on the part of the Chinese government, of the ill effects which might arise from an unrestrained communication between foreigners and the subjects of that empire, in several of its ports at the same time. The Chinese merchant still recollected with pleasure the names of Mr. Fitzhugh and Mr. Bevan, two of the Company's principal agents at Ning-poo and Chu-san; and indulged a hope that the English trade would be again permitted there. He explained the reason why a salute by the Clarence of seven guns was answered by three only from the shore, by observing, that among the regulations of economy in the Chinese government, no greater number is permitted to be fired from the same spot, on any occasion of compliment. This circumstance led him to mention their rule in saluting, to point their guns always into the air; adding, that if such a prudential caution had been practised by the English, the accident would not have happened at Ganton, when two Ghinese were killed by a shot from an English vessel on a rejoicing day, which endangered the continuance of the voL.I. 
Chu-san
Islands. Islands. ment of the gunner; the Chinese government taking it for granted, that guns pointed horizontally, must be really meant, whatever might be the pretence, for mischief.

As soon as it was known that the Clarence belonged to the Embassy, for the honourable reception and perfect accommodation of which orders, unexampled on the occasion of former Embassies, had been issued to all the provinces along the coast, the governor sent presents of all sorts of provisions on board; the next morning he received the gentlemen with great politeness, invited them to plays and entertainments, and expressed his hope that a formal deputation, which he had already dispatched to the Lion, lying at anchor at some distance, would prevail on the Embassador to come ashore, where preparations were making to receive him with all due honours. Thie earnest desire of repairing speedily into the presence of the Emperor, served as a full apology for declining to accede to any proposition which might tend to delay them, as well as for pressing him about pilots.

As to these the governor conceived that he had fully complied with the instructions he had received from court for that purpose, by having persons ready to conduct the squadron along shore to the next province to the northward, and that others would be found to conduct them, in like manner, successively, till they got 
to Tien-sing. It was, however, certain that coasting in this manner must be extremely tedious, and otherwise improper for large ships, drawing much water, as, near the shore, the risk of getting upon shoals, or striking upon rocks was greater than farther out at sea. This difficulty was stated to the governor, to whom the idea of a direct navigation to the gulf of Pekin, without any intermediate stop, was altogether new. He thought proper to consider of it till the next day.

The party, thus obliged to defer their return to the Lion, went to view the city or walled town of Ting-hai, situated within a mile from the large open village or suburb, built along the shore. The way from one to the other was over a plain, intersected with rivulets and canals in various directions, which possibly might serve, among other purposes, for that of separating the different properties of individuals. The ground was cultivated like a garden; not a single spot was waste; and the road, tho good, was narrow, as if in order that as little land as possible should be lost to culture.

The city walls were thirty feet high, and, like those of a large prison, overtopped the houses which they surrounded. Along the walls, at the distance of every hundred yards, were square stone towers. In the parapets were also embrasures, and holes in the merlons for archery; but there were no cannon, except a few old wrought-iron pieces near the gate. The gate was double; 
Chu-san within which was a guard-house, where military men Islands. were stationed; and the bows and arrows, pikes, and matchlocks, orderly arranged, were, no doubt, intended for their use.

Of the towns of Europe, Ting-hai bore the resemblance most of Venice, but on a smaller scale. It was, in some degree, surrounded, as well as intersected, by canals. The bridges thrown over them were steep, and ascended by steps, like the Rialto. The streets, which were no more than alleys or narrow passages, were paved with square flat stones; but the houses, unlike the Venetian buildings, were low, and mostly of one story. The attention, as to ornament, in these buildings was confined chiefly to the roofs, which, besides having the tiles that cover the rafters luted and plastered over, to prevent accidents from their falling in stormy weather, were contrived in such a form as to imitate the inward bend of the ridges and sides of canvas tents, or of the coverings of skins of animals or other flexible materials, effected by their weight; a form preferred, perhaps, after the introduction of more solid materials, in allusion to the modes of shelter to which the human race had, probably, recourse before the erection of regular dwelling houses. On the ridges of the roofs were uncouth figures of animals, and other decorations in clay, stone, or iron. The town was full of shops, containing, chiefly, articles of clothing, food, and furniture, displayed 
to full advantage. Even coffins were painted in a variety of lively and contrasting colours. The smaller quadrupeds, including dogs, intended for food, were, as well as poultry, exposed alive for sale, as were fish in tubs of water, and eels in sand. The number of places where tin-leaf, and sticks of odoriferous wood were sold, for burning in their temples, indicated no slight degree of superstitious disposition in the people Loose garments and trowsers were worn by both sexes; but the men had hats of straw or cane which covered the head, their hair, except one long lock, being cut short or shaved; while the women had theirs entire, and plaited and coiled, becomingly, into a knot upon the crown of the head, as is sometimes seen on the female statues of antiquity.

Throughout the place there was an appearance of quick and active industry, beyond the natural effect of a climate not quite thirty degrees from the equator: a circumstance which implied the stimulus of necessity compelling, or of reward exciting, to labour. None seemed to shun it. None asked alms. Men only were passing busily through the streets. Women were seen, chiefly, in the shops, and at their doors and windows.

Of most of the latter, even in the middle and inferior classes, the feet were unnaturally small, or rather truncated. They appeared as if the fore part of the foot had been accidentally cut off, leaving the remainder of the 
Chu-san usual size, and bandaged like the stump of an amputated 1slands. limb. They undergo, indeed, much torment, and cripple themselves in great measure, in imitation of ladies of higher rank, among whom it is there the custom to stop, by pressure, the growth of the ancle as well as foot from the earliest infancy ; and leaving the great toe in its natural position, forcibly to bend the others, and retain them under the foot, till at length they adhere to, as if buried in the sole, and can no more be separated.

Notwithstanding the pliability of the human frame in tender years, its tendency to expansion at that period must, whenever it is counteracted, occasion uneasy sensations to those who are so treated; and before the ambition of being admired takes possession of those victims to fashion, it requires the vigilance of their female parents to deter them from relieving themselves from the firm and tight compresses, which bind their feet and ancles. Where those compresses are constantly and carefully kept on, the feet are symmetrically small. The young creatures are indeed obliged, for a considerable time, to be supported when they attempt to walk; even afterwards they totter, and always walk upon their heels. An exact model was afterwards procured of a Chinese lady's foot, from which the annexed engraving has been taken.

This artificial diminutiveness of the feet, though it does not entirely prevent their use, must certainly cramp the 
quently found sufficient to surmount the common feelings of nature; and to many women a voluntary constraint upon the body and mind is, in some degree, habitual. They who recollect the fashion of slender waists in England, and what pains were taken, and sufferings endured, to excel in that particular, will be somewhat less surprised at extraordinary efforts made in other instances. Delicacy of limbs and person has, no doubt, been always coveted by the fair sex, as it has been the admiration of the other. Yet it could not be the extraordinary instance of such in any one lady, tho in the most exalted rank, according to the popular story throughout China, that could induce the rest of her sex to put at once such violence upon themselves, in order to resemble her in that respect. The emulation of surpassing in any species of beauty, must have animated vast numbers of all ranks, and continued through successive ages, to carry it at last to an excess which defeats, in fact, its intended purpose. Whatever a lady may have gained, by the imagined charms of feet decreased below the size of nature, is more than counterbalanced by the injury it does to her health and to her figure; for grace is not in her steps, or animation in her countenance.

While the party of Englishmen were engaged in gratifying their strong spirit of curiosity with regard to all the surrounding objects, they themselves were still more 
Chu-san
Islands. the occasion of surprise and astonishment in their beIslands. holders. Few of the people in this place had ever seen an Englishman before, or indeed any persons differing remarkably from themselves. They collected now in multitudes round the strangers, who were attended by a guard which the governor had ordered for them. The people, however, pressed close, without any apparent apprehension of the soldiery. They were familiar, but without insult, scoff, or uproar; it was then the month of July, and the crowd added to the sultriness of the weather. The party being dressed in the European style, their clothes fitted closely to their bodies, and some kept tight by ligatures, began to suffer exceedingly from the heat; while the surrounding multitude, in habits loosely hanging round them, felt no sort of inconvenience. The soldiers endeavoured to keep off the people by gentle methods, and sometimes by menaces, but did not seem in the habit of exerting against them the means of coertion in their hands.

The party took shelter from the heat and crowd in a temple full of monstrous and grotesque figures of the supposed deities and guardians of the city: and soon afterwards returned in sedan chairs, followed by new crowds. Before they reached the sea side, they were overtaken by heavy rain, and whirling gusts of wind that nearly overset the chairs, and forced them to go into a monastery of Chinese priests, where they were hospitably 
general growth, and injure the constitution of those who have been subjected to it. Some of the very lowest classes of the Chinese, of a race confined chiefly to the mountains and remote places, have not adopted this unmatural custom. But the females of this class are held by the rest in the utmost degree of contempt, and are employed only in the most menial domestic offices. So inveterate is the custom, which gives pre-eminence to mutilated before perfect limbs, that the interpreter averred, and every subsequent information confirmed the assertion, that if, of two sisters, otherwise every way equal, the one had thus been maimed, while nature was suffered to make its usual progress in the other, the latter would be considered as in an abject state, unwortly of associ-

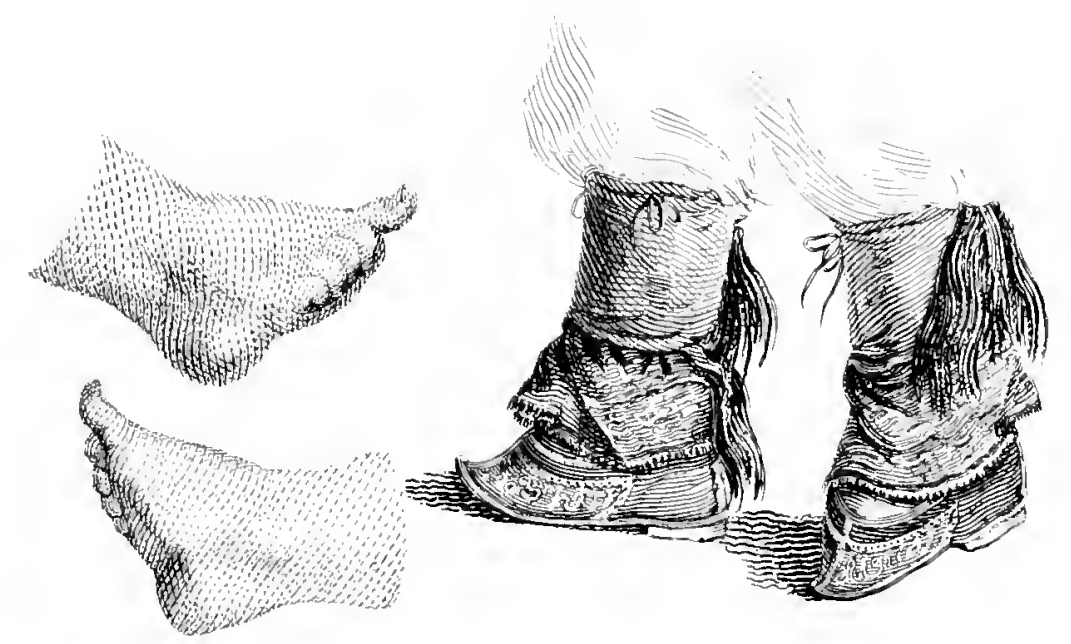


Chu-san ating with the rest of the family, and doomed to perpe-
Islands.

tual obscurity, and the drudgery of servitude.

In forming conjectures upon the origin of so singular a fashion among the Chinese ladies, it is not very easy to conceive why this mode should have been suddenly or forcibly introduced amongst them by the other sex. Had men been really bent upon confining constantly to their homes the females of their families, they might have effected it without cruelly depriving them of the physical power of motion. No such custom is known in Turkey or Hindostan, where women are kept in greater habits of retirement than in China. Opinion, indeed, more than power, governs the general actions of the human race; and so preposterous a practice could be maintained only by the example and persuasion of those who, in their own persons, had submitted to it. Men may have silently approved, and indirectly encouraged it, as those of India are supposed to do that much more barbarous custom of widows burning themselves after the death of their husbands. But it is not violence, or the apprehension of corporal suffering, but the horror and disgrace in consequence of omitting, and the idea of glory arising from doing, what is considered to be an act of duty, at the expence of life, which leads to such a sacrifice. In that instance, ages must have past to ripen prejudices productive of a consequence so dreadful: but the pride of superiority, and the dread of degradation, have been fre- 
received, and helped to tea, the general beverage served up on all occasions, and at all hours of the day.

The next morning the party presented themselves so early at the hall of audience, that the governor was not yet arrived there. It was a large building, situated at the end of a paved court, surrounded by galleries. The hall was open entirely to the roof, which was supported by several rows of large wooden columns painted red, and highly varnished, as were all the beams and rafters. A prodigious number of lamps, or lanterns, of various shapes and sizes were suspended by silken cords from the cross beams, and round the columns, decorated with tassels, varying in form and colour.

Of the lanterns, some were composed of thin silk gauze, painted or wrought in needle-work, with figures of birds, insects, flowers, or fruit, and stretched on neat frames of wood. Some were entirely made of loorn; these were so thin and transparent, that they were taken at first for glass, a material to which, for this purpose, the horn is preferred by the Chinese, as cheaper, lighter, less liable to accident, and, in case of accident, more easily repaired ; many of them were about two feet in the diameter, and in the form of a cylinder, with the ends rounded off, and the edges meeting in the point to which the suspending cords were tied : each lantern consisted of an uniform piece of horn, the joints, or seams, being rendered invisible, by an art found out by the Chinese: 
Chu-san among whom the vast number of such lanterns used in their dwelling houses and temples, as well as on the occasions of their festivals and processions, have led to many trials for improving their construction. The horns generally employed, are those of sheep and goats. The usual method of managing them, according to the information obtained upon the spot, is to bend them by immersion in boiling water, after which they are cut open and flattened ; they then easily scale, or are separated into two or three thin laminæ, or plates. In order that these plates should be made to join, they are exposed to the penetrating effect of steam, by which they are rendered almost perfectly soft. In this state, the edges of the pieces to be joined are carefully scraped and slanted off, so as that the pieces overlapping each other shall not, together, exceed the thickness of the plate in any other part. By applying the edges, thus prepared, immediately to each other, and pressing them with pincers, they intimately adhere, and incorporating, form one substance, similar in every respect to the other parts; and thus uniform pieces of horn may be prepared, to almost any extent. It is a contrivance little known elsewhere, however simple the process appears to be; and perhaps some minute precautions are omitted in the general description, which may be essential to its complete success.

The hall of audience furnished also another object of curiosity, striking at least to strangers. On several tables 
were placed in frames, filled with earth, dwarf pines, oaks, and orange trees, bearing fruit. None of them exceeded, in height, two feet. Some of those dwarfs bore all the marks of decay from age: and upon the surface of the soil were interspersed small heaps of stones, which, in proportion to the adjoining dwarfs, might be termed rocks. These were honeycombed and moss-grown, as if untouched for ages, which served to maintain the illusion, and to give an antique appearance to the whole. This kind of stunted vegetation seemed to be much relished by the curious in China; and specimens of it were to be found in every considerable dwelling. To produce them formed a part of the gardener's skill, and was an art invented in that country. Beside the mere merit of overcoming a difficulty, it had that of introducing vegetables into common apartments, from which, their natural size must otherwise have excluded them. According to the usual course of nature, different vegetable productions attain their perfect state in different periods, and after acquiring different dimensions, and passing through different stages of growth. Thus the cedar of Lebanon, for example, consumes some years in forming a tall and woody trunk, with many horizontal branches, before it emits its colourless flowers, and small cones, for the purpose of reproduction, which is the period of its perfection; while the hyssop, capable, at most, of raising a short herbaceous stem, produces its flowers and seeds the 
Chu-san season after it is sown. Some trees are reproduced, in-
Islands. Islands. deed, from cuttings of young branches, without the necessity of sowing any seed; but such cuttings, planted in the ground, must become trunks themselves in the usual period of their respective increase, and after acquiring their ordinary size, emit new branches, before they become adult, or capable of fructification : but by the art of dwarfing, an abscinded branch committed to the earth, continues still to fructify, as if it had been grafted upon a full grown tree, with its juices ripened for reproduction.

The general method of obtaining vegetable dwarfs is said to be the following: a quantity of clay, or mold, is applied to the upper part of the trunk of a tree, from which a dwarf is intended to be taken, and close to its division into branches. The mold is to be confined to the spot by coarse liempen, or cotton, cloth, and to be carefully kept moist by water. In consequence of this application, continued sometimes above a twelvemonth, small tender fibres shoot down like roots from the wood into the mold. The part of the trunk emitting those new fibres, together with the branch rising immediately above it, is then to be carefully separated from the rest of the tree, and planted in new earth, in which the fibres become new roots, while the former branch is now the stem of the vegetable, thus transformed in some measure. This operation does not destroy or alter the productive 
faculty which those parts enjoycd before their separation from their parent root. That which, while a branch of the original tree, bore flowers and fruit, continues to produce the same, tho no longer supported upon any stock. The terminal buds of such branches of trees as are meant to become dwarfs, are torn off; which circumstance prevents the further elongation of those branches, and forces other buds and branchlets from the sides. These branchlets are bent by wires to whatever form the operator wishes: and when the appearance of age and decay is meant to be given to a dwarf tree, it is repeatedly smeared with treacle or molasses, which attracts multitudes of ants, who, in pursuit of those sweet juices, attack the bark, and, by a gradual corrosion of it, produce the desired effect. These different processes are sometimes attempted to be kept secret by the gardeners, and they vary designedly in the mode of carrying them on; but the principle on which they are founded is sufficiently apparent from what is related here; and the contrivance argues ingenuity and perseverance, rather than the practice does true taste, which consists in assisting nature in its most favourite works; not in counteracting its operations, or distorting its productions.

While the party were receiving information on the subjects before them in the hall of audience, their attention was quickly called to the business that had brought them there, by the arrival of the governor. He was 
Chu-san accompanied by a civil magistrate. The latter was dis-

Islands. tinguished by a square embroidery upon his breast, in party-coloured silk, in which the figure of an imaginary bird, the phonix of the Chinese, was wrought; as was that of a tiger, on a similar embroidery, on the governor's robes, denoting his military functions. This latter animal is not inaptly emblematic of the evils which happen in the course of that profession; and a bird, in the ancient mythology of Europe, denoted wisdom, the proper quality of magistrates. These persons, with some subordinate officers, seated themselves in a row of arm-chairs, covered with Fnglish scarlet cloth, while the English were seated on a similar row placed opposite to them.

After an intercourse of civilities, tea was presented, and the magistrate then began a speech, which was uttered with a variety of tones, and accompanied with gestures, that implied it to have been intended for a display of eloquence, entirely thrown away, indeed, upon most of his auditors; but of which the purport was, that the mode of navigation from province to province along the coast had been, at all times, the practice amongst the Chinese, and must, consequently, be the best to follow in the present instance; that Chu-san was only a subsidiary port to the greater one of Ning-poo, and could supply no pilots, such as were now demanded. To this speech it was simply answered, that the greater size, and different construction of the English ships, 
required a different method to be followed in this respect than what usually was practised; that as Ningpoo might furnish such pilots as could not be found at Chul-san, they would immediately proceed thither in search of them.

This intention alarmed, instantly, the governor. He said that their departure for Ning-poo would imply, in the eyes of the Emperor, a dissatisfaction at their reception at Chu-san; the consequence of which, probably, would occasion the loss of his office and of his dignity, pointing to a globular red button, which he wore upon his bonnet, denoting the second class of magistrates, or officers, in the public service, of whom there are nine degrees; except which there is, strictly, no rank or dignity in the country.

The governor, to avoid the possibility of disgrace, immediately undertook to find out persons qualified to conduct the squadron in the desired route. Peremptory orders were instantly dispatched into the town for all such persons as were known to have ever been at Tiensing. As soon as they appeared, they were severally examined as to their skill in navigation. Two, at last, were found, who had traded frequently to that port; but who had quitted the sea some time. They gave information that the navigation of the Yellow sea was attended with no peculiar difficulty or danger, at least to vessels of the size that were generally used to traverse it ; 
Chu-san that there was a bar of sand across the mouth of the Islands. river Pei-ho, leading to Tien-sing, which prevented ships, that drew more than seven or eight feet water, from entering into it; but that within a day or two's sail of it, there was a safe harbour for larger vessels, under the island of Mi-a-tau.

These two men were commanded by the governor to prepare themselves to repair immediately on board the Clarence, in order to join the ships, and pilot them to that island, or as near to Tien-sing as they could go. Both these men were settled, and had families in Chusan. It was contrary to their inclination to be separated from them. They declared that their absence from home would be injurious to their private affairs. They prostrated themselves before the governor, supplicating him to excuse them from being employed upon this occasion. The English could not interfere without giving up all claim to pilots, and thereby risking the safety of the squadron and the Embassy; and the governor, declaring the Emperor's will must be obeyed, would listen to no remonstrance.

While the pilots went hastily to prepare themselves for this unexpected service, the gentlemen returned on board the Clarence to make ready for departure. They were scarcely arrived when they were followed by the governor, whose visit was influenced, probably, by curiosity, as well as civility. His attention was chiefly 
struck with the relative height of the masts, the contrivances for setting several sails upon them, one above another, and the dexterity of the sailors in rumning up the shrouds. The Chinese vessels liave indeed, sometimes, one canvas topsail over the mainsail. The latter is made of matting, across which, for its support, are sticks, placed parallel to each other, of the bamboo, a hollow wood, remarkable, at the same time, for strength and lightness. Up these sticks the Chinese sailors mount, when they find it necessary to go aloft ; but they generally carry on the manoeuvres of navigation upon deck.

During the stay of the Clarence in Chu-san harbour, one of the persons who came in her was seized with a violent cholera morbus, in consequence of eating too freely of some acid fruit he had found on shore. As no medical gentleman, nor any medicines happened to be on board, inquiries were made immediately for a Chinese physician to administer, at least, some momentary relief to the patient, then labouring under excruciating torments. A physician soon arrived; who, without asking any questions about the symptoms or origin of the complaint, with great solemnity felt the pulse of the left arm of his patient, by applying gently his four fingers to it ; then raising one of them, he continued to press with the other three, afterwards with two, and, at last, with only one, moving his hand for several minutes backwards and forwards along the wrist, as if upon the vol. I. 
Chu-san keys of a harpsichord, as far towards the elbow as the Islands. pulse could be distinguished. He remained the whole time silent, with eyes fixed, but not upon the patient, and acting as if he considered every distinct disease to be attended with a pulsation of the artery peculiar to itself, and distinguishable by an attentive practitioner. He pronounced the present complaint to arise from the stomach, as indeed was obvious from the symptoms, of which it is very probable he had information before he came; and which soon yielded to appropriate medicines, supplied, at the patient's request, by him.

As soon as the pilots arrived on board the Clarence, she stood out of Chu-san harbour, and, in her way to join the Lion, came close to an island, called that of Sarah Galley in the chart, when the wind dying away, she drifted into an eddy, in which she was whirled round, as upon a centre, several times, with much impetuosity. At every revolution the bowsprit was within a few feet of striking against a steep rock that rose perpendicularly out of the sea. The pilots, who had been in the same situation frequently before, were so far useful on this occasion, as to prevent any alarm being taken, by their assurance that no danger was to be apprehended; and, in fact, the tide soon carried the brig away from the whirlpool; and she anchored, the same night, off the northern point of Lowang. The following day she passed through the straits, marked Gough's passage 
in the chart, and joined the Lion at her place of anchor- Chu-san age, before described.

During her absence the deputation mentioned at Chusan, and another from the governor of the province, to the Embassador, had been on board the Lion. Presents of provisions were brought by both; and invitations given for his Excellency and his suite to partake of entertainments on shore, which he declined; alleging the necessity of the immediate prosecution of his voyage towards the Emperor's court. 


\section{CHAPTER $\mathrm{X}$.}

NAVIGATION THROUGH THE YELLOW SEA. EMBASSADOR'S ENTRANCE INTO THE RIVER LEADING TO TIEN-SING.

Navigation through the vatates $x$

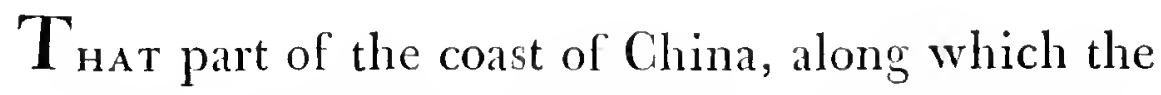
squadron had already sailed, from the eastern limits of Tung-quin to the Chu-san islands, measures upwards of one thousand nautical miles, each about a sixth longer than a common English mile. What remained of the Chinese coast from hence to the port nearest to Pekin, in the gulf to which that capital gives its name, is of an extent still more considerable. But at Chu-san the squadron was arrived at the utmost boundary of recorded European navigation. The sea from thence, for about ten degrees of latitude, and six of longitude, was utterly unknown, except to those who divelt in the neighbourhood of its shores. Into this sea are received the waters of the great Whang-ho, or Yellow river of China. This river wafts, in its long and circuitous course, such vast quantities of yellowish mud, that it takes, from that circumstance, and communicates to the adjoining sea, the particular name by which they are both distinguished. The Yellow sea is bounded by China, Tartary, and the peninsula of Corea. It was no immaterial_advantage 
derived from the Embassy, that it furnished an opportunity of exploring, without risk, so considerable a tract, under the guidance of those who had frequently passed through it. Of the two pilots obtained for this purpose at Chu-san, one was received on board the Lion; the other was sent to the Hindostan. Tho forced upon this service, they appeared ready to perform it, as well as they were able. When, indeed, an European pilot arrives upon the deck of a vessel, on board of which his assistance is required, he takes at once the helm, and exercises his functions like a dictator among the Romans, while all other authority is suspended, or exerted only to enforce obedience to his absolute commands. But the Chinese, in the present instance, were too much awed by the novelty of their situation, in the midst of strangers, to be forward in interfering. They were, however, attentive to the preparations made for the prosecution of the voyage, and to all the manœuvres of the ships. Each of them brought with him a small marine compass; but they had neither charts, nor any instrument for ascertaining latitudes. The local experience, it is true, of skilful pilots is deemed sufficient in regard to coasts visited by them frequently. It is not uncommon, however, on board Chinese vessels to have maps or sketches of their intended route, with the neighbouring headlands cut or engraved upon the back of empty gourds, the round form of which corresponds, in some sort, to 
Navigation the figure of the earth. Such a similitude may have through the sometimes contributed to render these sketches somewhat less erroneous; but the advantage is accidental; for neither the astronomers nor navigators of China have varied much from the first rude notions entertained among mankind that the whole earth was one flat surface; in the middle of which the Chinese took for granted that their own empire was situated; thence emphatically styled by them, the empire of the middle; all other countries surrounding it being, in their estimation, comparatively small, and lying towards the edge or margin of the earth; beyond which all must be a precipitate and dreadful void.

This ignorance of the earth's form precluded any attempt to ascertain the latitude or longitude of the different parts of it by observations of the heavenly bodies, for the improvement of navigation. Even among other nations, where philosophers had made discoveries of importance, they seldom were applied to useful purposes, until the great inventress of social arts, necessity, had stimulated to extraordinaryexertions. Notwithstanding the science of the Greeks, and the fertility as well as acuteness of their minds, they never proceeded to the length of ascertaining, witl the assistance of an instrument, the position of a ship at sea; satisfied that they could, by the observation, in the day time, of some part of the coast of the Mediterranean, in which they generally sailed, or of the 
many islands scattered through it, and, in the night time, of the stars, obtain such information as they wanted in

that respect. The Chinese, indeed, enjoy a similar adYellow sea. vantage, as their seas resemble the Mediterranean, by the narrowness of their limits, and the numerous islands with which every part of them is studded. It is to be observed, likewise, that the art of navigation, improved among Europeans, dates its origin nearly from the same period when their passions, or their wants, impelled them to undertake long voyages over the boundless ocean.

As to the compass, it is, among the Chinese, in universal use. With them the magnetic needle is seldom made to exceed an inch in length, and is less than a line in thickness. It is poised with great nicety, and is remarkably sensible; by which is meant, that it appears to move at the least change of position, towards the east or west, of the box in which it is suspended; tho, in fact, the nature of the magnet, and the perfection of the machine containing it, consist in the needle's privation of all motion, or its continuing to point always steadily towards the same portion of the heavens, however rapidly may be whirled the compass-box, or other objects surrounding it. This steadiness, in the Chinese compass, is accomplished by a particular contrivance, as observed by Mr. Barrow. "A piece of thin copper is strapped " round the centre of the needle. This copper is riveted 
Navigation through the Yellow sea.
" by its edges to the upper part of a small hemispherical "cup, of the same metal, turned downwards. The cup, "so inverted, serves as a socket to receive a steel pivot " rising from a cavity made into a round piece of light " wood, or cork, which thus forms the compass-box. "The surfaces of the socket and pivot, intended to meet " each other, are perfectly polished, to avoid, as much as "possible, all friction. The cup has a proportionably "broad margin, which, beside adding to its weight, "tends from its horizontal position to keep the centre of "gravity, in all situations of the compass, nearly in co" incidence with the centre of suspension. The cavity, " in which the needle is thus suspended, is in form cir"cular, and is little more than sufficient to receive the " needle, cup, and pivot. Over this cavity is placed a thin " piece of transparent talc, which prevents the needle from " being affected by any motion of the external air; but "permits the apparent motion of the former to be easily "observed. The small and short needle of the Chinese " has a material advantage over those of the usual size in "Europe, with regard to the inclination or dip towards "the horizon; which, in the latter, requires that one " extremity of the needle should be made so much hea"vicr than the other, as will counteract the magnetic "attraction. This being different in different parts of "the world, the needle can only be accurately true at "the place for which it had been constructed. But in 
"short and light needles, suspended after the Chinese " manner; the weight, below the point of suspension,

" is more than sufficient to overcome the magnetic power

" of the dip or inclination, in all situations of the globe; " and therefore such needles will never deviate from "their horizontal position."

Upon the upper surface of the box are drawn, as appears in the annexed engraving, several concentric lines or circles, according to the various sizes of the compassbox. This is seldom less than four inches in diameter. The circles are distinguished by different Chinese characters. Eight are marked on the first or innermost circle; four of which denote the cardinal points of east, west,

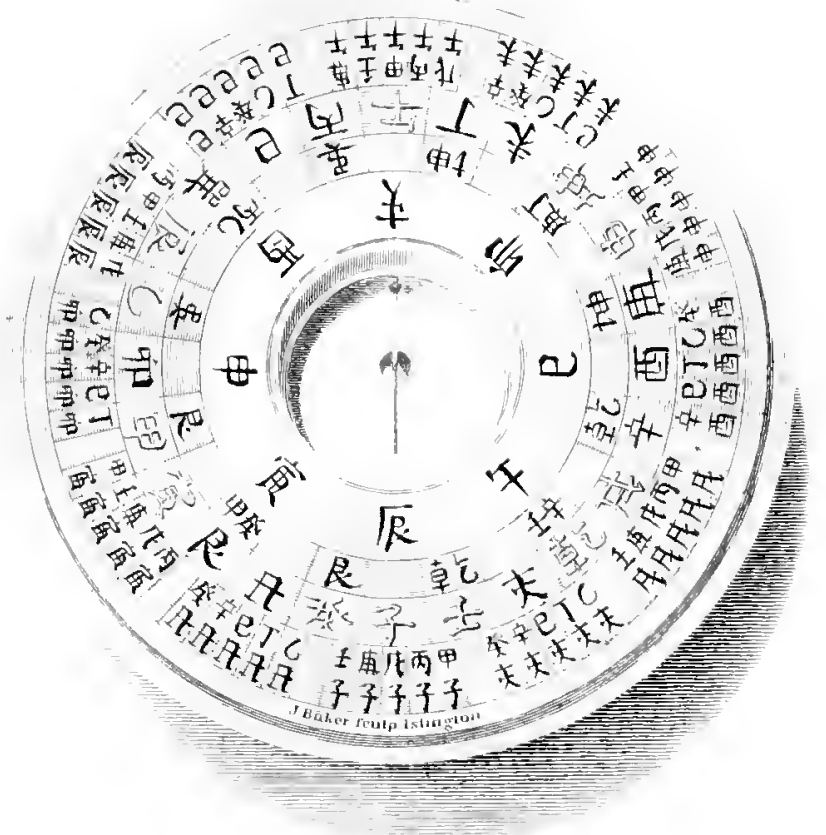


north, and south; and four the bisecting intermediate points. The same eight characters also signify eight equal divisions of the natural day, or space during which the earth revolves upon its own axis in pursuing its course round the sun, every such division being of three hours. The characters denoting those divisions are so placed as to point out nearly the position of the sun at those different portions of the daty, beginning at sunrise, of which the character means also the eastern portion of the heavens. With this fist circle of eight divisions agrees the first compass, which is said to have appeared in Europe in the beginning of the fourteenth century; and which, by subsequent subdivisions, was improved into thirtytwo points, as seamen became more expert and accurate in observation.

In another circle of the Chinese compass are twentyfour divisions, in cach of which a character is inserted, which marks, at the same time, a twenty-fourth portion of the heavens, and a twenty-fourth part of the natural diy. According to this division, each point, or twentyfourth portion of the compass, comprehends an integral number of fifteen degrees out of three hundred and sixty, into which all circles of the celestial splere have been agreed to be divided, probably since that early period when the number of days, in which the sun performed his apparent course, was supposed to be three hundred and sixty. 
The remaining circles round the Chinese compass contain the characters of the cycle of sixty years, by which this mation regulates its chronology, and other characters expressive of their philosophical and mythological doctrines, to which they are so attached as to render this instrument as familiar to the people ashore, as it is at sea.

The nature and the cause of the qualities of the magnet have, at all times, been subjects of contemplation among the Chinese. Their theory, in this instance, as in many others, is the reverse of that of European philosophers. It is obvious that while the magnetic needle, suspended by its centre, points at one extremity to the north, it necessarily looks, at the other, to the south; but each retains its own polarity; and, if turned round by force, will resume, when left at liberty, its original station opposite its respective pole. Thus the power, which principally attracts the needle, may be supposed to reside toward either or both portions of the earth. In Europe it has been thought that the needle has its chief tendency to the north pole; but in China the south alone is considered as containing the attractive power. The Chinese name of the compass is ting-uan-cling, or needle pointing to the south; and a distinguishing mark is fixed on the magnet's southern pole, as in European compasses upon the northern one.

The Emperor Caung-shee, grandfather to the present voL. I. 
reigning sovereign, who was in the habit of committing to paper his observations on a variety of subjects, and who, having encouraged learned missionaries at his court, had not been inattentive to their philosophical opinions, writes on this occasion, "I have heard Euro"peans say, that the needle obeys the north. In our "oldest records it is said, that it turns to the south; but " as neither have explained the cause, I see little to be "gained in adopting one opinion in preference to the "other. The ancients, however, are first in date; and " the farther I proceed, the more I am convinced of their " knowledge of the operations and mechanism of na"ture. Moreover, as all action grows languid, and " nearly is suspended towards the north, it is less likely " that the virtue, which gives motion to the magnetic " needle, should proceed from that quarter."

An allusion is made likevise to this property of the magnet, in the books of Chinese mythology, or fabulous portion of the history of that empire. It is there related, that in the reign of Chin-nong, a rebel, of the name of Tchoo-yoo, had found, in order the better to clude or confound his enemies, the means of creating, at his pleasure, thick fogs, and even utter darkness; to prevent the effect of which, the emperor invented a machine, consisting of a figure standing in a chariot, with one arm stretched out, and pointing always to the southward; which circumstance enabled the imperial troops to fol- 
low the proper track for discovering and overthrowing $\begin{gathered}\text { Navigation } \\ \text { through the }\end{gathered}$ the rebel.

The Emperor Caung-shee was well aware, however, that the needle does not always point directly, either to the south or north; and that this declination is not the same in all countries, nor invariable in the same place; but the sphere of Chinese navigation is too limited to have afforded experience or observation for forming any system of laws supposed to govern the variation of the needle. Their knowledge of the general polarity of the magnet answers every purpose, in practice, to that nation; and their researches upon most subjects seem to have been directed chiefly, and to be too often circumscribed, by the immediate prospect of utility resulting from the continuance of every particular pursuit.

The Chinese pilots had soon occasion to perceive how much more essential the perfection of the compass was to the bolder navigators of Europe, than to themselves, as the commanders of the Lion and Hindostan, trusting to that instrument, stood out directly from the land into the open sea.

The track of this voyage is laid down in the chart of the Yellow sea (being No. IV . of the large volume of accompanying plates.) On this chart, as well as in the general chart (No. I.) of the route from Europe, and return to it, is marked, beside the soundings, the state of the marine barometer, and of Falnrenheit's thermometer, in the 

Navigation shade, every day at noon. This precaution prevents the
through the Yellow sea. necessity of inserting those observations in the body of this work; but other details of so new a navigation as that of the Yellow sea cannot, with propriety, be omitted. The squadron entered into it on Tuesday the ninth of July. The weather was dark and cloudy. A thick fog covered the horizon. A heavy swell came from the eastsouth-east. The departure, or point from whence the progress of the squadron was to be computed, was the isle called Patch-cock, lying in twenty-nine degrees twentytwo minutes north latitude, and one hundred and twenty degrees fifty-two minutes east longitude. The ships, when sailing in six fathoms water, drew up the mud in such quantities, that each left in her wake a streak of yellowish brown for near half a mile: a circumstance, which, to persons not apprised of it, would be apt to create alarm, lest it should denote a sudden shoaling of the water.

Wednesday, the tenth of July. Thick, hazy weather, and a constant heavy swell from the eastward. The wind, during the former and middle part of the day, blew from the north-west to west. In the latter part, the weather nearly calm. In the morning, two islands were perceived, which the pilots called Tchin-san, and Shootong-yeng, bearing north-west by west, distant eight or nine leagues. Soundings from thirty-two to thirty-seven fathoms; bottom fine sand. 
Thursday, the eleventh of July. Light airs and calms during the first part of the day. In the evening, a breeze sprung up from the southward. At five in the morning, Yellow sea. two new islands, small and rocky, were discovered to the westward, seven or cight leagues distant. The pilots called those islands Pit-tcha-san and Te-tchong. Soundings at noon thirty-six fithoms.

Friday, the twelfth of July. In the beginning of this nautical day, the wind was at south to south-east, with a very thick fog. The water shoaled ahmost suddenly from thirty-six to seventeen fathoms. The bottom, grey sand, with black specks. The pilots observed, that the squadron was then opposite the Chinese province of Kiang-nan ; and that in the neighbourhood were large shoals, the approach to which was announced by the bottom being sandy. In the morning, the fog became so thick that it was scarcely possible to see from one end of the Lion to the other. It may be difficult to explain why a shallow sea should generally have the atmosphere over it foggy: but the fact has been observed likewise upon the banks of Newfoundland, and other places, covered with little water. Another circumstance took place, not, perhaps, more easily to be accounted for. In the shallowest parts, but where no land was visible above water, swarms of the dragon fly suddenly appeared about the ships, which, in deeper water, quickly disappeared.

Efforts were made to keep the ships together during 
Navigation throush the Yellow sea.

the fog, by firing guns in the way of fog signals; notwithstanding which, the Hindostan was separated this day from the rest of the squadron. Shortly afterwards, she perceived three large Chinese vessels, which, by choice or accident, had deviated from the usual system amongst them of sailing near the coast. The soundings hereabouts were found by all the squadron to vary so frequently and suddenly, that notwithstanding the presence of the pilots, it was thought expedient to proceed with uncommon caution, and even sometimes to lie to. The soundings throughout this sea never exceeded fortytwo fathoms: in the deepest water, the bottom was mostly muddy; and sand was found usually where the water shoaled. The pilots observed, that the thickest fogs accompanied the south-east winds, which lasted generally four or five days at a time.

Saturday, the thirteenth of July. The wind south-east, and weather thick, with very few clear intervals. The lead was cast every hour to ascertain the soundings.

Sunday, the fourteenth of July. The wind continued from the same quarter. This morning, the fog being for a time dispelled, several land birds appeared, and sea weed and bamboos were seen floating upon the water; together with other indications of being near land. A number of junks, or Chinese vessels, were likewise perceived steering different ways.

In the separate route of the Hindostan, she saw this 
day a small square rigged European vessel. A Chinese Navigation junk in the European seas would not lhave occasioned $\begin{gathered}\text { through the } \\ \text { Yellow sea. }\end{gathered}$ more surprise, had not an intimation been given from Macao, that the commissioners had sent from thence, before the squadron arrived in the neighbourhood of that place, a vessel with dispatches for the Embassador. It was the Endeavour brig, commanded by Captain Proctor. She had also on board a young man who could speak Spanish and Chinese; and meant to offer his services as an additional interpreter to the embassy. The Endeavour belonged to the East India Company, and had been employed, under the command of a gentleman of science of the name of $\mathrm{M}$ 'Cluer, in a voyage of observation and discovery thro the great eastern Archipelago, comprehended in what are called the Chinese seas, according to the liberal plan pursued, in many instances, by the India Company, of attending to the promotion of knowledge, in the midst of its commercial undertakings. Captain $\mathrm{M}^{\circ}$ Cluer was considered as a diligent and capable observer. He had either visited formerly the Pelew islands, or had formed an exalted idea of the climate, and of the disposition of the inhabitants, from the very interesting account which has been published of them by Mr. Keate, from the materials furnished by Captain Wilson. Captain M'Cluer determined to seek for that happiness in the Pelew islands which he considered, no doubt, as less attainable in a larger and more compli- 
cated, but, perhaps, a more corrupt, society. He had this project in contemplation for some time; and provided whatever he thought might be conducive to his comfort in his new residence. On his arrival there, he gave up his vessel to the gentleman next in command to him, and wrote a letter to his employers, assigning, among other reasons, for the step he had taken, the desire he felt of distinguishing limself by a conduct of which few examples had previously been afforded. He was well received by the natives of the Pelew islands, and honourable distinctions, with considerable authority amongst them, offered to him, which he declined: contenting himself with a moderate portion of land allotted to him; and better pleased to benefit the country of his adoption, by the advice which his superior knowledge and experience might enable him to give, than to exercise any command amongst them. Such a procedure was certainly as likely to secure to him the permanent attachment of the people, as the assumption of power would be to excite, in the course of time, jealousy and discontent. It is far, however, from being certain that no accident will happen to disturb the harmony subsisting at present between this hospitable race and their new guest; and that no change will take place in his own disposition, recalling those affections and partialities which attach most men to their original connections and ancicnt habits. 
Captain Proctor confirmed, in many instances, the fa- Navigation vourable accounts given of the Pelew islands by Gaptain Yellow sea. Wilson. So far from a ferocity of character, or even dislike of strangers, the inhabitants entertain those who come among them with the utmost kindness, and enrol some of the principal, as they did Captain Wilson and Captain Proctor, in the list of their nobility. The latter, who had visited some of the neighbouring parts of New Guinea, where, on the contrary, strangers are generally treated with inhumanity, is inclined to attribute so different a behaviour more to a sense of resentment for acts of treachery and cruelty exercised against them by foreign adventurers arriving upon their coasts, than to the predominance of bad qualities naturally inherent in their own character.

The Endeavour, which hadcalled at Chu-san, brought from thence such a pilot as was first offered to the squadron. He conducted her close to the Chinese shore with little danger to the Endeavour, as she drew but a few feet water. She passed near the island of Tsung-ming, opposite the river Kiang. This island, unlike those of Chu-san, is very low, and, to appearance, formed of earth brought down by the current of the river; between the mouth of which and the island, the water is extremely shallow. The land seemed to be gaining upon the water very fast; and it is not unworthy of notice, that in the map preserved in the ducal palace of Venice, supposed vol. I. 3 L. 
to be taken, (as far as relates to China) in great measure,

from the draught made by the celebrated traveller of that city, in the thirteenth century, Marco Polo, no traces are found of the island Tsung-ming, tho those of Chu-san, not much to the southward of it, are distinctly marked; whether it was at that period as yet so small, as not to be thought worthy of being noticed, or so low, as to be passed by him unobserved. If that island had, in fact, increased in any considerable degree in the space of five centuries only, it must have undergone, previously to that period, changes of an opposite kind. And it is not difficult to conceive that soft earth, gradually thrown out from the mouth of a great river, and deposited where the further impulse of the stream was resisted by the rising tide, might be liable to be put again in motion, and washed suddenly away by the force of some mighty torrent overcoming the obstacle that had been formed by the same river in its usual and gentler course.

In the neighbourhood of Tsung-ming, and along the coast of China, Captain Proctor met several small junks, with mandarines on board, cruizing about, by order of the Emperor, to find out and welcome the Embassador, ats well as to conduct him into port; but they seldom went out of the depth of two fathoms, not aware that the Lion, which had his Excellency on board, drew about double that quantity of water: so little had the people here any just idea of the size, or rather the construction, 
of English ships. Those of China, tho often of very considerable bulk, being more flat bottomed even than most Dutch vessels.

The Lion kept to the eastward of the track of the Hindostan, and nearer, tho not in sight of, the western coast of the peninsula of Corea, which stretches from Tartary in a southern direction. The peninsula of Shantung extends from the main continent of China so far to the eastward, as to reduce the breadth of the Yellow sea to forty leagues, or thereabouts, between the eastern extremity of Shan-tung and the opposite part of the peninsula of Corea.

Both divisions of the squadron had, on the fifteenth, the wind from the southward, attended, part of the day, with a fog. While it was clear, the Hindostan perceived a small cone-shaped island, called by the pilot Ka-té-noo; and, on the next day, came in sight of the rugged land of Shan-tung promontory, as well as of a small island to the southward of it. At this place, a slight current was observed to set to the northward. The longitude here was found by the mean of several observations of the distance between the sun and moon, to be one hundred and twenty-two degrees forty minutes east. The observed latitude was thirty-five degrees ten minutes north; from hence the Lion steered north by west by compass, until she got into the latitude of thirty-six degrees twenty minutes north. The water then began rapidly to shoal from forty to sixteen, 
fourteen, and twelve fathoms, there being a difference of two fathoms every quarter of an hour; the bottom sandy. Such a sudden shoaling of the water naturally occasioned apprehension. It was, however, calmed more by the reports of the brigs, which were kept going ahead, and constantly heaving the lead, than by the assertions of the pilots, whose ignorance of the English language made them sometimes pass for being ignorant of their business.

On the sixteenth the island which the Hindostan observed to the north-east, appeared at the same time from the Lion (being to the eastward) to the north-west. The ships and brigs all joined on Wednesday the seventeenth. They perceived on that day two headlands or capes, which, together with the island just mentioned, are likely to be the first lands made by ships navigating directly from the southward towards the gulf of Pekin; it was thought, therefore, by the commander of the expedition, desirable to ascertain their situation with exactness, and to give each a name, as appears in the chart now published with this work. These tliree points of land, with their latitudes and longitudes, are as follow:

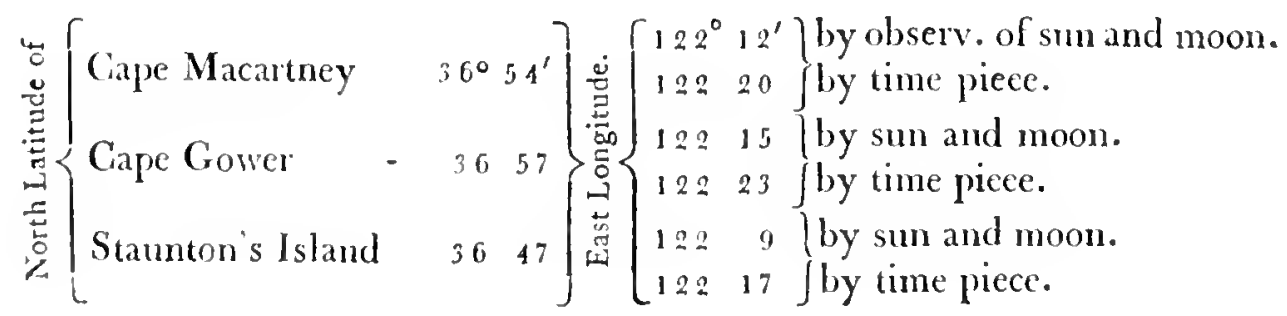


Gape Macartney, when bearing from north-north-east to north-west, has a remarkable appearance of six pointed peaks. With in this cape was an inlet, in which several Yellow sea. small vessels were descried at anchor. Near Cape Gower is a reef of rocks running out from a neck of land. The ground being foul, it was deemed prudent not to approach too near; but a snug harbour appeared to be within the low point, the entrance to which was between Cape Gower and the reef already mentioned. A great number of vessels were perceived within the harbour, behind which was seen a town of considerable extent.

Thursday the eighteenth of July. The wind for the most part, easterly, and the weather foggy. In the course of the aftemoon, the squadron passed another harbour, which was spacious, and contained several large junks. At this time the northernmost extremity of Shan-tung promontory bore north by west about eight leagues. When seen from this situation the highest and most projecting point of land appears in the form of an oblate cone, with its vertex elongated, as if on the summit were erected a spire or a pagoda; and it was familiarly compared to a mandarine's bonnet. Between Cape Macartney and the above point, the coast in general is bold ; and the mountains appear to extend far into the country. They were interspersed with beautiful vallies along the shore, highly cultivated, with inlets fit for the reception and security of flat bottomed vessels, such as those of the Chinese. 
Friday the nineteenth of July. The wind from eastsouth-east to north; the weather hazy. The squadron now considering itself as sufficiently clear of the Shantung peninsula, and having rounded the extreme eastern land of China, steered west by north. At midnight there was so very thick a fog that it was thought advisable to lie to. When, in the course of the following morning, it cleared up, the ships and brigs found themselves close upon a small rocky island, bearing somth-east half east two miles, and from a point upon the continent within it south-east half east five miles. Here is an appearance of a convenient liarbour, at least for vessels not drawing much water. Soundings, three miles from the shore, sixteen and eighteen fathoms; bottom soft mud.

The weather being now perfectly clear, the squadron made sail and stood to the westward, in a course parallel to the coast, at the distance of five or six miles. From the small island, last mentioned, the westernmost visible point of land is a remarkable cone-shaped hill, which terminates a range of broken mountains, distant from the island about eight leagues west by south. Part of this coast is rock y and barren, but in general it is level cultivated ground, terminating in a sandy beach. As soon as this last conical point was doubled by the squadron, a second came in sight, having near it a small hill, with a knob upon its top. Between these two points a course was steered nearly due west, 
within two or three miles of the shore, in seven or eight Navigation fathoms water. Vast crowds of people were here as- Yellow sea. sembled on the rising grounds to see the European vessels pass. Beyond the last point, the squadron got into a deep bay, which the pilots were understood to say was the harbour they had mentioned before they left Chusan, as fit to receive the squadron. But it was soon discovered, by the means of the people, whom curiosity had attracted from the shore, that this was the bay of $\mathrm{Ki}$ san-seu; and that the harbour of Mi-a-tau was in an island distant fifteen leagues farther to the westward, and differing in latitude a few miles only to the northward.

The bay of $\mathrm{Ki}$-san-seu is spacious, and well sheltered from every wind, except from east-north-east to eastsouth-east, being the direction of the entrance into the bay. It is shut in to the northward by a group of ten or twelve small islands, and a number of large rocks; and is inclosed by the continent on the western and southern sides. This bay extends from east to west at least ten miles, and nearly as much from north to south. Within it are two harbours; one behind a ligh bluff point, called Zeu-a-tau, which has four fathoms depth of water, and had in it a great number of Chinese vessels; the other behind a small projecting tongue of land, on the south-east side of the bay, in the mouth of a river called Ya-ma-tao. The number of junks perceived in almost every bay along this coast, indicates a considerable inter- 
change of commodities between this and other provinces of China. Such a circumstance, beside adding to the population by the many who are necessarily employed in carrying on this intercourse, introduces more of the movement and bustle of busy life, than is generally observed among the quiet tho industrious cultivators of the soil. Across the mouth of the river Ya-ma-tao is a bar, over which are only two fathoms and a half of water, but immediately without it, are four and five fathoms: the width of the river, from a quarter to half a mile. The country immediately behind the bay, though not very mountainous, has yet a barren aspect; and the inhabitants bear strong marks of poverty. Between Zeua-tau point and one of the islands to the eastward, forming the group already mentioned, there is a narrow passage, lying directly north and south, leading out of the bay of $\mathrm{Ki}$-san-seu, and through which there are eight, nine, and ten fathoms water close to the shore on either side; but near the eastern islands of the same group, there are small sandy keys, or banks, which are observed only when they are very near, as they are almost even with the surface of the water. The bluff point, or cape, of Zeu-a-tau is the cxtremity of a small, but bold and rugged peninsula, stretching to the northward. Along the centre of the great peninsula of Shan-tung, in the direction of east and west, ran a high range of mountains, the sides of which consist in 
great measure of a perpendicular and naked mass of Navigation granite.

A day was consumed in the bay of $\mathrm{Ki}$-san-seu; but on Sunday thetwenty-first, the squadron, alter being provided with new pilots, stood out through the passage between cape Zeu-a-tau and the islands, keeping nearer to the former than to the latter. A little to the westward of the most northern point of Zeu-a-tau, was a bay, into which several vessels were seen entering. And upon the original map of China, on a very large scale, constructed with great apparent accuracy, by the missionaries in the last century, and now in the possession of a great and revered personage, a convenient and safe harbour is here laid down.

The course, after clearing the east point, was northnorth-west for two miles; then north-west by north, north-west, and west, keeping the coast well on board all the way. After continuing thus till the evening, the squadron hauled round a projecting headland, very similar to that of the entrance of the bay of $\mathrm{Ki}$-san-seu. Here also all the rising grounds were covered with spectators. The hills behind the coast, along which the ships sailed this day, had a peculiar character, and appeared to be rather the effect of art than of nature. Their sides were rounded off as with the spade; and on the summit of each stood a small heap of earth, in form of a barrow, or ancient burying place.

yoL. I. 
After having hauled round this last projecting headland, another bluff point appeared due west from the former, and about eight miles distant from it. The shore between those two points formed a kind of bay, called Ten-choo-foo bay, which is open to the east and west, but partly sheltered in the northern quarter by groups of small islands, scattered about at different distances, from five miles to twice as many leagues, off the main shore. In the large chart last mentioned, those islands appear to extend two-thirds of the breadth of the sea in this part, leaving only a strait between the opposite projecting point of the province of Lea-tung, and the northernmost cluster of those islands. Among these were two islets, remarkable for the regularity of their form as truncated cones, and looking like glass-houses rising from the sea. They were, most probably, produced by the explosion from volcanos of matter of such light weight, and impelled with so moderate a force, as to continue where first it fell; and thus, gradually, to rise into a heap, assmming the regular figure just mentioned.

The squadron came to anchor, in seven fathoms water, in the bay of Ten-choo-foo, within two or three miles north-east of the city of that name. The anchorage was foul, with hard ground and shells. The Clarence was therelore immediately sent to examine the neighbouring lacubour of Mi-a-tiu, mentioned as a place of safety for 
the squadron. In the mean time, its arrival and pur- Navigation pose were announced by an officer to the governor of Yellow sea. Ten-choo-foo. The termination of this name denotes, in the Chinese language, that it was a city of the first order, having several middling and small towns within its jurisdiction. It was built on a rising ground, and appeared large from the ships' decks; and was fortified by a strong wall round it.

While Europe yet was barbarous, and individuals collected together for the safety of their persons and properties, the expence and difficulty of surrounding towns with fortifications, introduced, probably, the custom of building houses consisting of several stories, or floors, one above another, in order that the extent of the protecting wall might be the less considerable. The state of society must have been different in this part of China when the fortifications of Ten-choo-foo were erected; for they included no small proportion of ground not occupied by buildings; and either this city was expected to increase in houses to a number it has not yet attained; or the vacant space was allotted for military or other exercises or occupations.

The bay, or rather road, of Ten-choo-foo, not only is open to the eastward and westward, but is not well sheltered from the northward, the Mi-a-tau islands being too distant to break off much of either wind or swell from that quarter. The anchoring ground consists, in great 
part, of hard shary rocks; and at about a mile and a quarter from the shore, is a dangerous reef, covered at high water, extending nearly a mile east and west, round which the water shoals so suddenly as to render any approach to it very perilous. At Ten-choo-foo is constructed a kind of dock, or bason, for vessels to load or discharge their cargoes. The entrance into it is between two piers, and is from thirty to forty feet in width. The ground near the sea coast is richly cultivated, and rises in a gentle ascent, which is terminated by high, broken, and barren mountains apparently granitical.

The passage between Ten-choo-foo and the Mi-a-tau islands is called, in the chart, the strait of Mi-a-tau. The rise and fall of the tides in this strait are about seven feet. The flood tide runs east towards the sea, from whence it naturally should flow. The ebb, on the contrary, which properly is the reflux of the water into the sea, is here carried from it to the westward, into the gulf of Pekin. This extraordinary phenomenon does not arise from the position of the Mi-a-tau islands, whose size bears too small a proportion to the large surface of the sea, out of which they rise like so many points, to impede the progress, or change the direction, of the tide. A consideration of the northern boundaries of the Yellow sea may lad to a more satisfactory explanation. A strong tide, setting from the sonthward through the passage between the eastern promontory of Shan-tung and 
the peninsula of Corea, continues its northerly and impetuous course till impeded by the coast of Lea-tung. This

resistance forces it along that coast to the westward, and to the gulf of Pekin, where it follows the smooth sandy beach in a curve direction, according to the shape of the gulf, until it arrives at Ten-choo-foo, with a degree of strength sufficient to counteract, and even overcome, the weakened efforts of the eddy tide, setting round the projecting point of the Shan-tung province.

As soon as the governor of Ten-choo-foo was informed that the Embassador was on board the Lion, he sent to him a present, consisting of fresh provisions and fruit, and afterwards came on board to visit him. The governor was attended by a great number of persons; one of whom having had occasion to speak to him as he was passing along the ship's deck, immediately threw him. self upon his knees, and, in that posture, communicated his business, to the great surprise of the English spectators: a surprise that was heightened by the undisturbed countenance of the governor, as if accustomed to be accosted in that manner. This instance of the extreme distance between ranks did not seem, however, to proceed either from any particular haughtiness on the one part, or abjectness on the other; but indicated the respective disposition, brought about by forms, established for inducing habits of subordination in society. Such are considered, indeed, in China, as con- 
tributing more effectually to the prevention of tumult and disorder, than does the dread of punishment in other countries. Tho the meeting, even of equals, begins with much ceremony and mutual demonstrations of respect, yet these very soon give way to a free and familiar intercourse. The governor of Ten-choo-foo, in his interview with the Embassador, testified not only great politeness, but much ease and affability; and it was apparent upon this occasion, as well as from what was observed at Chu-san, that the solemnity of behaviour attributed, in many accounts of this country, as a general character, to the Chinese, was only an appearance assumed by them in the presence of those whom they considered as their inferiors.

The governor gave an invitation, which was declined, to the Embassador and his suite to entertainments and plays on shore, as indeed had done the governor of Chu-san, in order, in some small degree, to correspond, as they expressed it, with the splendid reception which it was understood their sovereign intended for his Excellency, when he should arrive at the imperial court.

The eclat of such a reception was, no doubt, likely to operate upon the minds of the people of China, who look with more than an ordinary degree of reverence to the throne. It might tend to impress them with a general sense of consideration for the English nation, of which 
the agents of the English East India Company at Canton might experience effects conducive to their benefit and comfort. Every consideration demanded, at the same tine, Yellow sea. that the individuals who composed, or accompanied, the Embassy, should, by the correctness and circumspection of their conduct, avoid giving offence, where it was so easily taken at any disorder or lightness of behaviour, and should endeavour, wherever they went, to gain upon the private good opinion of the Chinese; thus to counteract the prejudices which the Company's records testify to have been entertained in that country against the morals and manners of the English.

The Embassador determined, therefore, when the squadron was already advanced in the Yellow sea, and likely to arrive soon at its destined port in the gulf of Pekin, to disperse a paper throughont the squadron; which was publicly read to the crews and passengers of each vessel. His Excellency in this paper observed, that " it was impossible that the various important ob" jects of the Embassy could be obtained but through the " good will of the Chinese; that such good will might " much depend on the ideas which they should be in" duced to entertain of the disposition and conduct of " the English nation; of whom they could only judge "from the behaviour of those who came amongst them; " that the impressions which had hitherto been made " upon their minds, in consequence of irregularities 
Navigation through the Yellow sea.
" committed by some Englishmen at Canton, were un-

"favourable to the degree of their being considered as "the worst amongst Europeans; that those impressions "were communicated to that tribunal in the capital, "which reported to, and advised, the Emperor upon all " concerns with foreign countries; that it was therefore " essential, by a conduct particularly regular and circum"spect, on the part of those who belonged to, or were "connected with, the Embassy, to impress the Chinese "with new, more just, and more favourable ideas of "Englishmen; and to shew, even to the lowest officer " in the sea or land service, or in the civil line, that "they were capable of maintaining, by example, and " by discipline, due order, sobriety, and subordination " among their respective inferiors; that, tho the people " of China had not the smallest share in the government, " yet it was a maxim invariably pursued by their supe"riors, to support the meanest Chinese in any difference " with a stranger, and if the occasion should happen, to " avenge his blood; of which, indeed, there had been "a fatal instance not long since at Canton, where the "gunner of an English vessel, who had been very in" nocently the cause of the death of a native peasant, " was executed for it, notwithstanding the utmost united " efforts of the several European fictories at Ganton to "save him. Peculiar caution and mildness must conse"quently be observed in every sort of intercourse or ac- 
"cidental meeting with any, the poorest individual, of " the country.

"His Excellency, who well knew that he need not Yellow sea.

". recommend to Sir Erasmus Gower to make whatever " regulations prudence might dictate on the occasion, "for the persons under his immediate command, as he "hoped Captain Macintosh would do for the officers " and crew of the Hindostan, trusted also that the pro" priety and necessity of such regulations calculated to " preserve the credit of the English name, and the inte"rest of the mother country in those remote parts, would " ensure to them a steady and cheerful obedience; that " the same motives, he flattered himself, would operate " likewise upon all the persons immediately connected " with, or in the service of, the Embassy.

"His Excellency declared, that as he should be ready " to encourage, and to report favourably upon, the good " conduct of those who shonld be found to deserve it, so " he should think it his duty, in case of misconduct, or " disobedience of orders, to report the same with equal " exactness, and to suspend or dismiss transgressors, as " the occasion might require; nor, if offence should be " offered to a Chinese, or a misdemeanour of any kind be " committed, which might be punishable by the laws of "China, would he deem himself bound to interfere, for " the purpose of endeavouring to mitigate or ward off " their severity.

voL. I. 
"His Excellency relied on Lieutenant Colonel Ben-

"son, commandant of his guard, that he would have a " strict and watchful eye over the individuals that com" posed that body. Vigilance, as to their personal de"meanour, being as requisite in the present circum"stances, as it is, tho from other motives, in regard to " the conduct of an enemy in time of war. The guard " was to be kept constantly together, and regularly exer" cised in all military evolutions: nor were any of them " to absent themselves from on board ship, or from what" ever place might be allotted for theirdwelling on shore, "without leave from his Excellency, or their command" ing officer. None of the mechanics or servants were " to leave the ship, or usual dwelling on shore, without " leave from the Embassador, or from Mr. Maxwell: " and his Excellency expected that the gentlemen in his " train would show the example of subordination, by " communicating their wishes to him before they went "from the ship, or their usual habitation ashore. "His Excellency, in the most earnest manner, re" quested that no person whatever belonging to the " ships be suffered, and he desired that none of his " snite, guard, mechanics, or servants, would pre"sume, to offer for sale, or propose to purchase, the "smallest article of merchandize of any kind, under " any pretence whatever, without leave from him pre"viously obtained. The necessity of avoiding the least 
"appearance of traffic, accompanying an Embassy to "Pekin, was such as to have induced the East India

"Company to forego the profits of a new market, and

" prevented them from shipping any goods for sale in " the Hindostan, because the dignity and importance of " the Embassy, in the eyes of the Chinese, would be "utterly lost, and the good consequences expected from " it, even on commercial points, totally prevented, if " any actual transactions, tho in trifles, for the purpose " of gain, should be discovered amongst any of the per" sons concerned in conveying, or attending upon, an "Embassador; transactions, of which a report would "soon infallibly spread into that of a general system of " trading. From this strictness his Excellency would " willingly relax, whenever such advances should have " been made by him in negotiation as would secure the "object of his mission; and when a permission from " him to an European, to dispose of any particular ar" ticle of merchandize, should be considered as a favour "granted to the Chinese purchaser.

" His Excellency took that opportunity of declaring " also, that however determined his sense of duty made " him to forward the objects of his mission, and to watch, " detect, and punish, as far as in his power, any crime, " disobedience of orders, or behaviour tending to en" danger or delay the success of the present undertaking, " or to bring discredit on the English character, or occa- 
Navigation through the Yellow sea.

"sion any difficulty or embarrassment to the Embassy; "so, in like manner, should he feel himself happy in " being able, at all times, to report and reward the merit, " as well as to promote the interest, and indulge the " wishes, of any person who accompanied him on that "occasion, as much as might be consistent with the " honour and welfare of the public."

The reader, who may already wish to know the effect of such a paper upon the persons to whom it was addressed, will be gratified in hearing, not only that the Embassador thought himself justified in reporting very favourably of their general conduct, but that a mandarine of rank, who accompanied the Embassy throughout, declared before he parted from it, that the same number of Chinese taken from the different ranks of society, would not have demeaned themselves with so mucl quiet and decorum.

What further precautions might be necessary to be taken by the Embassador, previously to his entering China, would partly depend on the situation of the squadron while he should be absent from it. The first object was to know whether it could have a secure retreat in the harbour of Mi-a-tau. On the return of the Clarence from thence, the officer reported that " a reef of rocks, lying " off the east end of the easternmost of the Mi-a-tau " islands, called Chan-san, and stretching north-east by " north and south-west by south two miles, formed the 
" only eastern security of the bay before Chan-san. The "continent behind the city of Ten-choo-foo sheltered

" this bay, in some measure, from the southern, as the

" island itself did from the northern, winds. To the

" westward it was entirely open; and this bay was cer" tainly preferable to the anchorage off Ten-choo-foo; " but that the reef was a dangerous object, and should " not be approached nearer than where the soundings " were nine fathoms, as the water shoaled close to it "very suddenly. The Clarence anchored in this bay, " within a mile of the shore, in seven fathoms, in a clayey " holding ground. This island was about three miles in " length, and nearly as many in breadth; was well cul" tivated, populous, and commercial.

"The centre island was properly Mi-a-tau. Between " it and the former was a bay, of which the issues were "from the northward and southward, through passages " not more than a quarter of a mile in width, and free "from danger. This bay was safe, and sufficiently ca" pacious to contain near a hundred sail of vessels, of a " size small enough to anchor in three fathoms water; " the bottom was clayey, and consequently good holding "ground. This island was smaller than Chan-san, but " with a degree of population and culture equally great " in proportion to its size.

"Kei-san was the westernmost of that small cluster of " islands. It formed with the last, or proper Mi-a-tau, a 
"very good bay for vessels requiring not more than two " and three fathoms water. A dangerous reef of rocks off " the west point stretched north-east and south-west one " mile, and might be approached within a cable's length, "there being at that distance three fathoms water. That " reef formed the western security of the bay, and "must be kept to the left in entering into it. The low "ground on Kei-san was in a good state of cultivation, " with several considerable villages; but the hills were "quite barren. Opposite the high bluff westerly point, "were six fathoms and a half of water a mile from the "shore."

The report of the Glarence left no room to hope for any permanent shelter at Mi-a-tau for ships of such a size as the Lion and Hindostan, and took away from whatever confidence might have been placed in the Ghinese pilots, who had given so favourable a description of the harbour there. It was now determined by Sir Erasmus Gower, before the squadron should venture into the gulf of Pekin, of which the strait of Mi-a-tau might be considered as the entrance, to send an officer to examine particularly the mouth of the river which fell into it from Tien-sing, in order exactly to ascertain whether the ships might venture to it, and whether they could be in any place of safety, while it might be necessary to remain in its neighbourhood. The Jackall was dispatched for this purpose. She was, however, scarcely gone when a 
new Chinese pilot was recommended, as a person perfectly Navigation well acquainted with the gulf of Pekin, and river leading yellow sea. to Tien-sing. He was a man of a venerable aspect, plausible in his manner, and appeared to be skilled in nautical affairs. He asserted that there was an excellent harbourwithin six miles of the Pei-ho, or white river, which flows from Tien-sing, with plenty of water for ships of any magnitude; and in confirmation of the fact, drew a sketch of the place, with its relative situation in regard to the northern coast of the gulf, and to the mouth of the river. The road of Ten-choo-foo, where the squadron was then at anchor, was so unsafe thai there was little likelihood of changing for the worse, even if this new pilot's information should be incorrect. The determination was therefore taken, of entering without further delay into the gulf of Pekin.

In the afternoon of the twenty-third of July, the wind being easterly, and the weather moderate, clear, and pleasant, the squadron made sail, keeping the Mi-a-tan islands on the right. The sea coast to the westward, round the high bluff point of Ten-choo-foo, is perfectly flat, and was just visible from the deck. There is either a large inlet on this part of the coast, or a low island lying near it, for the masts of several junks were perceived rising from within the land. The Lion, on her return afterwards from the gulf, discovered an extensive reef stretching east by south and west by north for the distance of two miles, with three fathoms and a half of 

Navigation water upon the shallowest part, from whence the bluff
through the Yellow sea. head of Ten-choo-foo lay east by south eight or nine miles, and Kei-san island north by west. Soundings this day irregular, from twelve to nine, and then to fifteen fathoms; chiefly about twelve.

Wednesday the twenty-fourth of July. Moderate breezes from the south-east quarter, and fine clear weather. At three o'clock in the morning the water shoaled suddenly from fourteen to nine fathoms, and soon as low as six fathoms and a half. Presently afterwards the Clarence, which had been sent ahead, fired several muskets as signals of danger; upon which the ships wore round and stood off to the east-south-east. The surge beating upon rocks or shallow ground was heard distinctly. At six in the morning, when it was almost calm, a long range of low sandy islands was just visible, being little higher than the surface of the sea. At noon the extremities of these sandy islands bore by compass from west by north to north, the latter point distant about eight miles. On the easternmost island is a tall building erected, as the pilot mentioned, for the purpose of warning ships, in the night time, to keep clear of the sands with which those islands are surrounded.

Thursday the twenty-fifth of July. The wind south and south-westerly, light breezes and weather clear. The squadron stood to the westward under easy sail, inclining a little to the south ward, to keep clear of the low islands. The depth of water regularly decreased from fifteen to 
seven fathoms, when another small low island appeared bearing north, and distant about six miles. The squadron from hence stood on a western course till midnight, when tho the Lion's depth of water was six fathoms, the Clarence made the signal of danger. The ships consequently hauled their wind to the south-east, and deepened the water to ten fathoms; standing on this course about four miles, and then bearing away west-north-west four miles more, the depth of water was decreased to six fathoms and a half, when they came to anchor. The next day, twenty-sixth of July, it rained most violently during the forenoon; and in the evening there was, for several hours together, such a series of lightning and thunder, as few on board the Lion ever before remembered. The lightning seemed to overspread the sky with immeasurable sheets of livid flame, accompanied by continued vollies of thunder, that resembled the rolling fire of well disciplined troops at a review. The sea, however, remained perfectly smooth and unruffled by these concussions of the atmosphere; and the ships rode at single anchor all the time. Soon afterwards the Jackall was perceived returning from the westward. She was surrounded by an immense number of Chinese vessels, mostly standing also from the westward. The land was not yet visible from the Lion's decks, but the tops of trees and buildings were seen exhibiting a singular appearance, as if perched up in the air. From the mast heads, however, a very VOL.I. 
Navigation low and sandy beach was discovered above the surface

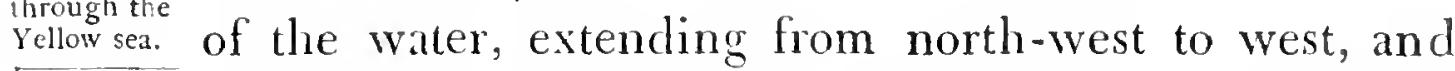
distant from the ship at least four leagues. Lieutenant, now Captain, Campbell, who had been sent in the Jackall to explore the coast found that "the river Pei-ho which "comes from Tien-sing was distant fifteen miles from "the present anchorage of the squadron; that a bar " crossed the mouth of the river stretching north-north" east and south-south-west, over which, at low water, " the depth was not more than three or four feet, and " which in many places, was almost dry; that the tides "rose and fell six or seven feet at the mouth of the "river; and that the time of high water, at the full and " change of the moon, was about half after three; that "five or six miles outside the mouth of the river a large " bamboo beacon was placed upon the bar, with some " of a smaller size, continued nearly in a straight line to " the shore; which were intended to serve as marks to " direct vessels entering into the river; it being meant "that these beacons should be kept close on board, and " to the lurboard or left hand side. That a course of west "by north, according to the compass, led up the best " channel, in a line with a fort which stands on the south " west side of the entrance into the river, which at its " mouth was about one-third of a mile in width, and three "fathoms in depth at low water ; that the city and port " of Tien-sing was reported to be thirty or forty miles 
"by land, from the mouth of the river, and twice as far

"by water." As to the promised harbour of the pilot,

not the least traces of it were to be discovered; except Yellow sea. that there might be some shelter behind the low sandy islands against the swell of the sea ; tho little against the winds. The situation of these islands agreed, indeed, exactly with the sketch which had been given by the pilot; and behind them were perceived the masts of many junks. The place, hovever, was not examined, from the little hope that was entertained of finding any security for large ships there. A very slight view of the land surrounding the gulf was sufficient to shew that no secure harbour was likely to be found upon its shores. A good harbour is generally formed by the means of massy rocks, or at least of high and considerable mounds of compact earth, thrust forward by some irregular operation, or in some convulsion, of nature; and leaving within them an inlet of the sea, which those projecting points may protect from the violence of the winds and waves: whereas the country which terminates this gulf is utterly devoid of any solid and elevated masses capable of becoming a bulwark, behind which there might be a safe retreat for shipping. Instead of such a bulwark nothing is seen but a low and level surface, the natural effect of a gradual deposition of soil washed down from the interior mountains, which soil fills up every original inequality, and meets afterwards in a regular line, the 
Navigation through the Yellow sea.

open sea, where no shelter is afforded. A part, no doubt, of the waters falling from the mountains is collected into streams which swell, by their union, into rivers; but the motion which had been acquired by such waters, in their descent from the heights, will, in some degree, be afterwards retarded, according to the extent of flat country which those rivers have to traverse. The land appearing to gain gradually here upon the sea, and consequently the extent of flat country being upon the increase, the river may be supposed to lose somewhat of the force with which it used to carry and disperse into the gulf the earth it had brought with it from the mountains. This earth is at length accumulated a little below the river's mouth, and forms the bar which crosses it completely.

The bar does not, however, materially obstruct the navigation of Chinese ships. There are many, indeed, here of three or four hundred tons; but they are constructed with bottoms so shallow and flat, and with upper works so light, that several passed over the bar into the river, while the Jackall, of about one hundred tons, with much difficulty, could follow them; the latter being built for navigating with the variable and frequently adverse winds of the European seas; and drawing, on that account, double the quantity of water, or, in other words, sinking to double the depth of junks, or Chinese vessels of equal burden. The inconvenience of falling much to leeward with a side wind, to which the flat- 
bottomed vessels of Europe are liable, is not very much Navigation felt in the Chinese seas, where vessels sail generally with through the the monsoon directly in their favour. The sails, too, of Yellow sea.

Chinese junks are made to go round the masts with so much ease, and to form so acute an angle with the sides of the vessel, that they turn well to windward, notwithstanding the little hold they have of the water.

Mr. Hiitner, the foreigner mentioned in the second chapter of this work, and who accompanied Captain Campbell in this expedition in the Jackall, reported that " he saw, on entering into the river, a vast number of " junks, all crowded with people, many of whom were " probably attracted by the novelty of an European ves"sel under sail. On board such of the junks as were " conducted with oars, the sailors were animated by a "very melodious song, begun by the helmsman, and " answered by the rowers. It was not merely an amuse" ment, but served to render the motion of the oars more " equal, and to fix the attention of the men that used " them. The Jackall was soon accosted by Chinese sol" diers in a boat, desiring her to anchor, and wait the " arrival of a mandarine, who had inquiries to make about " her. This gentleman made his appearance presently, " with several attendants, upon the Jackall's deck. As "soon as he was satisfied that she belonged to the ex"pected Embassy, he made many inquiries about the "Embassador, and the presents brought for his Imperial 
"Majesty. As the answers were general, he, after a Yellow sea.

" little time, endeavoured to obtain a more particular " account by changing the manner and form of his " questions; and he seemed to exert no little address to " obtain his object. Tho the motion of the brig and " smell of the tar were offensive to him, yet he con" tinued long on board to collect information as to the " size and strength of the ships attending the Embassa" dor, and the number of men and guns on board; while " one of his attendants was busy writing all the time of " the conference, as if taking notes of every thing that " passed. The mandarine concluded by declaring, that " the Emperor had issued orders for the reception and " accommodation of the Embassy, and offered to supply " whatever might be wanted. The brig being obliged " to wait in the river for the return of the tide next day, "Captain Campbell and Mr. Hiitner were invited on " shore, where they were hospitably treated; but in a " manner cross-examined, and the former questions re" peated to them. Particular inquiries were also made " as to the species of nutriment to which the Embassador " and his suite had been accustomed, and how his Ex" cellency wished to travel, observing that gentlemen in " China travelled either in sedan chairs, or in two " wheeled carriages by land, or in commodious boats by " water; which latter method was generally preferred " wherever practicable; but adding, that his Excellency 
" and his suite were to be accommodated whichever " way they wished. The mandarines spoke also about Navigation through the

" the articles of merchandize which they supposed were Yellow sea.

" brought for sale to Pekin, and said they might be safely " deposited in the four Ghristian churches in that city, " where they might be sold to great advantage. The " idea of trade was so associated with that of Englishmen, " in the minds of the Ghinese, who knew them only as "venders and purchasers of goods, that they could "scarcely give credit to the assertion, that the persons "composing the Embassy were not merchants, and "that ships of war never carried goods for sale, or "that there was little, beside what was intended for " presents for the court, in any of the vessels. The pro" posal, made with so little ceremony, of converting " churches into shops for the retail of merchandize, "which appeared singular to an European ear, was per"fectly familiar to the Chinese, whose places of worship " are occasionally made to answer every purpose of " utility to which they may be applied. The building " in which this conversation took place was itself a "temple; and in the crowd were some of the bonzes or " priests who ministered in it, and were remarkable for " the contrast between their grey beards and their robes " of rose-coloured silk.

"The mandarines, who were informed that the Eng"lish ships could not cross the bar, immediately con- 
Navigation " ceived their size to be immense, and formed a proporYellow sea. " tionate idea of the quantity of presents necessary to "fill them. They gave orders for preparing junks to "bring those presents, as well as the passengers and " baggage, on shore. A considerable building near the " river's mouth was provided for the reception of the "Embassador, where it was expected he would remain "some days to recover from the fatigues of so long a "voyage. And it was observed, that he need not pre" cipitate his journey to the capital, as the Emperor's " birthday was yet at a considerable distance. These " people not imagining that an embassy could be any " thing more than a visit or message of high compliment "to their sovereign on that anniversary, or on the occa" sion of some other solemn festival."

Mr. Hiitner was not long returned to the Lion when several Chinese vessels appeared with live-stock, fruit, and other vegetables in such profusion that the ships could only contain a part, and the overplus was necessarily sent back. It may not be uninteresting to see the list of what was sent at once. Twenty bullocks, one hundred and twenty sheep, one hundred and twenty hogs, one hundred fowls, one hundred ducks, one hundred and sixty bags of flour, fourteen chests of bread, one hundred and sixty bags of common rice, ten chests of red rice, ten chests of white rice, ten chests of small rice, ten chests of tea, twenty-two boxes of dried peaches, 
twenty-two boxes of fruit preserved with sugar, twentytwo chests of plums and apples, twenty-two boxes of ochras, twenty-two boxes of other vegetables, forty Yellow sea. baskets of large cucumbers, one thousand squashes, forty bundles of lettuce, twenty measures of peas in pods, one thousand water melons, three thousand musk melons, beside a few jars of sweet wine and spirituous liquors; together with ten chests of candles, and three baskets of porcelaine. In the same plentiful and gratuitous manner were provisions constantly supplied, without waiting for being demanded. The hospitality, and indeed the attentions of every other kind, which the Embassy and squadron experienced on all occasions, particularly at Turon bay, Chu-san, Ten-choo-foo, and here, were such as strangers seldom meet, except in the eastern parts of the world.

Two mandarines of rank, appointed by the court, one in the military and one in the civil service, with a numerous train of attendants, approached the Lion to pay their respects to the Embassador. These mandarines, it seemed, had never been before upon salt water. They had never seen a ship of the Lion's construction, bulk, or loftiness. They were at a loss how to ascend her sides; but chairs were quickly fastened to tackles, by which they were lifted up, while they felt a mixture of dread and admiration at this easy, rapid, but apparently perilous, conveyance. In their anxiety to fulfil their duty vol. I. 
Navigation through the Yellow sea. in paying this early visit, they had crossed the bar in the first sea junk they found, which was little prepared or calculated for such passengers, being crowded, dirty, and uncomfortable. On leaving it, they were the more forcibly struck with the orderly, as well as martial, appearance upon the Lion's deck ; the size and elegance of the great cabin fitted up for the Embassador, into which they were introduced, as well as the multiplied conveniences throughout the ship. They congratulated his Excellency, in the Emperor's name, and in their own, on his safe arrival, after traversing so great a portion of the ocean; they told him they were appointed to attend him to the imperial court; that it was the express will of their sovereign, and their own disposition, as indeed it proved, to render his journey safe and agreeable to him. Their conduct throughout deserves that they should be introduced with particular notice in this work. The civil mandarine was a man of grave, but not austere, manners. His demeanour indicated a plain and solid understanding. He was not forward in discourse; neither appearing to aim at any thing brilliant in himself, nor to be dazzled by it in others. A faithful and benevolent discharge of his duty seemed to be the sole and simple object of his pursuit. He had been preceptor to some of the imperial family; and was considered as a man of learning and judgment. He bore the honorary distinction of a blue globe, placed upon the bonnet covering his head. All mandarincs, or 
persons vested witl authority, from the frrst minister to the lowest constable, are divided into nine classes, and bear, in like manner, small globes or balls upon their

bonnets, but of different colours and materials, and are distinguished, besides, by appropriate dresses, in order to point them out to the people and to strangers, and to secure, at all times, a proper respect to their persons, and due obedience to their orders. This mandarine had

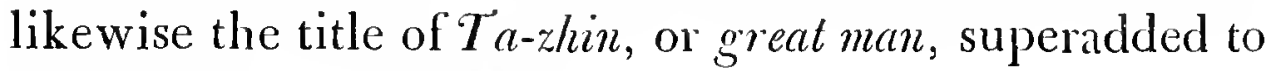
his family name of Chow.

The military mandarine who accompanied Chow-tazhin was in the true character of his profession, "open, bold, and brave." His name was Van, and he, in like manner, was styled Van-ta-zhin, or Van the great man. Beside a red globe above his bonnet, he was honoured with another mark of favour for his services. This was literally a feather, and taken from a peacock's tail. It was given by the Emperor, with directions to wear it pendent from his bonnet. He had signalized himself in battle, and received several wounds. His person was perfectly suited for a warrior. He was above the middle size, erect, and uncommonly muscular. In the Ghinese armies, where the bow and arrow are still in use, and generally preferred to fire arms, his activity and strength, as well as his other martial qualities, were highly prized. And, tho he was no boaster, in his deportment was sometimes perceptible an honest conscionsness of his 
Navigation prowess and achievements. But instead of any arrogance Yeligw sea. or roughness in his disposition, good nature was conspicuous in his countenance, and his manners testified his willingness to oblige. He was cheerful and pleasant in his conversation, banishing all reserve, and treating his new friends with the familiarity of old acquaintance.

A third person of high distinction, of a Tartar race, had been sent as principal legate on this occasion by the Emperor, being himself of a Tartar dynasty; but the legate, a man of a haughty disposition, and, besides, very learful of the sea, waited to receive his Excellency after he should get on shore. The others, tho of a different character, were no more than the former much inclined to trust themselves upon that element; but being of Chinese origin, as well as birth, they thought it necessary to be more strict in their obedience, at which they had occasion afterwards to rejoice.

These gentlemen were received on board the Lion with attention and cordiality. Much of the stiffness which generally accompanies a communication through the medium of an interpreter, was removed by the good humour of the parties, and the ardent desire they felt of making out one another's meaning. Their discourse by 110 means partook of the guarded intercourse of strangers suspicious of each other. Sometimes before the explanation was given of the expressions used, the occasion itself suggested what was intended to be said, and 
gesture often came in aid of words. There was, however, so much employment for the Chinese interpreter, that a Yellow sea. trial was now made of the skill of two persons belonging to the Embassy, to whom the Chinese missionaries had endeavoured to communicate some knowledge of their language, ever since they had left Naples together, above a year before. One of these persons applied to this study with the uninterrupted diligence of mature age, but had the mortification of funding that as yet he could scarcely understand a word of what was said to him by these new comers, to whom his pronunciation was equally unintelligible: while the other, a youth, who certainly took less pains, but whose senses were more acute, and whose organs were more flexible, proved already a tolerably good interpreter. Many words, it seems, of the Chinese tongue, of however opposite a signification, frequently differ from each other, in the utterance, only in some slight variation of accent or intonation; and which is susceptible of being more quickly caught, and more accurately rendered by those who learn in early life, than by any who begin to attempt it after being advanced in years. So close is the approximation sometimes in the inflexions of the voice, in uttering Ghinese words of different meanings, that it is not uncommon, even among the natives, in order to avoid mistakes in conversation, to add to the principal terms used, the nearest synonyms in sense, by way of 


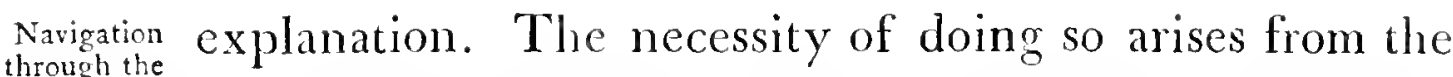
Yellow sea. use of monosyllables only in the Chinese language, which must be less distinct as admitting fewer combinations, as well as from the exclusion of some of the harsher sounds of other nations, among which the difference in the pronunciation of rords is consequently more perceptible.

The two mandarines inquired if the letter brought for the Emperor by the Embassador was translated into Chinese, and requested at any rate to know the purport of it. A compliance with this request was not urged as an etiquette prescribed by the imperial court; nor yet did it appear to have been asked from the indiscreet eagerness of curiosity; but rather was considered as a matter of ordinary course; and which might enable those mandarines more completely to fulfil the object they had in view, of obtaining and conveying to their sovereign every information relating to the Embassy. It was, however, thought more prudent, and perhaps more decent, to reserve the communication of his Majesty's letter, at least until the arrival of the Embassador at the capital; and therefore an answer was given, that the original with the translations of it, were locked up together in a golden box, to be delivered into the Emperor's hands.

Conccming the presents, the mandarines were peculiarly solicitous to inquire; and a list of them was 
formally demanded, to be sent to his Imperial Majesty. Navigation The same demand had, indeed, been made by every Chi- through the nese who had intercourse with the Embassador, or with the Commissioners at Canton, on the subject of the Embassy: and it appeared from the beginning how much curiosity had been excited respecting them. A common catalogue, containing the names of those on board the Hindostan, would not convey any idea of their qualities or intrinsic worth, or indeed be understood by any effort of translation. They would, likewise, suffer by being confounded with the mere curiosities sent usually for sale; which, however expensive, or even ingenious, were more glittering than useful. It was necessary, therefore, to make out, somerwhat in the Oriental style, such a general description of the nature of the articles, now sent, as appeared likely to render them acceptable; measuring their merit by their utility, and endeavouring even to derive some credit from the omission of splendid trifles. It was accordingly prefaced by observing, that " the King of Great Britain, willing to testify his high " esteem and veneration for his Imperial Majesty of " China, by sending an Embassy to him at such a dis" tance, and by choosing an Embassador among the " most distinguished characters of the British domi" nions, wished also that whatever presents he should " send, might be worthy of such a wise and discerning " monarch. Neither their quantity nor their cost could 
Navigation "
tlirough the Yellow sea. "abounding with wealth and treasures of every kind. "Nor would it be becoming to offer trifles of momentary " curiosity, but little use. His Britannic Majesty had " been, therefore, careful to select only such articles as " might denote the progress of science, and of the arts " in Europe, and which might convey some kind of in" formation to the exalted mind of his Imperial Majesty, "or such other articles as might be practically useful. "The intent and spirit accompanying presents, not the " presents themselves, are chiefly of value between so"vereigns."

Some of the articles were described in the following manner.

"The first and principal consists of many parts, " which may be used distinctly, or be connected to"gether, and represents the universe, of which the " earth is but a small portion. This work is the ut" most effort of astronomical science and mechanic art " combined together, that was ever made in Europe. It " shews and imitates, with great clearness and with ma" thematical exactness, the several motions of the earth, " according to the system of European astronomers; " likewise the eccentric or irregular motions of the moon " around it; and of the sun, with the planets which "surround it, as well as the particular system of the "planet, called by Europeans, Jupiter, which has four 
" moons constantly moving about it, as well as belts upon " its surface; and also of the planet Saturn, with its ring

" and moons; together with the eclipses, conjunctions, Yellow sea.

" and oppositions of the heavenly bodies. Another part

" indicates the month, the week, the day, the hour, and "minute, at the time of inspection. This machine is as "simple in its construction, as it is complicated and " wonderful in its effects; nor does any so perfect re" main behind in Europe. It is calculated for above a " thousand years; and will be long a monument of the " respect in which the virtues of his Imperial Majesty " are held in some of the remotest parts of the world.

"With this machine, is immediately connected an" other, of a curious and useful construction, for observ" ing, farther and better than had formerly been done, " distant and minute bodies in the heavens, as they " really move in the great expanse; the result of such " observations demonstrating the exactness with which " those motions are imitated in the machine already de"scribed. Those observations are made, not by look" ing directly at the object, as in common telescopes, in " which the powers of sight are more limited; but by " perceiving, sideways, the reflection of such object upon " mirrors, according to a method invented by a great "philosopher called Newton, and improved by an ex"cellent astronomer called Herschel; and who both " have made such discoveries in science, as to deserve vol. I. 


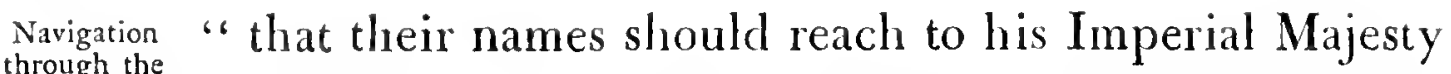
through the " of China. The powers of vision, in particular, have " been extended by their means beyond all former hopes " or calculations.

"As astronomy is not only essentially useful towards " the perfection of geography and navigation, but, from " the greatness of its objects, elevates the mind, and thus " is worthy of the contemplation of sovereigns; and " has, accordingly, attracted the notice of his Imperial "Majesty, who has encouraged the cultivation of that "science, an useful instrument is added for that pur" pose, as it may serve to explain and reconcile the real " motion of the earth, with the apparent motion of the " sun, and other celestial bodies.

"Another article consists of a globe, representing the " heavenly firmament, the ground or general colour " being azure, imitative of the sky; on which ground, " all the fixed stars are placed in their precise relative " positions. The stars are made of gold and silver, in " different tints, and of different magnitudes, according " to the proportional size of which they appear as viewed " from the earth; together with silver lines for the dif" ferent divisions which distinguish the several parts of "the firmament.

"Corresponding to this celestial globe, is one repre"senting the different continents of the earth, with its " seas and islands; distinguishing the possessions of the 
" different sovereigns, capital citics, and great chains of " mountains. It is executed with peculiar care, and com-

"prehends all the discoveries in different parts of the " world, made in the voyages undertaken for that purpose " by order of his Britannic Majesty, together with the " routes of the different ships sent on those expeditions.

"Several packages contain instruments for ascertain" ing time, with all the improvements and elegance of " modern inventions. One of these points out the pe" riods of the new and full, and other phases or changes " of the, moon. The other indicates the state of the air, " and foretells the impending changes in the atmosphere. "A machine is added for removing air, in order to " make, in the vacant space, several curious and extra" ordinary experiments, which prove the importance of " the atmosphere to animal life, and its effects on the " motion of inanimate substances.

"Likewise a machine, pointing out the different " means, or methods, called by Europeans the mecha" nical powers, which assist the natural strength of man " or beast; with contrivances for the exemplification of " those powers, applied to the assistance and comforts of " infirmity or age.

" The next articles consist of several pieces of brass " ordnance used in battles, and howitzer mortars, which " are instruments of annoyance, from whence combus" tible matter is thrown into the towns or fortresses of an 
" enemy. Such instruments were thought likely to be " interesting to so great a warrior and conqueror as his "Imperial Majesty. To these are added other military " weapons, such as muskets, pistols, and sword blades. "These arms, tho richly ornamented, are chiefly valu" able for their useful qualities; the muskets and pistols "for assisting the aim, and assuring the fire, and the "sword blades for cutting through iron without losing " their edge.

"His Britannic Majesty, who is acknowledged by the "rest of Europe to be the first maritime power, and is "truly sovereign of the seas, wished, as a particular " mark of his attention to his Imperial Majesty, to send "some of his largest ships with the present Embassy. "He was however obliged to fix on vessels of a less con" siderable size, on account of the shallows and sands of " the Yellow sea, little known to European navigators; " but he has sent a complete model of the largest British " ship of war, mounting one hundred and ten cannon of " considerable calibre. This model shews every the mi" nutest part of such a stupendous structure. "Specimens are sent likewise of the modes in which " the best British artists work, and render valuable, the " clayey and stony substances found in their own coun" try. Among those specimens are useful and ornamen" tal vases; some imitative of antiquities, and some in " the best modern taste. 
" Several of these articles owe much of their hardness " and beauty to the operation of common or terrestrial

" fire; but a degree of heat, vastly more intense, as well

" as more sudden and astonishing in its effects, is col" lected immediately from the sun, by means of an "instrument, which next follows among the presents. "It consists chiefly of two transparent bodies of glass, " one of a prodigious size for such a material, and "wrought by nice and persevering art into such a "form, and so placed and directed as not only to kindle " into flame matters easily combustible, when exposed " at a particular distance before it, but also to soften and " reduce at once into a powder or a fluid, the hardest "stones, or most refractory metals, of gold, silver, cop" per, iron, or even the new-discovered substance called " platina, or white gold; which platina is more difficult " of fusion in a common fire or furnace, than any of " the metals formerly known in nature. The principal " parts of this machine being as brittle in their compo" sition, as it is powerful, violent, and instantaneous in " its operations, are so difficult to be procured without " defect, and so liable to be broken during the attempts " of the artist to bring them to perfection, that they are " very rarely obtained of a considerable size; and one of " the masses of glass now presented, is much the largest " and most complete that was ever made in Europe.

"In separate cases are packed up the different parts " of two magnificent lustres, or frames of glass, with 
"gold, for containing lights to illuminate the great

Yellow sea. " apartments of a palace: such lustres varying in their "form and effect, according to the disposition of the in " numerable pieces which compose them. In these are "placed circular lamps which diffuse, by a method "lately discovered, a much grander and more vivid " light than art had been enabled to produce before. "Several other packages are added, consisting of a " great number of the productions and manufactures of "Great Britain, particularly in wool and cotton, as well " as in steel and other metals. In such a variety, there " is a chance that some may be found acceptable for " their use, their curiosity, or as objects of comparison " with a few of the great manufactures of his Imperial " Majesty's dominions.

"To the specimens of such articles as were capable of " transportation, are added several representations taken " from nature, of cities, towns, churches, seats, gar"dens, castles, bridges, lakes, volcanos, and antiquities; " likewise of battles by sea and land, dockyards or "places for building ships, horse-races, bull-fighting, " and of most other objects curious or remarkable in the " dominions of his Britannic Majesty, and other parts of " Europe; also, of several of the most eminent persons, " including the royal family of Great Britain ; the repre" sentations themselves being monuments of the arts by " which they are made in their present advanced state." This description, beside being translated into Chinese, 
was likewise very carefully rendered into Latin by Mr. Navigation Hiitner, as his Majesty's letter to the Emperor had been, Yellow sea. in order to afford to the missionaries in his service at Pekin, an opportunity of correcting any error which might have crept into the Chinese translation, the style of writing in that language for the court being familiar only to those who are employed about the palace. This Chinese translation was, however, sufficiently intelligible to Chow-ta-zhin and Van-ta-zhin, to occasion their admiration of its contents. A sufficient number of proper junks was provided to convey the whole across the bar, beyond which it was again necessary to tranship all the articles into vessels of another form and construction; the former being unfit to navigate up the river to the neighbourhood of the capital, and the latter too weak and delicate to resist the surge striking upon the bar, or the occasional violence of the sea without it. Other junks were supplied, likewise, for conveying the persons and baggage of the Embassy from the ships into the river, where vessels fit to navigate upon it were ready to receive them; his Excellency having signified his intention of travelling by water, as the method he understood to be the most convenient.

When the sea junks were all assembled, to the number of about thirty vessels, round the squadron, the whole exhibited a curious contrast, and singular spectacle, of the towering masts and complicated tackling of European 
Navigation through the Yellow sea.

ships, in the midst of the low, simple, and clumsy, but strong and roomy, junks of the Chinese. Each of these was of the burden of about two hundred tons. The hold, or cavity below the upper deck, is divided into about a dozen distinct compartments, by partitions of two-inch plank, and the seams are caulked with a cement of lime, prepared in such a manner as to render them perfectly impervious to water, or, in the marine phrase, water-tight. This cement, Doctor Dinwiddie observes, is composed of lime and oil, with a few scrapings of bamboo; the latter article serving the same purpose as hair in English plaster. This composition, he adds, becomes very tenacious and hard, and will not burn. If, notwithstanding the oil, it possesses that incombustible quality, it is no doubt preferable to pitch, tar, or tallow, none of which are used over the wooden work, or round the ropes of Chinese vessels.

The advantages arising from dividing the holds of those vessels seem to have been well experienced, for the practice is universal throughout China. From hence it sometimes happens, that one merchant has his goods safely conveyed in one division, while those of another suffer considerable damage from a leak in the compartment in which they are placed. A ship may strike against a rock, and yet not sink; for the water, entering by the fracture, will be confined to the division where the injury happens to be sustained; and a shipper of 
wares, who charters several divisions, has a chance, if one of them proves leaky, that those contained in the through the remainder may escape.

To the adoption of a similar plan in European merchantmen, beside the opposition of popular prejudice, and the expence, as well as uncertainty of new experiments, an objection might arise from the reduction it would occasion in the quantity of freight, and the increased difficulty of stowing bulky articles; it remains to be considered how far those objections ought to prevail against the greater security of the vessel, crew, and cargo. At any rate, the objection does not apply to ships of war, in which, to carry very heavy burdens, is not an object of consideration.

Every junk had two large masts, each of which consisted of a single tree, or piece of timber, of a diameter much greater in proportion to its length than that of European masts. Those of China carried each a square sail, generally made of split bamboo, and sometimes of matting, composed of straw or reeds. The junks are nearly of the same flat form at both extremities. At one is a rudder, of a breadth almost equal to that of a London lighter. It is guided by ropes passing from it along each side of the vessel's quarter. Their compassbox is shut up in a small bowl in a part of the ship nearly corresponding to that where it stands in the binnacle of an European vessel. A candle is frequently kept lighted vOL. I. 
Navigation through the Yellow sea.

near it, and a quantity of sand is placed in the bottom of the bowl, in which are stuck some perfumed matches when an offering is intended to be made to the divinity that is supposed to preside over the sea. To that divinity an altar, well stored with trinkets and matches, is erected at the extremity of a very small cabin, round which are the births for the captain and crew, just of sufficient size to contain their persons; each birth is supplied with a mat, by way of bed, and a hard stuffed cushion to lay the head upon. Forty or fifty men were sometimes employed to navigate one junk. They seemed all to take an equal interest, and an equal share in the conduct of the vessel; and it was understood that none of them received fixed wages, but that each had a portion of the profit accruing from the service performed.

Into a sufficient number of those junks the presents and baggage were transhipped, tho in the open sea, without any damage. The weather indeed was fine. The stormy season, however, was approaching: and it was impossible for the squadron to make much stay in its present exposed situation. It had been intended by the East India Company, that as soon as the Hindostan should be discharged by the Embassador at Tien-sing, she should procecd to Canton to take a cargo from thence for Europe, in the usual way of trade. But as she must in her route pass by Chu-san, it was now thought de- 
sirable for her to touch there, in the probability of her procuring a lading home on more advantageous terms than at Canton, if leave should happen to be granted for the purchase, at the former port, of the teas and silks of the neighbouring provinces. On this account, Captain Mackintosh was the more readily allowed by the Embassador to accompany him to Pekin, that he might have the opportunity of soliciting that permission personally from the government; and might, in his way back to join his ship, have perhaps occasion to observe the method of manufacturing the goods he generally carried from China, relative to which the East India Company was desirous of receiving particular information. It was absolutely necessary likewise, before the Embassador should leave the Lion, to determine how to dispose of her while the public business might detain his Excellency on shore. No knowledge had been obtained of a harbour sufficiently secure for her during winter, throughout the gulf of Pekin. It was thought also, that a Chinese port was the least desirable for her to continue long in, as, notwithstanding every care, some accident or difference with the natives might take place to affect the general purpose of the Embassy. The apprehension even of any disturbance might operate on such a government as that of the Chinese, to occasion the premature departure of the Embassador. Nor did Sir Erasmus Gower think it conducive to the health or dis. 
cipline of his men that they should remain, any length of time, inactive. By employing a part of his leisure during the present season in sailing to Japan, with a view to sound the disposition of that court towards a mercantile connection with the English nation, his Excellency might be enabled to determine about going there, agreeably to his instructions, in case there should be a reasonable prospect of public benefit from such a measure; or if Sir Erasmus Gower should find that people persevering in their usual system of exclusion, or that, otherwise, no material advantage was to be derived from any intercourse with them, the information of that commander might save the expence of the Embassy's continuing longer in Asia, for the purpose of such an expedition. Combining these considerations with the general objects of the nission, the Embassador wrote to him agreeably to the powers he had received, that " as it was impossible for the Lion to remain much "longer in her present situation without the bar, which " prevented the entrance of such a vessel into the Pei" ho river, he thought himself bound to state to him "the manner in which he conceived it expedient for " his Majesty's service that she should be employed, " while the business of the Embassy miglit detain him " at the court of Pekin; that it would no doubt be in "the first place necessiry that she should proceed to "the nearest harbour, where she might be made ready 
" for a voyage to some of the principal islands in the "Chinese seas, alter the sick should recover from the Navigation tiveger the " effects of the unwholesome climate on the coasts of "Java and Sumatra; that the commander would pro" bably fix for that purpose on the bays of $\mathrm{Ki}$-san-seu, " or Chu-san, at which places there were small islands "where tents might be conveniently erected in dry " and airy situations, favourable for convalescents, and " where, by direction of the neighbouring mandarines, " he would be able to obtain refreshments of every " kind. His Excellency knew that it was the intention " of the commander to pay for every article received on " board. It was possible, however, that the mandarines "would conceive themselves bound by the general " orders of the Emperor relative to the Embassy, to ac" cept no payment for the supplies afforded to the Lion; " but to charge for them in account with the imperial " treasury, and perhaps not without exaggeration as to "quantity and value; and as it was essential that the " Embassy should appear as little burdensome as pos"sible to the Chinese, he trusted that the commander " would give particular directions, that no provisions or " other articles be received on board, except what were " solely for the general account, as absolutely neces"sary for the ship's use, or the health of the crew; and " that nothing of any kind be allowed to come on board " as presents to individuals. His Excellency understood 
Narigation " that the people of the Lion had hitherto felt little or
through the Yellow sea. " nothing of the scurvy, notwithstanding their long "voyage, which circumstance might be attributed to " the frequent opportunities they had to breathe the air "of land at the several places where they stopped, to " the supplies of fresh provisions which were so often "procured for them by their commander, as well as to " his particular and persevering care for maintaining "cleanliness among the crew, and for expelling all foul " air from every part of the ship.

"While the necessary preparations for sea were go" ing forward, which no doubt the commander could "commit to the attention and ability of his officers, the "Embassador wished to have the satisfaction of his " company with him to Pekin, where, if during his "stay, there should be any opportunity of an audience "of the Emperor, and his Imperial Majesty should be " disposed to ask any questions relative to the British " navy, a person so experienced in it, could give him " the most complete satisfaction. One of the brigs might " remain in the Pei-ho river to convey him to the Lion; " after which it was the Embassador's desire that he " should sail away from the coast of China, so as not to "appear on any part of it, till the month of May en"suing; but to make the best of his way to the port of "Jeddlo, on the southern coast of Japan, where he would "deliver to the Cubo, or temporal sovereign of that 
" country, a letter from his Excellency, to which, com- Navigation " ing to him in so respectable a manner, it was likely yellow sea. " he would pay attention.

"His Excellency had little occasion to point out " what should be the principal objects of notice, either " in the route, or there. Beside all nautical observations " and discoveries, in the importance of which he per"fectly concurred with the commander, the latter would " be able soon to judge whether the people of Japan " entertain, at present, that marked aversion for all fo" reigners, which had been attributed to them formerly, " by persons who might, indeed, be influenced in their " accounts by a desire of deterring the English from " renewing any attempt to trade there. He might per" haps also have an opportunity of finding out how far " their wants or fancies might lead them to purchase " any British manufactures; and whether, in that case, " they had, beside copper, which England produced in " abundance from its own mines, any goods or un" wrought materials that might be exported profitably "from thence for Great Britain. There was indeed " at that moment a strong impediment to any very "minute and particular negotiation with the court of "Japan, as it had not hitherto been found practicable " to procure a Japanese interpreter; but for the present " purpose it would be sufficient to have on board such " persons as understood the two general and common 


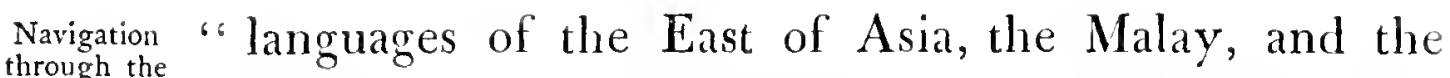
Yrough the "Chinese. As to the former, the native Malay sailor, " already serving in the Lion, who spoke some English, " and the English sailor who spoke the Malay language, " might be of service; and as to the Chinese, his Ex" cellency would, for the public service, give up the " personal convenience he expected to derive from the " attendance of a servant obtained by him from a mis" sionary at Macao, who was conversant in that lan"guage, as well as in the Portugueze. Those three " persons might enable the commander to fulfil the ob"jects in view, not only at Jeddo, but also in other " places to the southward, where he would have occa" sion to go from thence. As soon as he should receive " an answer from the Japanese sovereign, or after waiting " about a fortnight at Jeddo, if he should happen to find " that no answer, either written or verbal, was likely to " be returned to the letter delivered by him, he was to " proceed to Manilla, where he was to hand to the go" vernor of the Philippine islands residing there, a letter "from the Embassador. The harbour of Cavita, at Ma" nilla, was described as perfectly land-locked, and was " convenient as well as safe for ships of the largest size, " in all seasons of the year. Fresh provisions of every " kind were said to be procurable there in great abund" ance, and at reasomable rates. In this harbour, therefore, " the Lion should remain, until the commander found 
" it practicable to sail farther to the southward, which, " from the experience of Mr. Dalrymple, would pro" bably happen about November. During the com-

" mander's continuance at Cavite, he might obtain some " useful information of the present state of the country, "natural and civil, of its trade, and of the character of "the people. It was not unlikely that in the trading "port of Manilla might be found some persons who " had been in Japan, and had acquired a knowledge of " the language of that country. Such a person, con"versant at the same time in any of the European "tongues, or at least in the Chinese or Malay, would "be an acquisition in the event of the Embassador's go" ing to execute his commission at the Japanese court. "And there was no reward not very much exceeding " a reasonable compensation, that he would not will" ingly confer on such a person; and he would there"fore subscribe to the conditions Sir Erasmus Gower " should find it necessary to make, if he should happen " to meet one in the course of his expedition.

"In proceeding to the southward, as soon as might " be, Sir Erasmus would endeavour, beside other nau"tical observations for the improvement of navigation " and geography, to visit the island of Lalutaya, which, " by a manuscript account of an experienced navigator, " subjoined to these instructions, appeared to contain a " very good harbour, and to be in other respects advanrol. I. 
Navigation through the Yellow sea.
" tageously circumstanced. It was laid down in about " ten degrees fifty minutes north latitude, distant about " twenty leagues to the eastward of the long island of "Palawan. It was named in the chart of Faveau's " voyage as reduced by Mr. Dalrymple. The neigh"bouring island of Cuyo was said to abound in all " kinds of provisions.

"From Lalutaya the Embassador wished the com" mander of the Lion to proceed to Magindanao, other" wise called Mindanao; which, tho sometimes reckoned " among the Philippine islands as lying very near them, " was for the most part, if not entirely, independent of "the Spaniards; and its government was generally at "variance with that people.

"The Sultan of Magindanao had on former occa" sions professed himself a friend of the English, and " by way of encouragement to them to trade in his do" minions, he passed to them a grant of the island of "Bonwoot, situated near, and almost opposite, to the " principal port of Magindanao. The commander was "to deliver likewise a letter to that prince from the "Embassador; and, after requesting a speedy answer, " he wals to visit the island of Bonwoot, which was de"scribed as having a convenient harbour. The com" mander's stay at Magindanao need not be more than "a few days, which he would certainly turn to the best "account, for the purpose of obtaining all kinds of in- 
"formation. He would be able there to judge how "far it might be practicable and safe to continue his

"voyage to Gilolo, which, as one of the Moluccas

"from its situation, tho not subject to the Dutch, must " afford matter of much useful knowledge and observa" tion. In the doubt whether he could conveniently " reach so far within the time allotted for the expedi" tion, and in the uncertainty also of the disposition of " the sovereign of that country towards the English, or " any Europeans, the Embassador addressed no letter " there, tho he had, beside special commissions to par" ticular princes, general credentials to treat, in his Ma" jesty's name, with any of the powers in the Chinese " seas; but if the commander should find it convenient "to reach Gilolo, and should discover any inclination "there in favour of the English, he was to announce " his Excellency's intention of visiting that country, if "his stay in Asia would allow it, and of establishing a " connection useful to both nations.

"Either from Gilolo, or immediately from Magin"danao, Sir Erasmus Gower was to proceed to that part " of the large island of Celebes which is not subject to "the Dutch. His former experience at that island " would give him uncommon advantages on the present "occasion, both as to the navigation in the neighbour" hood, and the disposition of the people. The Em"bassador had only to propose, in regard to Celebes, 
Navigation "what already he had mentioned in relation to Gilolo,

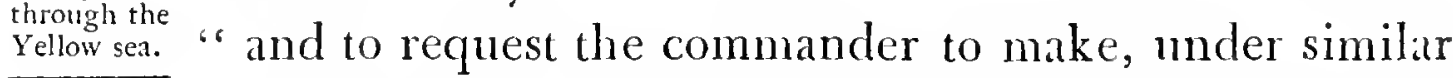
" circumstances, the same declaration of his Excellency's "intentions; and the same also at the island of Borneo, " where he hoped the Lion would be able to stop also, " either at Bangar, Succedana, or at the capital, called, "like the great island itself, Borneo. In Bangar the "English had formerly a factory; and in the city of "Borneo there were still supposed to be some British "subjects, either constantly residing there, or occasion" ally trading to it. Nothing would be more desirable, " or more consistent with the general object of the mis" sion, than any fair and peaceable endeavour to spread " the use of British manufactures throughout every part " of Asia, from whence any valuable return might be " made to Europe, which was eminently the case of "Borneo. The jealousy of the Dutch traders might be " in the way in some parts of that extensive country; " but others might be found where there was less a like" lihood of interlering with them. "The time which visiting so many places would " take up, together with the delays which it might be " nccessary to make in the several ports where the com" mander was thus to stop, would probably bring him " to the vernal equinox, or thereabouts; after which he " should make the best of his way to Macio, where the " Imbassador would expect him as nearly as possible 
"to the beginning of the following May. As no occa" sion was to be omitted which promised any sort of

" utility, or any addition to knowledge; it occurred to

" his Excellency that another and more successful trial " might be made to get into Pulo Lingen, if that place "should be in the Lion's track, on her return to the "northward. The same motives of public benefit and "gratification would have induced him to include in " the route already pointed out, the eastern part of the " island of Formosa (which was said not to belong to " the Chinese), the several smaller islands to the east"ward of Formosa, and the Leoo-keoo islands to the " southward of Corea, were he not afraid of interfering " too much with the other more material parts of the " undertaking; but it would give him additional satis"faction, if it should so happen that the commander " could see and gain information as to those places also."

The Embassador concluded these instructions by observing, that "he had, without reluctance, expressed "his wishes as to the chief objects to be accomplished "by Sir Erasmus Gower, and had guarded them with "few recommendations of precaution, as he was im" pressed with so full a confidence in the prudence and " ability of him to whom they were addressed. He " might be forced, by events which the Embassador " could not foresee, or circumstances of which he was " not aware, to deviate from the route, and the instruc- 
Navigation through the Yellow sea. "tions thus communicated to him, but his Excellency " was persuaded, that he should have occasion to ap" prove of the conduct of Sir Erasmus; and had no "doubt that his time would be usefully employed for "the public service."

Sir Erasmus Gower " had no difficulty in saying, " that on the recovery of his people, or of part of them, " he should be able to visit the different places men" tioned in the Embassador's instructions; that he would " have the bay of Ki-san-seu strictly examined; and "should that place furnish security for the ship, he " would stop there to establish the health of the crew; " if it did not, he conceived it would be necessary for " him to proceed to Chu-san; that a letter would be de" sirable to be obtained from government for him to " those places, that he might be supplied with refresh" ments, and the use of a building for the sick and " convalescents, or, at any rate, a piece of ground on " which tents might be erected for them; that his at" tention to them rendered it incumbent upon him to " decline the proposal, however desirable, of going to "Pekin, that he might continue by them, and imme" diatcly afterwards proceed to fulfil the objects pointed "out to him for the public benefit."

Application was made to the mandarines for the letter which was to secure good treatment for the Lion; and it was promised to be obtained without delay from 
the viceroy of the province. In the mean time, as soon as all the presents and baggage were transhipped, the Embassador and his suite prepared to quit the Lion and through the Hiudostan. Upon this occasion there was a general meeting on board the ships, between those who were to depart from thence, and those who were to remain behind. Every pleasant circumstance occasioned by their having been together, now occupied their minds, and they took an affectionate farewell of each other. On the departure of the Embassador, the crews of the ships, who had indeed been picked men, and had behaved well throughout the voyage, and in consequence had lately received marks of his Excellency's satisfaction, most readily obeyed the orders for manning the yards, as a mark of respect to him, and gave loud cheers, which, together with the firing a salute of many guns from each of the ships, afforded a new spectacle to the Chinese.

The Embassador and gentlemen of the Embassy embarked on the fifth of August, 1793, for the Pei-ho river, on board the Glarence, Jackall, and Endeavour brigs, while the servants, guards, musicians, and other attendants, accompanied the presents and baggage in the junks. Proceeding with a favourable breeze and a spring tide, they crossed the bar in a few hours. The neighbouring coast is so very low as to be scarcely discoverable, at two miles distance, but by means of the build- 
Navigation ings erected on it. Upon the bar, and within it, the through the Yellow sea. water is thick and muddy, altho, outside, and at the Lion's birth, it was remarkably green and clear. This bar was divided into a number of sandy banks, lying in various directions, but so high and so close to each other as to prevent the passage, even of such vessels as the Glarence and Jackall, except at high water. The river immediately within the bar deepened to three or four fathoms; it was there, in width, about five hundred yards, and covered almost entirely with junks, and craft of every kind. On its southern bank, or to the left of the entrance, was a small village called Tung-coo, with a military post, where the troops were drawn up in compliment to the Embassador.

On the idea which had been entertained that he must be anxious to get ashore at the first land, in order to recover from the irksomeness and fatigue of so long a continuance at sea, the junks attending him suddenly let go their anchors here. His Excellency, however, preferred joining immediately the yacht, or accommodation vessel, which was waiting for him a few miles up the river. The situation of Tung-coo was not indeed inviting: the land was low and swampy, and covered, in great measure, with the long and not useless reed, then flowering, called arundo phragmites, generally found in grounds occasionally inundated. The passage from hence, as against the current of the river, was 
necessaily slow. The frequent shoals of this winding stream added also to the delay; when the force of an Navigation adverse current was not overpowered by the wind or through tha tide, the vessels were tracked by human laboul; a sufficient number of Chinese peasants being employed for that purpose. The vessels, in their progress, soon passed another village called See-coo, and reached the same evening the town of Ta-coo. The teminating syllable of the names of all those places being the same, and intimating in the Chinese language their proximity to the river's mouth, as the different initiating syllables do, that the first is to the east, the second to the west, and that the last is of considerable size.

Many of the louses in these places, as well as those which were thickly interspersed between them upon the river's banks, were little better than huts with mud walls and thatched roofs. A few buildings were large, elevated, painted, and ornamented like the dwellings of opulence, but searcely any which indicated the existence of middle ranks, or the multiplied gradations existing elsewhere, between abundant wealth and absolute indigence. Among the inhabitants who appeared along the river were some women, as alert as if their feet had not been cramped. It is said, indeed, that this practice is now less frequent than formerly, at least among the lower sort, in the northern provinces. They all wear their hair, which is universally black, and VOL. I. 
Navigation strong, neatly braided, and fastened with a bodkin upon
through the yellow sea. the crown of the head. The young children were mostly naked. The men in general were well-looking, well-limbed, robust, and muscular. The eagerness of curiosity animated and perhaps improved their countenances; and they were assembled in such multitudes, that it might, with the poet, be exclaimed,

" How many goodly creatures are there here!" 


UNIVERSITY OF CILIFORNIA LHBRARY

Los Angeles

This book is DUC on the last date stamped below.

1

University of California

SOUTHERN REGIONAL LIBRARY FACILITY

405 Hilgard Avenue, Los Angeles, library

Return this material to the librom which it was borrowed.
from 


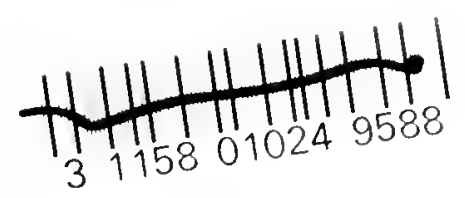


thition 